\title{
Anodic electrochemistry of mono- and dinuclear aminophenylferrocene and diphenylaminoferrocene complexes
}

Article

Accepted Version

Zhang, M.-X., Zhang, J., Yin, J., Hartl, F. and Liu, S. H. (2018) Anodic electrochemistry of mono- and dinuclear aminophenylferrocene and diphenylaminoferrocene complexes. Dalton Transactions, 47 (17). pp. 6112-6123. ISSN 1364-5447 doi: https://doi.org/10.1039/c8dt00584b Available at https://centaur.reading.ac.uk/79077/

It is advisable to refer to the publisher's version if you intend to cite from the work. See Guidance on citing.

To link to this article DOI: http://dx.doi.org/10.1039/c8dt00584b

Publisher: Royal Society of Chemistry

All outputs in CentAUR are protected by Intellectual Property Rights law, including copyright law. Copyright and IPR is retained by the creators or other copyright holders. Terms and conditions for use of this material are defined in the End User Agreement.

www.reading.ac.uk/centaur 
Central Archive at the University of Reading

Reading's research outputs online 


\title{
Anodic Electrochemistry of Mono- and Dinuclear Aminophenylferrocene and Diphenylaminoferrocene Complexes
}

\author{
Ming-Xing Zhang, ${ }^{\dagger, \S}$ Jing Zhang, ${ }^{\dagger, \pi}$ Jun Yin, ${ }^{\dagger}$ František Hartl, ${ }^{*}{ }^{\star}$ Sheng Hua Liu* ${ }^{* \dagger}$ \\ ${ }^{\dagger}$ Key Laboratory of Pesticide and Chemical Biology, Ministry of Education, College \\ of Chemistry, Central China Normal University, Wuhan 430079, P.R. China \\ " College of Chemistry, The Hong Kong University of Science and Technology, Clear \\ Water Bay, Kowloon, Hong Kong \\ ${ }^{\ddagger}$ Department of Chemistry, University of Reading, Whiteknights, Reading RG6 6AD, \\ $U K$ \\ ${ }^{\S}$ These authors have contributed equally to this work.
}

\begin{abstract}
Two related three-membered series of nonlinear aminophenylferrocene and diphenylaminoferrocene complexes were prepared and characterized by ${ }^{1} \mathrm{H}$ and ${ }^{13} \mathrm{C}$ NMR spectroscopy. The first series consists of 4-(diphenylamino)phenylferrocene (TPA-Fc, 1a), its dimethoxy-substituted tetraphenylphenylenediamine derivative (M2TPPD-Fc, 1c), and the triphenylamine-bridged bis(ferrocenyl) complex (Fc-TPA-Fc, 1b). The second series involves bis(4-methoxyphenyl)aminoferrocene (M2DPA-Fc, 1d), 4-methoxyphenylaminoferrocene (MPA-Fc) with $N$-phenyl-appended terminal TPA (1e), and the corresponding bis(MPA-Fc) complex with bridging TPA (1f). The structure of complex 1d was further confirmed by single crystal X-ray diffraction. Combined investigations, based on anodic voltammetry, UV-vis-NIR spectroelectrochemistry and density functional theory (DFT) calculations, were conducted to illustrate the influence of the integration of multiple redox-active components on the sequential oxidation of these complexes. The first anodic steps in
\end{abstract}


1a-1f are localized preferentially on the ferrocenyl units, followed by oxidation of the TPA or TPPD moieties (absent in 1d). Irreversible oxidation of the ferrocene-appended strong donor DPA/MPA units in 1d-1f terminates the anodic series. The one-electron oxidation of the triphenylamine-bridged diferrocenyl (1b) and bis(phenylaminoferrocenyl) (1f) complexes triggers their facile redox disproportionation to dicationic bis(ferrocenium) products.

Keywords: Arylamine bridge; Ferrocene; Oxidation; Spectroelectrochemistry; DFT Calculations

\section{Introduction}

Ferrocene (Fc) and triphenylamine (TPA) have been considered as ideal redox centers to study the intramolecular electron transfer processes in mixed-valence (MV) systems due to the favorable reversibility of their anodic reactions and stability of the oxidized forms. ${ }^{1-4}$ In the realm of MV species, numerous studies focused in the past decades on $\pi$-conjugated bridging ligands, such as heterocycles, oligoene, oligoyne, phenylene, phenylene-yne, thienyl ethynyl, and oligoacene units. ${ }^{5,6}$ However, studies of the MV behavior with compounds featuring the TPA unit as the non-innocent bridging ligand, and ferrocene as the terminal redox-active center, are relatively limited, ${ }^{4 a, 7}$ let alone the scarcer diphenylaminoferrocene (DPA-Fc) systems, where the donor nitrogen is directly bound to one of the ferrocene cyclopentadienyl rings, both constituting "electron-rich" units. ${ }^{8}$ According to our survey, the DPA-Fc systems appending diphenylamino groups to the ferrocene core are excellent $p$-type materials with good electrochemical stability and high hole mobility. ${ }^{89}$ These excellent properties are most likely due to the incorporation of the DPA groups that enhance intermolecular interactions and thus increase the hole transport properties and stability of the system. Pertinent reports on the DPA-Fc complexes however mainly focus on the exploration of synthetic methods to prepare some simple systems, ${ }^{8,9}$ and detailed studies on their electronic properties, or involvement of more complex species 
featuring multiple redox-active components, are sporadic. From this perspective, an interesting research aspect is a comparative exploration of a series of similar phenylamino-ferrocene systems to clarify their electron-transfer nature and further facilitate their applications. Based on this point, we have been interested in exploring a/ the electronic properties of the linked mono- and dinuclear TPA-ferrocene systems (1a, 1b), b/ the redox-asymmetry of dimethoxy-substituted tetraphenylphenylenediamino-ferrocene (M2TPPD-Fc, 1c), and c/ the methoxy-substituted DPA-Fc derivatives (1d-1f) with TPA in the terminal (1e) and bridging (1f) positions, see Chart 1. The synthetic routes toward 1a-1f featuring the integrated multiple redox-active components are based on a range of Pd-catalyzed coupling reactions (see Scheme 1). We have aimed to elucidate how the redox, spectroscopic, and electronic properties of the two investigated ferrocenyl series are affected by the variation of the ancillary redox-active oligoamino groups. The data sets evaluated in the discussion have been obtained by using controlled-potential voltammetry and UV-vis-NIR spectroelectrochemistry combined with density functional theory calculations.

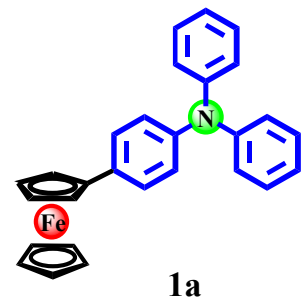

$1 \mathbf{a}$

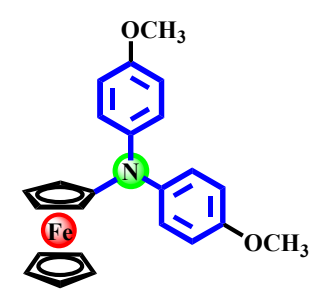

$1 d$

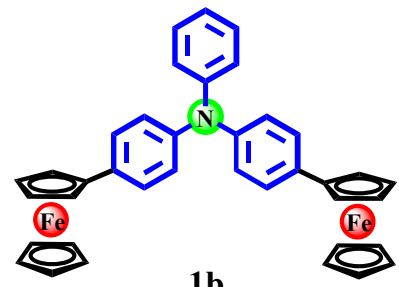

$1 \mathbf{b}$

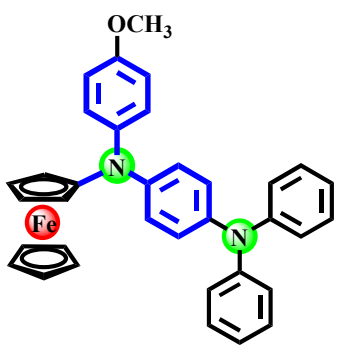

1e
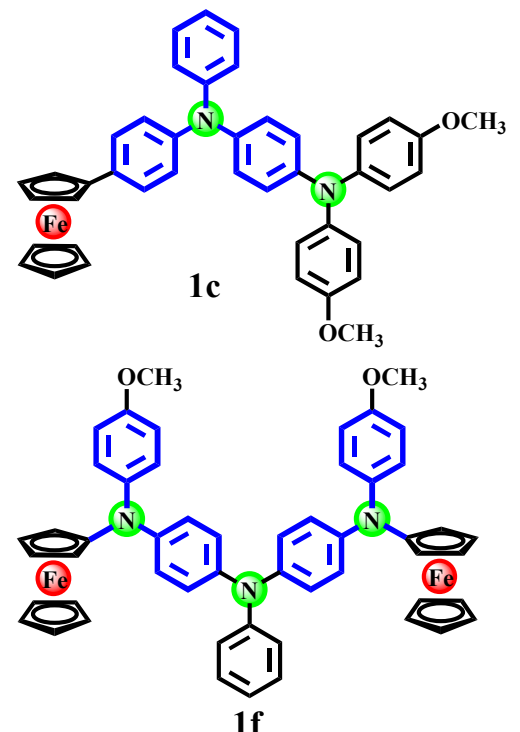

1f

Chart 1. Studied 4-(diphenylamino)phenyl-ferrocene series with TPA (1a, 1b) and M2TPPD (1c), and diphenylaminoferrocene (DPA-Fc) derivatives (1d-1f). 


\section{Results and Discussion}

\section{Syntheses and Characterization}

The synthetic routes to complexes $\mathbf{1 a}-\mathbf{1 f}$ are outlined in Scheme 1. The precursors $2 \mathbf{c}, \mathbf{2 e}$ and $\mathbf{2 f}$ were obtained in moderate yields ranging from $40 \%$ to $70 \%$, by having exploited Pd-catalyzed Buchwald-Hartwig coupling reactions of 4-bromophenylaniline (2a) and 4-bromo- $N$-(4-bromophenyl)- $N$-phenylaniline (2b) with bis(4-methoxyphenyl)amine, and aminoferrocene (3d). Subsequently, bromo-substituted arylamine precursors $\mathbf{2 a - 2 c}$ were reacted with ferrocenylboronic acid by the Pd-catalyzed Suzuki-Miyaura coupling to obtain the corresponding target complexes, 1a-1c, respectively. The DPA-Fc series, 1d-1f, was synthesized using the Pd-catalyzed Buchwald-Hartwig coupling between the arylaminoferrocene precursors, 2d-2f, and 1-bromo-4-methoxybenzene. Notably, no apparent differences have been observed in comparative ${ }^{1} \mathrm{H}$ NMR spectra of complexes $\mathbf{1 a}-\mathbf{1 f}$, viz. the $-\mathrm{OCH}_{3}$ and Cp signals (see Supporting Information). 


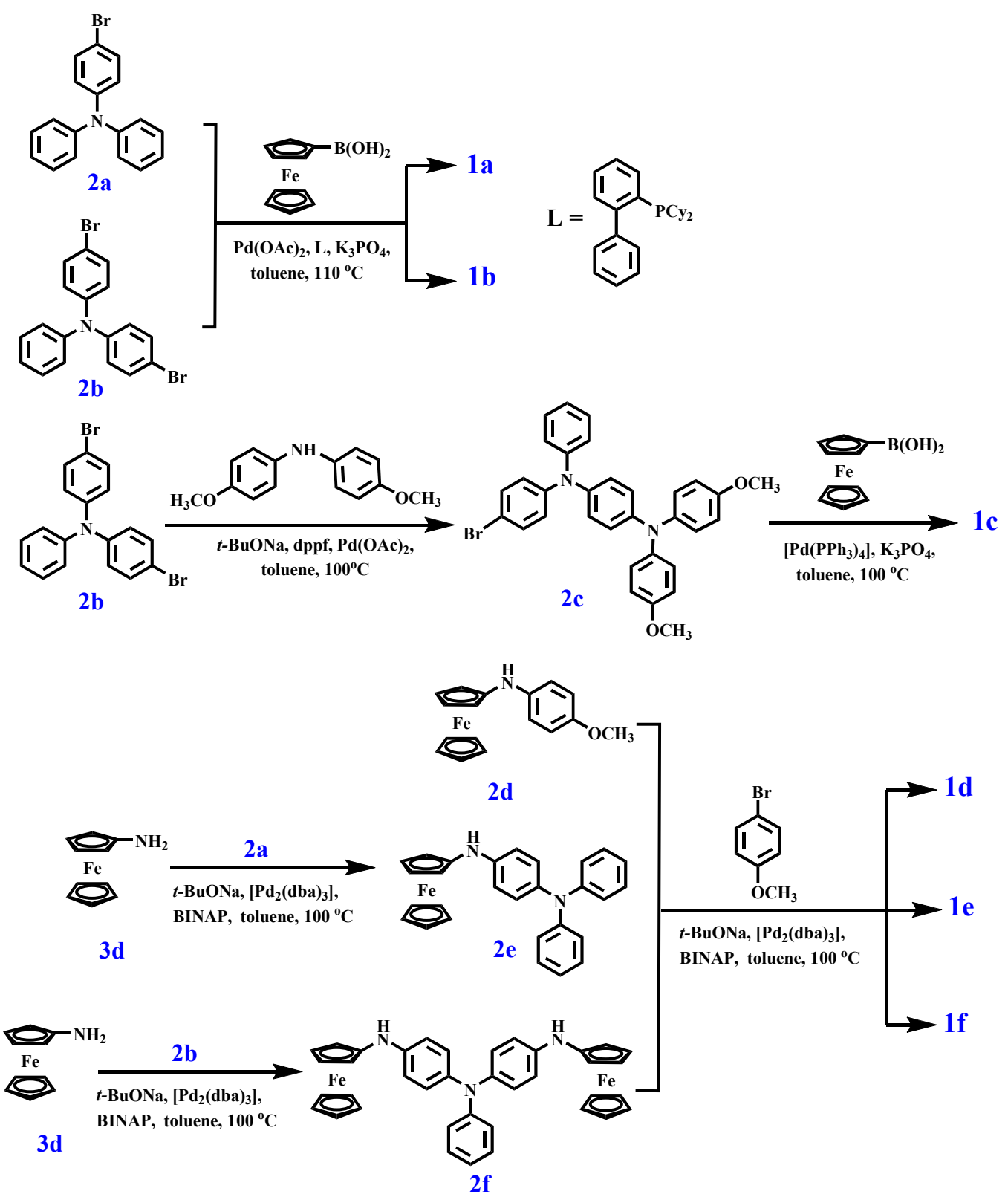

Scheme 1. Synthetic routes to complexes 1a-1f.

\section{X-ray Crystallography}

The molecular structure of solid complex 1d (Figure 1) has been resolved by single crystal X-ray diffraction. Suitable crystals of the complex were grown by slow evaporation of its dichloromethane solution at room temperature. Pertinent diffraction parameters are given in Tables 1 and S1 (see the Supporting Information). The pairs 
of C1(ferrocenyl)-N1-C18, C1(ferrocenyl)-N1-C11 and C11-N1-C18 angles are $124.0(2)^{\circ}, 114.3(2)^{\circ}$ and $117.4(2)^{\circ}$, respectively. Notably, some conjugation exists between the nitrogen atom and ferrocene, as indicated by the shorter $\mathrm{C} 1-\mathrm{N} 1$ bond of 1.411 (3) A compared to the N1-C11 and N1-C18 bonds of 1.439 (3), and 1.425 (3) $\AA$, respectively, as observed for other substituted triphenylamine systems. ${ }^{8 c, 10-13}$ The above trend and crystal data are consistent with the corresponding theoretical results obtained for the DFT (G09-B3LYP)-optimized structure presented in Table 1.

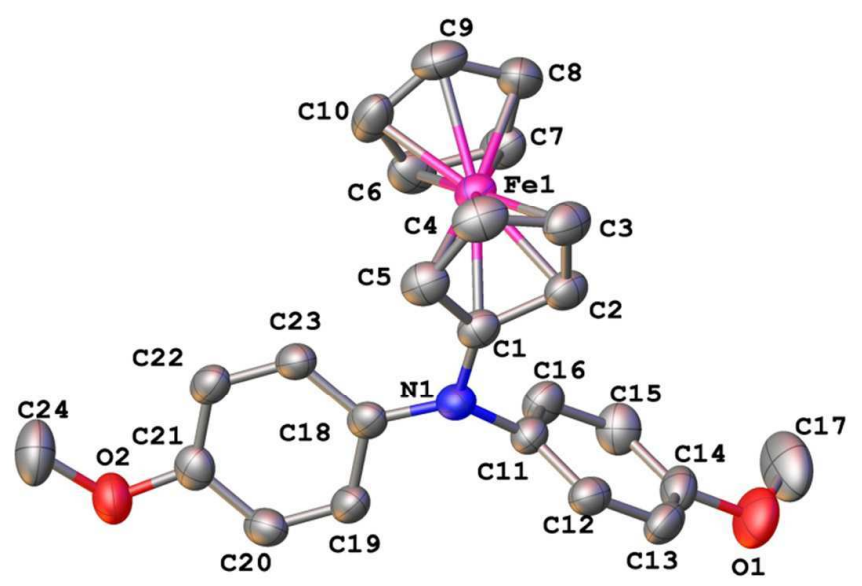

Figure 1. Thermal-ellipsoid plot of the X-ray structure of complex 1d (50\% probability). Hydrogen atoms have been omitted for clarity.

Table 1. Selected bond lengths $(\AA)$ and angles (deg) in the crystal structure and DFT (G09-B3LYP)-optimized structure of complex $1 \mathbf{d}$.

\begin{tabular}{ccc}
\hline Parameter & Crystal & Calculated \\
\hline $\mathrm{C} 1-\mathrm{C} 2$ & $1.422(4)$ & 1.435 \\
$\mathrm{C} 2-\mathrm{C} 3$ & $1.416(4)$ & 1.430 \\
$\mathrm{C} 3-\mathrm{C} 4$ & $1.405(4)$ & 1.425 \\
$\mathrm{C} 4-\mathrm{C} 5$ & $1.421(4)$ & 1.430 \\
$\mathrm{C} 1-\mathrm{N} 1$ & $1.411(3)$ & 1.402 \\
$\mathrm{~N} 1-\mathrm{C} 11$ & $1.439(3)$ & 1.429 \\
$\mathrm{~N} 1-\mathrm{C} 18$ & $1.425(3)$ & 1.424 \\
$\mathrm{C} 11-\mathrm{C} 12$ & $1.383(3)$ & 1.398 \\
$\mathrm{C} 12-\mathrm{C} 13$ & $1.376(4)$ & 1.397 \\
$\mathrm{C} 13-\mathrm{C} 14$ & $1.378(4)$ & 1.399 \\
$\mathrm{C} 14-\mathrm{O} 1$ & $1.372(3)$ & 1.366 \\
$\mathrm{O} 1-\mathrm{C} 17$ & $1.408(4)$ & 1.417 \\
& 6 &
\end{tabular}




\begin{tabular}{ccc}
$\mathrm{C} 1-\mathrm{Fe} 1$ & $2.072(2)$ & 2.163 \\
$\mathrm{C} 1-\mathrm{N} 1-\mathrm{C} 11$ & $114.3(2)$ & 119.1 \\
$\mathrm{C} 1-\mathrm{N} 1-\mathrm{C} 18$ & $124.0(2)$ & 122.5 \\
\hline
\end{tabular}

\section{Electrochemical Properties}

The anodic behavior of complexes 1a-1f was investigated by cyclic voltammetry (CV) and square-wave voltammetry (SWV) in deaerated dichloromethane containing $10^{-1} \mathrm{M} n-\mathrm{Bu}_{4} \mathrm{NPF}_{6}$ as the supporting electrolyte (Figure 2). The relevant electrochemical data are summarized in Table 2.

The TPA-bridged bis(ferrocenyl) compound (1b) exhibits two reversible anodic waves, similarly to the voltammetric response of related monoferrocenyl-TPA (1a). However, the first anodic wave of $\mathbf{1 b}$ is relatively broad, consisting of two poorly resolved one-electron steps. The reference anodic potentials of free ferrocene and TPA (Figure S1, top) indicate that the initial oxidation process of both $\mathbf{1 a}$ and $\mathbf{1 b}$ is associated with the ferrocenyl units. The small separation of ca. $80 \mathrm{mV}$ between the two oxidations encompassed in the first anodic wave of $\mathbf{1 b}$ has been estimated as described in the literature. ${ }^{14}$ The two Fe(II) centers in $\mathbf{1 b}$ are oxidized nearly synchronously, reflecting a very weak electron communication between the ferrocenyl termini. This localized behavior closely resembles the initial two-electron oxidation reported for a TPA-bridged diethynyl diiron complex. ${ }^{4 a}$

The anodic voltammetric response of the M2TPPD-ferrocene complex, 1c, shows three reversible one-electron waves. We presume that only the first anodic step belongs to the oxidation of the ferrocenyl unit while the two subsequent oxidation processes are diamine-based, in agreement with outcomes of UV-vis-NIR spectroelectrochemistry and DFT calculations (vide infra). The second and third oxidation potentials of $\mathbf{1 c}$ are positively shifted compared to the symmetric methoxy-substituted TPPD (M4TPPD) ${ }^{4 \mathrm{~g}}$ reference (Figure S1, bottom), reflecting the presence of the oxidized ferrocenium unit in $[\mathbf{1 c}]^{+}$.

The DPA-Fc series, 1d-1f, is characterized by the first anodic process shifted negatively on the $\mathrm{Fc} / \mathrm{Fc}^{+}$potential scale to ca. $-0.30 \mathrm{~V}$, which corresponds to the 
oxidation of the $\mathrm{Fe}(\mathrm{II})$ centers as reported $^{8 \mathrm{c}}$ for (di-p-tolylamino)ferrocene. The negative potential shifts compared to 1a-1c reflect the donor capacity of the diphenylamino (DPA) substituent. Comparison with the literature ${ }^{8 \mathrm{c}}$ also facilitates the assignment of the irreversible anodic waves of complexes $\mathbf{1 d - 1 f}$ around $-0.8 \mathrm{~V}$ to the oxidation of DPA, generating a reactive $\mathrm{Fe}(\mathrm{III}) \mathrm{Cp}$-aminium diradical site in $[\mathbf{1 d}]^{2+}$. The preceding one-electron anodic steps seen in the voltammetric responses of $1 \mathbf{e}$ and 1f around $0.45 \mathrm{~V}$ correspond to the reversible oxidation of terminal and bridging TPA, respectively, being shifted less positively compared to $\mathbf{1 a}$ and $\mathbf{1 b}$ due to the donor DPA separating them from the pre-oxidized ferrocenium termini. This assignment is in line with the roughly $2: 1$ ratio of the anodic currents marking the initial ferrocene-based and subsequent TPA-based oxidations of dinuclear 1f (Figure 2). In summary, the anodic behavior of the ferrocenyl, DPA and TPA segments in 1d-1f can be classified as largely independent, with Cp-linked DPA acting as an effective donor substituent.

Table 2. Electrochemical data for complexes $\mathbf{1 a}-\mathbf{1 f}{ }^{a}$

\begin{tabular}{cccccc}
\hline \multirow{2}{*}{ Complex } & $E_{1 / 2}(1) / \mathrm{V}$ & $E_{1 / 2}(2) / \mathrm{V}$ & $E_{1 / 2}(3) / \mathrm{V}$ & $E_{1 / 2}(4) / \mathrm{V}$ & $E_{\mathrm{p}, \mathrm{a}}(5)(\mathrm{V})$ \\
& $\left(\Delta E_{\mathrm{p}}\right) / \mathrm{mV}$ & $\left(\Delta E_{\mathrm{p}}\right) / \mathrm{mV}$ & $\left(\Delta E_{\mathrm{p}}\right) / \mathrm{mV}$ & $\left(\Delta E_{\mathrm{p}}\right) / \mathrm{mV}$ & $b$ \\
\hline $\mathbf{1 a}$ & $-0.06(75)$ & -- & $0.60(80)$ & -- & -- \\
$\mathbf{1 b}$ & $-0.08^{c}$ & $-0.00^{c}$ & $0.67(70)$ & -- & -- \\
$\mathbf{1 c}$ & $0.06(60)$ & -- & $0.21(60)$ & $0.65(85)$ & -- \\
$\mathbf{1 d}$ & $-0.32(75)$ & -- & -- & -- & 0.77 \\
$\mathbf{1 e}$ & $-0.32(70)$ & -- & $0.45(70)$ & -- & 0.84 \\
$\mathbf{1 f}$ & $-0.33^{d}$ & $-0.33^{d}$ & $0.49(65)$ & -- & 0.83 \\
TPA & -- & -- & $0.54(90)$ & -- & -- \\
M4TPPD $^{4 \mathrm{~g}}$ & -- & -- & -0.06 & 0.45 & -- \\
\hline
\end{tabular}

${ }^{a}$ The anodic potentials and $\Delta E_{\mathrm{p}}$ values are referenced against the standard ferrocene/ferrocenium $\left(\mathrm{Fc} / \mathrm{Fc}^{+}\right)$redox couple. Under the experimental conditions used in this work, $E_{1 / 2}\left(\mathrm{Fc} / \mathrm{Fc}^{+}\right)=+0.49$ $\mathrm{V}$ vs $\mathrm{Ag} / \mathrm{Ag}^{+} .{ }^{b}$ Irreversible anodic wave. ${ }^{c}$ Based on the evaluation procedure described in ref. ${ }^{14}$ The measured $E_{\mathrm{p}}$ value (SWV, Figure 2) was $-0.8 \mathrm{~V}$ and the bandwidth was $130 \mathrm{mV}$. ${ }^{d}$ Unresolved two-electron anodic wave $\left(\Delta E_{1 / 2}<50 \mathrm{mV}\right)$. 


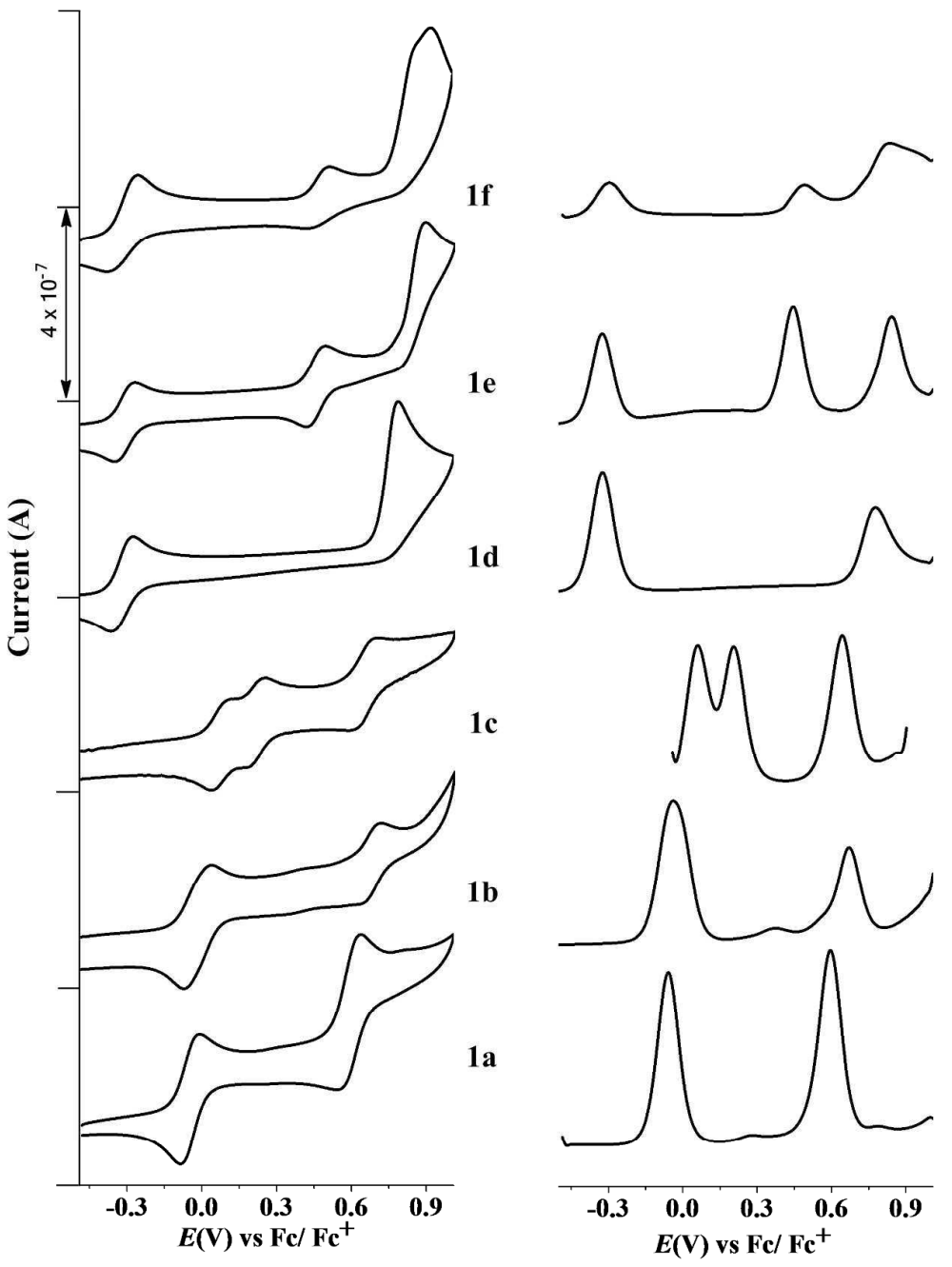

Figure 2. Left: cyclic voltammograms (CV) of complexes 1a-1f in $\mathrm{CH}_{2} \mathrm{Cl}_{2} / n-\mathrm{Bu}_{4} \mathrm{NPF}_{6}$ at $v=50$ $\mathrm{mV} \mathrm{s}^{-1}$. Right: corresponding square-wave voltammograms (SWV) of complexes 1a-1f at $f=10$ $\mathrm{Hz}$ and $t_{\mathrm{p}}=25 \mathrm{mV}$. The curtailed two-anodic-step CV of $\mathbf{1 f}$ is shown separately in Figure S2 (Supporting Information).

\section{UV-vis-NIR Spectroelectrochemistry}

UV-vis-NIR electronic absorption spectra of complexes 1a-1f in their different oxidation states were recorded by means of rapid in situ spectroelectrochemistry, as shown in Figures 3-5, and in Supporting Information, Figures S3-S6. The relevant wavenumbers and molar absorptivity at the absorption maxima are collected in Table 3. 
Smooth oxidation of (diphenylamino)phenylferrocene 1a to stable cationic species $[\mathbf{1 a}]^{+}$was accompanied by the appearance of two intense absorption bands between 25000 and $15000 \mathrm{~cm}^{-1}$ and a weaker NIR absorption around $7500 \mathrm{~cm}^{-1}$, along with a blue shift of the strong UV absorption (Figure 3, top). Not surprisingly, very similar changes in the electronic absorption were encountered during the initial two-electron oxidation of dinuclear $\mathbf{1 b}$ (Figure S3). The mixed-valence intermediate, $[\mathbf{1 b}]^{+}$, which is thermodynamically forced to disproportionate, appears in the potential-dependent spectral profile to absorb in the visible-NIR region at a slightly lower energy than the ultimate bis(ferrocenium) product, $[\mathbf{1 b}]^{2+}$. The subsequent oxidation of terminal TPA in $[\mathbf{1 a}]^{+}$(Figure 3 , bottom) and bridging TPA in $[\mathbf{1 b}]^{2+}$ was hard to compare due to poor solubility of $[\mathbf{1 b}]^{3+}$.

The products of the well-resolved stepwise one-electron oxidation of $1 \mathbf{c}$ to $[\mathbf{1 c}]^{3+}$ could be assigned straightforwardly with the aid of the spectrolectroelectrochemical monitoring. The second and third anodic steps (Figure 4, middle and bottom spectra, respectively) reside on the ancillary diamine group, as revealed by the very similar spectral changes accompanying oxidation of reference $\mathrm{M} \mathrm{TTPD}{ }^{4 \mathrm{~g}}$ to the corresponding mono- and dianion (Figure S4). The initial anodic conversion of 1c to $[\mathbf{1 c}]^{+}$therefore involves the ferrocenyl Fe(II) center, similar to 1a. Accordingly, both $[\mathbf{1 a}]^{+}$and $[\mathbf{1 c}]^{+}$exhibit three pronounced absorption bands in the visible-NIR spectral region (Table 3), which can be assigned to the same kind of charge transfer electronic transitions (Table 4 in the following DFT section).

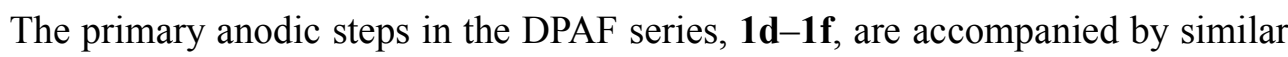
absorption changes in the visible-NIR region as encountered for the oxidation of 1a to $[\mathbf{1 a}]^{+}$, or dinuclear $\mathbf{1 b}$ to $[\mathbf{1 b}]^{2+}$. Thus, also $[\mathbf{1 d}]^{+}$(Figure S5), $[\mathbf{1 e}]^{+}$(Figure 5, top) and dinuclear $[\mathbf{1 f}]^{2+}$ (Figure S6) feature a low-lying weak absorption band between $10000-7000 \mathrm{~cm}^{-1}$ and a more intense one between $22000-20000 \mathrm{~cm}^{-1}$, in line with the generation of the aminoferrocenium moiety. The subsequent reversible oxidation of $[\mathbf{1 e}]^{+}$to $[\mathbf{1 e}]^{2+}$ (Figure 5 , bottom) involves admittedly the terminal TPA unit, the product resembling $[1 \mathbf{a}]^{2+}$ (Figure 3 , bottom) by the diminished NIR absorption and slightly blue-shifted absorption in the green spectral region. 
Table 3. UV-vis-NIR electronic absorption of complexes 1a-1f and their stable oxidized forms ${ }^{a}$ in dichloromethane $/ n-\mathrm{Bu}_{4} \mathrm{NPF}_{6}$.

\begin{tabular}{|c|c|}
\hline Complex & $v_{\max }\left(\mathrm{cm}^{-1}\right)\left(\varepsilon_{\max }\left(\mathrm{dm}^{3} \mathrm{~mol}^{-1} \mathrm{~cm}^{-1}\right)\right)$ \\
\hline $1 \mathbf{a}$ & $31330(20536)$ \\
\hline$[\mathbf{1} \mathbf{a}]^{+}$ & 33620 (20880), 23970 (5040), 19250 (7870), 7740 (3050) \\
\hline$[\mathbf{1 a}]^{2+}$ & $33690,19540,13680^{b}$ \\
\hline $1 \mathbf{b}$ & $30180(39220)$ \\
\hline$[\mathbf{1 b}]^{2+}$ & 33230 (38510), 24390 (11370), 19450 (17260), 8140 (7460) \\
\hline $1 \mathrm{c}$ & $30190(37800)$ \\
\hline$[\mathbf{1 c}]^{+}$ & $33790,23530,17280,10220^{c}, 6680$ \\
\hline$[\mathbf{1 c}]^{2+}$ & 23970 (21380), 16460 (7120), 9960 (26200) \\
\hline$[1 \mathrm{c}]^{3+}$ & $13800(37920)$ \\
\hline M4TPPD $^{d}$ & $32100(13420)$ \\
\hline$[\mathrm{M} 4 \mathrm{TPPD}]^{+d}$ & 24150 (7180), 16950 (2210), $10360(8110)$ \\
\hline$[\mathrm{M} 4 \mathrm{TPPD}]^{2+d}$ & $14410(24160)$ \\
\hline $1 d$ & $35200(21360), 21700(5270)$ \\
\hline$[\mathbf{1 d}]^{+}$ & 35270 (23930), 27700 (8330), 21450 (7840), 19500 (sh), 9280 (2210) \\
\hline $1 \mathrm{e}$ & $33410(39360)$ \\
\hline$[1 \mathbf{e}]^{+}$ & 32790 (43130), 20310 (7050), $8510(2290)$ \\
\hline$[1 \mathbf{e}]^{2+}$ & 33340 (38510), 20990 (6910) \\
\hline 1f & $31140(21750)$ \\
\hline$[\mathbf{1 f}]^{2+}$ & 33750 (18880), 20920 (2980), 8840 (1090) \\
\hline
\end{tabular}

${ }^{a}$ The spectroelectrochemical results obtained for TPA-oxidized dinuclear species $[\mathbf{1 b}]^{3+}$ and $[\mathbf{1 f}]^{3+}$ were affected by low solubility of the trications in the electrolyte used, and, therefore, are not presented here. ${ }^{b}$ The molar absorptivity of $[\mathbf{1 a}]^{2+}$ was not determined due to low-solubility issues at the end of the anodic electrolysis. ${ }^{c}$ This absorption band most likely belongs to $[\mathbf{1} \mathbf{c}]^{2+}$ generated by partial redox disproportionation during the thin-layer electrolysis. The molar absorptivity of $[\mathbf{1 c}]^{+}$is not reported here. ${ }^{d}$ Ref. ${ }^{4 \mathrm{~g}}$. 

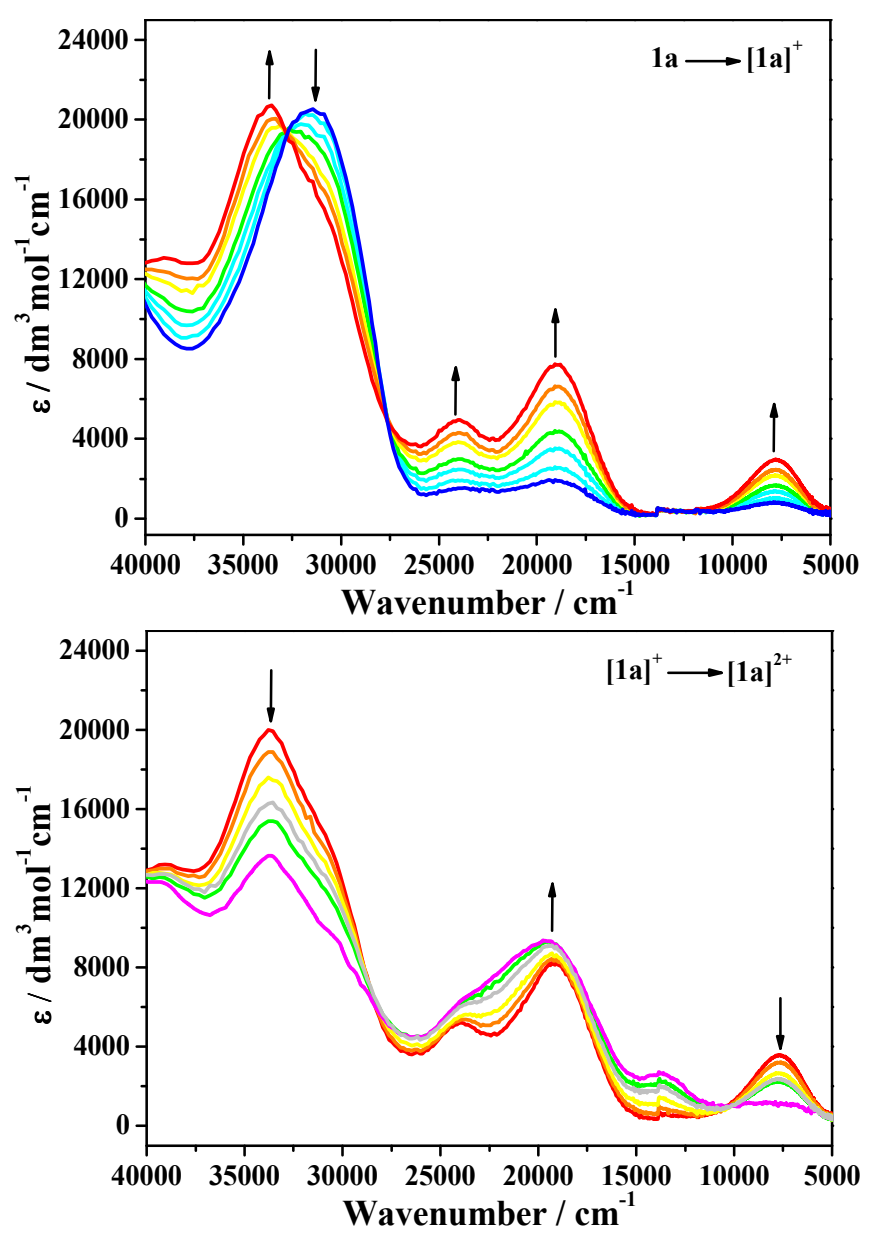

Figure 3. Changes in UV-vis-NIR absorption spectra recorded during the oxidation of complex 1a to $[\mathbf{1 a}]^{+}$(top) and $[\mathbf{1 a}]^{2+}$ (bottom) in $\mathrm{CH}_{2} \mathrm{Cl}_{2} / 10^{-1} \mathrm{M} n-\mathrm{Bu}_{4} \mathrm{NPF}_{6}$ at $298 \mathrm{~K}$ within an OTTLE cell. 

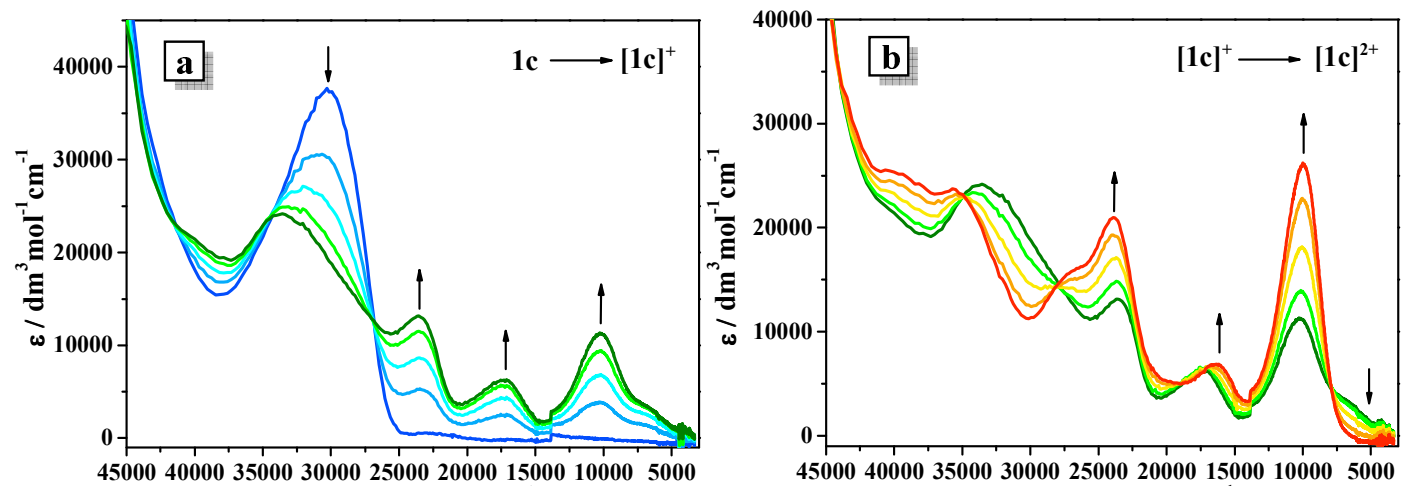
Wavenumber $/ \mathrm{cm}^{-1}$ Wavenumber $/ \mathbf{c m}^{-1}$

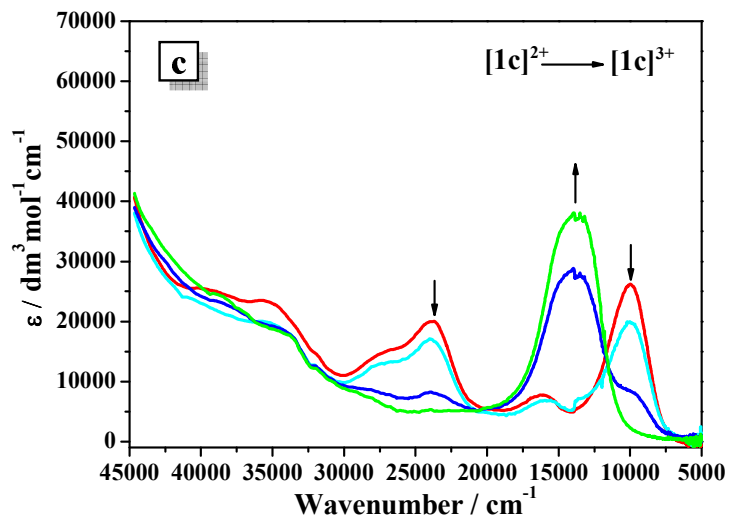

Figure 4. Changes in UV-vis-NIR absorption spectra recorded during the oxidation of complex 1c to $[\mathbf{1 c}]^{+}$(a), $[\mathbf{1 c}]^{2+}$ (b) and $[\mathbf{1 c}]^{3+}$ (c) in $\mathrm{CH}_{2} \mathrm{Cl}_{2} / 10^{-1} \mathrm{M} n-\mathrm{Bu}_{4} \mathrm{NPF}_{6}$ at $298 \mathrm{~K}$ within an OTTLE cell. 

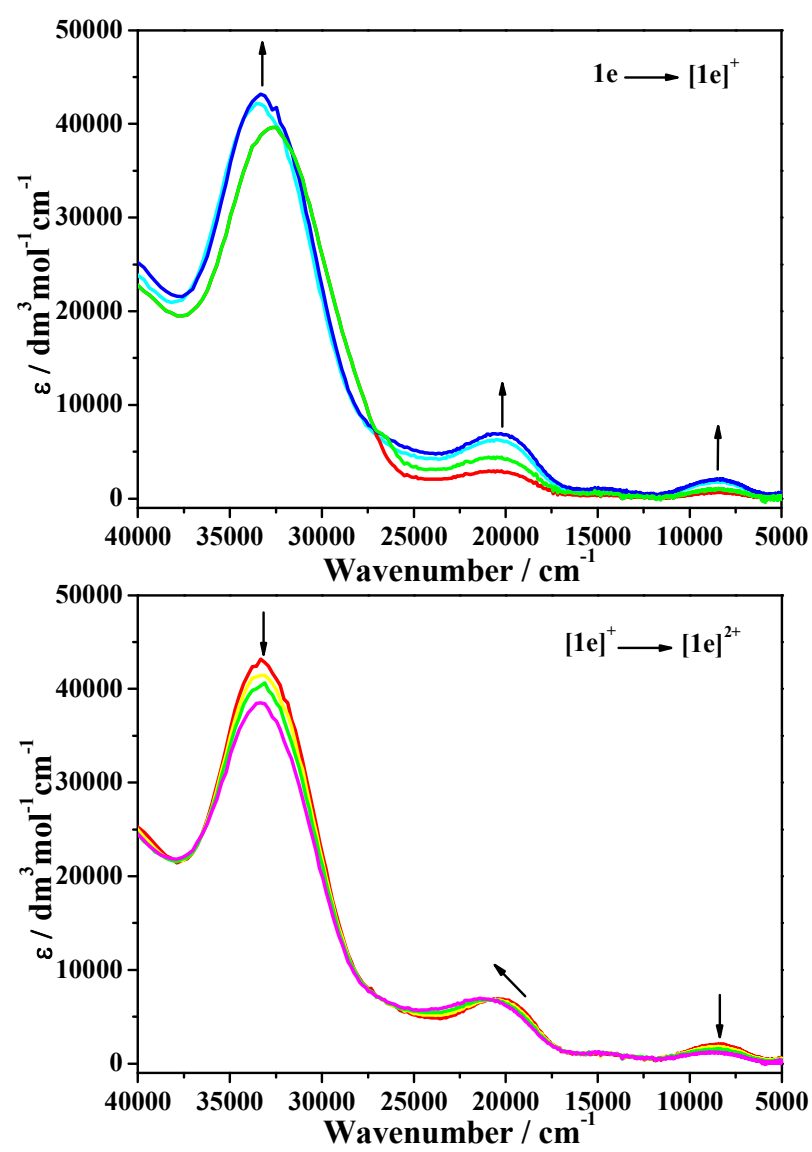

Figure 5. Changes in UV-vis-NIR absorption spectra recorded during the reversible oxidation of complex 1e to $[\mathbf{1 e}]^{+}$(top) and $[\mathbf{1 e}]^{2+}$ (bottom) in $\mathrm{CH}_{2} \mathrm{Cl}_{2} / 10^{-1} \mathrm{M} n-\mathrm{Bu}_{4} \mathrm{NPF}_{6}$ at $298 \mathrm{~K}$ within an OTTLE cell.

\section{Theoretical Calculations}

Density functional theory (DFT) calculations, using the B3LYP or CAM-B3LYP functionals, were performed to gain insight into the electronic structure of the one-electron-oxidized species $[\mathbf{1 a}]^{+}-[\mathbf{1 f}]^{+}$and selected mononuclear biradical dications $[\mathbf{1 a}]^{2+},[\mathbf{1 d}]^{2+}$ (unstable; Figure 2) and $[\mathbf{1 e}]^{2+}$. The basis set employed here is 6-31G* (Lanl2DZ for the Fe atom). To account for solvent effects, the conductor polarizable continuum model $(\mathrm{CPCM})$ in $\mathrm{CH}_{2} \mathrm{Cl}_{2}$ was employed for the ground-state structural optimization and analyses, as well as in the TD-DFT calculations of the electronic excitation energies. The pertinent data are presented in Figures 6-8 and Table 4, and in Supporting Information, Figures S7-S12.

The geometry-optimized DPAF derivatives, 1d-1f, (Figure S7) exhibit much 
shorter $\mathrm{N}-\mathrm{C}(\mathrm{Cp}$ ring) bonds (1.401-1.403 $\AA$ ) compared to the adjacent $\mathrm{N}-\mathrm{C}$ (phenyl) bonds $(1.424-1.429 \AA)$ and the normal N-C bonds $(1.421 \AA)$ in the TPA unit in 1e, in agreement with the crystal data for 1d (Table 1). These results indicate some conjugation between the redox-active ferrocenyl and DPA units, affecting the Fe(II) oxidation potential but not integrating them into one redox-active unit, in agreement with the preceding electrochemical section.

The spin density distribution in one-electron-oxidized $[\mathbf{1 a}]^{+}-[\mathbf{1 f}]^{+}$obtained with DFT is visualized in Figure 6. Importantly, in all these radical complexes, the spin density completely resides on (one of) the iron center(s), confirming the ferrocenyl-dominated initial oxidation steps, as indicated by the experimental voltammetric and spectroelectrochemical results. Regarding the dicationic dinuclear species, $\mathbf{1 b}]^{2+}$ and $[\mathbf{1 f}]^{2+}$, the symmetric bis(ferrocenium) biradical character is very clear from their electrochemical (Figure 2) and UV-vis-NIR absorption (Figure S3) characteristics.

The calculated distribution of the spin density in asymmetric mononuclear biradicals $[\mathbf{1 a}]^{2+},[\mathbf{1 d}]^{2+}$ and $[\mathbf{1 e}]^{2+}$ in their lowest-energy triplet ground states is shown in Figure 7. The data obtained for $[\mathbf{1} \mathbf{a}]^{2+}$ and $[\mathbf{1 e}]^{2+}$ prove the sequential ferrocenyl- and TAP-localized anodic steps deduced convincingly from the analysis of their voltammetric and spectroelectrochemical responses. The irreversible oxidation of $[\mathbf{1 d}]^{+}$to the reactive dication takes place, indeed, at the DPA site. Accordingly, the DPA site remains neutral in $[\mathbf{1 e}]^{2+}$, bridging between the energetically more accessible ferrocenium and $\mathrm{TAP}^{+}$sites. It becomes oxidized in the irreversible third anodic step, similar to the oxidation of $[\mathbf{1 d}]^{+}$(Figure 2 ). 


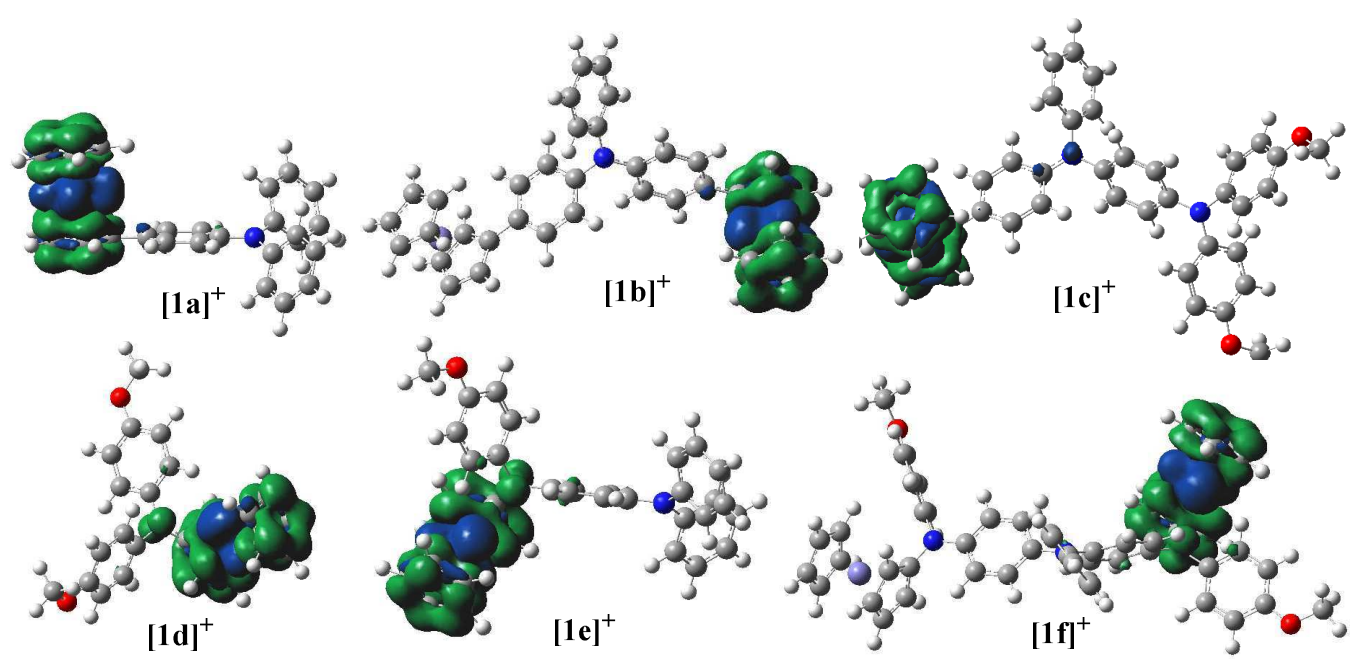

Figure 6. Calculated spin density distribution in $[\mathbf{1 a}]^{+}-[\mathbf{1 f}]^{+}$. Contour values: $\pm 0.02\left(\mathrm{e} / \mathrm{bohr}^{3}\right)^{1 / 2}$. B3LYP/6-31G*(Fe: Lanl2DZ)/CPCM / $\mathrm{CH}_{2} \mathrm{Cl}_{2}$. CAM-B3LYP was used for [1c $]^{+}$.

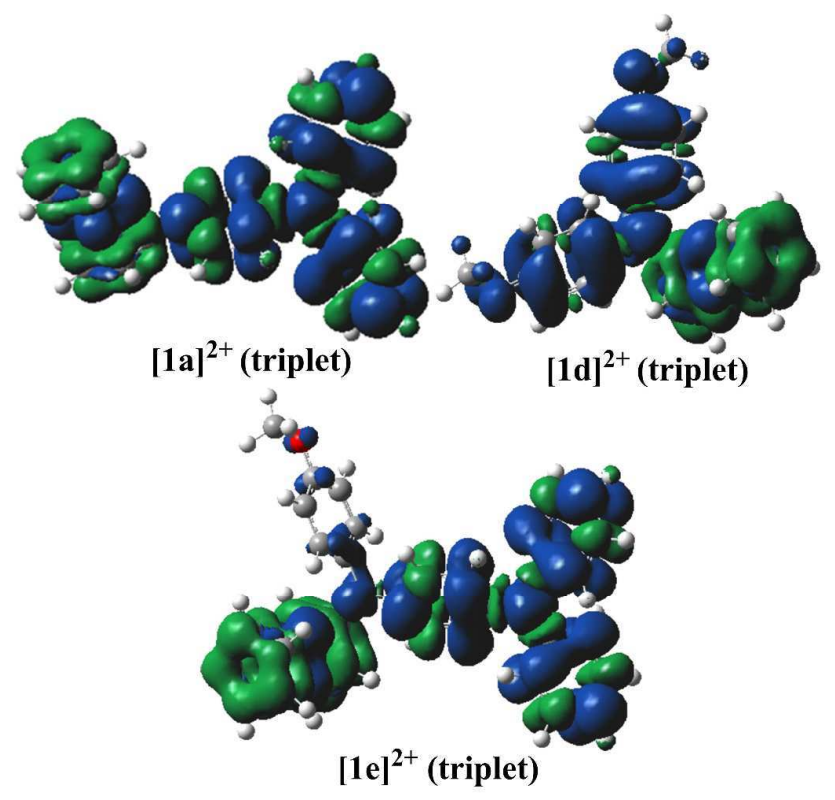

Figure 7. Calculated spin density distribution in biradicals $[\mathbf{1 a}]^{2+},[\mathbf{1 d}]^{2+}$ and $[\mathbf{1 e}]^{2+}$. Contour values: $\pm 0.02\left(\mathrm{e} / \mathrm{bohr}^{3}\right)^{1 / 2}$. B3LYP/6-31G*/CPCM $/ \mathrm{CH}_{2} \mathrm{Cl}_{2}$.

TD-DFT calculations were carried out to reproduce the low-energy absorption features in the experimental UV-vis-NIR spectra of the one- and two-electron-oxidized monoferrocenyl species, and to facilitate their assignment in 
support of the spin-localized bonding situation (Figures 6 and 7\}. The significant low-energy electronic transitions are presented in Table 4. According to the TD-DFT results, the characteristic absorption band of the monocationic species $[\mathbf{1 a}]^{+}-[\mathbf{1} \mathbf{f}]^{+}$ below $10000 \mathrm{~cm}^{-1}$ has been well reproduced, being consistently assigned to an electronic excitation within the amino-substituted ferrocenium site. ${ }^{15}$ This NIR band disappears upon further oxidation. The higher-energy visible absorptions of the monocations generally correspond to a charge transfer between the donor (di)amine (TPA, TPPD) and acceptor ferrocenium sites. The main B3LYP spin orbitals contributing to these electronic transitions in the stable mononuclear species are depicted in Figures S8 $\left([\mathbf{1 a}]^{+}\right)$and S9 $\left([\mathbf{1 d}]^{+}\right)$, and Figure 8 (right; $\left.[\mathbf{1 e}]^{+}\right)$. The $\beta$-HOSO is correctly localized on the TPA site in $[\mathbf{1} \mathbf{a}]^{+}$and $[\mathbf{1} \mathbf{e}]^{+}$, and the DPA site in $[\mathbf{1 d}]^{+}$. Notably, the B3LYP method indicated TPPD-dominated one-electron oxidation of 1c, which proved inconsistent with the spectro-electrochemical results. The alternative CAM-B3LYP method was applied successfully in this case. As a result, both the $\alpha$ - and $\beta$-LUSO of $[\mathbf{1 c}]^{+}$are ferrocenyl-localized whilst the $\beta$-HOSO resides on DTTP oxidizing in the following step to $[\mathbf{1 c}]^{2+}$. The spin orbitals participating in the low-energy optical excitation of $[\mathbf{1 c}]^{+}$are visualized in Figure 8 (left). The characteristic ferrocenium-based electronic transition around $7000 \mathrm{~cm}^{-1}$ (Table 4) can be spotted in the experimental spectra in Figure $4(a, b)$ due to its disappearance upon the oxidation of $[\mathbf{1 c}]^{+}$to the corresponding dication. The absorption band at $10220 \mathrm{~cm}^{-1}$, not reproduced by the TD DFT calculations of $[\mathbf{1 c}]^{+}$, may reflect an early-stage partial redox disproportionation of the monocation to $[\mathbf{1} \mathbf{c}]^{2+}$ absorbing in this region (Figure $4 \mathrm{~b}$ ). The anodic potential difference between the initial two oxidations of 1c is indeed small (Figure 2), becoming less resolved at the higher concentration used for the spectroelectrochemical experiment.

The visible electronic excitation of stable triplet biradical $[\mathbf{1 a}]^{2+}$ involves occupied and empty frontier spin orbitals of $\mathrm{TPA}^{+}$with a variable subordinate contribution from phenylferrocenium; the excitation at ca $500 \mathrm{~nm}$ is exceptional, featuring a strong TPA ${ }^{+}$-to-phenylferrocenium charge transfer character (Figure S10). In contrast, the electronic absorption of $[\mathbf{1 e}]^{2+}$ in the visible region is dominated by 
the charge transfer from the non-oxidized donor (Cp)DPA bridge to the $\mathrm{TPA}^{+}$moiety. Importantly, also the $\beta$-HOSO of $[\mathbf{1} \mathbf{e}]^{2+}$ is dominantly DPA-localized (Figure S12), in agreement with the irreversible oxidation to $[\mathbf{1 e}]^{3+}$. Finally, unstable $[\mathbf{1 d}]^{2+}$ was also calculated to confirm the DPA-based (irreversible) oxidation of the cationic precursor (Figure S11). Its electronic excitation has been predicted (a) in the NIR region (ca 950 $\mathrm{nm}$ ), having a strong $\mathrm{DPA}^{+}$intra-ligand character, with a subordinate contribution from a charge transfer to the $\mathrm{N}-\mathrm{CpFe}^{+}$part, and (b) in the visible region (ca $600 \mathrm{~nm}$ ) featuring a mixed $\mathrm{DPA}^{+}$-to-ferrocenium charge transfer and $\mathrm{DPA}^{+}$intraligand absorption.

Table 4. Major electronic excitations in complexes $[\mathbf{1 a}]^{+}-[\mathbf{1} \mathbf{f}]^{+}$and $[\mathbf{1} \mathbf{a}]^{2+},[\mathbf{1 d}]^{2+},[\mathbf{1 e}]^{2+}$ determined by the TD-DFT method. ${ }^{a}$

\begin{tabular}{|c|c|c|c|c|c|c|}
\hline Complex & $\begin{array}{l}\text { Excited } \\
\text { State }\end{array}$ & $\begin{array}{l}v\left(\mathrm{~cm}^{-1}\right) \\
{[\lambda(\mathrm{nm})]}\end{array}$ & $\begin{array}{c}\text { Osc. } \\
\text { Strength } \\
(f)\end{array}$ & Major Contributions & Assignment & $\begin{array}{c}v_{\exp } \\
\left(\mathrm{cm}^{-1}\right)^{b}\end{array}$ \\
\hline \multirow{3}{*}[\mathbf{1a}]{$^{+}$} & $D_{2}$ & $\begin{array}{c}8530 \\
{[1172]}\end{array}$ & 0.071 & $\begin{array}{c}\beta \text {-HOSO- } 6 \rightarrow \beta \text {-LUSO } \\
(84 \%)\end{array}$ & $\mathrm{Fe} \rightarrow \mathrm{Fc}^{+}-\mathrm{Ph}$ & 7740 \\
\hline & $D_{4}$ & $\begin{array}{l}14180 \\
{[705]}\end{array}$ & 0.2908 & $\begin{array}{c}\alpha-\mathrm{HOSO} \rightarrow \alpha \text {-LUSO } \\
(56 \%) \\
\beta-\mathrm{HOSO} \rightarrow \beta \text {-LUSO } \\
(26 \%)\end{array}$ & $\mathrm{TPA} \rightarrow \mathrm{Fc}^{+}-\mathrm{Ph}$ & 19250 \\
\hline & $D_{10}$ & $\begin{array}{l}21050 \\
{[475]} \\
\end{array}$ & 0.2707 & $\begin{array}{c}\beta \text {-HOSO } \rightarrow \beta \text {-LUSO }+1 \\
(70 \%)\end{array}$ & $\mathrm{TPA} \rightarrow \mathrm{Fc}^{+}-\mathrm{Ph}$ & 23970 \\
\hline \multirow{3}{*}{$\begin{array}{c}{[\mathbf{1} \mathbf{a}]^{2+}} \\
\text { (biradical) }\end{array}$} & $D_{3}$ & $\begin{array}{l}13990 \\
{[715]}\end{array}$ & 0.1024 & $\begin{array}{c}\beta \text {-HOSO } \rightarrow \beta \text {-LUSO } \\
(64 \%) \\
\beta \text {-HOSO- } 2 \rightarrow \beta \text {-LUSO } \\
(36 \%)\end{array}$ & $\begin{array}{c}\mathrm{Fc}^{+} / \mathrm{TPA}^{+} \rightarrow \mathrm{TPA}^{+} \\
\mathrm{TPA}^{+} \text {localized }\end{array}$ & 13680 \\
\hline & $D_{6}$ & $\begin{array}{l}17010 \\
{[588]}\end{array}$ & 0.1361 & $\begin{array}{c}\beta \text {-HOSO- } 3 \rightarrow \beta \text {-LUSO } \\
(67 \%)\end{array}$ & $\mathrm{TPA}^{+}$localized & $19540^{c}$ \\
\hline & $D_{12}$ & $\begin{array}{l}20160 \\
{[496]}\end{array}$ & 0.1375 & $\begin{array}{c}\alpha-\mathrm{HOSO} \rightarrow \alpha-\text {-LUSO } \\
(64 \%)\end{array}$ & $\mathrm{TPA}^{+} \rightarrow \mathrm{Fc}^{+}-\mathrm{Ph}$ & $19540^{c}$ \\
\hline \multirow[t]{2}{*}[\mathbf{1b}]{$^{+}$} & $D_{2}$ & $\begin{array}{c}8500 \\
{[1177]}\end{array}$ & 0.0108 & $\begin{array}{c}\beta \text {-HOSO- } 13 \rightarrow \beta \text {-LUSO } \\
(72 \%) \\
\beta \text {-HOSO- } 12 \rightarrow \beta \text {-LUSO } \\
(15 \%)\end{array}$ & $\begin{array}{c}\mathrm{Fe} \rightarrow \mathrm{Fc}^{+}-\mathrm{Ph} \\
\mathrm{Fc}-\mathrm{TPA} \rightarrow \mathrm{Fc}^{+}-\mathrm{Ph}\end{array}$ & $7450^{d}$ \\
\hline & $D_{8}$ & $\begin{array}{l}13530 \\
{[739]}\end{array}$ & 0.2971 & $\begin{array}{c}\alpha-\mathrm{HOSO} \rightarrow \alpha \text {-LUSO } \\
(48 \%)\end{array}$ & $\begin{array}{c}\mathrm{Fc}-\mathrm{TPA} \rightarrow \mathrm{Fc}^{+}-\mathrm{Ph} \\
\mathrm{LMCT} / \mathrm{ILCT}\end{array}$ & $18160^{d}$ \\
\hline
\end{tabular}


$\beta$-HOSO $\rightarrow \beta$-LUSO

$(29 \%)$

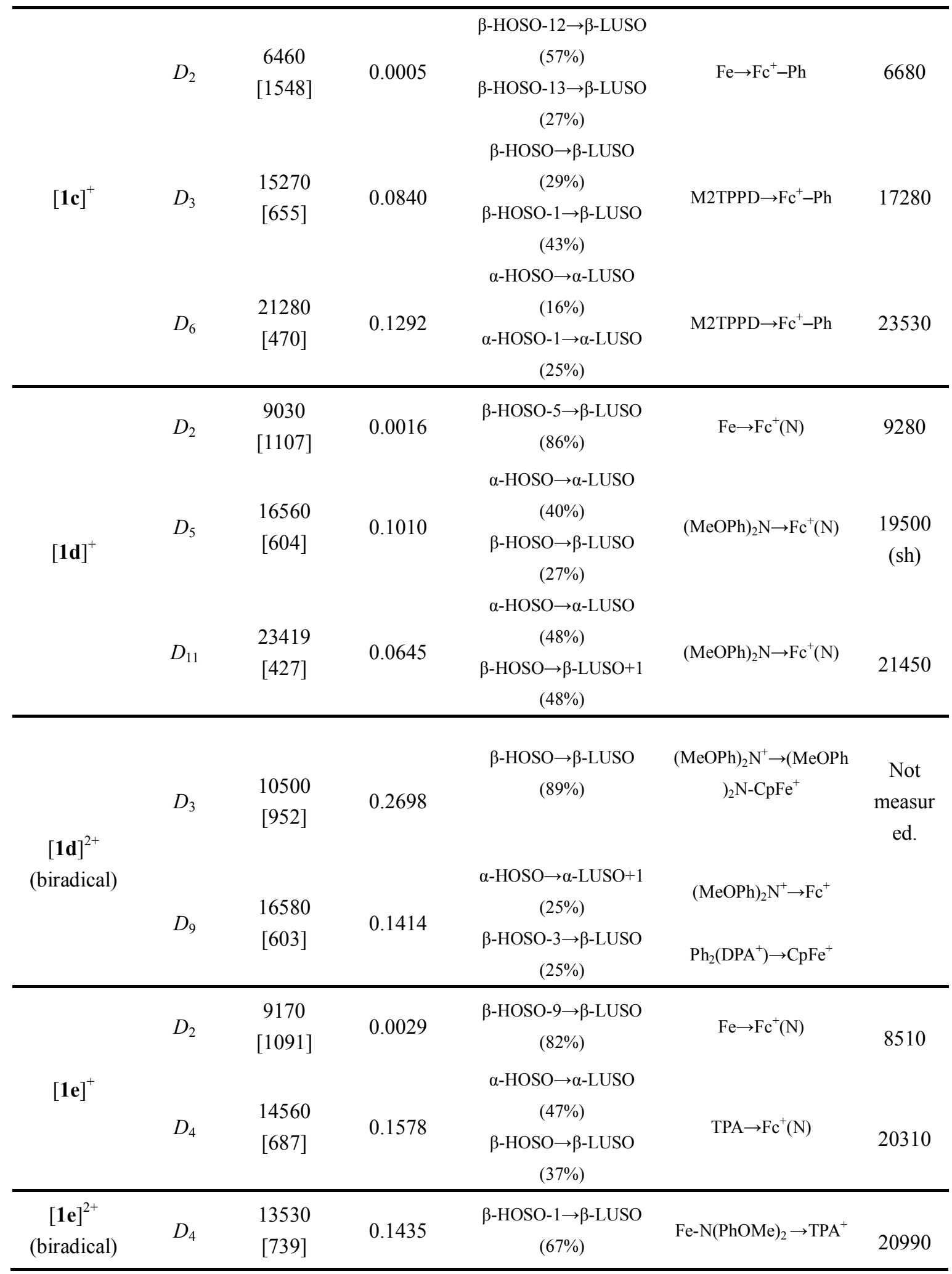

${ }^{a}$ B3LYP/6-31G*(Fe: Lanl2DZ) /CPCM / $\mathrm{CH}_{2} \mathrm{Cl}_{2}$. CAM-B3LYP was used for $[\mathbf{1 c}]^{+}{ }^{b}$ Taken from

Table 3. ${ }^{c}$ Asymmetric broad band encompassing the two calculated electronic transitions. ${ }^{d}[\mathbf{1 b}]^{+}$ 
undergoes redox disproportionation (Table 2) and the absorption maxima listed in Table 4 correspond to the initial phase of the anodic electrolysis.

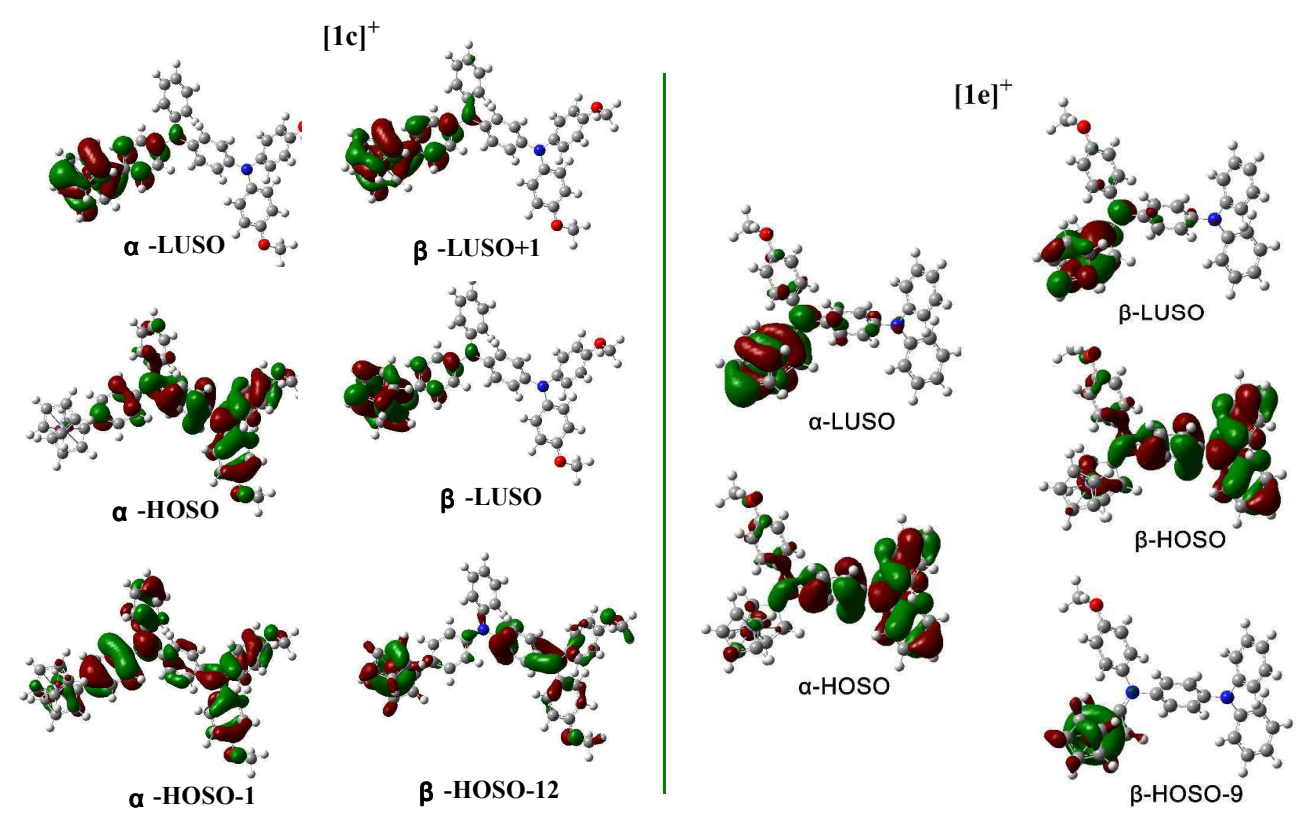

Figure 8. Spin orbitals involved in the major electronic excitations of $[\mathbf{1 c}]^{+}$(left) and $[\mathbf{1 e}]^{+}$(right) presented in Table 4. CAM-B3LYP $\quad\left([\mathbf{1 c}]^{+}\right)$or B3LYP $\left([\mathbf{1 e}]^{+}\right) / 6-31 \mathrm{G}^{*} \quad(\mathrm{Fe}$ : Lanl2DZ)/CPCM/ $/ \mathrm{CH}_{2} \mathrm{Cl}_{2}$.

\section{Conclusions}

This work presents a series of mono- and bis(ferrocenyl)-substituted TPA (1a, 1b), TPPD (1c), and Cp-DPA (1d-1f) derivatives depicted in Chart 1. The electrochemical and UV-vis-NIR spectroelectrochemical results have consistently revealed that the first anodic steps for $\mathbf{1 a}-\mathbf{1 f}$ is associated with one-electron oxidation of the ferrocenyl units, being followed by donor TPA substituents (absent in 1d) and, finally, Cp-bound DPA (or diphenylferrocenyl amine). The latter donor segments oxidize irreversibly and facilitate the preceding ferrocenyl oxidation. TD-DFT calculations at the B3LYP or CAM-B3LYP levels (successfully applied for reference phenylferrocenium) have disclosed that the characteristic absorption bands of the monocationic radical species $[\mathbf{1} \mathbf{a}]^{+}-[\mathbf{1 e}]^{+}$in the near-IR region involve excitation within the oxidized ferrocenium site; the anticipated amine-to-ferrocenium 
charge-transfer absorption has been encountered in the visible spectral region. Mononuclear biradicals $[\mathbf{1 a}]^{2+},[\mathbf{1 d}]^{2+}$ (unstable) and $[\mathbf{1 e}]^{2+}$ reside in a triplet ground state. The symmetric TPA-bridged diferrocenyl, $\mathbf{1 b}$, and bis(phenylaminoferrocenyl), 1f, complexes behave as localized redox systems with minimal interaction between the iron centres, undergoing facile redox disproportionation in the one-electron-oxidized state. We trust that new insights obtained from detailed studies of such systems containing multiple redox-responsive components will further advance rational design, understanding and exploration of new systems in materials chemistry based on electron-rich substituted ferrocenes.

\section{Experimental Section}

General Materials. All manipulations were carried out under a dry argon gas atmosphere by using standard Schlenk techniques, unless stated otherwise. Solvents were pre-dried and distilled under argon prior to use, except those used directly for spectroscopic measurements, which were of spectroscopic grade. The starting materials (4-bromophenyl)diphenylamine (2a) ${ }^{16}$, bis(4-bromophenyl)phenylamine (2b) ${ }^{16}, \quad$ bis(4-methoxyphenyl)amine ${ }^{17}, \quad N$-ferrocenyl-4-methoxyaniline $(\mathbf{2 d})^{18}$ and aminoferrocene (3d) ${ }^{19}$ were prepared by the procedures described in the literatures. Target complexes 1a-1f were prepared along the synthetic route presented in Scheme 1. Other reagents were purchased and used as received.

Syntheses. Intermediate 2c. Bis(4-methoxyphenyl)amine (200 mg, $0.87 \mathrm{mmol}$ ), bis(4-bromophenyl)phenylamine (1.06 g, $2.60 \mathrm{mmol}), t$-BuONa (126 mg, $1.30 \mathrm{mmol}$ ), $\mathrm{Pd}(\mathrm{OAc})_{2}$ (3.9 mg, $0.017 \mathrm{mmol}$ ), and 1,1'-bis(diphenylphosphino)ferrocene (dppf) (24 $\mathrm{mg}, 0.04 \mathrm{mmol}$ ) were suspended in $5 \mathrm{~mL}$ of toluene. The resulting reaction mixture was stirred at $100{ }^{\circ} \mathrm{C}$ under nitrogen atmosphere for $36 \mathrm{~h}$. After the reaction mixture was cooled to ambient temperature, the crude product was purified by column chromatography (eluent: petroleum ether/ethyl acetate, 20/1). After recrystallization from methanol, the product was obtained as light yellow solid. Yield: $336 \mathrm{mg}$ (70\%). ${ }^{1} \mathrm{H}$ NMR $\left(400 \mathrm{MHz}, \mathrm{CDCl}_{3}\right): \delta 3.75\left(\mathrm{~s}, 6 \mathrm{H}, \mathrm{OCH}_{3}-\mathrm{H}\right), 6.79-7.25(\mathrm{~m}, 21 \mathrm{H}, \mathrm{Ar}-\mathrm{H}) .{ }^{13} \mathrm{C}$ NMR $\left(100 \mathrm{MHz}, \mathrm{CDCl}_{3}\right): \delta 55.5\left(\mathrm{OCH}_{3}\right), 114.5,121.5-121.8,122.4,123.5-124.3$, 
126.2, 129.0, 131.7, 131.9, 139.7, 139.9, 147.0, 155.5 (Ar). Anal. Calcd for $\mathrm{C}_{32} \mathrm{H}_{27} \mathrm{BrN}_{2} \mathrm{O}_{2}: \mathrm{C}, 69.69 ; \mathrm{H}, 4.94 ; \mathrm{N}, 5.08$. Found: C, 69.85; H, 4.89; N, 5.13.

Intermediate $2 \boldsymbol{e}$. Aminoferrocene (173 $\mathrm{mg}, 0.90 \quad \mathrm{mmol})$, (4-bromophenyl)diphenylamine (279 mg, $0.90 \mathrm{mmol}), t$-BuONa (248 mg, $2.60 \mathrm{mmol}$ ), $\mathrm{Pd}_{2}(\mathrm{dba})_{3}(32 \mathrm{mg}, 0.030 \mathrm{mmol}$ ), and (+/-)-2,2'-bis(diphenylphosphino)-1,1'-binaphthyl (BINAP) (19 mg, $0.030 \mathrm{mmol}$ ) were suspended in $5 \mathrm{~mL}$ of toluene. The resulting reaction mixture was stirred at $100{ }^{\circ} \mathrm{C}$ under nitrogen atmosphere for $72 \mathrm{~h}$. After the reaction mixture was cooled to ambient temperature, the crude product was purified by column chromatography (eluent: petroleum ether/ethyl acetate, 60/1). The pure product was obtained as yellow solid. Yield: $172 \mathrm{mg}$ (45\%). ${ }^{1} \mathrm{H}$ NMR (400 MHz, $\left.\mathrm{CDCl}_{3}\right): \delta 4.13(\mathrm{~s}, 2 \mathrm{H}, \mathrm{Fc}-\mathrm{H}), 4.22(\mathrm{~s}, 5 \mathrm{H}, \mathrm{Fc}-\mathrm{H}), 4.31(\mathrm{~s}, 2 \mathrm{H}, \mathrm{Fc}-\mathrm{H}), 6.69(\mathrm{~s}, 1 \mathrm{H}$, $\mathrm{N}-\mathrm{H}), 6.87-6.90$ (t, $J=12 \mathrm{~Hz}, 2 \mathrm{H}, \operatorname{Ar}-\mathrm{H}), 7.00-7.02$ (d, $J=8 \mathrm{~Hz}, 6 \mathrm{H}, \operatorname{Ar}-\mathrm{H})$, 7.16-7.22 (m, 6H, Ar-H). ${ }^{13} \mathrm{C}$ NMR (100 MHz, $\left.\mathrm{CDCl}_{3}\right): \delta 61.7,64.5,68.8(\mathrm{Fc}), 100.6$, $115.6,121.4,122.5,127.0,128.8,138.8,142.2,147.9$ (Ar). Anal. Calcd for $\mathrm{C}_{28} \mathrm{H}_{24} \mathrm{FeN}_{2}$ : C, 75.68; H, 5.44; N, 6.30. Found: C, 75.43; H, 5.37; N, 6.22.

Intermediate $2 \boldsymbol{f}$. Aminoferrocene (201 $\mathrm{mg}, 1.00 \mathrm{mmol})$, bis(4-bromophenyl)phenylamine (202 mg, $0.50 \mathrm{mmol}), t$-BuONa (144 mg, 1.50 mmol), $\operatorname{Pd}_{2}(\mathrm{dba})_{3}(18 \mathrm{mg}, 0.02 \mathrm{mmol})$, and BINAP (13mg, $\left.0.02 \mathrm{mmol}\right)$ were suspended in $5 \mathrm{~mL}$ of toluene. The resulting reaction mixture was stirred at $100{ }^{\circ} \mathrm{C}$ under nitrogen atmosphere for $55 \mathrm{~h}$. After the reaction mixture was cooled to ambient temperature, the crude product was purified by column chromatography (eluent: petroleum ether/ethyl acetate, 10/1). After recrystallization from hexane, the product was obtained as yellow solid. Yield: $128 \mathrm{mg}(40 \%) .{ }^{1} \mathrm{H} \mathrm{NMR}\left(600 \mathrm{MHz}, \mathrm{CDCl}_{3}\right): \delta$ 4.07 (s, 4H, Fc-H), 4.20 (s, 10H, Fc-H), 4.26 (s, 4H, Fc-H), 4.45 (s, 2H, N-H), 6.97-7.16 (m, 13H, Ar-H). ${ }^{13} \mathrm{C}$ NMR (100 MHz, DMSO- $\left.d_{6}\right): \delta 59.3,63.4,68.3(\mathrm{Fc})$, 101.4, 115.1, 118.1, 126.3, 128.6, 137.2, 142.0, 148.7 (Ar). Anal. Calcd for $\mathrm{C}_{38} \mathrm{H}_{33} \mathrm{Fe}_{2} \mathrm{~N}_{3}$ : C, 70.94; H, 5.17; N, 6.53. Found: C, 70.65; H, 5.08; N, 6.58.

Target complexes 1a-1f were prepared along the synthetic route presented in Scheme 1.

Preparation of 4-(diphenylamino)phenylferrocene, $\mathbf{1 a}$. (4-Bromophenyl)diphenylamine (235 mg, $0.73 \mathrm{mmol})$, ferrocenylboronic acid (200 $\mathrm{mg}, 0.87 \mathrm{mmol}), \mathrm{K}_{3} \mathrm{PO}_{4}(462 \mathrm{mg}, 2.20 \mathrm{mmol}), \mathrm{Pd}(\mathrm{OAc})_{2}(1.6 \mathrm{mg}, 0.007 \mathrm{mmol})$, and 2-(dicyclohexylphosphino)biphenyl ( $5 \mathrm{mg}, 0.015 \mathrm{mmol})$ were suspended in $5 \mathrm{~mL}$ of 
toluene. The resulting reaction mixture was stirred at $110{ }^{\circ} \mathrm{C}$ under nitrogen atmosphere for $36 \mathrm{~h}$. After the reaction mixture was cooled to ambient temperature, the crude product was purified by column chromatography (eluent: dichloromethane/petroleum ether 3:10 (v/v)). After recrystallization from methanol, the product was obtained as yellow solid. Yield: $177 \mathrm{mg}(56 \%) .{ }^{1} \mathrm{H}$ NMR $(600 \mathrm{MHz}$, $\left.\mathrm{CDCl}_{3}\right): \delta 4.06(\mathrm{~s}, 5 \mathrm{H}, \mathrm{Fc}-\mathrm{H}), 4.28(\mathrm{~s}, 2 \mathrm{H}, \mathrm{Fc}-\mathrm{H}), 4.58(\mathrm{~s}, 2 \mathrm{H}, \mathrm{Fc}-\mathrm{H}), 7.01$ (t, $J=12$ Hz, 4H, Ar-H), 7.11 (d, $J=6$ Hz, 4H, Ar-H), 7.24-7.27 (m, 4H, Ar-H), 7.34-7.35 (d, $J$ $=6 \mathrm{~Hz}, 2 \mathrm{H}, \mathrm{Ar}-\mathrm{H}) .{ }^{13} \mathrm{C} \mathrm{NMR}\left(100 \mathrm{MHz}, \mathrm{CDCl}_{3}\right): \delta 66.2,68.6,69.5,85.5(\mathrm{Fc}), 122.4$, 123.9, 126.7, 127.0, 129.0, 133.2, 145.4, 147.5 (Ar). Anal. Calcd for $\mathrm{C}_{28} \mathrm{H}_{23} \mathrm{FeN}$ : C, 78.33; H, 5.40; N, 3.26. Found: C, 78.56; H, 5.29; N, 3.31.

Preparation of $\mathbf{1 b}$. 4,4'-(Dibromo)triphenylamine (353 $\mathrm{mg}, 0.88 \mathrm{mmol}$ ), ferrocenylboronic acid (483 mg, $2.00 \mathrm{mmol}$ ), $\mathrm{K}_{3} \mathrm{PO}_{4}$ (558 mg, $2.60 \mathrm{mmol}$ ), $\mathrm{Pd}(\mathrm{OAc})_{2}$ (4 mg, $0.018 \mathrm{mmol}$ ), and 2-(dicyclohexylphosphino)biphenyl (12 mg, $0.035 \mathrm{mmol})$ were suspended in $6 \mathrm{~mL}$ of toluene. The resulting reaction mixture was stirred at $110{ }^{\circ} \mathrm{C}$ under nitrogen atmosphere for $48 \mathrm{~h}$. After the reaction mixture was cooled to ambient temperature, the crude product was purified by column chromatography (eluent: dichloromethane/petroleum ether 1:4 (v/v)). After recrystallization from methanol, the product was obtained as yellow solid. Yield: $216 \mathrm{mg}(40 \%) .{ }^{1} \mathrm{H}$ NMR $\left(400 \mathrm{MHz}, \mathrm{CDCl}_{3}\right): \delta 4.05$ (s, 10H, Fc-H), 4.26 (s, 4H, Fc-H), 4.56 (s, 4H, Fc-H), 7.00 (d, $J=4 \mathrm{~Hz}, 4 \mathrm{H}, \operatorname{Ar}-\mathrm{H}), 7.10(\mathrm{~d}, J=4 \mathrm{~Hz}, 2 \mathrm{H}, \operatorname{Ar}-\mathrm{H}), 7.22(\mathrm{~d}, J=8 \mathrm{~Hz}, 2 \mathrm{H}$, Ar-H), 7.32 (d, $J=8 \mathrm{~Hz}, 4 \mathrm{H}, \mathrm{Ar}-\mathrm{H}), 7.42$ (d, $J=8 \mathrm{~Hz}, 1 \mathrm{H}, \mathrm{Ar}-\mathrm{H}) .{ }^{13} \mathrm{C}$ NMR $(100$ $\left.\mathrm{MHz}, \mathrm{CDCl}_{3}\right): \delta 66.1,68.6,69.4,85.4(\mathrm{Fc}), 122.3,123.7,126.6,127.0,128.9,133.1$, 145.3, 147.4 (Ar). Anal. Calcd for $\mathrm{C}_{38} \mathrm{H}_{31} \mathrm{Fe}_{2} \mathrm{~N}$ : C, 74.41; H, 5.09; N, 2.28. Found: C, 74.17; H, 4.98; N, 2.30 .

Preparation of 1c. 2c (108 mg, $0.20 \mathrm{mmol})$, ferrocenylboronic acid (54 mg, 0.24 $\mathrm{mmol}), \mathrm{K}_{2} \mathrm{CO}_{3}(82 \mathrm{mg}, 0.60 \mathrm{mmol}), \operatorname{Pd}(\mathrm{OAc})_{2}(0.9 \mathrm{mg}, 0.004 \mathrm{mmol})$, and 1,1'-bis(diphenylphosphino)ferrocene $(6 \mathrm{mg}, 0.01 \mathrm{mmol}$ ) were suspended in $5 \mathrm{~mL}$ of toluene. The resulting reaction mixture was stirred at $100{ }^{\circ} \mathrm{C}$ under nitrogen atmosphere for $48 \mathrm{~h}$. After the reaction mixture was cooled to ambient temperature, the crude product was purified by column chromatography (eluent: petroleum ether/ethyl acetate 32:3 (v/v)). After recrystallization from methanol, the product was obtained as yellow solid 78mg. Yield: $61 \%$. ${ }^{1} \mathrm{H}$ NMR (400 MHz, $\mathrm{CDCl}_{3}$ ): $\delta 3.78$ (s, 6H, OMe-H), 4.04 (s, 5H, Fc-H), 4.26 (s, 2H, Fc-H ), 4.55 (s, 2H, Fc-H ), 6.79-6.85 (m, 6H, Ar-H), 6.91-6.97 (m, 5H, Ar-H), 7.02-7.07 (m, 6H, Ar-H), 7.19-7.21 (d, $J=8$ 
$\mathrm{Hz}, 2 \mathrm{H}, \mathrm{Ar}-\mathrm{H}), 7.29-7.31(\mathrm{~d}, J=8 \mathrm{~Hz}, 2 \mathrm{H}, \mathrm{Ar}-\mathrm{H}) .{ }^{13} \mathrm{C} \mathrm{NMR}\left(100 \mathrm{MHz}, \mathrm{CDCl}_{3}\right): \delta$ 55.5 (OMe), 66.2, 68.6, $69.5(\mathrm{Fc}), 85.8,114.5,121.8,122.1,123.0,125.8,126.7$, $128.9,132.5,140.6,141.1,144.2,145.7,147.7,155.3$ (Ar). Anal. Calcd for $\mathrm{C}_{42} \mathrm{H}_{36} \mathrm{FeN}_{2} \mathrm{O}_{2}$ : C, 76.83; H, 5.53; N, 4.27;. Found: C, 76.97; H, 5.48; N, 4.18.

Preparation of bis(4-methoxylphenyl)aminoferrocene, $\mathbf{l d}$. $N$-Ferrocenyl-4-methoxyaniline $(87 \mathrm{mg}, 0.28 \mathrm{mmol})$, 4-bromoanisole $(0.07 \mathrm{ml}, 0.57$ mmol), $t$-BuONa (81 mg, $0.84 \mathrm{mmol}), \mathrm{Pd}_{2}(\mathrm{dba})_{3}(10 \mathrm{mg}, 0.01 \mathrm{mmol})$, and BINAP (7 $\mathrm{mg}, 0.01 \mathrm{mmol}$ ) were suspended in $4 \mathrm{~mL}$ of toluene. The resulting reaction mixture was stirred at $100{ }^{\circ} \mathrm{C}$ for under nitrogen atmosphere $60 \mathrm{~h}$. After the reaction mixture was cooled to ambient temperature, the crude product was purified by column chromatography (eluent: petroleum ether/ethyl acetate 300:1 (v/v)). The pure product was obtained as yellow solid. Yield: $60 \mathrm{mg}(52 \%) .{ }^{1} \mathrm{H}$ NMR (400 $\left.\mathrm{MHz}, \mathrm{CDCl}_{3}\right): \delta$ 3.79 (s, 5H, Fc-H), 3.88 (s, 2H, Fc-H), 3.94 (s, 2H, Fc-H), 4.17 (s, 6H, OMe-H), 6.83-6.85 (d, $J=8 \mathrm{~Hz}, 4 \mathrm{H}, \mathrm{Ar}-\mathrm{H}), 7.20-7.22(\mathrm{~d}, J=8 \mathrm{~Hz}, 4 \mathrm{H}, \mathrm{Ar}-\mathrm{H}) .{ }^{13} \mathrm{C}$ NMR $(100$ $\mathrm{MHz}, \mathrm{CDCl}_{3}$ ): $\delta 55.5$ (OMe), 58.1, 63.4, $68.63(\mathrm{Fc}), 109.0,114.2,125.9,140.7,155.3$ (Ar). Anal. Calcd for $\mathrm{C}_{24} \mathrm{H}_{23} \mathrm{FeNO}_{2}: \mathrm{C}, 69.75 ; \mathrm{H}, 5.61 ; \mathrm{N}, 3.39$. Found: C, 69.58; H, $5.43 ; \mathrm{N}, 3.43$.

Preparation of 1e. 2e (163 mg, $0.40 \mathrm{mmol})$, 4-bromoanisole $(0.09 \mathrm{ml}, 0.80$ mmol), $t$-BuONa (115 mg, $1.20 \mathrm{mmol}), \mathrm{Pd}_{2}(\mathrm{dba})_{3}(18 \mathrm{mg}, 0.02 \mathrm{mmol})$, and BINAP (12 $\mathrm{mg}, 0.02 \mathrm{mmol}$ ) were suspended in $5 \mathrm{~mL}$ of toluene. The resulting reaction mixture was stirred at $100{ }^{\circ} \mathrm{C}$ under nitrogen atmosphere for $50 \mathrm{~h}$. After the reaction mixture was cooled to ambient temperature, the crude product was purified by column chromatography (eluent: petroleum ether/ethyl acetate 100:1 (v/v)). After recrystallization from methanol, the product was obtained as yellow solid. Yield: 90 mg (45\%). ${ }^{1} \mathrm{H}$ NMR (400 MHz, $\mathrm{CDCl}_{3}$ ): $\delta 3.82$ (s, 3H, OMe-H), 3.96 (s, 4H, Fc-H), 4.14 (s, 5H, Fc-H), 6.89-6.97 (m, 6H, Ar-H), 7.04-7.11 (m, 6H, Ar-H), 7.18-7.23 (m, 6H, Ar-H). $\left.{ }^{13} \mathrm{C} \mathrm{NMR} \mathrm{(100} \mathrm{MHz,} \mathrm{CDCl}_{3}\right): \delta 55.5(\mathrm{OMe}), 59.4,63.7,68.7(\mathrm{Fc}), 107.9$, $114.4,121.9,122.4,123.2,125.3,127.9,128.9,140.2$, 141.0, 143.3, 147.7, 156.3 (Ar). Anal. Calcd for $\mathrm{C}_{35} \mathrm{H}_{30} \mathrm{FeN}_{2} \mathrm{O}$ : C, 76.37; H, 5.49; N, 5.09. Found: C, 76.11; H, 5.44; N, 5.07 .

Preparation of $\mathbf{1 f}$. Compound $\mathbf{2 f}$ (94 $\mathrm{mg}, 0.15 \mathrm{mmol})$, 4-bromoanisole $(0.08 \mathrm{ml}$, $0.60 \mathrm{mmol}), t$-BuONa (43 mg, $0.45 \mathrm{mmol}), \mathrm{Pd}_{2}(\mathrm{dba})_{3}(6 \mathrm{mg}, 0.006 \mathrm{mmol})$, and BINAP (4 mg, $0.006 \mathrm{mmol}$ ) were suspended in $5 \mathrm{~mL}$ of toluene. The resulting reaction mixture was stirred at $100{ }^{\circ} \mathrm{C}$ under nitrogen atmosphere for $72 \mathrm{~h}$. After the 
reaction mixture was cooled to ambient temperature, the crude product was purified by column chromatography (eluent: petroleum ether/ethyl acetate 40:1 (v/v)). The pure product was obtained as yellow solid. Yield: $58 \mathrm{mg}$ (45\%). ${ }^{1} \mathrm{H}$ NMR (400 MHz, $\mathrm{CDCl}_{3}$ ): $\delta 3.79$ (s, 6H, OMe-H), 3.95 (s, 8H, Fc-H), 4.13 (s, 10H, Fc-H), 6.87-6.89 (d, $J=8 \mathrm{~Hz}, 4 \mathrm{H}, \mathrm{Ar}-\mathrm{H}), 6.95-6.97$ (d, $J=8 \mathrm{~Hz}, 4 \mathrm{H}, \mathrm{Ar}-\mathrm{H}), 7.02-7.10$ (m, 8H, Ar-H), 7.15-7.22 (m, 5H, Ar-H). ${ }^{13} \mathrm{C}$ NMR (100 MHz, $\left.\mathrm{CDCl}_{3}\right): \delta 55.5(\mathrm{OMe}), 59.2,63.7$, 68.7 (Fc), 108.0, 114.4, 121.3, 122.3, 122.7, 124.0, 127.8, 128.8, 140.2, 141.3, 142.9, 148.0, 156.3 (Ar). Anal. Calcd for $\mathrm{C}_{52} \mathrm{H}_{45} \mathrm{Fe}_{2} \mathrm{~N}_{3} \mathrm{O}_{2}$ : C, 72.99; H, 5.30; N, 4.91. Found: C, 72.75; H, 5.41; N, 4.95 .

\section{X-ray Crystallography}

Single crystals of complex 1d suitable for X-ray analysis were grown from a solution in dichloromethane by slow solvent evaporation at room temperature. A selected crystal with approximate dimensions of $0.20 \times 0.10 \times 0.10 \mathrm{~mm}^{3}$ was mounted on a glass fiber for diffraction experiments. Intensity data were collected on a Nonius Kappa CCD diffractometer with Mo K $\alpha$ radiation (0.71073 $\AA$ ) at room temperature. The crystal structure was determined by a combination of direct methods $(\text { SHELXS-97) })^{20}$ and Fourier difference techniques and refined by full matrix least squares (SHELXL-97) ${ }^{21}$. All non-H atoms were refined anisotropically. The hydrogen atoms were placed in ideal positions and refined as riding atoms. The partial solvent molecules have been omitted. Selected bond distances and angles are given in Table 1. Further crystal data and details of the data collection are summarized in Table S1. Crystallographic data for the structure have been deposited with the Cambridge Crystallographic Data Centre as supplementary publication CCDC 1564068.

\section{Physical Measurements}

${ }^{1} \mathrm{H}$ and ${ }^{13} \mathrm{C}$ NMR spectra (Figures S13 - S30, Supporting Information) were collected on a Varian Mercury Plus 400 spectrometer $(400 \mathrm{MHz}) .{ }^{1} \mathrm{H}$ and ${ }^{13} \mathrm{C}$ NMR chemical shifts are given relative to $\mathrm{Si}\left(\mathrm{CH}_{3}\right)_{4}$. Elemental analyses $(\mathrm{C}, \mathrm{H}, \mathrm{N})$ were performed with a Vario ElIII Chnso instrument. The electrochemical measurements were performed on a $\mathrm{CHI} 660 \mathrm{C}$ potentiostat. A three-electrode single-compartment 
cell was used for the solution of complexes and supporting electrolyte in dry $\mathrm{CH}_{2} \mathrm{Cl}_{2}$. The solution was deaerated by bubbling with dry argon on a frit for about $10 \mathrm{~min}$ before the measurement. The analyte (complex, ligand) and electrolyte $\left(n-\mathrm{Bu}_{4} \mathrm{NPF}_{6}\right)$ concentrations were typically $10^{-3}$ and $10^{-1} \mathrm{~mol} \mathrm{dm}^{-3}$, respectively. A pre-polished $500-\mu \mathrm{m}$ diameter platinum disk working electrode, a platinum wire counter electrode, and an Ag wire pseudoreference electrode were used. Ferrocene was used as the internal potential reference. Spectroelectrochemical experiments at room temperature were performed with an airtight optically transparent thin-layer electrochemical (OTTLE) cell (optical path length of ca. $200 \mu \mathrm{m}$ ) equipped with a Pt minigrid working electrode and $\mathrm{CaF}_{2}$ windows. ${ }^{22}$ The cell was positioned in the sample compartment of a Shimadzu UV-3600 UV-vis-NIR spectrophotometer. The controlled-potential electrolyses were carried out with a $\mathrm{CHI} 660 \mathrm{C}$ potentiostat. The concentration of analyte samples was ca $2 \times 10^{-3} \mathrm{~mol} \mathrm{dm}^{-3}$. Dry $3 \times 10^{-1} \mathrm{M} n-\mathrm{Bu}_{4} \mathrm{NPF}_{6}$ was used as the supporting electrolyte.

\section{Computational Details}

DFT calculations were performed with the Gaussian $09 \operatorname{program}^{23}$, at the ${\mathrm{B} 3 L Y \mathrm{LP}^{24} \text { or CAM-B3LYP }}^{25} / 6-31 \mathrm{G}^{* 26}$ level of theory. The basis set employed was 6-31G* (Lanl2DZ for Fe atom). Geometry optimization was performed without any symmetry constraints. Electronic transitions were calculated by the time-dependent DFT (TD-DFT) method. The MO contributions were generated using the Multiwfn package and plotted using GaussView 5.0. The solvation effects in dichloromethane are included for a part of the calculations with the conductor-like polarizable continuum model (CPCM). ${ }^{27}$

\section{Acknowledgements}

The authors gratefully acknowledge financial support from the National Natural Science Foundation of China (21472059), the Overseas Talent Plan 111 Project 
B17019, the self-determined research funds of CCNU from the colleges' basic research and the operation of MOE (CCNU14A05009, CCNU14F01003).

\section{Author Information}

${ }^{a}$ Key Laboratory of Pesticide \& Chemical Biology, Ministry of Education, College of Chemistry, Central China Normal University, 152 Luoyu Road, Wuhan, Hubei 430079 (China)

E-mail: chshliu@mail.ccnu.edu.cn (S.H.Liu); f.hartl@reading.ac.uk (F.Hartl)

\section{Notes}

The authors declare no competing financial interest.

$\dagger$ Electronic supplementary information (ESI) available: Crystallographic information, Electrochemistry, UV-vis-NIR spectroelectrochemistry, DFT/TD-DFT, and NMR data.

\section{References and Notes}

1 (a) A. Hildebrandt and H. Lang, Organometallics, 2013, 32, 5640; (b) M. Lohan, F. Justaud, T. Roisnel, P. Ecorchard, H. Lang, and C. Lapinte, Organometallics, 2010, 29, 4804; (c) U. Pfaff, A. Hildebrandt, M. Korb, D. Schaarschmidt, M. Rosenkranz, A. Popov and H. Lang, Organometallics, 2015, 34, 2826; (d) D. Miesel, A. Hildebrandt, M. Korb, D. A. Wild, P. J. Low and H. Lang, Chem.- Eur. J., 2015, 21, 11545; (e) A. Hildebrandt and H. Lang, Dalton Trans., 2011, 40, 11831; (f) S. Chandra, C. Gäbler, C. Schliebe, H. Lang and D. Bahadur, New J. Chem., 2016, 40, 9046; (g) M. S. Inkpen, S. Scheerer, M. Linseis, A. J. P. White, R. F. Winter, T. Albrecht and N. J. Long, Nat. Chem., 2016, 8, 825.

2 (a) J. P. Lewtak, M. Landman, I. Fernández and J. C. Swarts, Inorg. Chem., 2016, 55, 2584; (b) F. Barrière, N. Camire, W. E. Geiger, U. T. Mueller-Westerhoff and R. Sanders, J. Am. Chem. Soc., 2002, 124, 7262; (c) J. Casado, S. R. González, M. C. R. Delgado, M. M. Oliva, J. T. L. Navarrete, R. Caballero, P. Cruz and F. Langa, Chem. 
Eur. J., 2009, 15, 2548; (d) A. K. Diallo, J.-C. Daran, F. Varret, J. Ruiz and D. Astruc, Angew. Chem. Int. Ed., 2009, 48, 3141; (e) S. J. Dammer, P. V. Solntsev, J. R. Sabin and V. N. Nemykin, Inorg. Chem., 2013, 52, 9496; (f) R. Breuer and M. Schmittel, Organometallics, 2012, 31, 1870; (g) W. R. Goetsch, P. V. Solntsev, C. V. Stappen, A. A. Purchel, S. V. Dudkin and V. N. Nemykin, Organometallics, 2014, 33, 145; (h) A. Hildebrandt, K. A. Khalyfeh, J. F. Nawroth and R. Jordan, Organometallics, 2016, 35, 3713 ; (i) K. Ventura, M. B. Smith, J. R. Prat, L. E. Echegoyen and D. Villagrán, J. Chem. Educ., 2017, 94, 526.

3 (a) G. Zhou, M. Baumgarten and K. Müllen, J. Am. Chem. Soc., 2007, 129, 12211; (b) C. Lambert, C. Risko, V. Coropceanu, J. Schelter, S. Amthor, N. E. Gruhn, J. C. Durivage and J.-L. Brédas, J. Am. Chem. Soc., 2005, 127, 8508; (c) K. Lancaster, S. A. Odom, S. C. Jones, S. Thayumanavan, S. R. Marder, J.-L. Brédas, V. Coropceanu and S. Barlow, J. Am. Chem. Soc., 2009, 131, 1717; (d) E. T. Seo, R. F. Nelson, J. M. Fritsch, L. S. Marcoux, D. W. Leedy and R. N. Adams, J. Am. Chem. Soc., 1966, 88, 3498; (e) H.-C. Cheng, K. Y. Chiu, S. H. Lu, C.-C. Chen, Y. W. Lee, T.-F. Yang, M. Y. Kuo, P. P.-Y. Chen and Y. O. Su, J. Phys. Chem. A., 2015, 119, 1933; (f) J. Hankache and O. S. Wenger, Chem Rev., 2011, 111, 5138.

4 (a) J. Zhang, S.-Z. Guo, Y.-B. Dong, L. Rao, J. Yin, G.-A. Yu, F. Hartl and S.-H. Liu, Inorg. Chem., 2017, 56, 1001; (b) M. Parthey, K. B. Vincent, M. Renz, P. A. Schauer, D. S. Yufit, J. A. K. Howard, M. Kaupp and P. J. Low, Inorg. Chem., 2014, 53, 1544; (c) A. Heckmann and C. Lambert, Angew. Chem. Int. Ed., 2012, 51, 326; (d) C. Lambert, G. Nöll and J. Schelter, Nat Mater., 2002, 1, 69; (e) C.-J. Yao, Y.-W. Zhong and J.-N. Yao, Inorg. Chem., 2013, 52, 10000; (f) S. Barlow, C. Risko, S. A. Odom, S. Zheng, V. Coropceanu, L. Beverina, J.-L. Brédas and S. R. Marder, J. Am. Chem. Soc., 2012, 134, 10146; (g) J. Zhang, G.-T. Liu, X.-Y. Wang, G.-A. Yu, J. Yin and S.-H. Liu, Dyes Pigments, 2017, 143, 416.

5 (a) M. A. Fox , R. L. Roberts, T. E. Baines, B. Le Guennic, J.-F. Halet, F. Hartl, D. S. Yufit, D. Albesa-Jové, J. A. K. Howard and P. J. Low, J. Am. Chem. Soc., 2008, 130, 3566; (b) J. Zhang, Z. Chen, L. Yang, F.-F. Pan, G.-A. Yu, J. Yin and S.-H. Liu, Sci. Rep., 2016, 6, 36310; (c) P. J. Low, Coord. Chem. Rev., 2013, 257, 1507; (d) L.-B. 
Gao, J. Kan, Y. Fan, L.-Y. Zhang, S.-H. Liu and Z.-N. Chen, Inorg. Chem., 2007, 46, 5651; (e) P. J. Low, Dalton Trans., 2005, 2821; (f) M. Akita and T. Koike, Dalton Trans., 2008, 3523; (g) J. Zhang, M.-X. Zhang, C.-F. Sun, M. Xu, F. Hartl, J. Yin, G.-A. Yu, L. Rao and S.-H. Liu, Organometallics, 2015, 34, 3967; (h) J.-W. Ying, I. P.-C. Liu, B. Xi, Y. Song, C. Campana, J.-L. Zuo and T. Ren, Angew. Chem. Int. Ed., $2010,49,954$.

6 (a) S. Roué, H. Sahnoune, L. Toupet, J.-F. Halet and C. Lapinte, Organometallics, 2016, 35, 2057; (b) Y. Li, O. Blacque, T. Fox, S. Luber, W. Polit, R. F. Winter, K. Venkatesana and H. Berke, Dalton Trans., 2016, 45, 5783; (c) Y.-W. Zhong, Z.-L. Gong, J.-Y. Shao and J.-N. Yao, Coord. Chem. Rev., 2016, 312, 22; (d) L.-B. Gao, L.-Y. Zhang, L.-X. Shi and Z.-N. Chen, Organometallics, 2005, 24, 1678; (e) H. Lei, X. Xiao, M. Meng, T. Cheng, Y. Shu, Y. N. Tan and C. Y. Liu, Inorg. Chimi. Acta., 2015, 424, 63; (f) Z. Cao, B. Xi, D. S. Jodoin, L. Zhang, S. P. Cummings, Y. Gao, S. F. Tyler, P. E. Fanwick, R. J. Crutchley and T. Ren, J. Am. Chem. Soc., 2014, 136, 12174.

7 (a) G. Grelaud, O. Cador, T. Roisnel, G. Argouarch, M. P. Cifuentes, M. G. Humphrey and F. Paul, Organometallics, 2012, 31, 1635; (b) B.-B. Cui, J.-H. Tang, J.-N. Yao and Y.-W. Zhong, Angew. Chem. Int. Ed., 2015, 54, 9192; (c) D. Fink, B. Weibert and R. F. Winter, Chem. Commun., 2016, 52, 6103; (d) W. Polit, T. Exner, E. Wuttke and R. F. Winter, BioInorg. React. Mech., 2012, 8, 85; (e) J.-H. Tang, J.-Y. Shao,Y.-Q. He, S.-H. Wu, J.-N. Yao and Y.-W. Zhong, Chem. -Eur. J., 2016, 22, 10341; (f) H.-C. Cheng, K. Y..Chiu, S. H. Lu, C.-C. Chen, Y. W. Lee, T.-F. Yang, M.Y. Kuo, P. P.-Y.Chen and Y. O. Su, J. Phys. Chem. A., 2015, 119, 1933; (g) K. Onitsuka, N. Ohara, F. Takei and S. Takahashi, Dalton Trans., 2006, 3693; (h) G. Grelaud, M. P. Cifuentes, T. Schwich, G. Argouarch, S. Petrie, R. Stranger, F. Paul and M. G. Humphrey, Eur. J. Inorg. Chem., 2012, 65; (i) K. Onitsuka, N. Ohara, F. Takei and S. Takahashi, Organometallics, 2008, 27, 25.

8 (a) J. A. Lee, B. N. Williams, K. R. Ogilby, K. L. Miller and P. L. Diaconescu, J. Organomet. Chem., 2011, 696, 4090; (b) Y.-W. Chang, M.-J. Huang, C.-C. Lai, C.-C. Chang, M.-P. Huang, C.-Y. Liao and C.-H. Cheng, Chem. Commun., 2016, 52, 14294; 
(c) A. Mendiratta, S. Barlow, M. W. Day and S. R. Marder, Organometallics, 1999, 18, 454. (d) S. Sethi, P. K. Das and N. Behera. J. Organomet. Chem., 2016, 824, 140. (e) C. C. Chiang, H. C. Chen, C. S. Lee, M. K. Leung, K. R. Lin and K. H. Hsieh. Chem. Mat., 2007, 20, 540. (f) Y. Shirota. J. Mater. Chem., 2000, $10,1$.

9 (a) Ö. Salih, S. Ellen, L. Annika and B. Carsten, Synthesis, 2007, 3, 389; (b) A. Houlton, P. T. Bishop, R. M. G. Roberts and J. S. M. Herberhold, J. Organomet. Chem., 1989, 364, 381; (c) W. E. Britton, R. Kashyap, M. El-Hashash, M. El-Kady and M. Herberhold, Organometallics, 1986, 5, 1029; (d) S.-X. Lu, V. V. Strelets, M. F. Ryan, W. J. Pietro and A. B. P. Lever, Inorg. Chem., 1996, 35, 1013.

10 W. Polit, P. Mücke, E. Wuttke, T. Exner and R. F. Winter, Organometallics, 2013, 32, 5461 .

11 D. Lionetti, A. J. Medvecz, V. Ugrinova, M. Quiroz-Guzman, B. C. Noll and S. N. Brown, Inorg. Chem., 2010, 49, 4687.

12 H. Murata and P. M. Lahti, J. Org. Chem., 2007, 72, 4974.

13 M. Parthey, K. B. Vincent, M. Renz, P. A. Schauer, D. S. Yufit, J. A. K. Howard, M. Kaupp and P. J. Low, Inorg. Chem., 2014, 53, 1544.

14 D. E. Richardson and H. Taube, Inorg. Chem., 1981, 20, 1278.

15 The reliability of the B3LYP and CAM-B3LYP methods employed for the TD DFT calculations of the low-lying electronic transitions exhibited by the studied singly oxidized TAP-ferrocenium and DPA-ferrocenium complexes, $[\mathbf{1 a}]^{+}-[\mathbf{1 e}]^{+}$(Table 4), was tested for phenylferrocenium, $[\mathrm{Ph}-\mathrm{Fc}]^{+}$, as the suited reference complex lacking the NIR absorption band. The results are presented in the Supporting Information, in a dedicated section preceding the depicted set of experimental NMR spectra (see Figures S13-S17 and the corresponding explanatory Figure captions).

16 L.-Q. Shi, C. He, D.-F. Zhu, Q.-G He, Y. Li, Y. Chen, Y.-X. Sun, Y.-Y. Fu, D. Wen, H.-M. Cao and J.-G. Cheng, J. Mater. Chem., 2012, 22, 11629.

17 K. Zhang, L. Wang, Y.-L. Liang, S.-Q. Yang, J. Liang, F.-Y. Cheng and J. Chen, Synth. Met., 2012, 162, 490.

18 C. A. Fleckenstein and H. Plenio, Organometallics, 2007, 26, 2758.

19 D. C. D. Butler and C. J. Richards, Organometallics, 2002, 21, 5433. 
20 G. M. Sheldrick, SHELXS-97, a Program for Crystal Structure Solution; University of Göttingen: Göttingen, Germany, 1997.

21 G. M. Sheldrick, SHELXL-97, a Program for Crystal Structure Refinement; University of Göttingen, Göttingen, Germany, 1997.

22 M. Krejčík, M. Daněk and F. Hart1, J. Electroanal. Chem. Interfacial Electrochem., 1991, 317, 179.

23 Gaussian 09, Revision D.01, M. J. Frisch, G. W. Trucks, H. B. Schlegel, G. E. Scuseria, M. A. Robb, J. R. Cheeseman, G. Scalmani, V. Barone, B. Mennucci, G. A. Petersson, H. Nakatsuji, M. Caricato, X. Li, H. P. Hratchian, A. F. Izmaylov, J. Bloino, G. Zheng, J. L. Sonnenberg, M. Hada, M. Ehara, K. Toyota, R. Fukuda, J. Hasegawa, M. Ishida, T. Nakajima, Y. Honda, O. Kitao, H. Nakai, T. Vreven, J. A. Montgomery, Jr., J. E. Peralta, F. Ogliaro, M. Bearpark, J. J. Heyd, E. Brothers, K. N. Kudin, V. N. Staroverov, R. Kobayashi, J. Normand, K. Raghavachari, A. Rendell, J. C. Burant, S. S. Iyengar, J. Tomasi, M. Cossi, N. Rega, J. M. Millam, M. Klene, J. E. Knox, J. B. Cross, V. Bakken, C. Adamo, J. Jaramillo, R. Gomperts, R. E. Stratmann, O. Yazyev, A. J. Austin, R. Cammi, C. Pomelli, J. W. Ochterski, R. L. Martin, K. Morokuma, V. G. Zakrzewski, G. A. Voth, P. Salvador, J. J. Dannenberg, S. Dapprich, A. D. Daniels, Ö. Farkas, J. B. Foresman, J. V. Ortiz, J. Cioslowski, and D. J. Fox, Gaussian, Inc., Wallingford CT, 2009.

24 (a) A. D. Becke, J. Chem. Phys., 1993, 98, 5648; (b) C. Lee, W. Yang and R. G. Parr, Phys. Rev. B., 1988, 37, 785.

25. T. Yanai, D. P.Tew and N. C. Handy, Chem. Phys. Lett., 2004, 393, 51-57.

26 T. H. Dunning, P. J. Hay in Modern Theoretical Chemistry, Vol. 3 (Ed.: H. F. Schaefer), Plenum, New York, 1976, p.1.

27 (a) V. Barone and M. Cossi, J. Phys. Chem. A., 1998, 102, 1995; (b) M. Cossi, N. Rega, G. Scalmani and V. Barone, J. Comput. Chem., 2003, 24, 669. 


\section{TOC and Graphical Abstract}

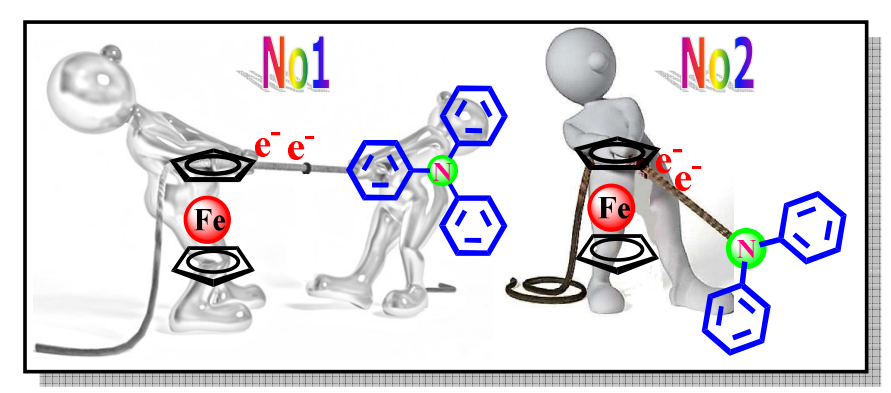

The multistep anodic behavior of two series of nonlinear (di)aminophenylferrocene, and diphenylaminoferrocene complexes is reported. The influence of the integration of diverse redox-active components on the sequential oxidation of these complexes has been explored. The first anodic steps all take place uniformly on the ferrocenyl units, followed by oxidation of the triphenylamine and $\mathrm{Cp}$-diphenylamine moieties. The assignment of the anodic steps has been supported by DFT calculations.
Ming-Xing Zhang, Jing Zhang, Jun Yin, František Hartl, * Sheng Hua Liu*

Page No. - Page No.

Title: Anodic Electrochemistry of Mono- and Dinuclear Aminophenylferrocene and Diphenylaminoferrocene Complexes 


\title{
Anodic Electrochemistry of Mono- and Dinuclear Aminophenylferrocene and Diphenylaminoferrocene Complexes
}

\author{
Ming-Xing Zhang, ${ }^{\dagger, \S}$ Jing Zhang, ${ }^{\dagger}, \pi, \S$ Jun Yin, ${ }^{\dagger}$ František Hartl, ${ }^{*}{ }^{\star}$ Sheng-Hua Liu* ${ }^{*}$ \\ ${ }^{\dagger}$ Key Laboratory of Pesticide and Chemical Biology, Ministry of Education, College \\ of Chemistry, Central China Normal University, Wuhan 430079, P.R. China \\ " College of Chemistry, The Hong Kong University of Science and Technology, Clear \\ Water Bay, Kowloon, Hong Kong \\ ${ }^{\ddagger}$ Department of Chemistry, University of Reading, Whiteknights, Reading RG6 6AD, \\ $U K$ \\ ${ }^{\S}$ These authors contributed equally to this work.
}


Table S1. Crystal data and parameters of data collection and refinement for complex 1d.

\begin{tabular}{|c|c|}
\hline Complex & 1d \\
\hline Formula & $\mathrm{C}_{24} \mathrm{H}_{23} \mathrm{FeNO}_{2}$ \\
\hline Formula weight & 413.28 \\
\hline Temperature (K) & $296(2)$ \\
\hline Crystal system & Monoclinic \\
\hline Space group & $P 2(1) / c$ \\
\hline$a(\AA)$ & $17.7696(18)$ \\
\hline$b(\AA)$ & $9.6825(10)$ \\
\hline$c(\AA)$ & $22.947(2)$ \\
\hline$\alpha\left(^{\circ}\right)$ & 90 \\
\hline$\beta\left(^{\circ}\right)$ & $92.595(2)$ \\
\hline$\gamma\left({ }^{\circ}\right)$ & 90 \\
\hline$V\left(\AA^{3}\right)$ & $3944.1(7)$ \\
\hline$Z$ & 8 \\
\hline Density (calculated) $\left(\mathrm{Mg} / \mathrm{m}^{3}\right)$ & 1.392 \\
\hline Absorption coefficient $\left(\mathrm{mm}^{-1}\right)$ & 0.784 \\
\hline$F(000)$ & 1728 \\
\hline Crystal size $\left(\mathrm{mm}^{3}\right)$ & $0.20 \times 0.10 \times 0.10$ \\
\hline Theta range for data collection $\left(^{\circ}\right)$ & 1.78 to 27.45 \\
\hline Index ranges & $-23 \leq h \leq 23,-12 \leq k \leq 12,-29 \leq l \leq 29$ \\
\hline Reflections collected & 32836 \\
\hline Independent reflections & $8967[R($ int $)=0.0562]$ \\
\hline Max. and min. transmission & 0.9257 and 0.9118 \\
\hline Data / restraints / parameters & $8967 / 0$ / 510 \\
\hline Goodness-of-fit on $F^{2}$ & 0.997 \\
\hline Final $R$ indices $[I>2 \sigma(I)]$ & $R 1=0.0443, w R 2=0.1093$ \\
\hline$R$ indices (all data) & $R 1=0.0826, w R 2=0.1266$ \\
\hline Largest diff. peak and hole $\left(\mathrm{e}^{-3}\right)$ & 0.279 and -0.336 \\
\hline
\end{tabular}


Table S2. Bond lengths $[\AA]$ and angles [deg] for complex 1d.

\begin{tabular}{|c|c|c|c|}
\hline \multicolumn{4}{|c|}{ Bond lengths $[\AA]]$} \\
\hline $\mathrm{Fe} 1-\mathrm{C} 3$ & $2.028(3)$ & $\mathrm{C} 7-\mathrm{C} 8$ & $1.410(4)$ \\
\hline $\mathrm{Fe} 1-\mathrm{C} 2$ & $2.034(2)$ & $\mathrm{C} 11-\mathrm{C} 16$ & $1.369(4)$ \\
\hline $\mathrm{Fe} 1-\mathrm{C} 10$ & $2.036(3)$ & $\mathrm{C} 11-\mathrm{C} 12$ & $1.383(3)$ \\
\hline $\mathrm{Fe} 1-\mathrm{C} 4$ & $2.038(3)$ & $\mathrm{O} 1-\mathrm{C} 14$ & $1.372(3)$ \\
\hline $\mathrm{Fe} 1-\mathrm{C} 9$ & $2.038(3)$ & $\mathrm{O} 1-\mathrm{C} 17$ & $1.408(4)$ \\
\hline $\mathrm{Fe} 1-\mathrm{C} 7$ & $2.040(3)$ & $\mathrm{C} 19-\mathrm{C} 20$ & $1.369(4)$ \\
\hline $\mathrm{Fe} 1-\mathrm{C} 6$ & $2.040(3)$ & $\mathrm{C} 2-\mathrm{C} 3$ & $1.416(4)$ \\
\hline $\mathrm{Fe} 1-\mathrm{C} 8$ & $2.044(3)$ & $\mathrm{C} 21-\mathrm{C} 22$ & $1.382(4)$ \\
\hline $\mathrm{Fe} 1-\mathrm{C} 5$ & $2.061(3)$ & $\mathrm{C} 21-\mathrm{C} 20$ & $1.386(4)$ \\
\hline $\mathrm{Fe} 1-\mathrm{C} 1$ & $2.072(2)$ & $\mathrm{C} 9-\mathrm{C} 8$ & $1.403(4)$ \\
\hline $\mathrm{N} 1-\mathrm{C} 1$ & $1.411(3)$ & $\mathrm{C} 9-\mathrm{C} 10$ & $1.408(4)$ \\
\hline $\mathrm{N} 1-\mathrm{C} 18$ & $1.425(3)$ & $\mathrm{C} 10-\mathrm{C} 6$ & $1.415(4)$ \\
\hline $\mathrm{N} 1-\mathrm{C} 11$ & $1.439(3)$ & $\mathrm{C} 13-\mathrm{C} 12$ & $1.376(4)$ \\
\hline $\mathrm{O} 2-\mathrm{C} 21$ & $1.373(3)$ & $\mathrm{C} 13-\mathrm{C} 14$ & $1.378(4)$ \\
\hline $\mathrm{O} 2-\mathrm{C} 24$ & $1.421(3)$ & $\mathrm{C} 22-\mathrm{C} 23$ & $1.383(4)$ \\
\hline $\mathrm{C} 18-\mathrm{C} 23$ & $1.387(3)$ & $\mathrm{C} 16-\mathrm{C} 15$ & $1.387(4)$ \\
\hline $\mathrm{C} 18-\mathrm{C} 19$ & $1.394(3)$ & $\mathrm{C} 15-\mathrm{C} 14$ & $1.379(4)$ \\
\hline $\mathrm{C} 1-\mathrm{C} 2$ & $1.422(4)$ & $\mathrm{C} 4-\mathrm{C} 3$ & $1.405(4)$ \\
\hline $\mathrm{C} 1-\mathrm{C} 5$ & $1.425(4)$ & $\mathrm{C} 4-\mathrm{C} 5$ & $1.421(4)$ \\
\hline $\mathrm{C} 7-\mathrm{C} 6$ & $1.403(4)$ & $\mathrm{C} 7-\mathrm{C} 8$ & $1.410(4)$ \\
\hline \multicolumn{4}{|c|}{ Bond angles $[\mathrm{deg}]$} \\
\hline $\mathrm{C} 3-\mathrm{Fe} 1-\mathrm{C} 2$ & $40.79(10)$ & $\mathrm{C} 8-\mathrm{Fe} 1-\mathrm{C} 1$ & $152.56(11)$ \\
\hline $\mathrm{C} 3-\mathrm{Fe} 1-\mathrm{C} 10$ & $153.66(13)$ & $\mathrm{C} 5-\mathrm{Fe} 1-\mathrm{C} 1$ & $40.34(10)$ \\
\hline $\mathrm{C} 2-\mathrm{Fe} 1-\mathrm{C} 10$ & $164.75(12)$ & $\mathrm{C} 1-\mathrm{N} 1-\mathrm{C} 18$ & $124.0(2)$ \\
\hline $\mathrm{C} 3-\mathrm{Fe} 1-\mathrm{C} 4$ & $40.45(12)$ & $\mathrm{C} 1-\mathrm{N} 1-\mathrm{C} 11$ & $114.3(2)$ \\
\hline $\mathrm{C} 2-\mathrm{Fe} 1-\mathrm{C} 4$ & $68.27(11)$ & $\mathrm{C} 18-\mathrm{N} 1-\mathrm{C} 11$ & $117.4(2)$ \\
\hline $\mathrm{C} 10-\mathrm{Fe} 1-\mathrm{C} 4$ & $120.30(13)$ & $\mathrm{C} 21-\mathrm{O} 2-\mathrm{C} 24$ & $117.2(2)$ \\
\hline $\mathrm{C} 3-\mathrm{Fe} 1-\mathrm{C} 9$ & $119.25(12)$ & $\mathrm{C} 23-\mathrm{C} 18-\mathrm{C} 19$ & $117.4(2)$ \\
\hline $\mathrm{C} 2-\mathrm{Fe} 1-\mathrm{C} 9$ & $152.74(13)$ & $\mathrm{C} 23-\mathrm{C} 18-\mathrm{N} 1$ & $124.1(2)$ \\
\hline
\end{tabular}




\begin{tabular}{|c|c|c|c|}
\hline $\mathrm{C} 10-\mathrm{Fe} 1-\mathrm{C} 9$ & $40.45(13)$ & $\mathrm{C} 19-\mathrm{C} 18-\mathrm{N} 1$ & $118.5(2)$ \\
\hline $\mathrm{C} 4-\mathrm{Fe} 1-\mathrm{C} 9$ & $109.02(12)$ & $\mathrm{N} 1-\mathrm{C} 1-\mathrm{C} 2$ & $123.4(2)$ \\
\hline $\mathrm{C} 3-\mathrm{Fe} 1-\mathrm{C} 7$ & $126.54(12)$ & $\mathrm{N} 1-\mathrm{C} 1-\mathrm{C} 5$ & $129.1(2)$ \\
\hline $\mathrm{C} 2-\mathrm{Fe} 1-\mathrm{C} 7$ & $107.12(11)$ & $\mathrm{C} 2-\mathrm{C} 1-\mathrm{C} 5$ & $107.4(2)$ \\
\hline $\mathrm{C} 10-\mathrm{Fe} 1-\mathrm{C} 7$ & $67.95(12)$ & $\mathrm{N} 1-\mathrm{C} 1-\mathrm{Fe} 1$ & $130.19(17)$ \\
\hline $\mathrm{C} 4-\mathrm{Fe} 1-\mathrm{C} 7$ & $164.45(13)$ & $\mathrm{C} 2-\mathrm{C} 1-\mathrm{Fe} 1$ & $68.32(14)$ \\
\hline $\mathrm{C} 9-\mathrm{Fe} 1-\mathrm{C} 7$ & $67.84(12)$ & $\mathrm{C} 5-\mathrm{C} 1-\mathrm{Fe} 1$ & $69.40(15)$ \\
\hline $\mathrm{C} 3-\mathrm{Fe} 1-\mathrm{C} 6$ & $163.97(12)$ & $\mathrm{C} 6-\mathrm{C} 7-\mathrm{C} 8$ & $108.2(3)$ \\
\hline $\mathrm{C} 2-\mathrm{Fe} 1-\mathrm{C} 6$ & $126.45(11)$ & $\mathrm{C} 6-\mathrm{C} 7-\mathrm{Fe} 1$ & $69.89(16)$ \\
\hline $\mathrm{C} 10-\mathrm{Fe} 1-\mathrm{C} 6$ & $40.64(12)$ & $\mathrm{C} 8-\mathrm{C} 7-\mathrm{Fe} 1$ & $69.96(17)$ \\
\hline $\mathrm{C} 4-\mathrm{Fe} 1-\mathrm{C} 6$ & $154.30(13)$ & $\mathrm{C} 16-\mathrm{C} 11-\mathrm{C} 12$ & $119.5(2)$ \\
\hline $\mathrm{C} 9-\mathrm{Fe} 1-\mathrm{C} 6$ & $68.03(12)$ & $\mathrm{C} 16-\mathrm{C} 11-\mathrm{N} 1$ & $120.4(2)$ \\
\hline $\mathrm{C} 7-\mathrm{Fe} 1-\mathrm{C} 6$ & $40.23(11)$ & $\mathrm{C} 12-\mathrm{C} 11-\mathrm{N} 1$ & $119.9(2)$ \\
\hline $\mathrm{C} 3-\mathrm{Fe} 1-\mathrm{C} 8$ & $107.69(13)$ & $\mathrm{C} 14-\mathrm{O} 1-\mathrm{C} 17$ & $116.8(3)$ \\
\hline $\mathrm{C} 2-\mathrm{Fe} 1-\mathrm{C} 8$ & $118.47(11)$ & $\mathrm{C} 9-\mathrm{C} 10-\mathrm{Fe} 1$ & $69.86(17)$ \\
\hline $\mathrm{C} 10-\mathrm{Fe} 1-\mathrm{C} 8$ & $67.85(12)$ & $\mathrm{C} 6-\mathrm{C} 10-\mathrm{Fe} 1$ & $69.82(16)$ \\
\hline $\mathrm{C} 4-\mathrm{Fe} 1-\mathrm{C} 8$ & $127.47(12)$ & $\mathrm{C} 12-\mathrm{C} 13-\mathrm{C} 14$ & $119.6(2)$ \\
\hline $\mathrm{C} 9-\mathrm{Fe} 1-\mathrm{C} 8$ & $40.20(12)$ & $\mathrm{C} 19-\mathrm{C} 20-\mathrm{C} 21$ & $120.9(3)$ \\
\hline $\mathrm{C} 7-\mathrm{Fe} 1-\mathrm{C} 8$ & $40.41(11)$ & $\mathrm{C} 13-\mathrm{C} 12-\mathrm{C} 11$ & $120.5(3)$ \\
\hline $\mathrm{C} 6-\mathrm{Fe} 1-\mathrm{C} 8$ & $67.84(12)$ & $\mathrm{C} 21-\mathrm{C} 22-\mathrm{C} 23$ & $120.4(2)$ \\
\hline $\mathrm{C} 3-\mathrm{Fe} 1-\mathrm{C} 5$ & $68.16(12)$ & $\mathrm{C} 9-\mathrm{C} 8-\mathrm{C} 7$ & $108.0(3)$ \\
\hline $\mathrm{C} 2-\mathrm{Fe} 1-\mathrm{C} 5$ & $68.13(11)$ & $\mathrm{C} 9-\mathrm{C} 8-\mathrm{Fe} 1$ & $69.68(17)$ \\
\hline $\mathrm{C} 10-\mathrm{Fe} 1-\mathrm{C} 5$ & $109.30(12)$ & $\mathrm{C} 7-\mathrm{C} 8-\mathrm{Fe} 1$ & $69.63(16)$ \\
\hline $\mathrm{C} 4-\mathrm{Fe} 1-\mathrm{C} 5$ & $40.57(11)$ & $\mathrm{C} 11-\mathrm{C} 16-\mathrm{C} 15$ & $120.6(3)$ \\
\hline $\mathrm{C} 9-\mathrm{Fe} 1-\mathrm{C} 5$ & $128.55(12)$ & $\mathrm{C} 14-\mathrm{C} 15-\mathrm{C} 16$ & $119.3(3)$ \\
\hline $\mathrm{C} 7-\mathrm{Fe} 1-\mathrm{C} 5$ & $153.13(12)$ & $\mathrm{C} 3-\mathrm{C} 4-\mathrm{C} 5$ & $108.3(2)$ \\
\hline $\mathrm{C} 6-\mathrm{Fe} 1-\mathrm{C} 5$ & $119.96(12)$ & $\mathrm{C} 3-\mathrm{C} 4-\mathrm{Fe} 1$ & $69.41(16)$ \\
\hline $\mathrm{C} 8-\mathrm{Fe} 1-\mathrm{C} 5$ & $165.55(12)$ & $\mathrm{C} 5-\mathrm{C} 4-\mathrm{Fe} 1$ & $70.59(15)$ \\
\hline $\mathrm{C} 3-\mathrm{Fe} 1-\mathrm{C} 1$ & $68.23(11)$ & $\mathrm{C} 22-\mathrm{C} 23-\mathrm{C} 18$ & $121.3(2)$ \\
\hline $\mathrm{C} 2-\mathrm{Fe} 1-\mathrm{C} 1$ & $40.51(10)$ & $\mathrm{O} 1-\mathrm{C} 14-\mathrm{C} 13$ & $115.3(3)$ \\
\hline $\mathrm{C} 10-\mathrm{Fe} 1-\mathrm{C} 1$ & $127.92(12)$ & $\mathrm{C} 8-\mathrm{Fe} 1-\mathrm{C} 1$ & $152.56(11)$ \\
\hline $\mathrm{C} 4-\mathrm{Fe} 1-\mathrm{C} 1$ & $68.06(11)$ & $\mathrm{C} 5-\mathrm{Fe} 1-\mathrm{C} 1$ & $40.34(10)$ \\
\hline $\mathrm{C} 9-\mathrm{Fe} 1-\mathrm{C} 1$ & $165.82(12)$ & $\mathrm{C} 1-\mathrm{N} 1-\mathrm{C} 18$ & $124.0(2)$ \\
\hline
\end{tabular}


$\mathrm{C} 7-\mathrm{Fe} 1-\mathrm{C} 1$

$118.78(11)$

$\mathrm{C} 1-\mathrm{N} 1-\mathrm{C} 11$

$114.3(2)$

$\mathrm{C} 6-\mathrm{Fe} 1-\mathrm{C} 1$

$108.18(11)$
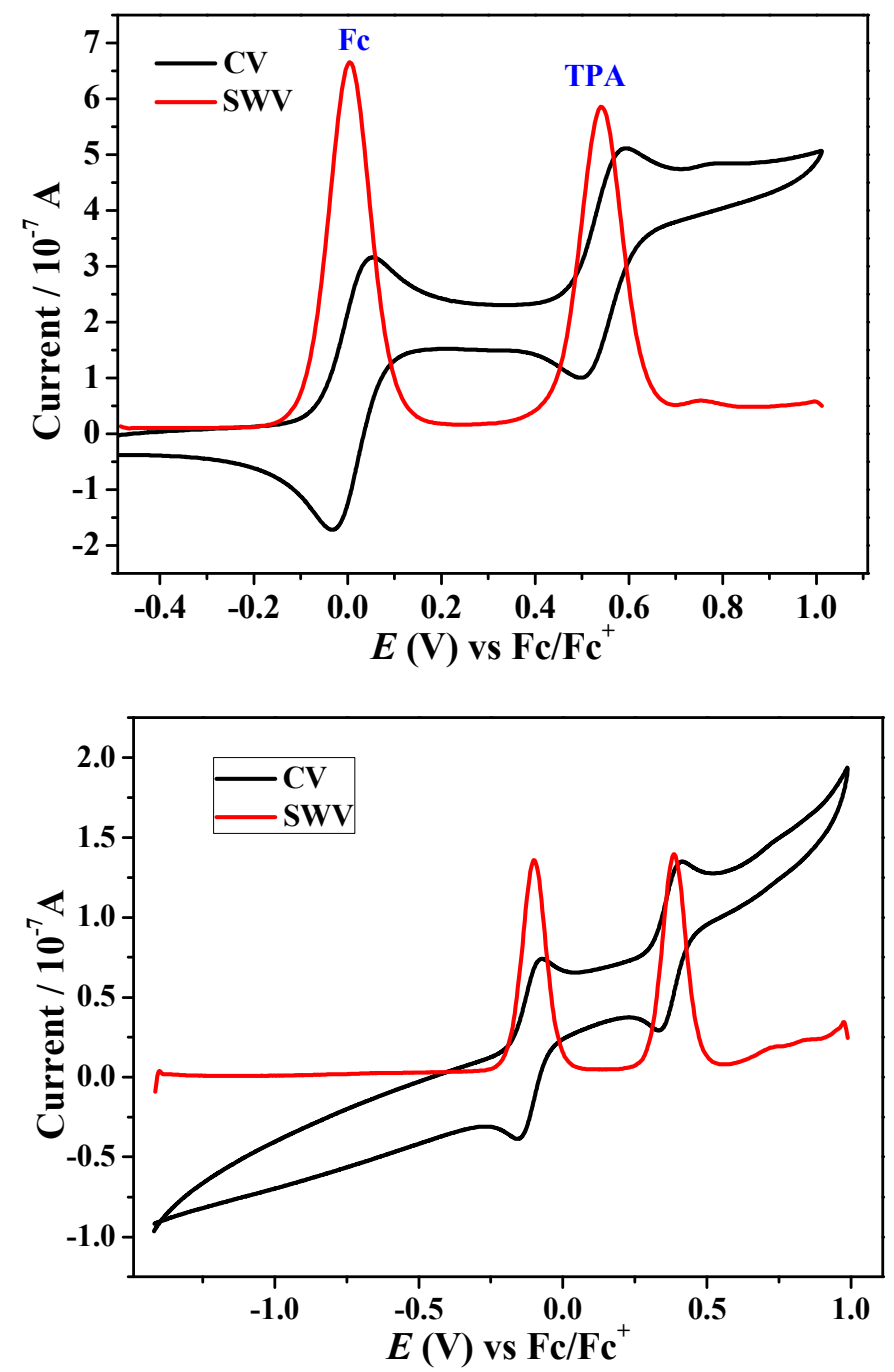

Figure S1. Cyclic voltammograms (CV, at $v=50 \mathrm{mV} \mathrm{s}^{-1}$; black line) and corresponding square-wave voltammograms ( $\mathrm{SWV}$, at $f=10 \mathrm{~Hz}$ and $t_{\mathrm{p}}=25 \mathrm{mV}$; red line) of TPA (top, with ferrocene present as the internal standard), and M4TPPD (bottom) in $\mathrm{CH}_{2} \mathrm{Cl}_{2} / n-\mathrm{Bu}_{4} \mathrm{NPF} 6$. 


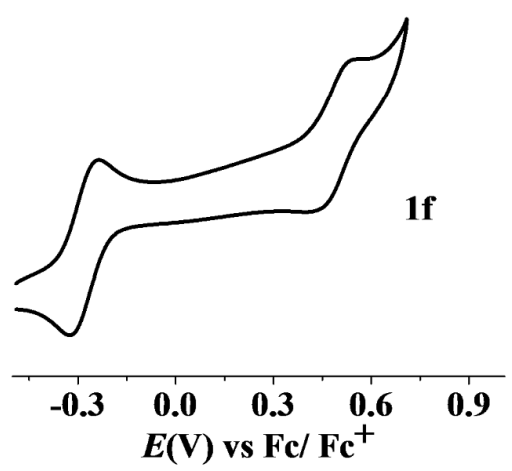

Figure S2. The curtailed two-anodic-step cyclic voltammogram (CV) of $\mathbf{1 f}$ in $\mathrm{CH}_{2} \mathrm{Cl}_{2} / n$-Bu4NPF6 at $v=50 \mathrm{mV} \mathrm{s}^{-1}$.

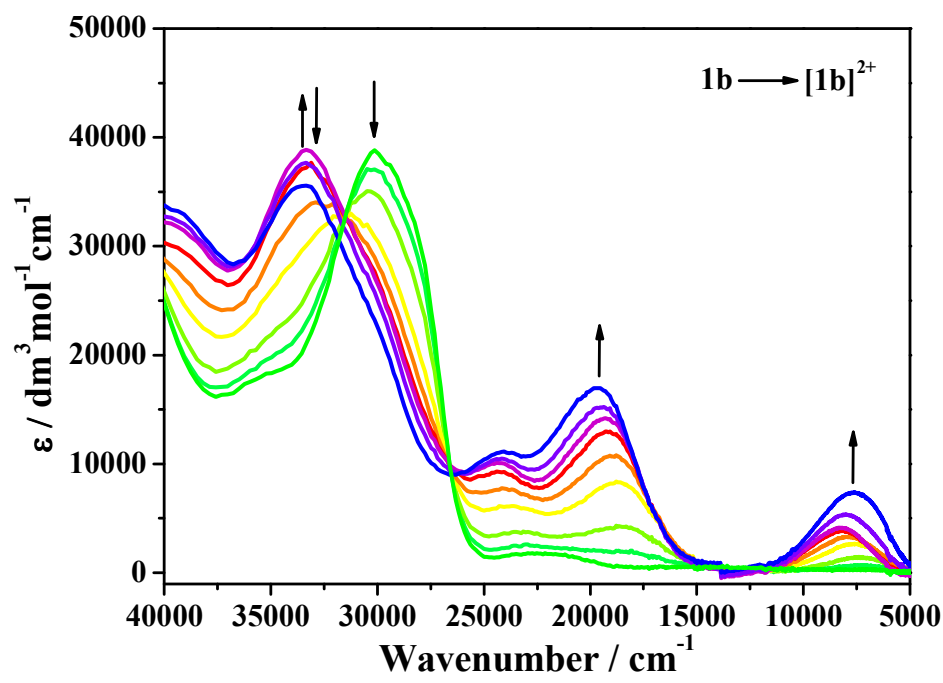

Figure S3. Changes in UV-vis-NIR absorption spectra recorded during the oxidation of complex 1b to $[\mathbf{1 b}]^{2+}$ in $\mathrm{CH}_{2} \mathrm{Cl}_{2} / 10^{-1} \mathrm{M} n-\mathrm{Bu}_{4} \mathrm{NPF}_{6}$ at $298 \mathrm{~K}$ within an OTTLE cell. The intermediate absorption of $[\mathbf{1 b}]^{+}$is poorly resolved due to pronounced redox disproportionation of the monocation. 

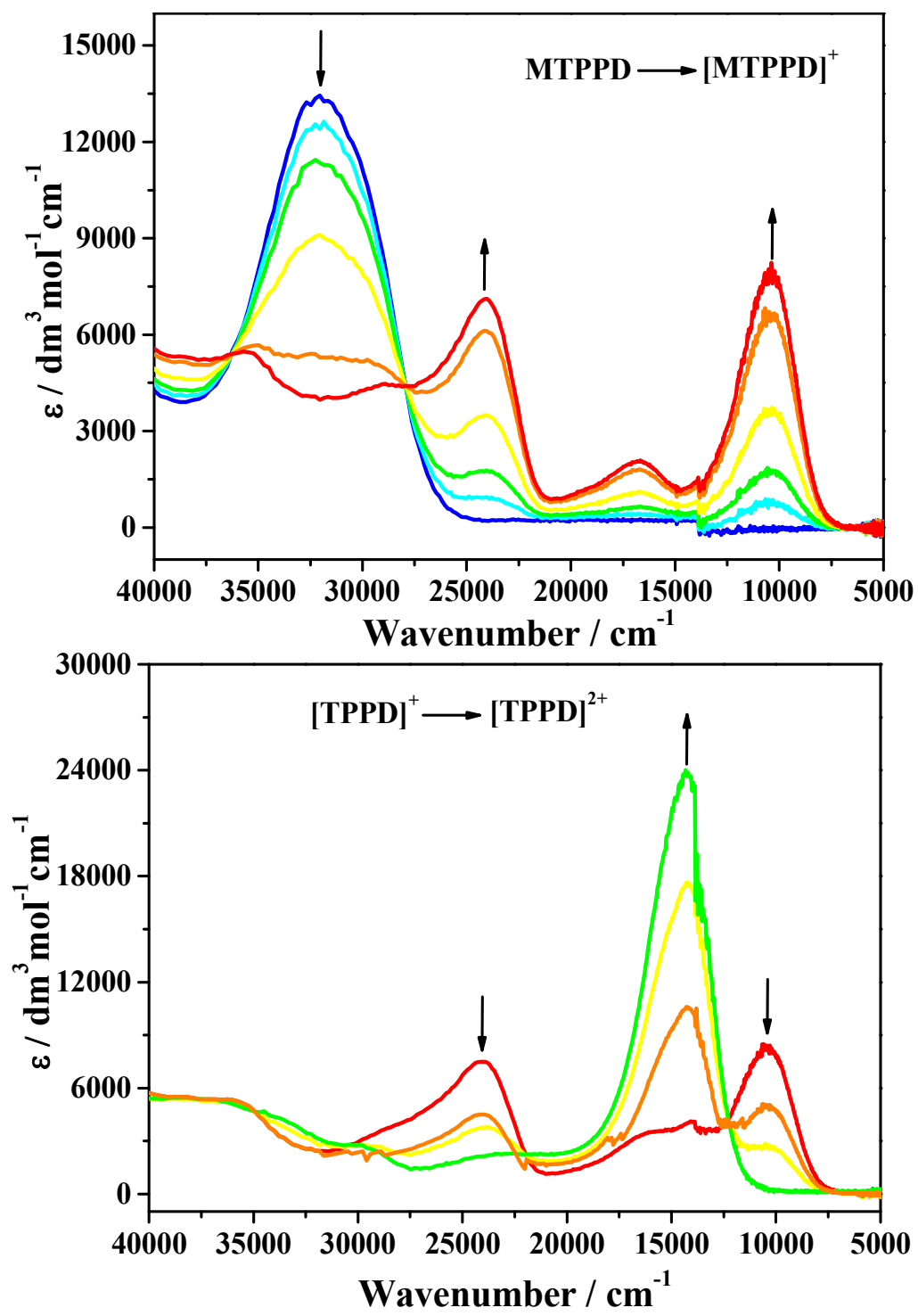

Figure S4. Changes in UV-vis-NIR absorption spectra recorded during the oxidation of reference compound MTPPD to [MTPPD] $]^{+}$(top) and [MTPPD $]^{2+}$ (bottom) in $\mathrm{CH}_{2} \mathrm{Cl}_{2} / 10^{-1} \mathrm{M} n$ - $\mathrm{Bu}_{4} \mathrm{NPF}_{6}$ at $298 \mathrm{~K}$ within an OTTLE cell. 


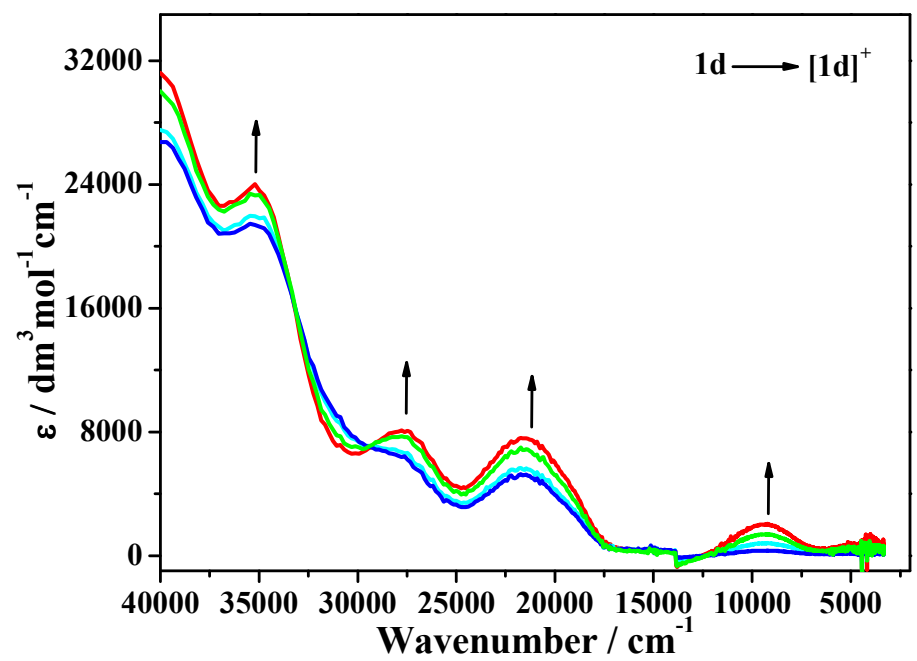

Figure S5. UV-vis-NIR spectral changes recorded during the reversible Fc-localized oxidation of complex 1d to $[\mathbf{1 d}]^{+}$in $\mathrm{CH}_{2} \mathrm{Cl}_{2} / 10^{-1} \mathrm{M} n-\mathrm{Bu}_{4} \mathrm{NPF}_{6}$ at $298 \mathrm{~K}$ within an OTTLE cell.

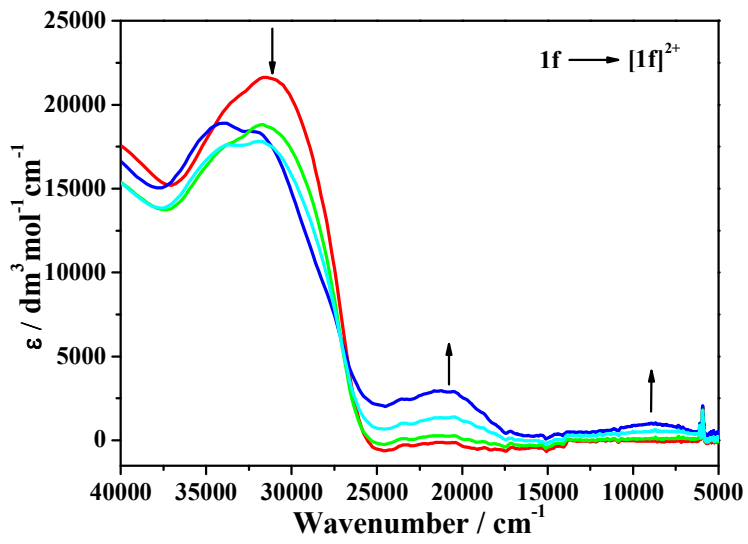

Figure S6. Changes in UV-vis-NIR absorption recorded during the unresolved bielectronic oxidation of dinuclear complex 1 ff to $[\mathbf{1 f}]^{2+}$ in $\mathrm{CH}_{2} \mathrm{Cl}_{2} / 10^{-1} \mathrm{M} n-\mathrm{Bu}_{4} \mathrm{NPF}_{6}$ at $298 \mathrm{~K}$ within an OTTLE cell. The subsequent oxidation to $[\mathbf{1} f]^{3+}$ was complicated by low solubility of the ultimate product. 


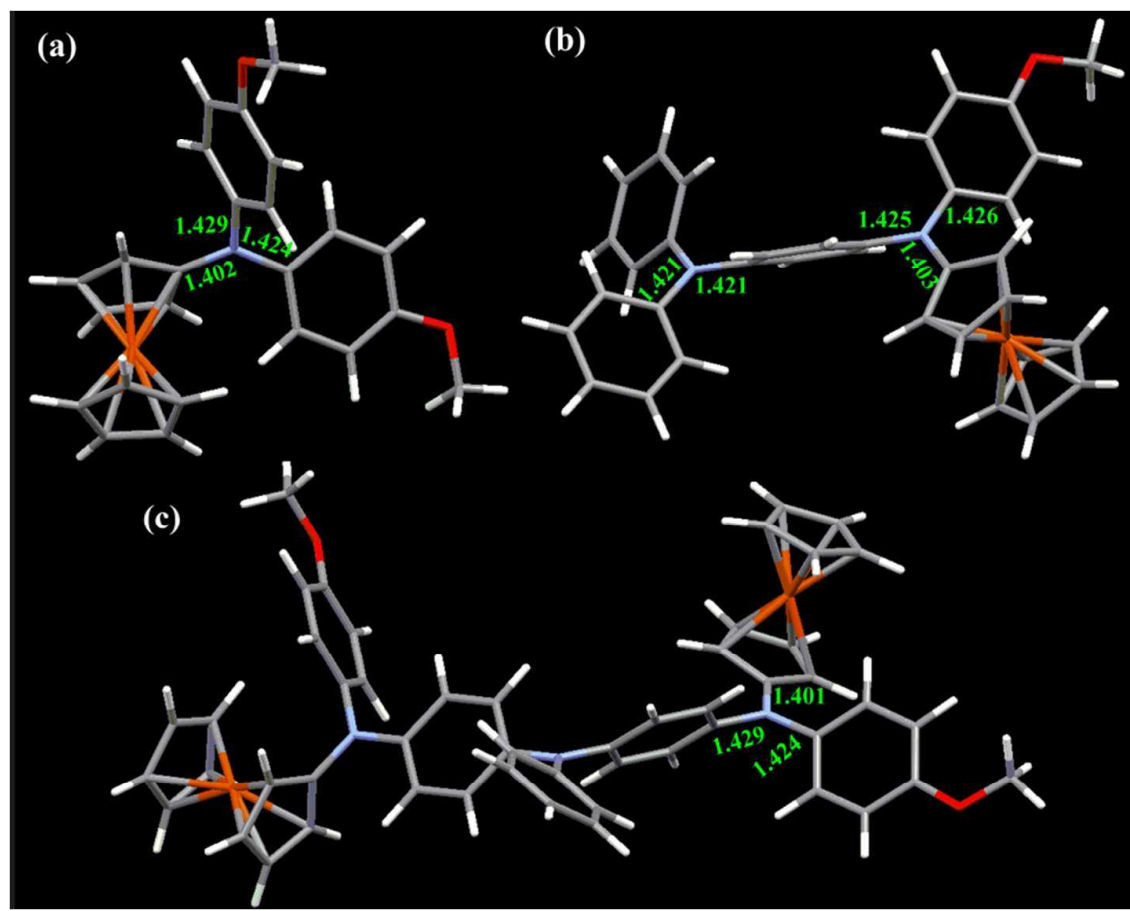

Figure S7. The DFT-optimized geometric structures of $\mathbf{1 d}(\mathrm{a}), \mathbf{1 e}(\mathrm{b})$ and $\mathbf{1 f}(\mathrm{c})$.

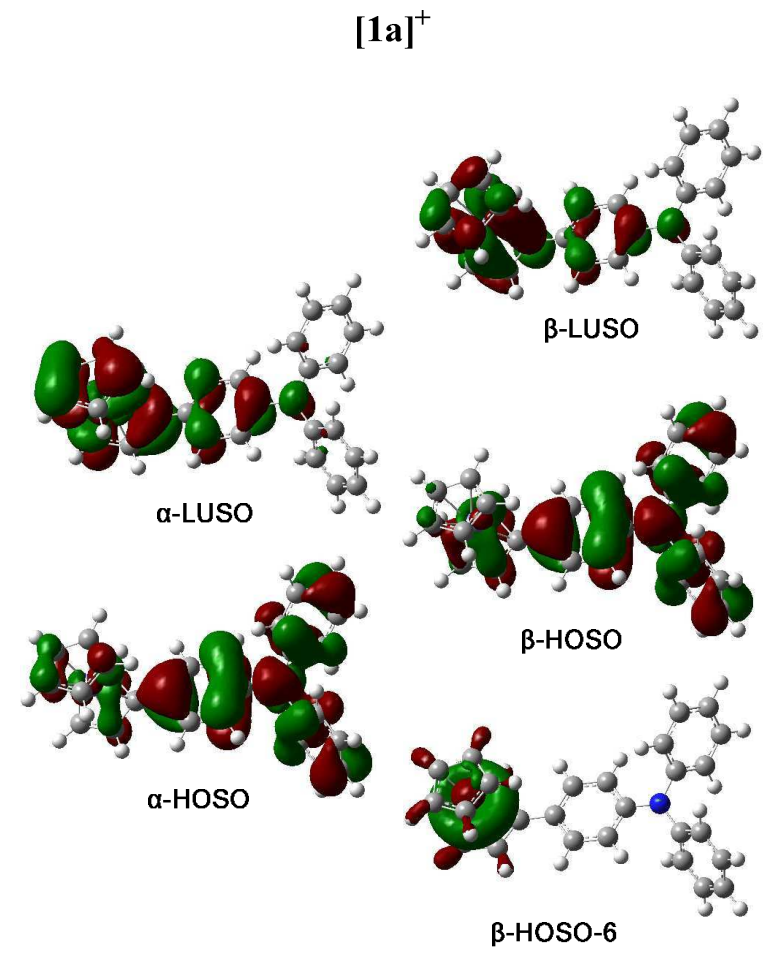

Figure S8. Spin orbitals involved in the major electronic excitations of $[\mathbf{1 a}]^{+}$. B3LYP /6-31G* $(\mathrm{Fe}$ : Lanl2DZ) /CPCM $/ \mathrm{CH}_{2} \mathrm{Cl}_{2}$. 


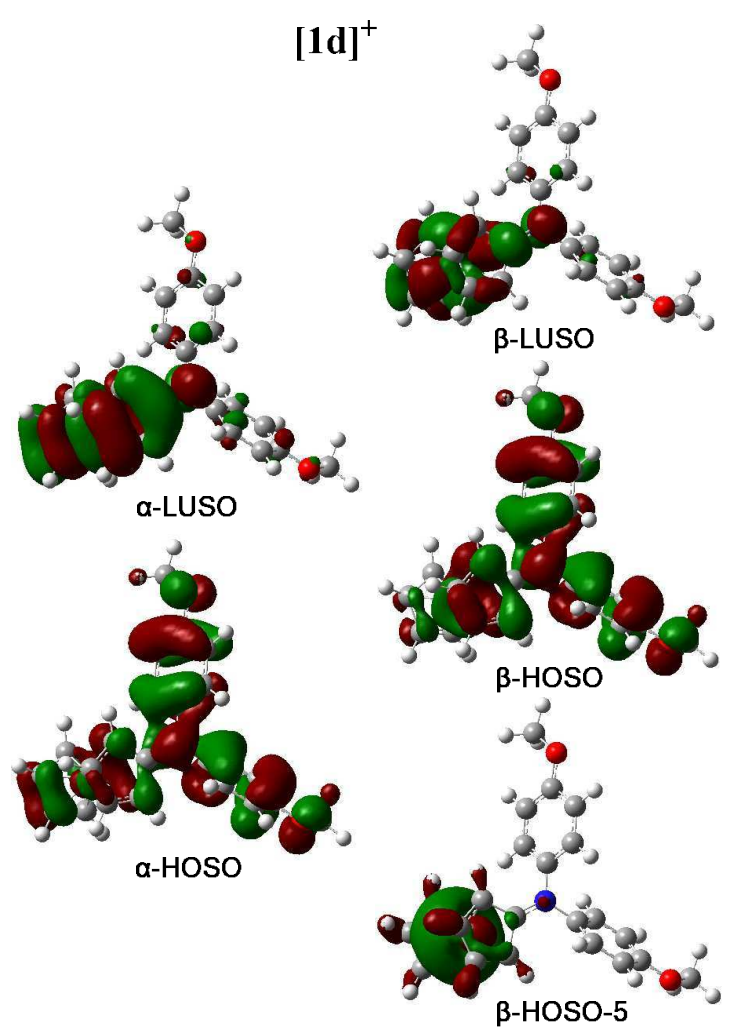

Figure S9. Spin orbitals involved in the major electronic excitations of [1d $]^{+}$. B3LYP /6-31G* (Fe: Lanl2DZ) /CPCM $/ \mathrm{CH}_{2} \mathrm{Cl}_{2}$. 

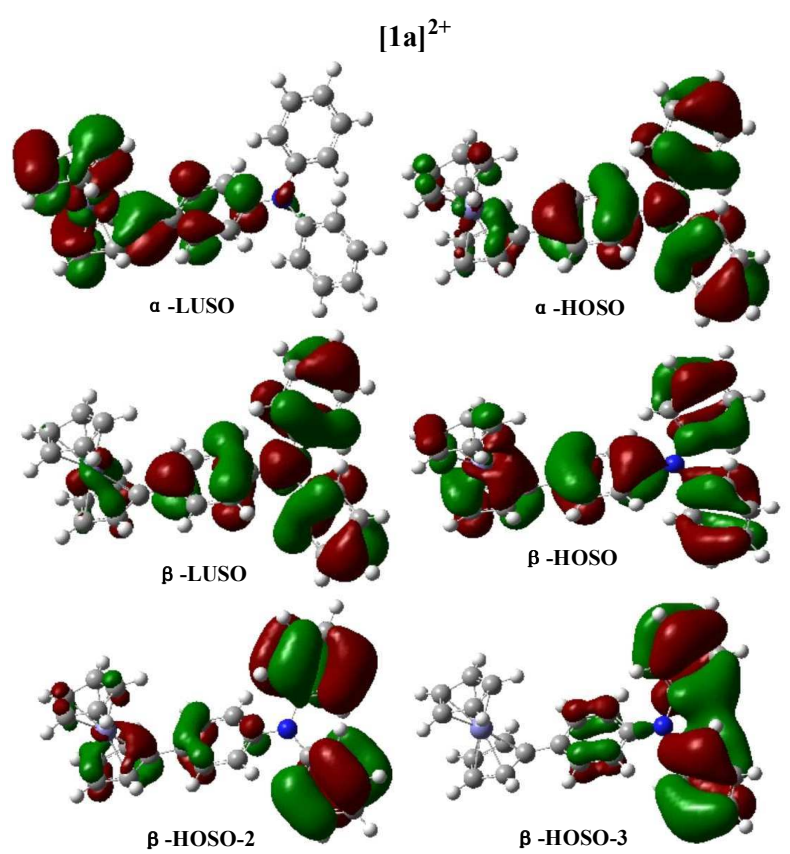

Figure S10. Spin orbitals involved in the major electronic excitations of $[\mathbf{1 a}]^{2+}$ (biradical state). B3LYP /6-31G* (Fe: Lanl2DZ) /CPCM / $\mathrm{CH}_{2} \mathrm{Cl}_{2}$.

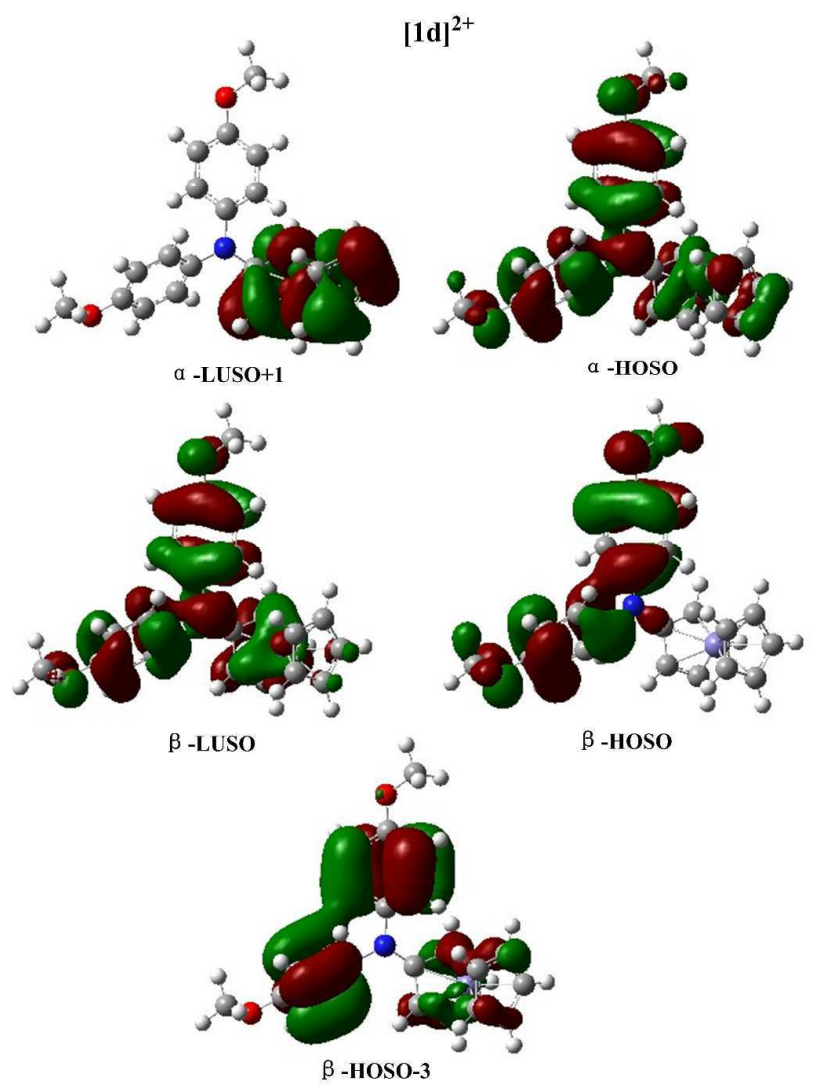

Figure S11. Spin orbitals involved in the major electronic excitations of $[\mathbf{1 d}]^{2+}$ (biradical state). 
B3LYP /6-31G* (Fe: Lanl2DZ) /CPCM / $\mathrm{CH}_{2} \mathrm{Cl}_{2}$.
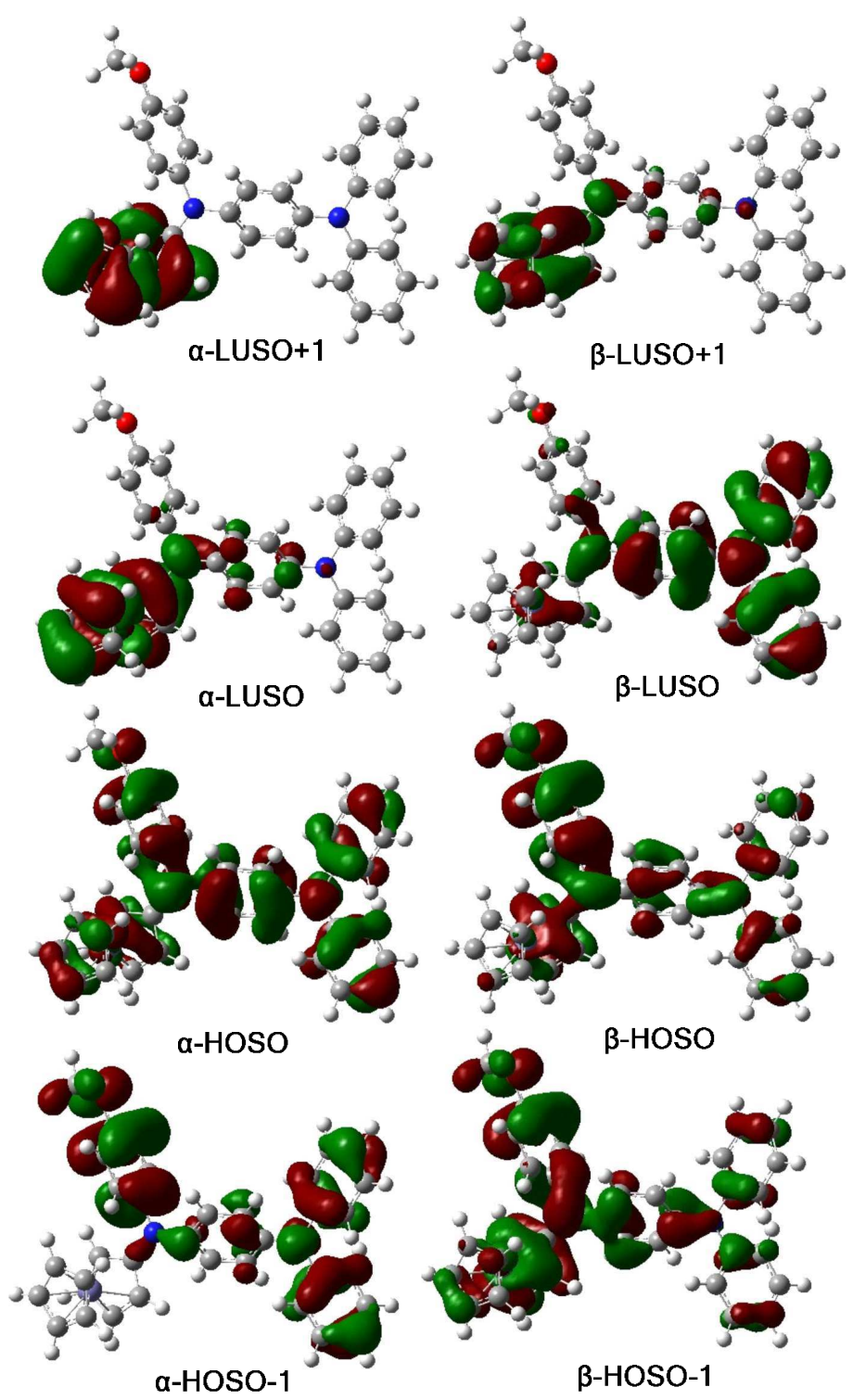

Figure S12. Frontier spin orbitals of $[1 \mathbf{e}]^{2+}$ (biradical state). B3LYP /6-31G* (Fe: Lanl2DZ) $/ \mathrm{CPCM} / \mathrm{CH}_{2} \mathrm{Cl}_{2}$. 


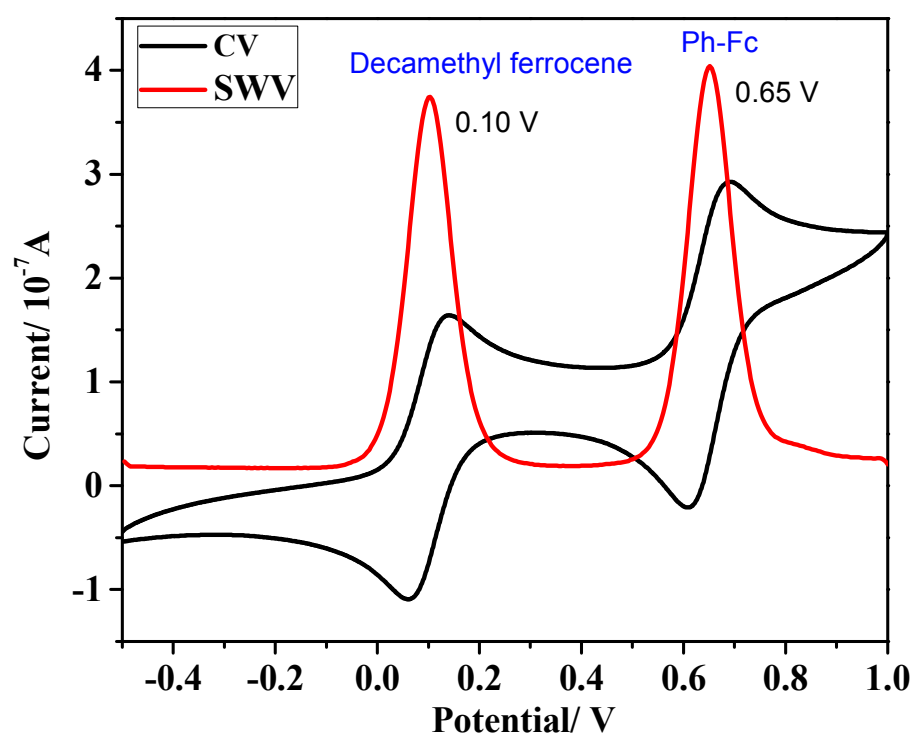

Figure S13. The cyclic voltammogram $\left(\mathrm{CV}\right.$, black line; $\left.v=50 \mathrm{mV} \mathrm{s}^{-1}\right)$ and the corresponding square-wave voltammogram ( $\mathrm{SWV}$, red line; at $f=10 \mathrm{~Hz}$ and $t_{\mathrm{p}}=25 \mathrm{mV}$ ) of reference phenylferrocene, $\mathrm{Ph}-\mathrm{Fc}$, in $\mathrm{CH}_{2} \mathrm{Cl}_{2} / n-\mathrm{Bu}_{4} \mathrm{NPF}_{6}$. The oxidation potential of $\mathrm{Ph}-\mathrm{Fc}$ is $E_{1 / 2}=+0.04 \mathrm{~V}$ vs ferrocene/ferrocenium $\left(\mathrm{Fc} / \mathrm{Fc}^{+}\right)$. The electronic absorption of $[\mathrm{Ph}-\mathrm{Fc}]^{+}$is presented in Figure S14.

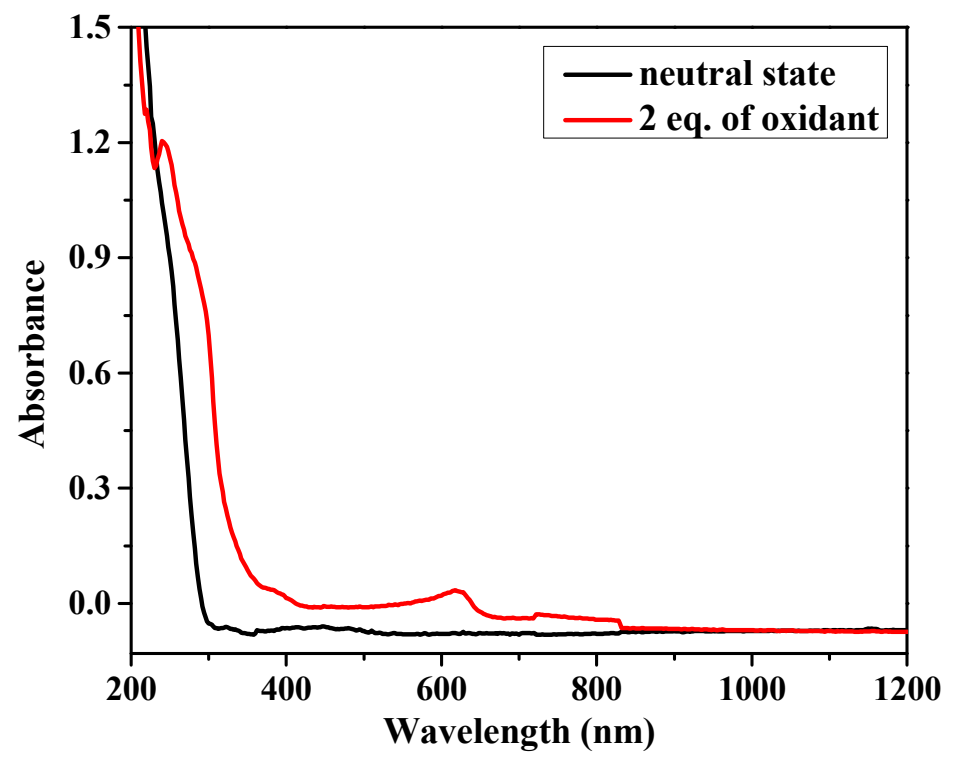

Figure S14. Electronic absorption spectra of $10^{-2} \mathrm{M}$ Ph-Fc (black line) and $[\mathrm{Ph}-\mathrm{Fc}]^{+}$(red line) obtained by chemical oxidation with $\mathrm{AgPF}_{6}$ in $\mathrm{CH}_{2} \mathrm{Cl}_{2}$ at $298 \mathrm{~K}$. The simulated spectra of $[\mathrm{Ph}-\mathrm{Fc}]^{+}$ and corresponding electronic transitions obtained with TD-DFT methods are depicted in Figures S15-S17. 


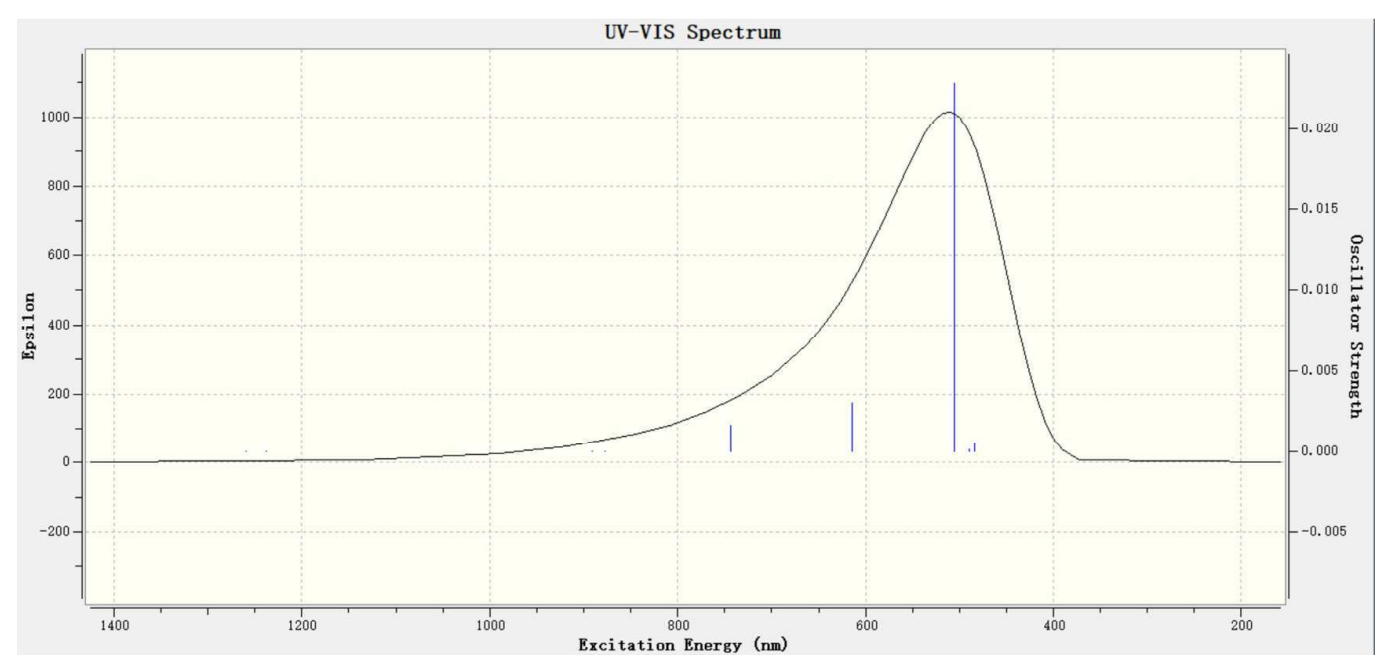

Figure S15. Simulated electronic absorption of $[\mathrm{Ph}-\mathrm{Fc}]^{+}$. B3LYP/6-31G*/CPCM $/ \mathrm{CH}_{2} \mathrm{Cl}_{2}$.

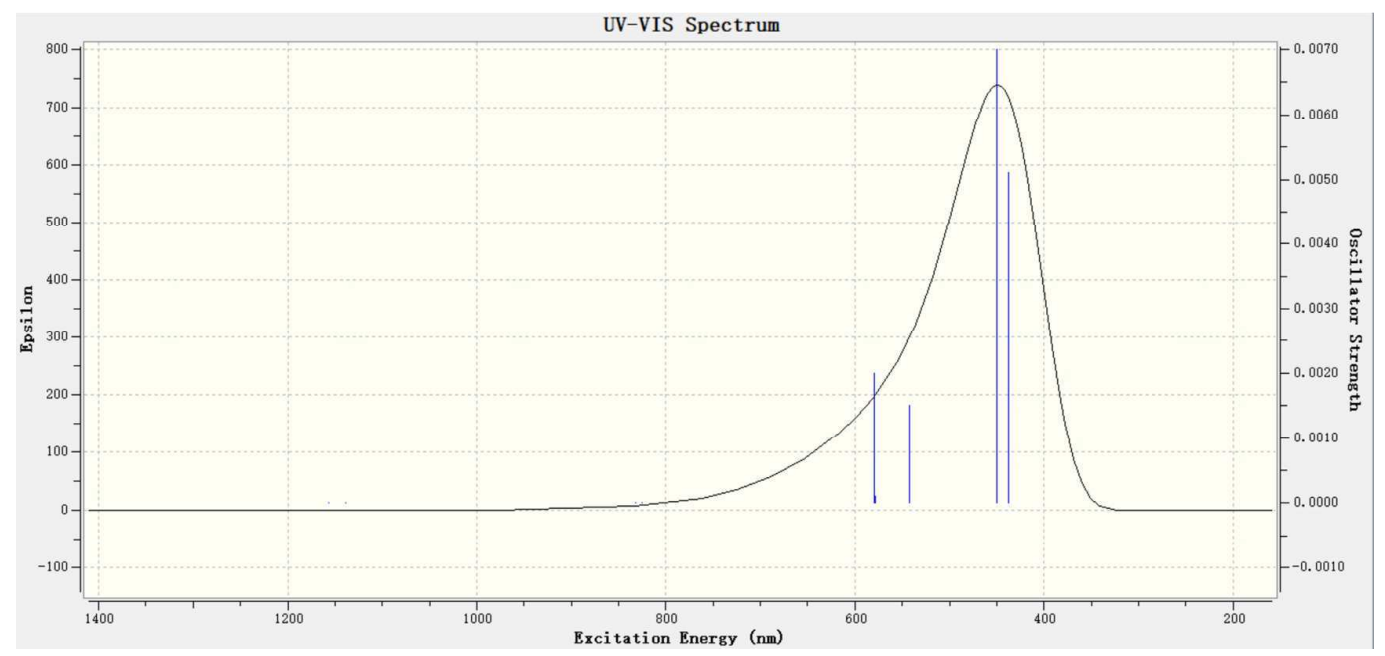

Figure S16. Simulated electronic absorption of $[\mathrm{Ph}-\mathrm{Fc}]^{+}$; CAM-B3LYP/6-31G*/CPCM $/ \mathrm{CH}_{2} \mathrm{Cl}_{2}$. 


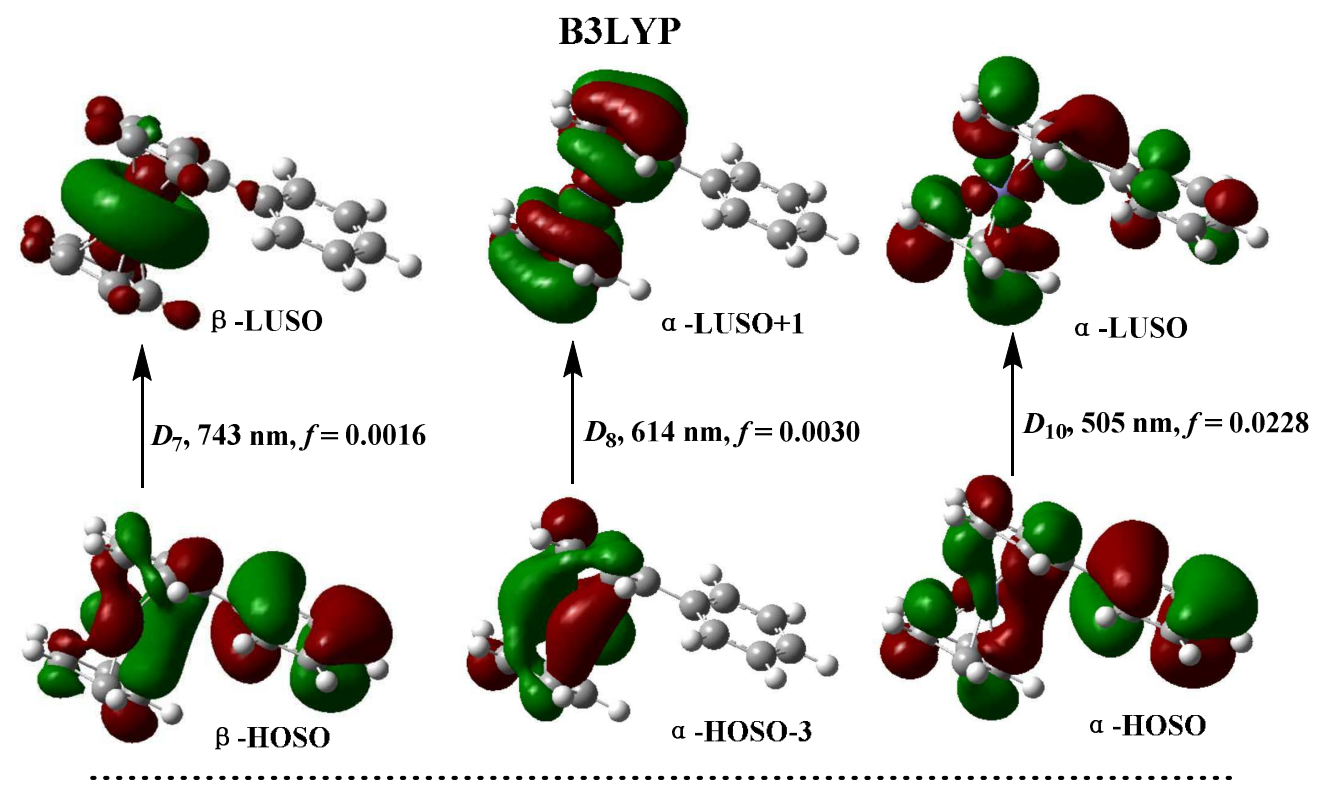

CAM-B3LYP

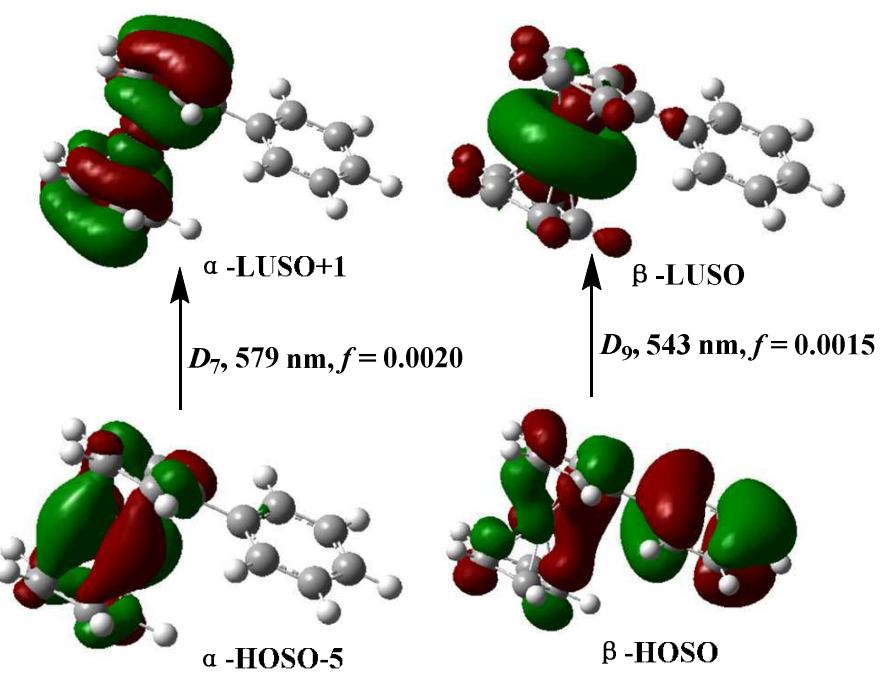

Figure S17. Spin orbitals involved in the plausible calculated visible electronic excitations of $[\mathrm{Ph}-\mathrm{Fc}]^{+}$(see Figures S15 and S16). A better agreement with the experimental visible absorption of the cationic complex has been reached with the B3LYP method.

\section{NMR Spectra}



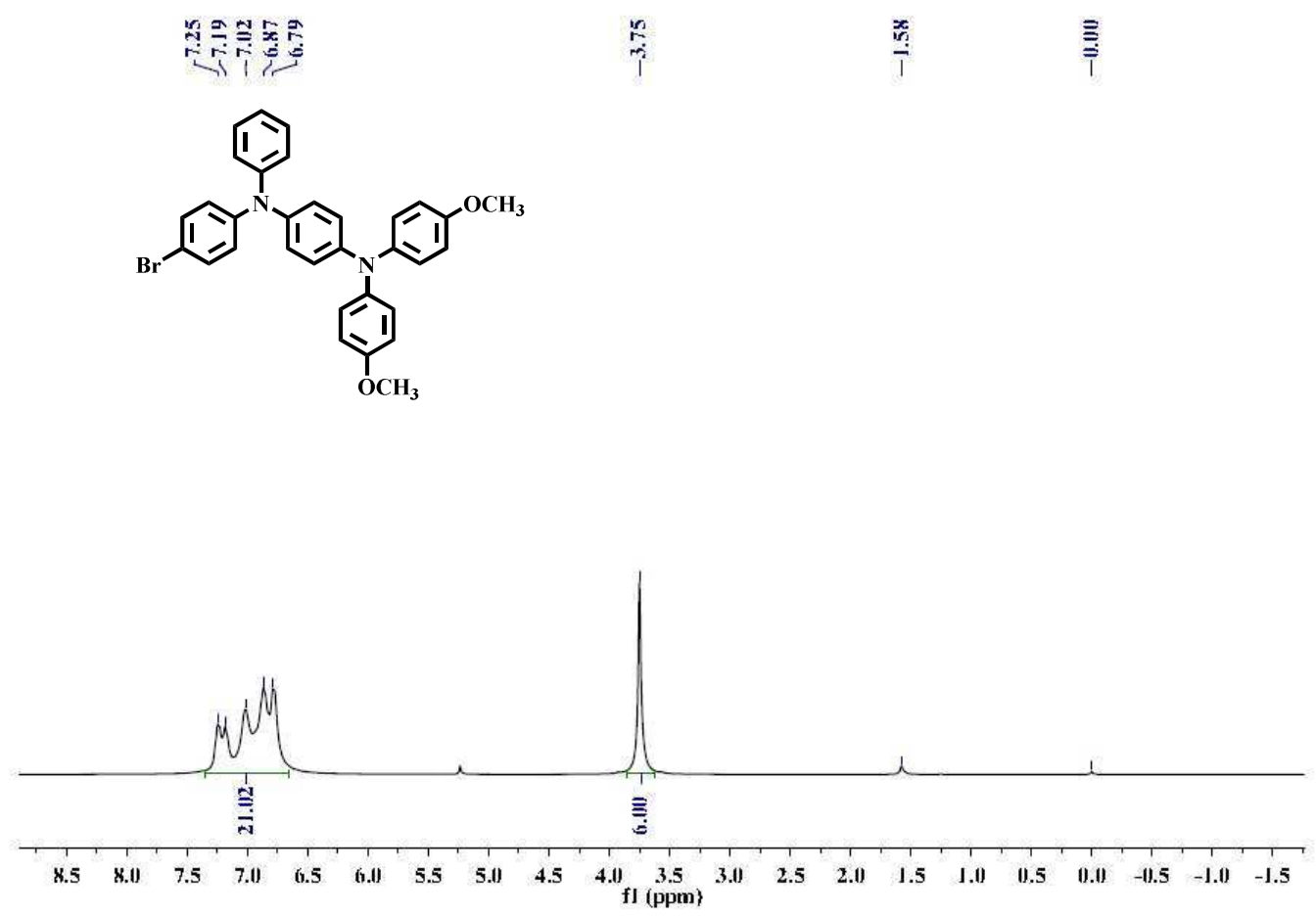

Figure S18. ${ }^{1} \mathrm{H}$ NMR spectrum $\left(400 \mathrm{MHz}, \mathrm{CDCl}_{3}\right)$ of $\mathbf{2 c}$.

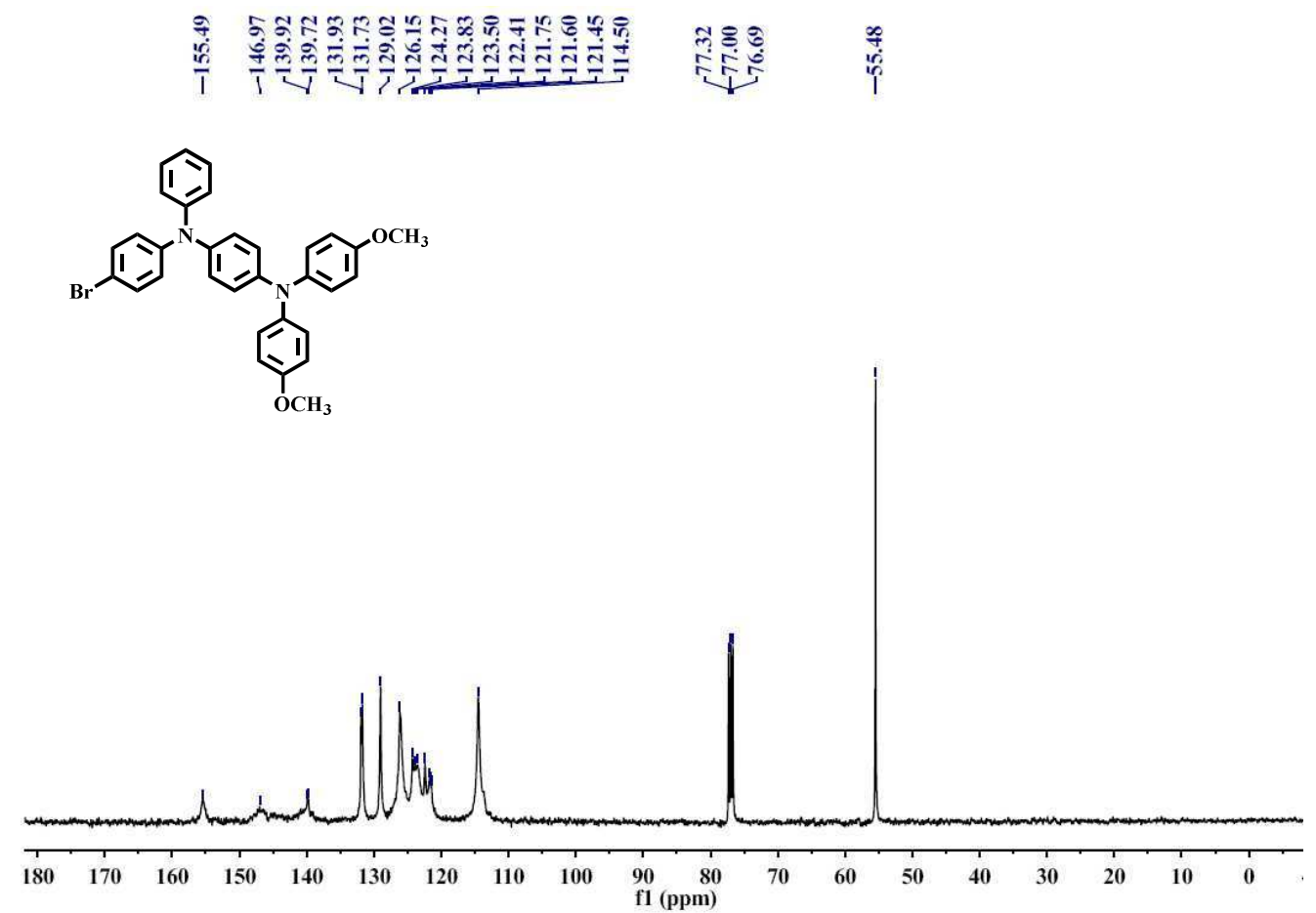

Figure S19. ${ }^{13} \mathrm{C}$ NMR spectrum $\left(100 \mathrm{MHz}, \mathrm{CDCl}_{3}\right)$ of $\mathbf{2 c}$. 


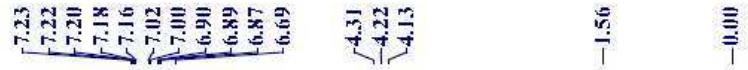

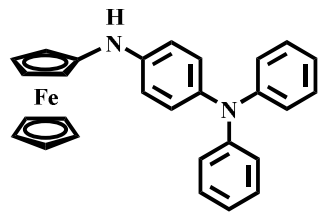

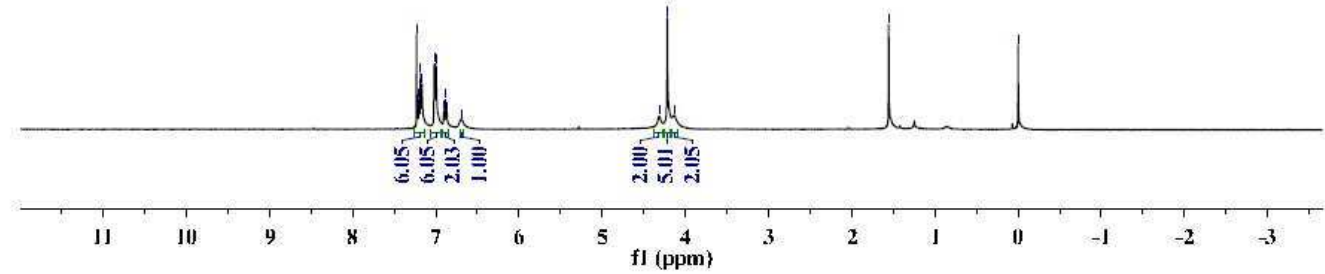

Figure S20. ${ }^{1} \mathrm{H}$ NMR spectrum $\left(400 \mathrm{MHz}, \mathrm{CDCl}_{3}\right)$ of $\mathbf{2 e}$.
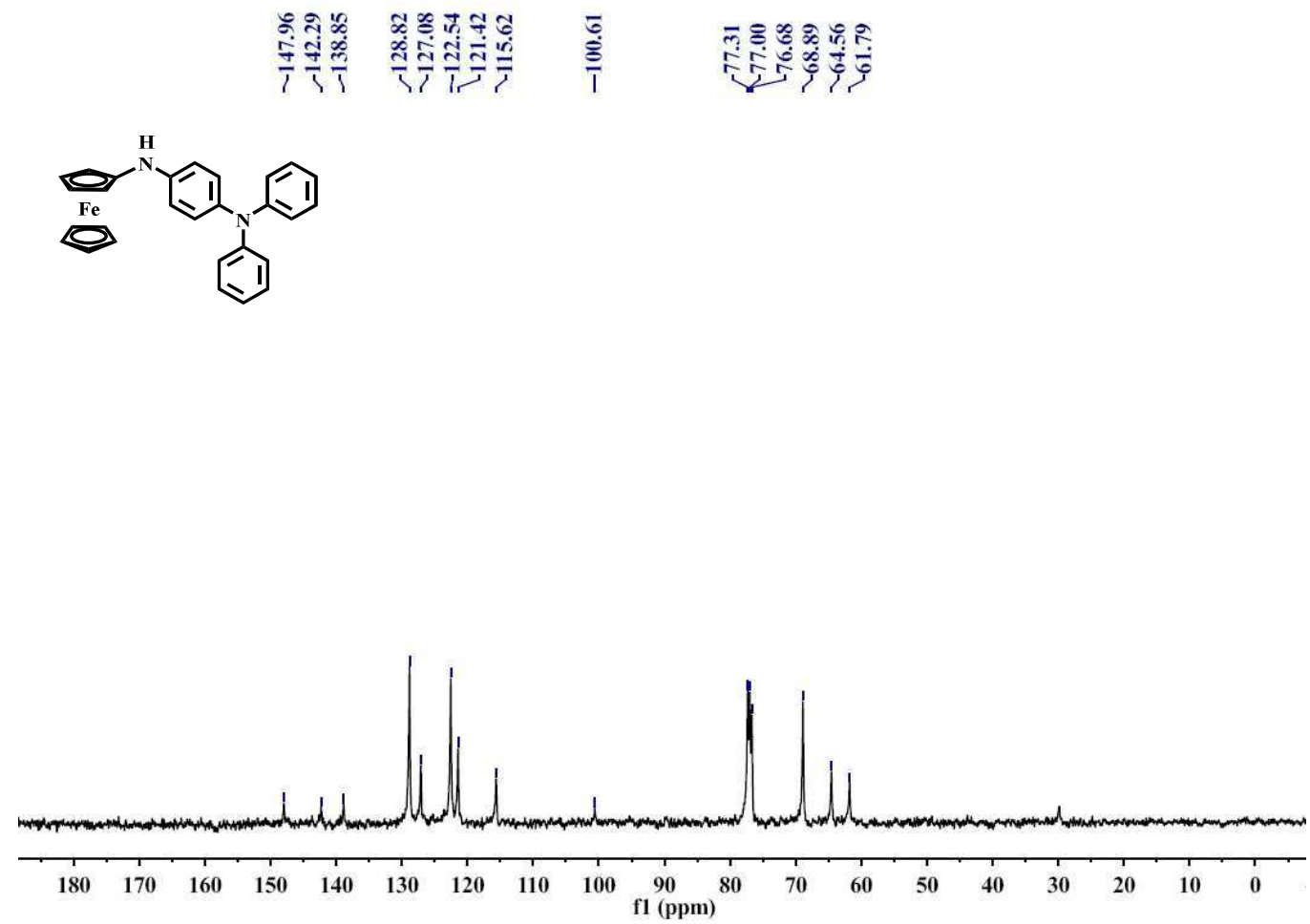

Figure S21. ${ }^{13} \mathrm{C}$ NMR spectrum $\left(100 \mathrm{MHz}, \mathrm{CDCl}_{3}\right)$ of $\mathbf{2 e}$. 


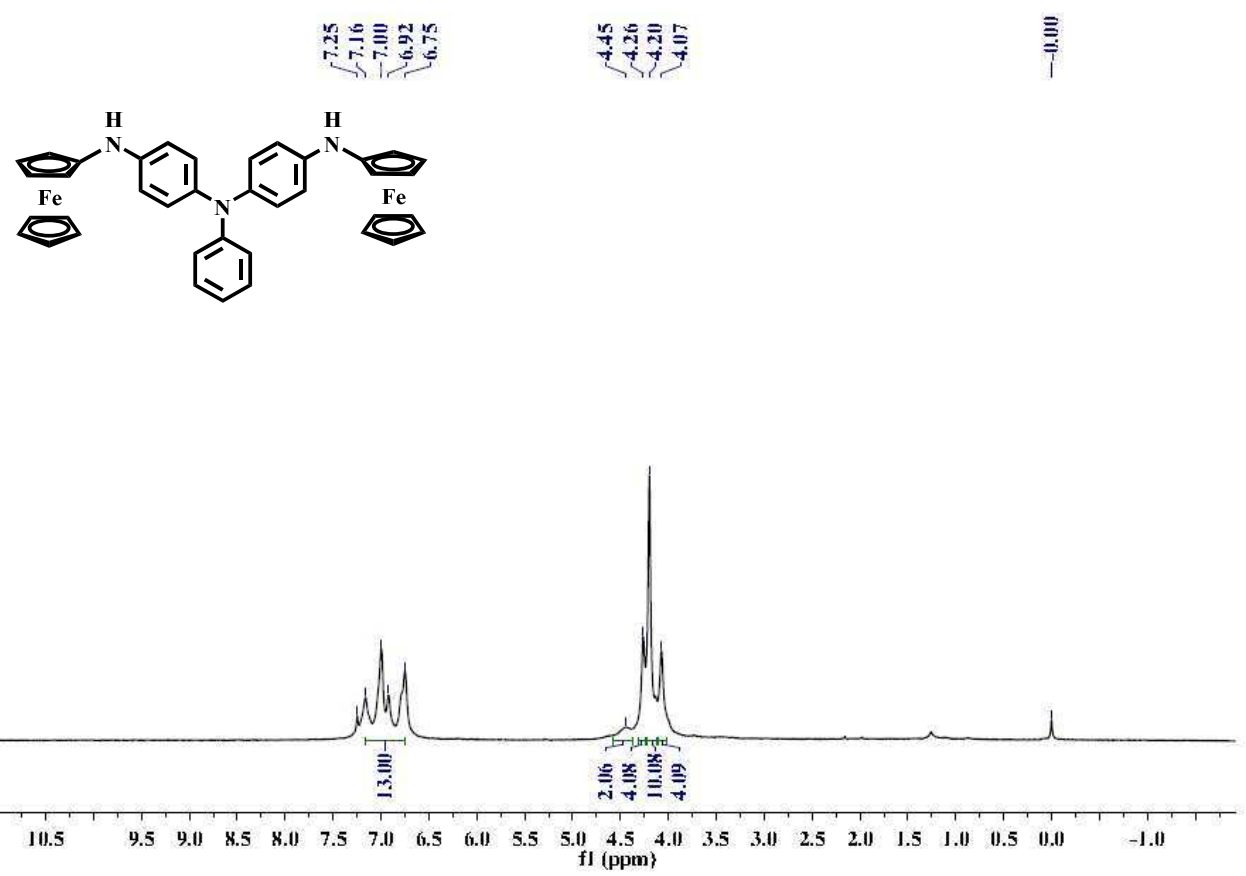

Figure S22. ${ }^{1} \mathrm{H}$ NMR spectrum $\left(600 \mathrm{MHz}, \mathrm{CDCl}_{3}\right)$ of $\mathbf{2 f}$.

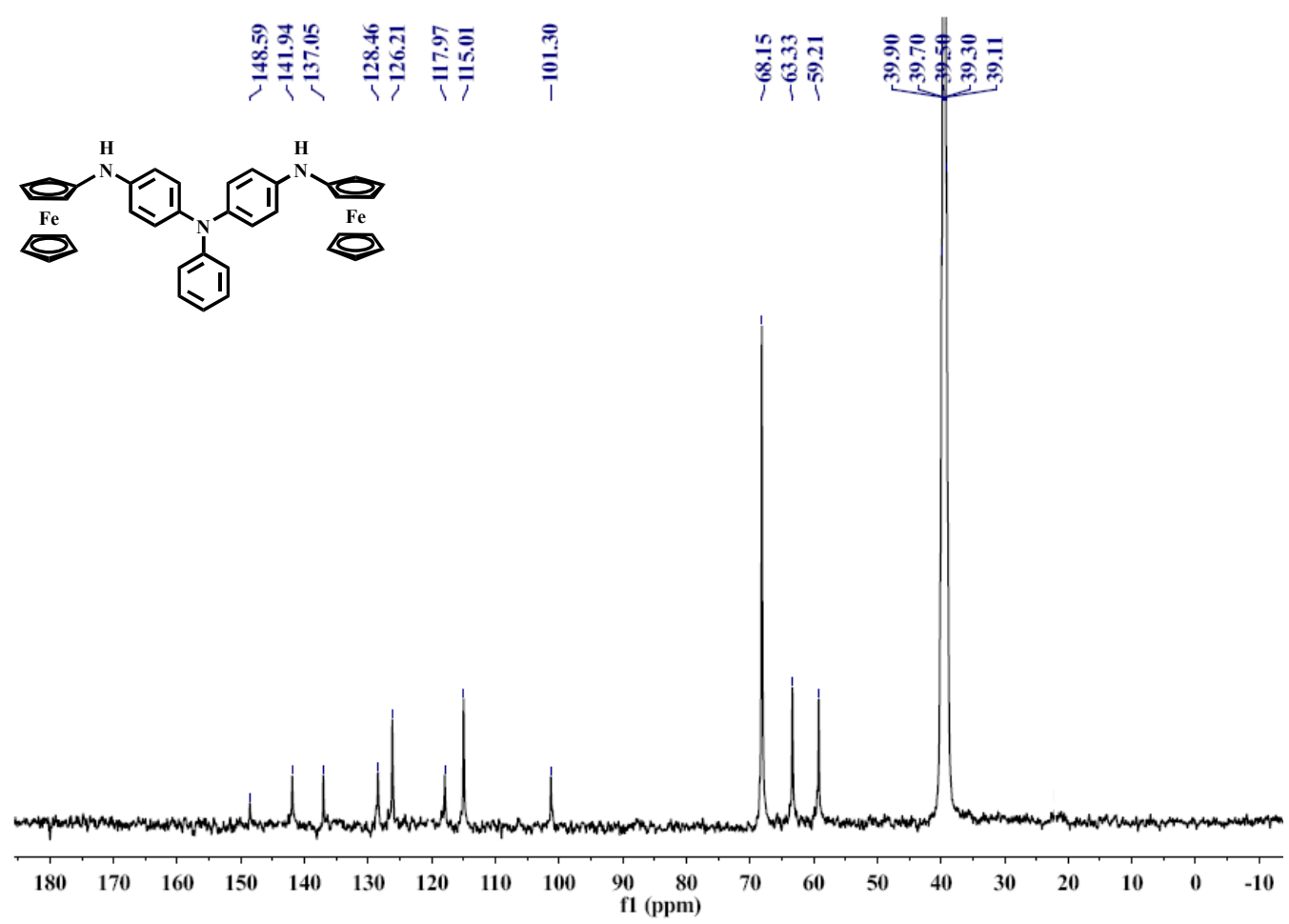

Figure S23. ${ }^{13} \mathrm{C}$ NMR spectrum $\left(100 \mathrm{MHz}\right.$, DMSO-d $\left.\mathrm{d}_{6}\right)$ of $\mathbf{2 f}$. 
Dalton Transactions

Page 52 of 119

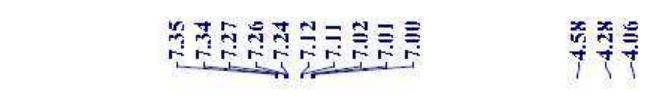
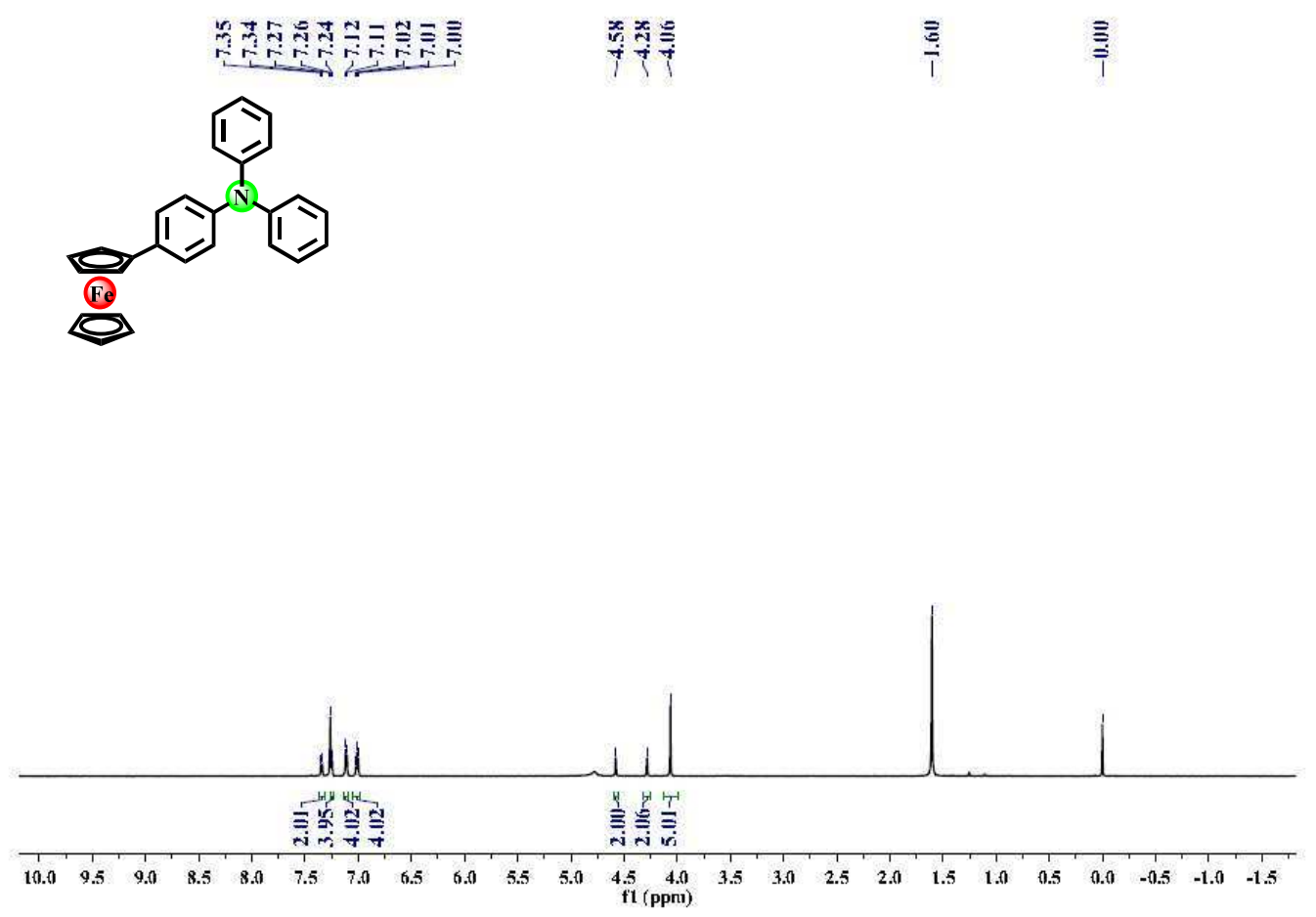

Figure S24. ${ }^{1} \mathrm{H}$ NMR spectrum $\left(400 \mathrm{MHz}, \mathrm{CDCl}_{3}\right)$ of $\mathbf{1 a}$.

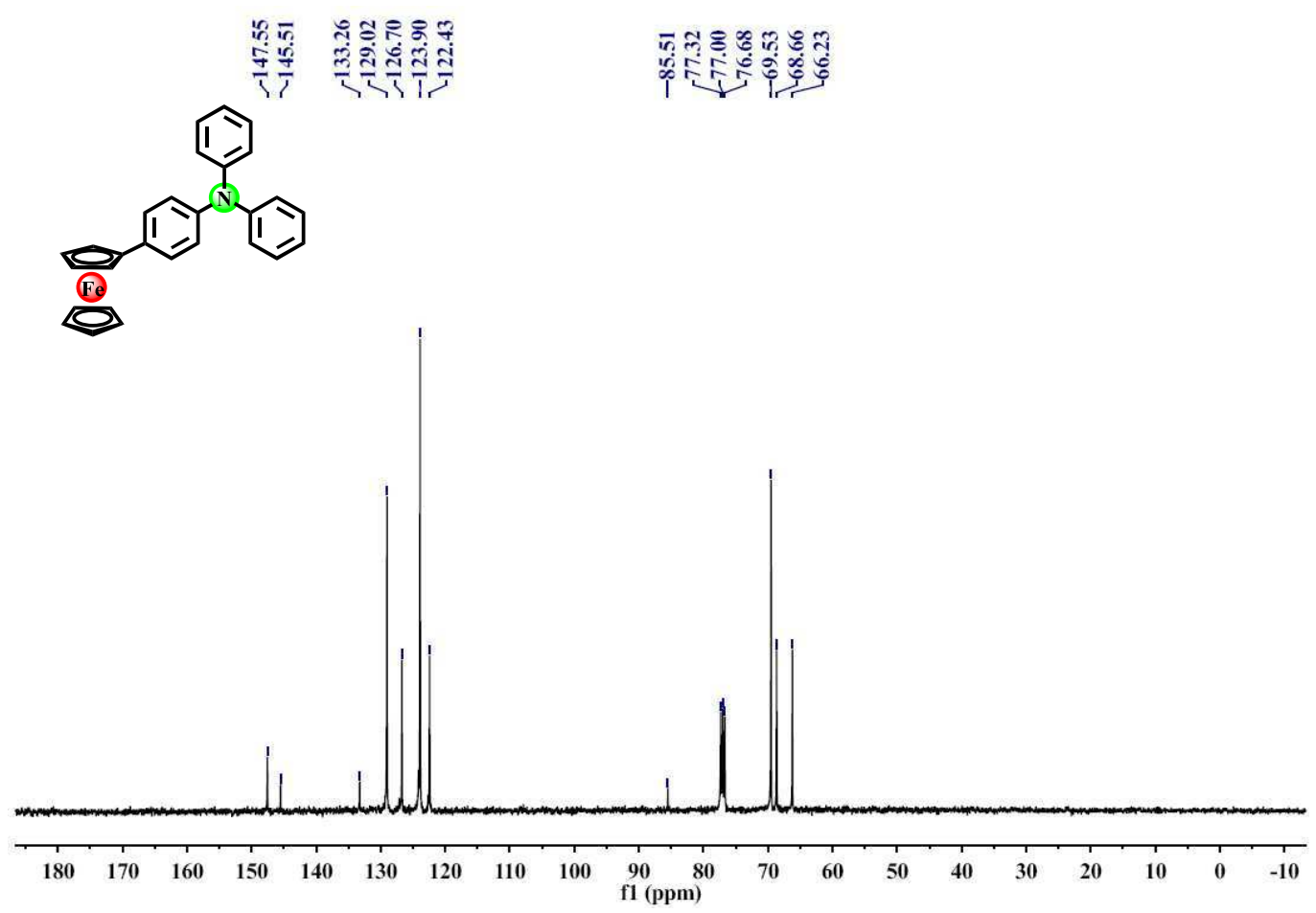

Figure S25. ${ }^{13} \mathrm{C}$ NMR spectrum $\left(100 \mathrm{MHz}, \mathrm{CDCl}_{3}\right)$ of $\mathbf{1 a}$. 


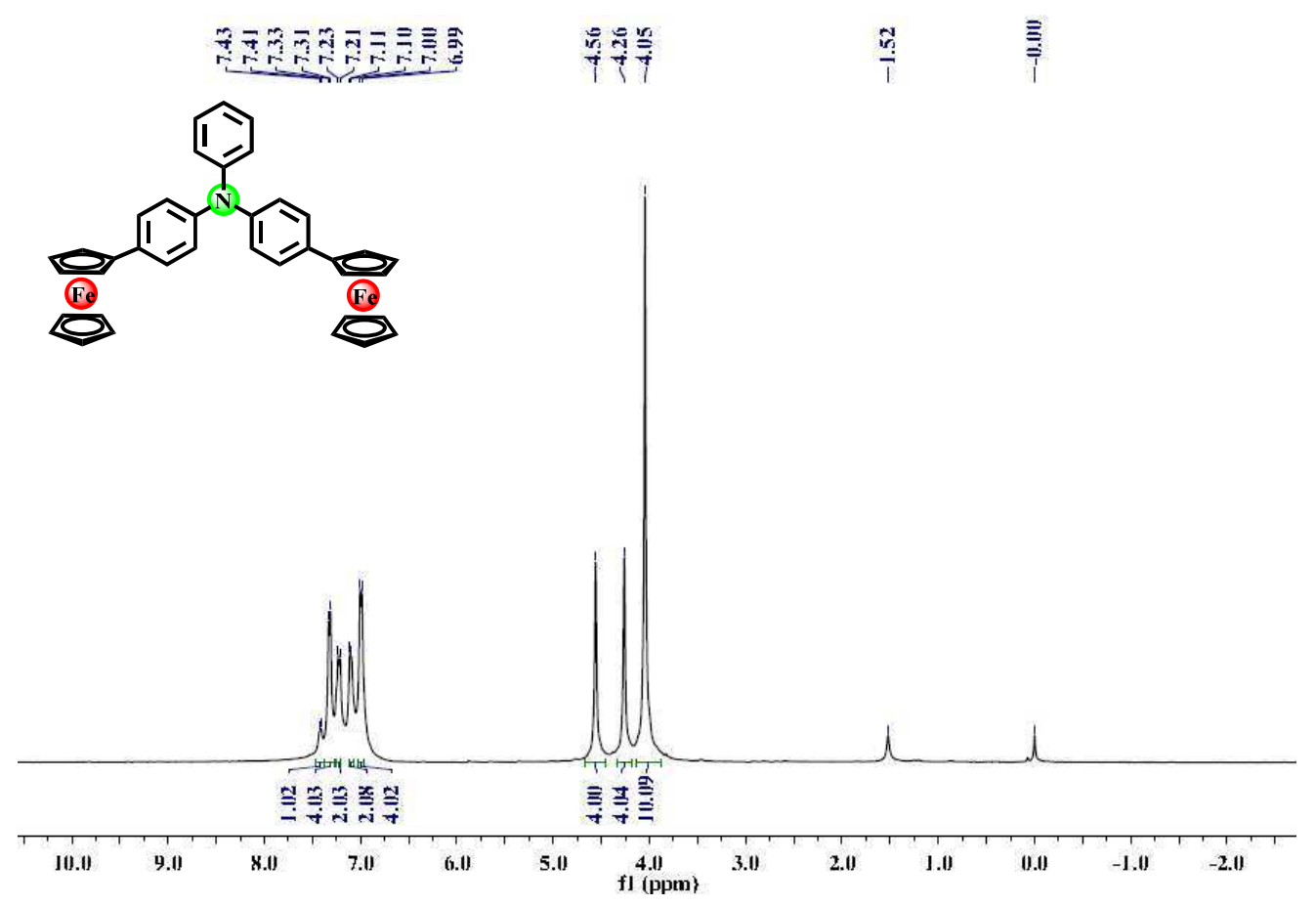

Figure S26. ${ }^{1} \mathrm{H}$ NMR spectrum $\left(400 \mathrm{MHz}, \mathrm{CDCl}_{3}\right)$ of $\mathbf{1 b}$.

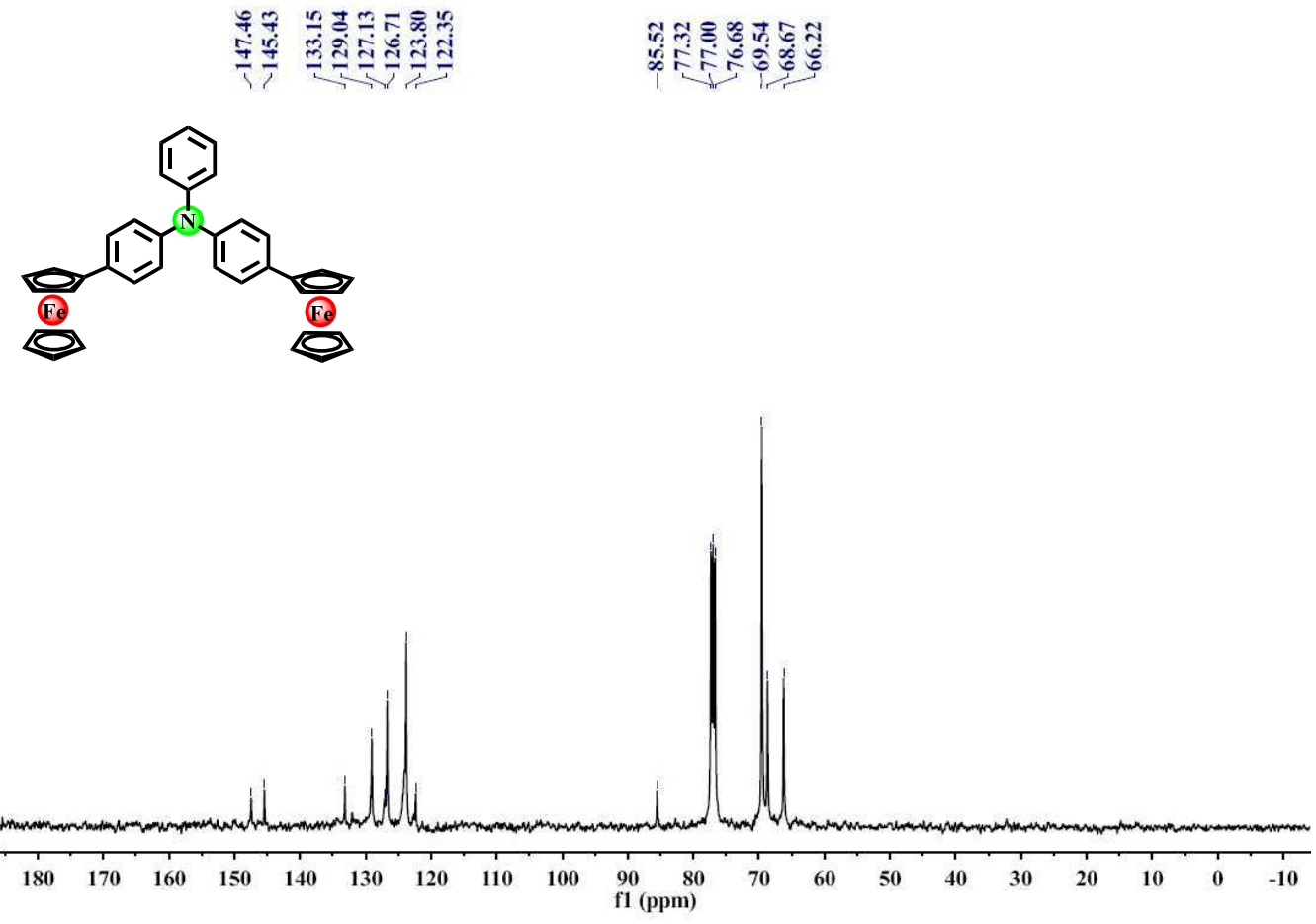

Figure S27. ${ }^{13} \mathrm{C}$ NMR spectrum $\left(100 \mathrm{MHz}, \mathrm{CDCl}_{3}\right)$ of $\mathbf{1 b}$. 

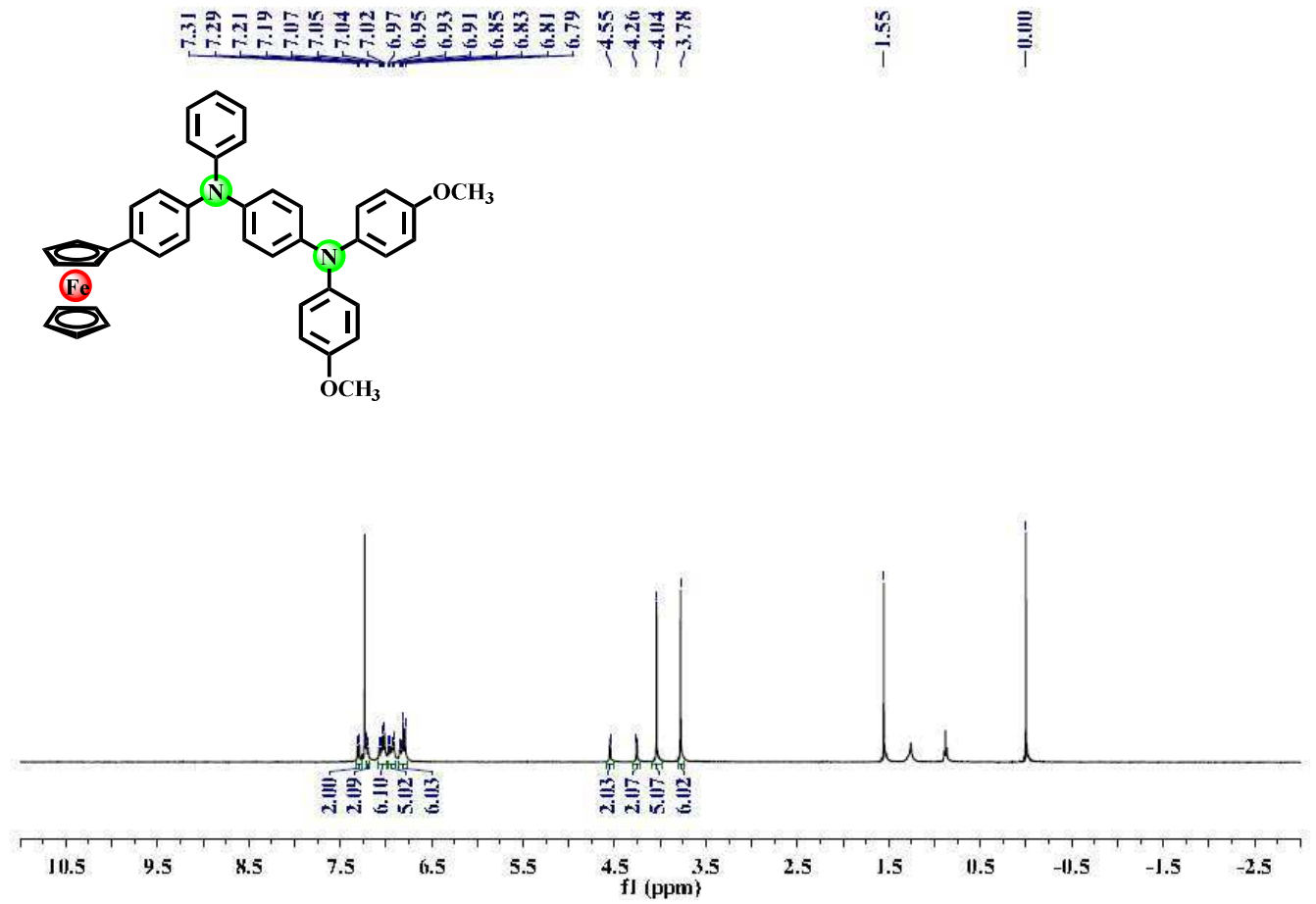

Figure S28. ${ }^{1} \mathrm{H}$ NMR spectrum $\left(400 \mathrm{MHz}, \mathrm{CDCl}_{3}\right)$ of $\mathbf{1 c}$.
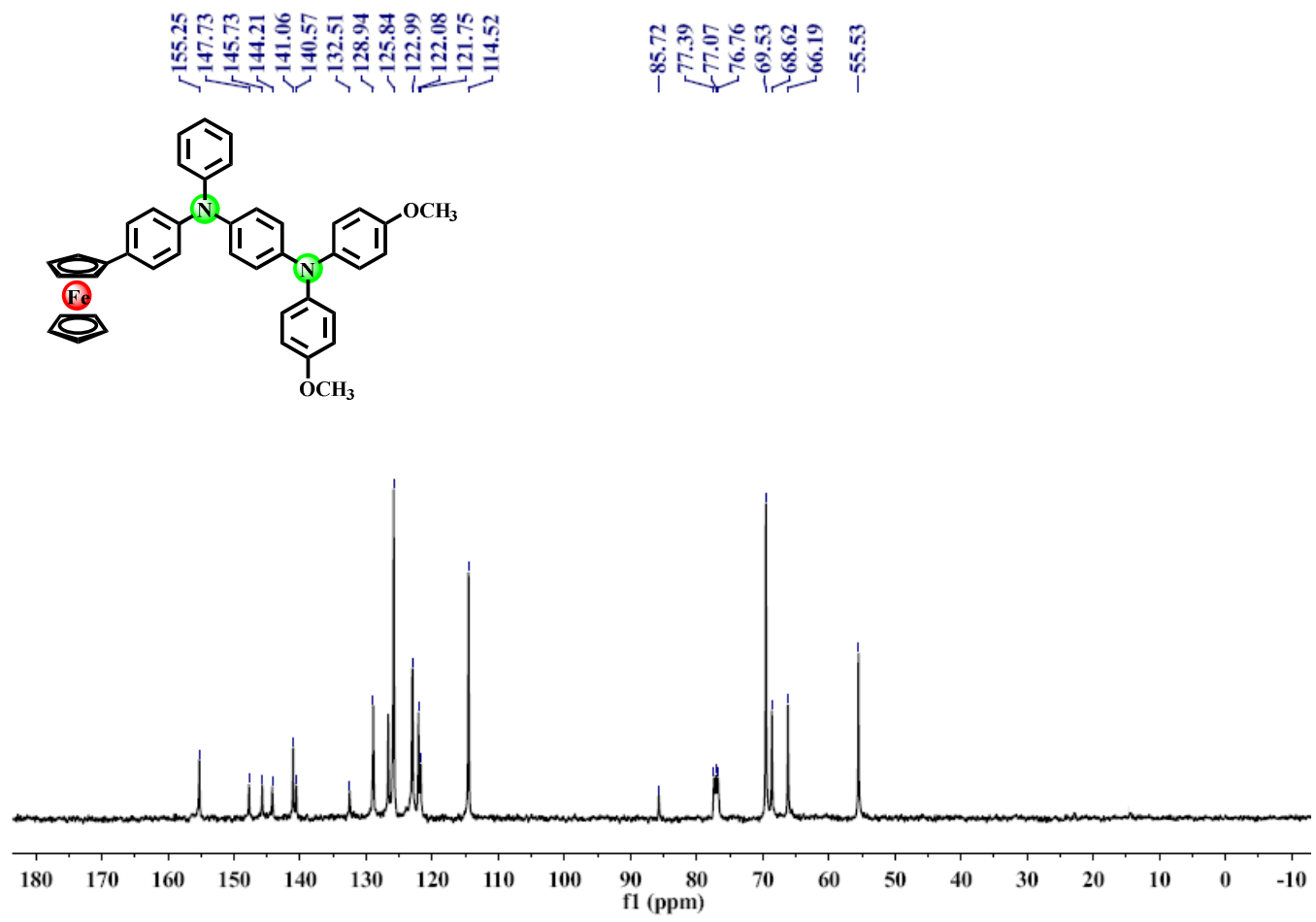

Figure S29. ${ }^{13} \mathrm{C}$ NMR spectrum $\left(100 \mathrm{MHz}, \mathrm{CDCl}_{3}\right)$ of $\mathbf{1 c}$. 
Page 55 of 119

Dalton Transactions

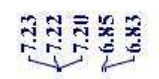

䑶瑟

$\frac{5}{1}$

$\stackrel{\equiv}{\overline{1}}$
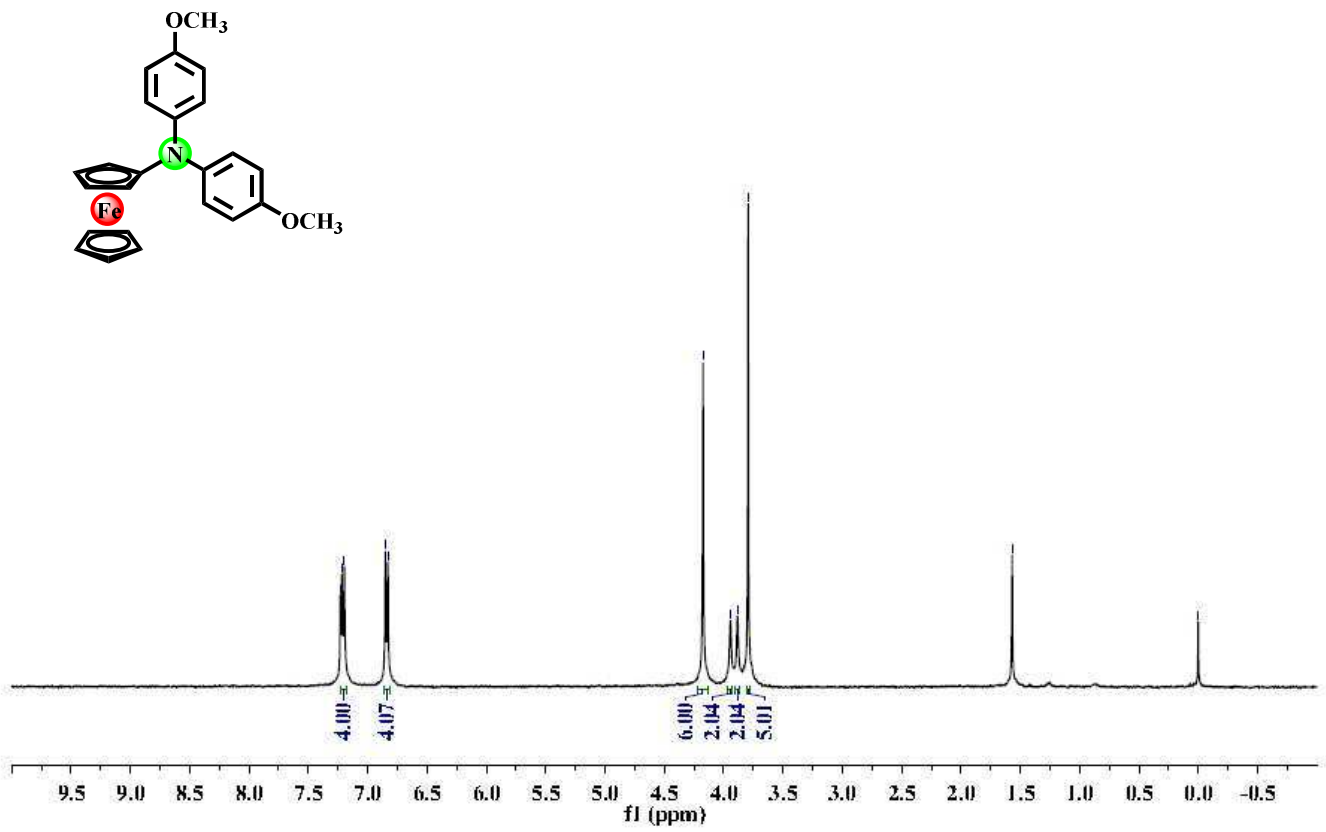

Figure S30. ${ }^{1} \mathrm{H}$ NMR spectrum $\left(400 \mathrm{MHz}, \mathrm{CDCl}_{3}\right)$ of $\mathbf{1 d}$.
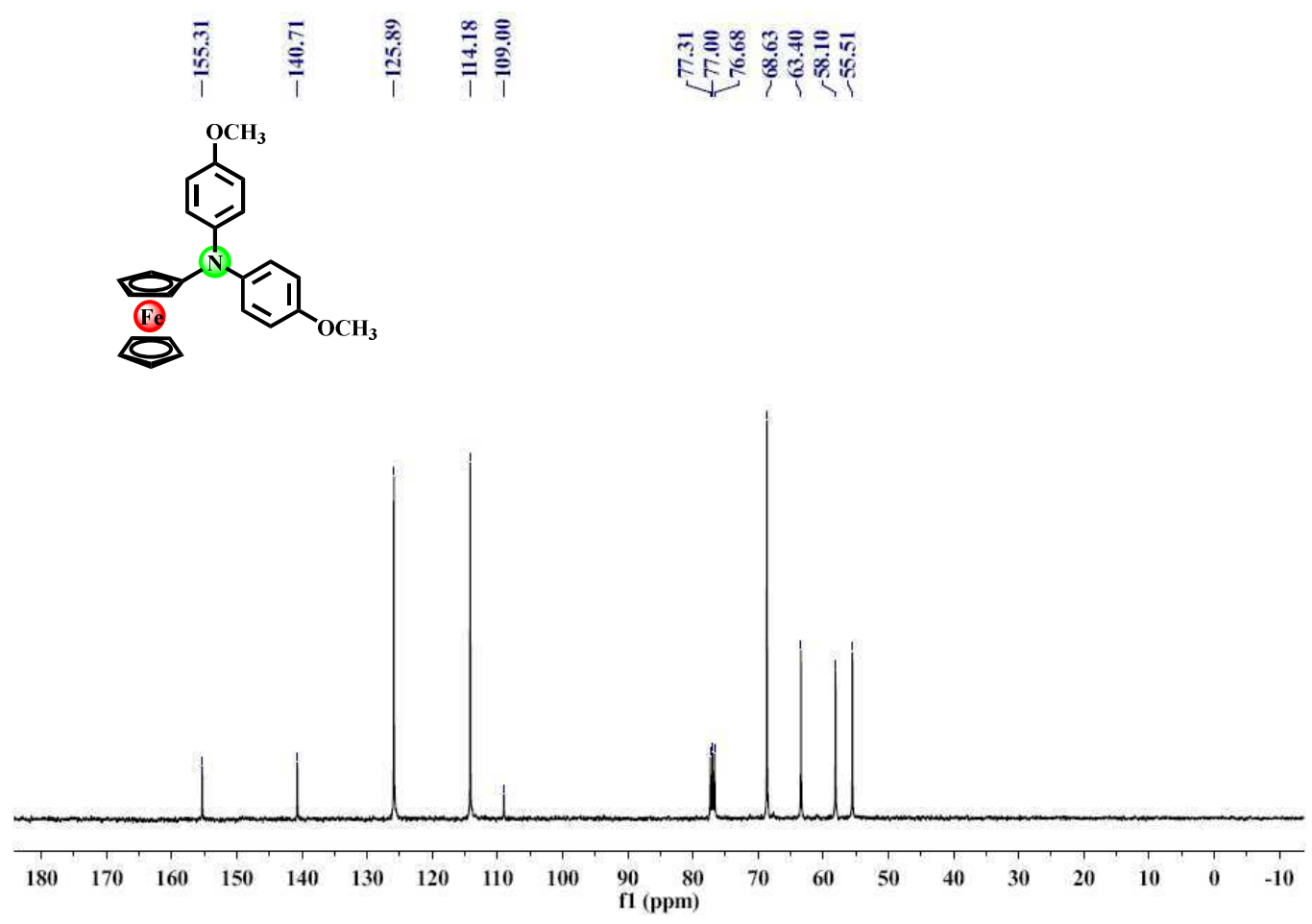

Figure S31. ${ }^{13} \mathrm{C}$ NMR spectrum $\left(100 \mathrm{MHz}, \mathrm{CDCl}_{3}\right)$ of $\mathbf{1 d}$. 


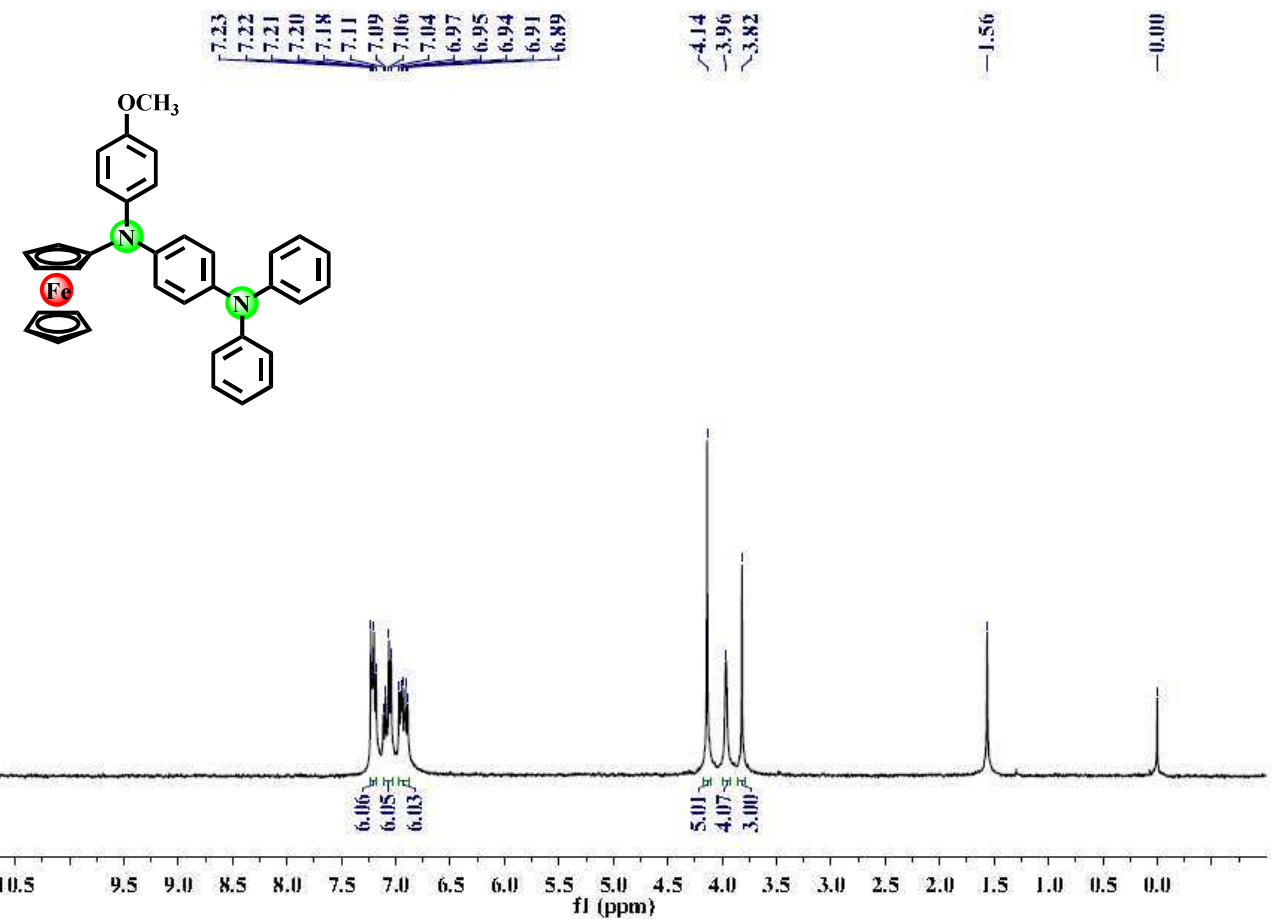

Figure S32. ${ }^{1} \mathrm{H}$ NMR spectrum $\left(400 \mathrm{MHz}, \mathrm{CDCl}_{3}\right)$ of $\mathbf{1 e}$.
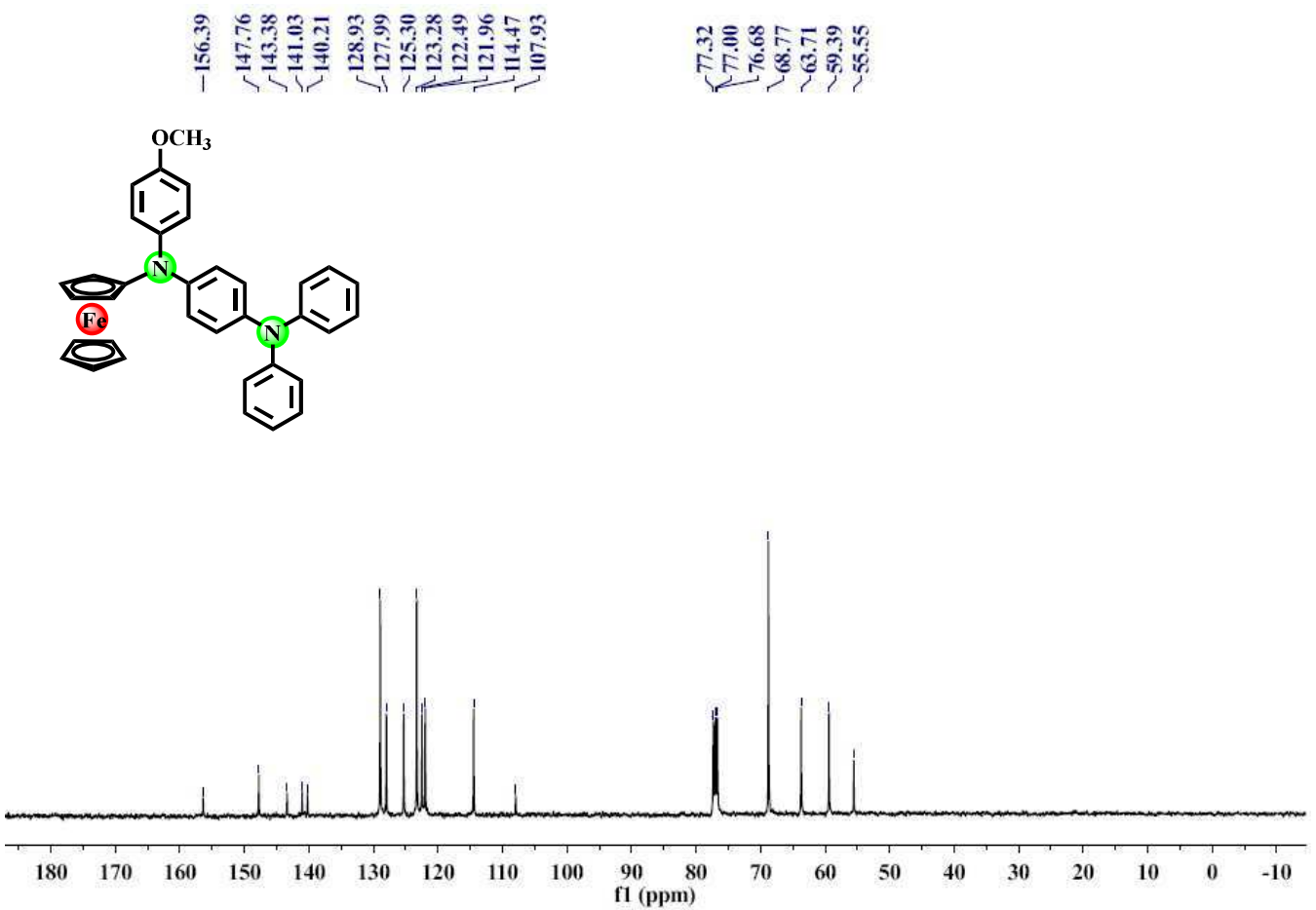

Figure S33. ${ }^{13} \mathrm{C}$ NMR spectrum $\left(100 \mathrm{MHz}, \mathrm{CDCl}_{3}\right)$ of $\mathbf{1 e .}$ 


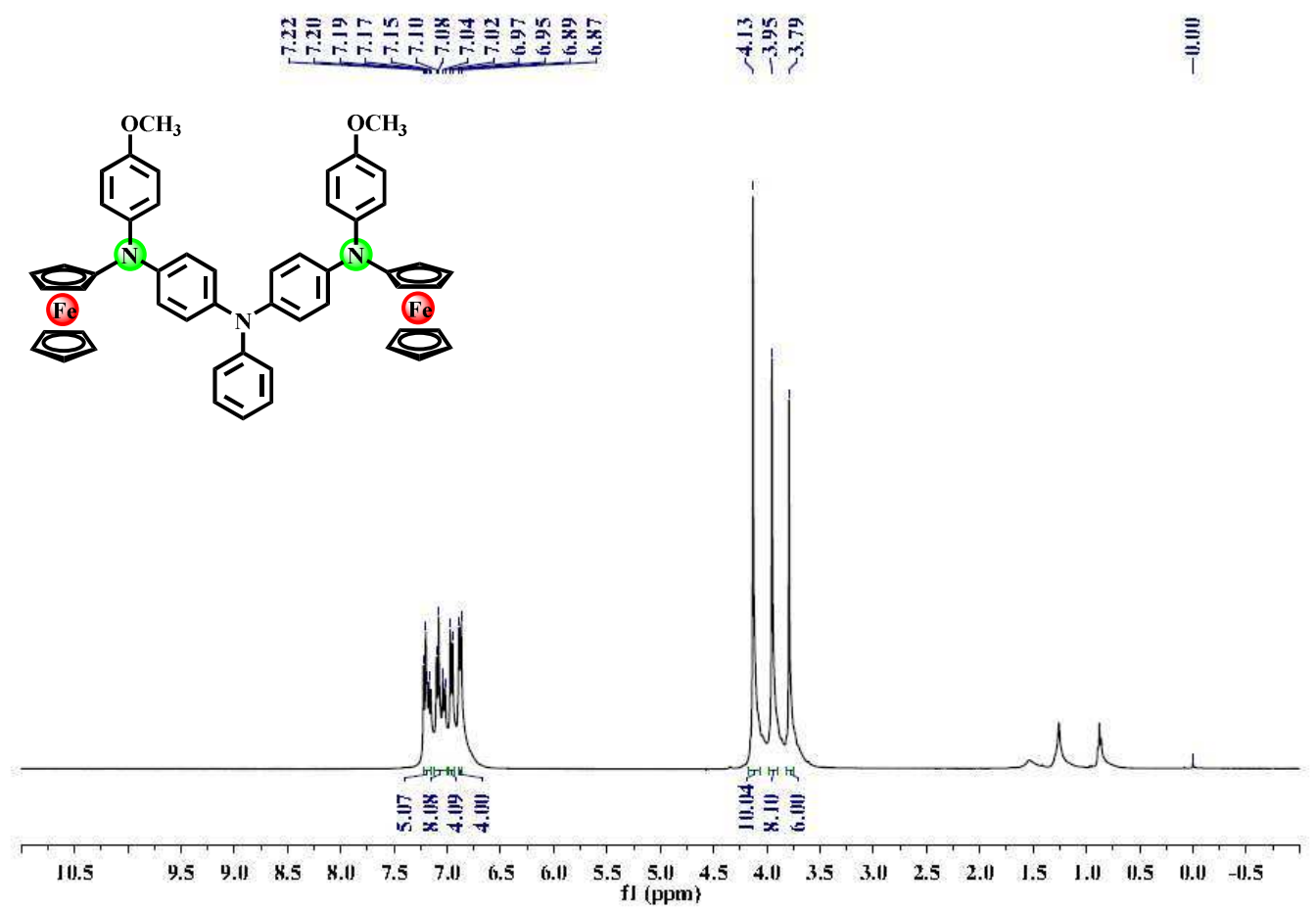

Figure S34. ${ }^{1} \mathrm{H}$ NMR spectrum $\left(400 \mathrm{MHz}, \mathrm{CDCl}_{3}\right)$ of $\mathbf{1 f}$.
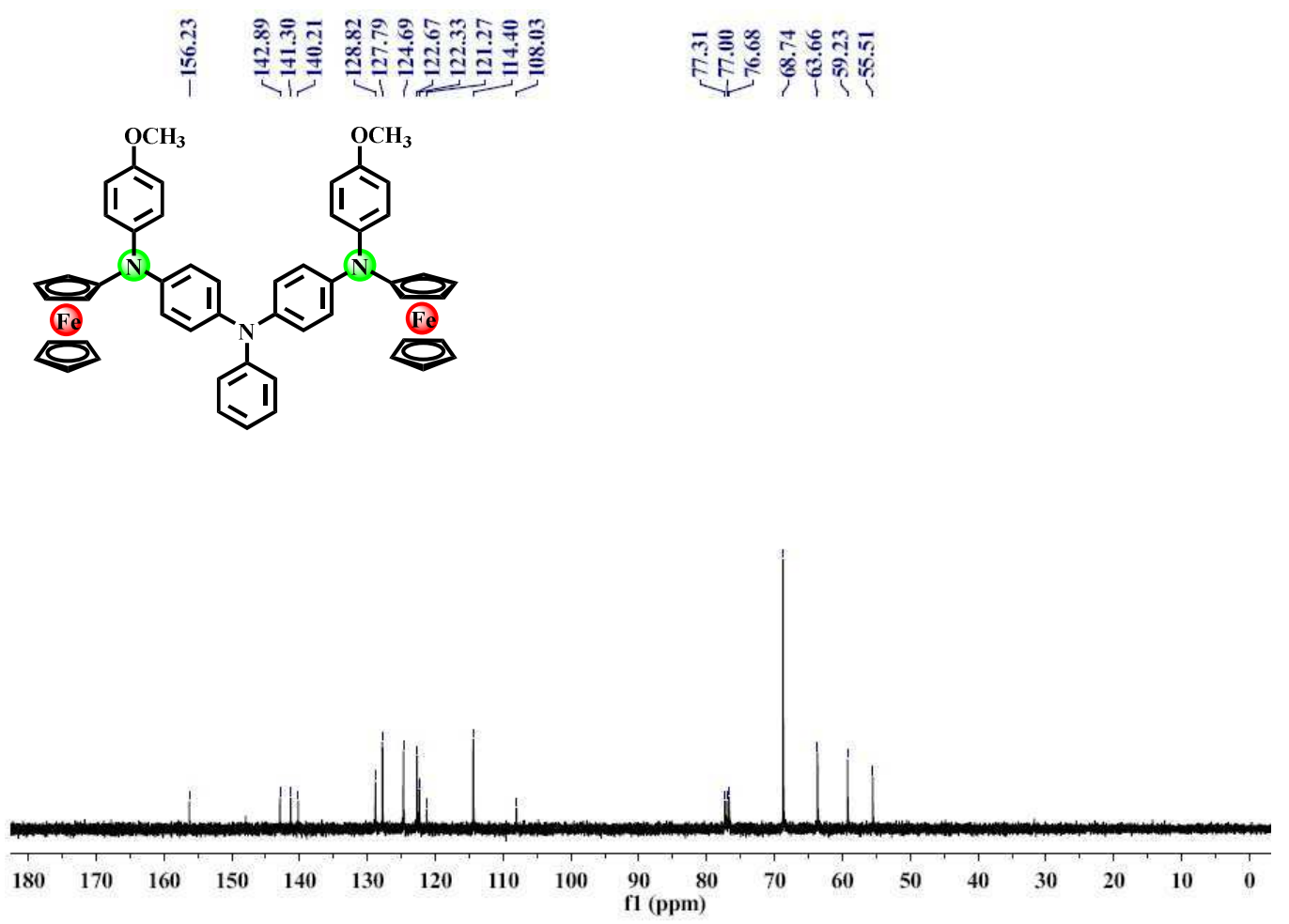

Figure S35. ${ }^{13} \mathrm{C}$ NMR spectrum $\left(100 \mathrm{MHz}, \mathrm{CDCl}_{3}\right)$ of $\mathbf{1 f}$. 


\section{Reviewer 1}

Comments to the Author

This paper from Liu, Hartl and colleagues reports the synthesis and (spectro)electrochemical characterisation of some very nice 'mixed' ferrocene / triarylamine compounds. The experimental work seems to have been very competently carried out, although I have some reservations about the (TD)DFT and interpretation of the low energy bands in the electronic spectra. The paper, in the introduction, conclusion and cover letter, misses an opportunity to convey the wider significance of the study. What can we learn from these studies that will help us to move an area forward? There are some broad aspirational statements in the cover letter, but the Introduction seems to simply be about study these compounds for their own sake. I have no problem with a purely fundamental study (and indeed encourage such work), but I would suggest a clearer expression of 'why' in the introduction and a stronger conclusion to improve the impact of the paper.

Response: The reviewer is gratefully acknowledged for the overall positive judgement and careful reading of the manuscript. The recommendation to extend the background information in the Introduction, and to focus on the reliability of the TD DFT data is gratefully acknowledged. The details on the latter issue follow hereinafter.

My major concern with the paper lies in the interpretation of the UV $\square$ vis $\square$ NIR spectra based on the TD DFT results. The B3LYP functional is really not appropriate for calculating charge transfer energies and although one compound was calculated with CAM $\square$ B3LYP I think there needs to be a 'health check' on the assignments. In the absence of the TD DFT I think it is fair to suggest that the low energy bands in compounds like [1a] $]^{+}$with extinction coefficients of $>5000 \mathrm{M}^{\square 1} \mathrm{~cm}$ would be assigned to a TPA $\square$ to $\square \mathrm{Fc}^{+}$charge transfer (beta $\square$ HOSO $\square$ to $\square$ beta $\square$ LUSO) and the higher energy visible bands would (likely) be the alpha analogues. I find it very unusual to consider the assignments given in Table 4. Now, of course there is always a case to be made that chemical intuition is not correct and that is of course how we make advances, but if the TD DFT (from a functional that is known to be unsuitable for these sorts of calculations) tells me something at odds with expectation, I would like to see that result robustly tested. It would seem that a quick SEC experiment with phenylferrocene would be enough to either prove the unusual $\mathrm{Fe} \square \mathrm{Fc}^{+}$assignment by demonstrating the ca. $6000 \mathrm{M}^{\square} \mathrm{cm}^{\square 1}$ band near $7000 \mathrm{~cm}^{\square 1}$, or support assignment as TPA $\square$ to $\square \mathrm{Fc}^{+}$. I strongly advise this check to be made. If this proves the amine $\square$ to $\square$ ferrocenium charge transfer character, then the TD DFT will need to reconsidered, and perhaps re $\square$ performed with a more suitable functional consistently.

Response: We cordially thank the reviewer for the above valuable suggestions. We have indeed used phenylferrocene ( $\mathrm{Ph}-\mathrm{Fc}$ ) as the suited reference compound and oxidized it smoothly to $[\mathrm{Ph}-\mathrm{Fc}]^{+}$with $\operatorname{AgPF}_{6}\left(E_{1 / 2}=+0.04 \mathrm{~V}\right.$ vs $\left.\mathrm{Fc} / \mathrm{Fc}^{+}\right)$. The electronic absorption spectra of the ferrocenium product (Figure S14 below) do not show any obvious new absorption in the NIR 
region, which may indicate the amine $\square$ to $\square$ ferrocenium charge transfer character of the lowest-energy electronic transition for all the monocationic states we have described, as was suspected by the reviewer. However, we still believe that our original assignment is correct. For, we have also simulated the electronic absorption of $[\mathrm{Ph}-\mathrm{Fc}]^{+}$by using the B3LYP and CAM-B3LYP methods and the results are well consistent with the experimental data (Figures S15 and S16). Especially B3LYP has reproduced well energies the relatively weak absorption in the 600-800 nm region, which shows a limited charge-transfer ( $\mathrm{Ph}-$ to- $\mathrm{Fc}^{+}$) character. Notably, CAM-B3LYP reveals the peculiar Fe-to- $\mathrm{Fc}^{+}$lowest-energy transition also for the reference. It also needs to be noted that the NIR absorption of the studied monocations is also far from being strong, with the molar absorptivity between 2000-3000 $\mathrm{M}^{-1} \mathrm{~cm}^{-1}$ (see Table 3), i.e., not above 5000 $\mathrm{M}^{-1} \mathrm{~cm}^{-1}$ (?) as argued above by the reviewer. We therefore consider these two methods to be suitable also for our monocationic radical systems. The simulated low-energy absorption bands are basically consistent with the SEC results. Even though the charge transfer energies obtained may not be completely coincident, in our opinion the predicted nature of the transitions should be reasonable. In addition, especially CAM-B3LYP has generally been accepted to perform well for charge-transfer excitation (T. Yanai et al., Chemical Physics Letters 393 (2004) 51-57). We have employed this hybrid functional successfully for $[\mathbf{1 c}]^{+}$, with similar results as obtained with B3LYP for the rest of the monocationic series.

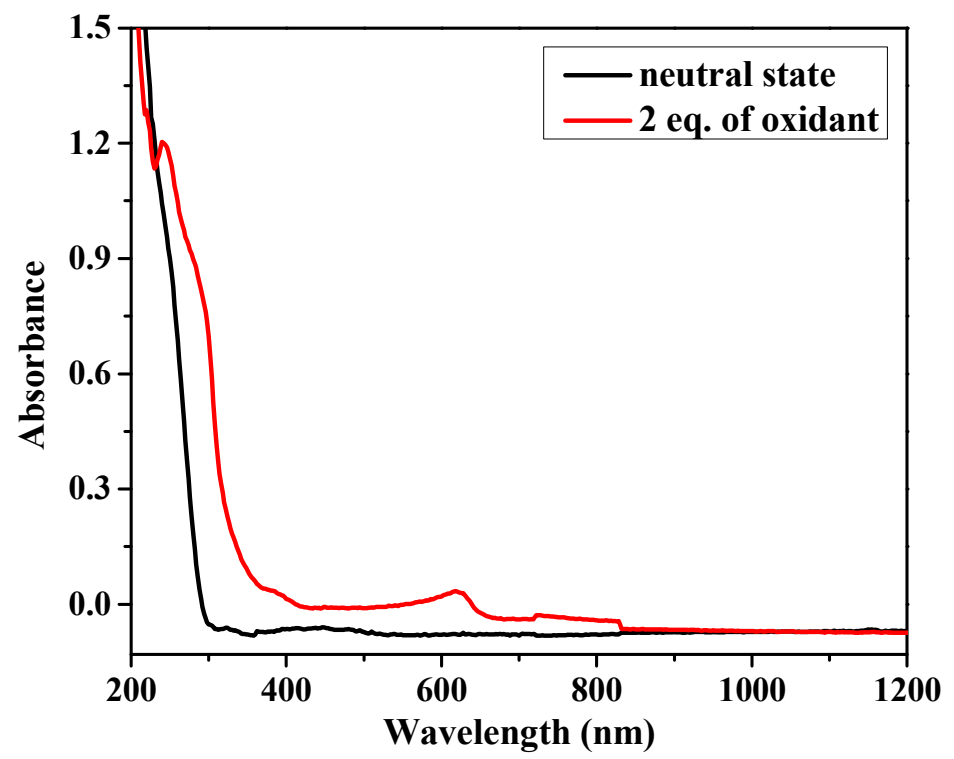

Figure S14. Electronic absorption spectra of $10^{-2} \mathrm{M}$ Ph-Fc (black line) and $[\mathrm{Ph}-\mathrm{Fc}]^{+}$(red line) obtained by chemical oxidation with $\mathrm{AgPF}_{6}$ in $\mathrm{CH}_{2} \mathrm{Cl}_{2}$ at $298 \mathrm{~K}$. The simulated spectra of $[\mathrm{Ph}-\mathrm{Fc}]^{+}$ and corresponding electronic transitions obtained with TD-DFT methods are depicted in Figures S15-S17. 


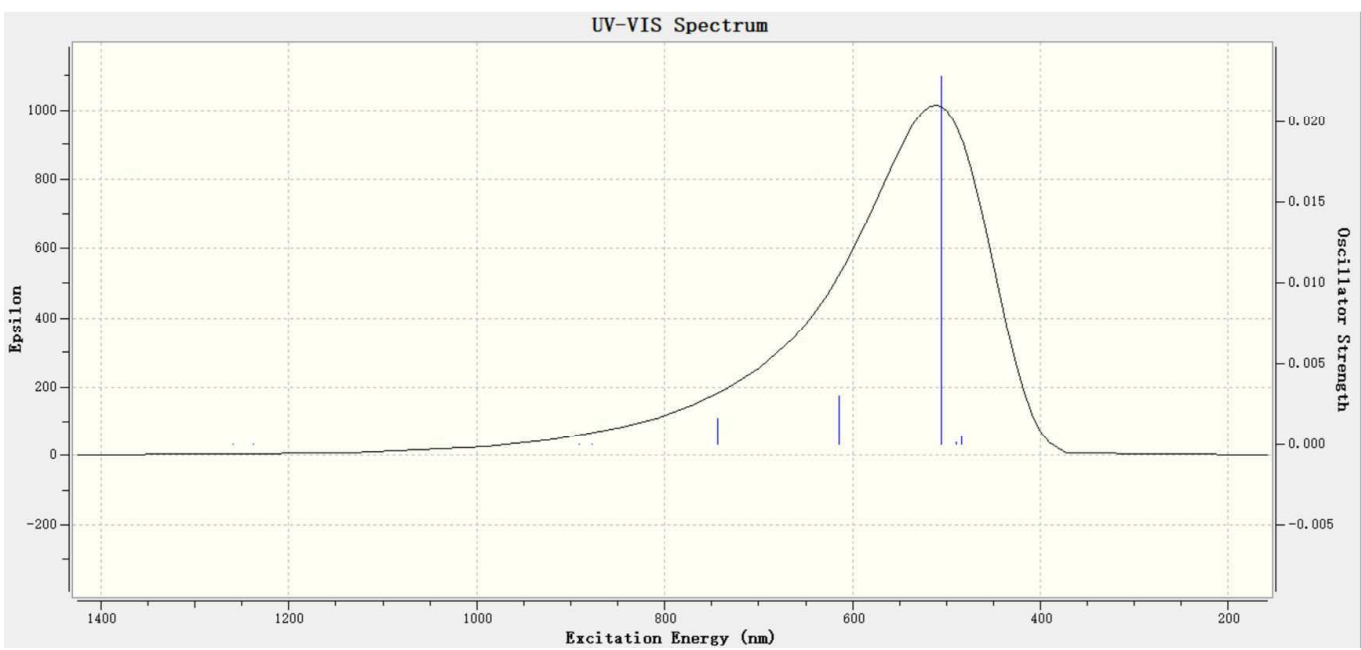

Figure S15. Simulated electronic absorption of $[\mathrm{Ph}-\mathrm{Fc}]^{+}$. B3LYP/6-31G*/CPCM $/ \mathrm{CH}_{2} \mathrm{Cl}_{2}$.

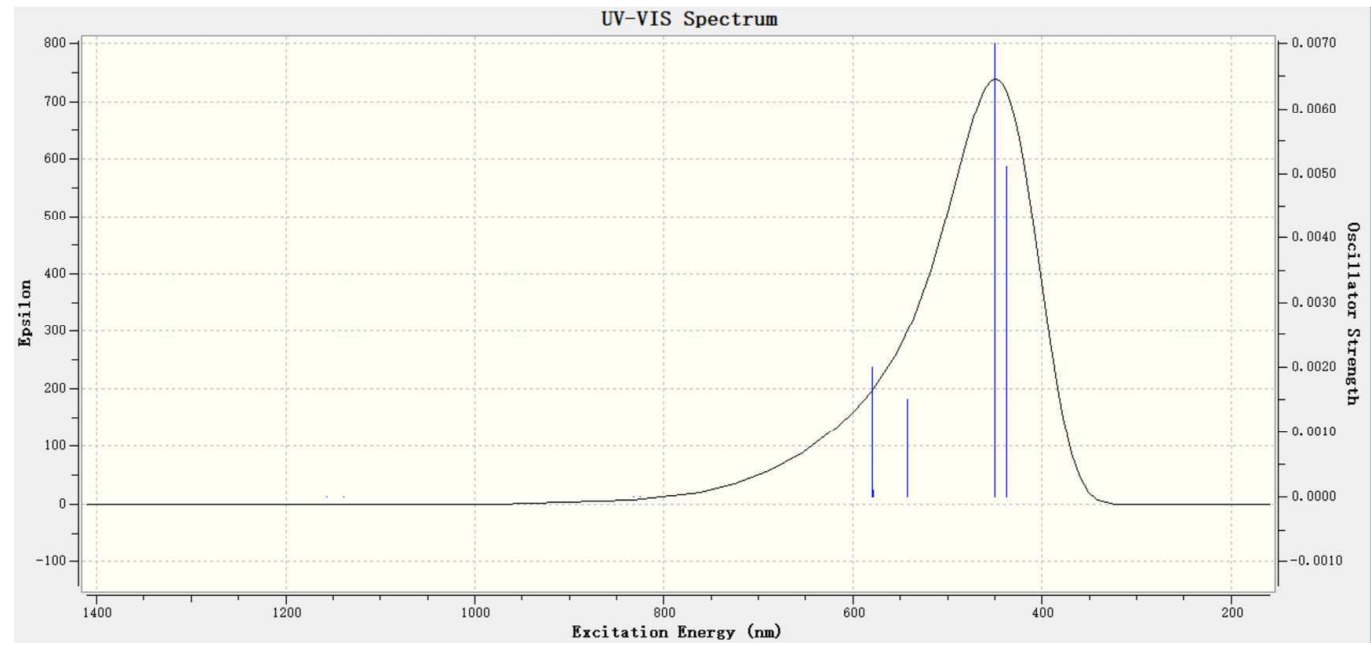

Figure S16. Simulated electronic absorption of $[\mathrm{Ph}-\mathrm{Fc}]^{+}$; CAM-B3LYP/6-31G*/CPCM / $\mathrm{CH}_{2} \mathrm{Cl}_{2}$. 


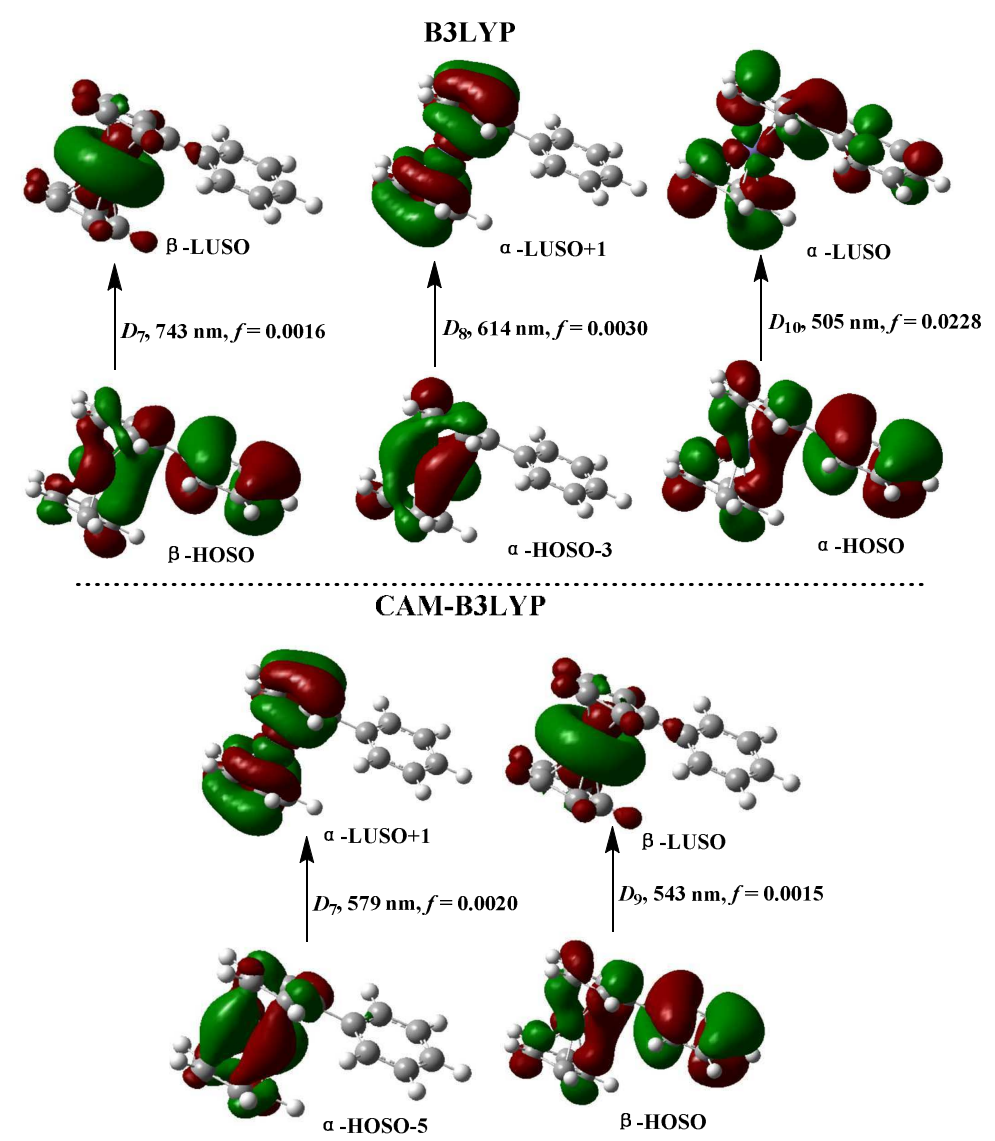

Figure S17. Spin orbitals involved in the plausible calculated visible electronic excitations of $[\mathrm{Ph}-\mathrm{Fc}]^{+}$(see Figures S15 and S16). A better agreement with the experimental visible absorption of the cationic complex has been reached with the B3LYP method.

Other small points:

- Re $\square$ write the Abstract so it can be appreciated without knowing the identity of compounds by number but not formula.

Response: We thank the reviewer for this suggestion! We have rewritten the Abstract and identified all the complexes accordingly so that the inspection of the main text is not needed anymore to obtain quick orientation. The changes have been highlighted by yellow boxes.

- Give esd's in the discussion of the crystallographically determined molecular structure.

Response: Our apologies for having omitted esd's in the original manuscript. This has been rectified in the revised manuscript version.

- The atoms are labelled in Figure $1 \square$ the color commentary is not necessary.

Response: We have deleted the color commentary in Figure 1 accordingly.

- $\quad \operatorname{pg} 6 \square$ the authors should be well aware of the limitations of using electrochemical waves to assign Robin $\square$ Day class. Please make these comments with a little more commentary 
about the underlying assumptions.

Response: For the sake of clarity we have dropped the Robin-Day classification from the original sentence that reads now as "This localized behavior closely resembles the initial two-electron oxidation reported for a TPA-bridged diethynyl diiron complex.”. We are of course aware of the limitations of cyclic voltammetry and the value of $\mathrm{K}_{\mathrm{c}}$ value based thereupon (also affected by the electron transfer kinetics and the stability of the redox couple components) for discussing the degree of interaction between the bridged redox centres. Here, however, the case is clear (Class I) as also evidenced by the calculated spin density for $[\mathbf{1 b}]^{+}$and the very similar electronic absorption of $[\mathbf{1 b}]^{+}$and $[\mathbf{1 b}]^{2+}$ (Figure S3), and is not worth of a deeper discussion. In Conclusions we have modified the summarizing sentence: The symmetric TPA-bridged diferrocenyl, 1b, and bis(phenylaminoferrocenyl), 1f, complexes behave as localized redox systems with minimal interaction between the iron centres, undergoing facile redox disproportionation in the one-electron-oxidized state.

- The data in Table 4 concerns me $\square$ especially given the rather poor agreement of extinction coefficients and oscillator strengths and the peculiar assignment of the low energy bands (as described above). Please use a reference compound or two to verify the assignment and give greater confidence in the calculations.

Response: This critical point raised by the reviewer has already been dealt with in some detail above. Strictly speaking, theoretical calculation is an auxiliary means to better clarify experimental results and we believe our basic purpose has been achieved. Actually, the B3LYP-calculated oscillator strength of the lowest electronic transition in the most straightforward case of $[\mathbf{1 a}]^{+}$is not that low (0.07) compared to the visible electronic absorption. $[\mathbf{1} \mathbf{c}]^{+}$has been calculated with CAM-B3LYP (showing similar results); we wish to underline that with this hybrid functional we have achieved recently very satisfactory results even in cases that remained unresolved for years (e.g., triosmium carbonyl diamine clusters with a variable degree of (de)localization of frontier orbitals involved in optical electron transfer). We are grateful to the reviewer for his well-formulated concerns but our data, including the phenylferrocene reference, do not disqualify the hybrid functionals used. We have to conclude that the amine-to-ferrocenium $\mathrm{CT}$ in the monocationic species is encountered in the visible region and the lowest electronic transition most likely features the peculiar intra-ferrocenium character.

Actually, we have recently reported a similar type of electronic transition in the NIR region, having a partial interconfigurational (IC) character typically observed for similar dominant Fe(III) systems, for the monocation $\left[\left\{\mathrm{Cp}^{*} \mathrm{Fe}^{\mathrm{II} / \mathrm{III}}(\mathrm{dppe})\right\}_{2}\left\{\mu(-\mathrm{C} \equiv \mathrm{C})_{2} \mathrm{TPA}\right\}\right]^{+}$: Multistep oxidation od diethynyl oligophenylamine-bridged diruthenium and diiron complexes. J. Zhang, S.-Z. Guo, Y.-B. Dong, L. Rao, J. Yin, G.-A. Yu, F. Hartl, S. H. Liu, Inorg. Chem. 2017, 56, 1001-1015. The donor TPA bridge core also did not contribute by a charge transfer in that redox-localized case. 


\section{Reviewer 2}

Comments to the Author

This is a nice manuscript that deals with the sythesis of various molecules containing ferrocene and amine types of donors. The authors have carried out a thorough investigation of their complexes through electrochemistry and UV $\square$ vis $\square$ NIR spectroelectrochemistry, and DFT calculations. The results presented here will be benefial to the community working on ferrocene containing compounds and in general redox active complexes. I do not have any adverse criticism and can recommend the publication of this work.

Response: The positive evaluation is warmly appreciated.

At this point, we do hope to have addressed all the concerns raised by Reviewer 1 in a satisfactory manner and look forward to receiving the Editorial decision.

On behalf of all the co-authors,

With kind regards,

Dr Frantisek Hartl (Reading, $4^{\text {th }}$ April 2018) 


\section{Anodic Electrochemistry of Mono- and Dinuclear}

\section{Aminophenylferrocene and Diphenylaminoferrocene}

\section{Complexes}

Ming-Xing Zhang, ${ }^{\dagger, \S}$ Jing Zhang, ${ }^{\dagger, \pi}$ Jun Yin, ${ }^{\dagger}$ František Hartl, ${ }^{*}{ }^{\star}$ Sheng Hua Liu* ${ }^{* \dagger}$

${ }^{\dagger}$ Key Laboratory of Pesticide and Chemical Biology, Ministry of Education, College of Chemistry, Central China Normal University, Wuhan 430079, P.R. China

${ }^{\Uparrow}$ College of Chemistry, The Hong Kong University of Science and Technology, Clear Water Bay, Kowloon, Hong Kong

${ }^{\ddagger}$ Department of Chemistry, University of Reading, Whiteknights, Reading RG6 6AD, $U K$

${ }^{\S}$ These authors have contributed equally to this work.

\section{Abstract}

Two related three-membered series of nonlinear aminophenylferrocene and diphenylaminoferrocene complexes were prepared and characterized by ${ }^{1} \mathrm{H}$ and ${ }^{13} \mathrm{C}$ NMR spectroscopy. The first series consists of 4-(diphenylamino)phenylferrocene (TPA-Fc, 1a), its dimethoxy-substituted tetraphenylphenylenediamine derivative (M2TPPD-Fc, 1c), and the triphenylamine-bridged bis(ferrocenyl) complex (Fc-TPA-Fc, 1b). The second series involves bis(4-methoxyphenyl)aminoferrocene (M2DPA-Fc, 1d), 4-methoxyphenylaminoferrocene (MPA-Fc) with $N$-phenyl-appended terminal TPA (1e), and the corresponding bis(MPA-Fc) complex with bridging TPA (1f). The structure of complex 1d was further confirmed by single crystal X-ray diffraction. Combined investigations, based on anodic voltammetry, UV-vis-NIR spectroelectrochemistry and density functional theory (DFT) calculations, were conducted to illustrate the influence of the integration of multiple redox-active components on the sequential oxidation of these complexes. The first anodic steps in 
1a-1f are localized preferentially on the ferrocenyl units, followed by oxidation of the TPA or TPPD moieties (absent in 1d). Irreversible oxidation of the ferrocene-appended strong donor DPA/MPA units in 1d-1f terminates the anodic series. The one-electron oxidation of the triphenylamine-bridged diferrocenyl (1b) and bis(phenylaminoferrocenyl) (1f) complexes triggers their facile redox disproportionation to dicationic bis(ferrocenium) products.

Keywords: Arylamine bridge; Ferrocene; Oxidation; Spectroelectrochemistry; DFT Calculations

\section{Introduction}

Ferrocene (Fc) and triphenylamine (TPA) have been considered as ideal redox centers to study the intramolecular electron transfer processes in mixed-valence (MV) systems due to the favorable reversibility of their anodic reactions and stability of the oxidized forms. ${ }^{1-4}$ In the realm of MV species, numerous studies focused in the past decades on $\pi$-conjugated bridging ligands, such as heterocycles, oligoene, oligoyne, phenylene, phenylene-yne, thienyl ethynyl, and oligoacene units. ${ }^{5,6}$ However, studies of the MV behavior with compounds featuring the TPA unit as the non-innocent bridging ligand, and ferrocene as the terminal redox-active center, are relatively limited, ${ }^{4 a, 7}$ let alone the scarcer diphenylaminoferrocene (DPA-Fc) systems, where the donor nitrogen is directly bound to one of the ferrocene cyclopentadienyl rings, both constituting "electron-rich" units. ${ }^{8}$ According to our survey, the DPA-Fc systems appending diphenylamino groups to the ferrocene core are excellent $p$-type materials with good electrochemical stability and high hole mobility. ${ }^{89}$ These excellent properties are most likely due to the incorporation of the DPA groups that enhance intermolecular interactions and thus increase the hole transport properties and stability of the system. Pertinent reports on the DPA-Fc complexes however mainly focus on the exploration of synthetic methods to prepare some simple systems, ${ }^{8,9}$ and detailed studies on their electronic properties, or involvement of more complex species 
featuring multiple redox-active components, are sporadic. From this perspective, an interesting research aspect is a comparative exploration of a series of similar phenylamino-ferrocene systems to clarify their electron-transfer nature and further facilitate their applications. Based on this point, we have been interested in exploring a/ the electronic properties of the linked mono- and dinuclear TPA-ferrocene systems (1a, 1b), b/ the redox-asymmetry of dimethoxy-substituted tetraphenylphenylenediamino-ferrocene (M2TPPD-Fc, 1c), and c/ the methoxy-substituted DPA-Fc derivatives (1d-1f) with TPA in the terminal (1e) and bridging (1f) positions, see Chart 1. The synthetic routes toward 1a-1f featuring the integrated multiple redox-active components are based on a range of Pd-catalyzed coupling reactions (see Scheme 1). We have aimed to elucidate how the redox, spectroscopic, and electronic properties of the two investigated ferrocenyl series are affected by the variation of the ancillary redox-active oligoamino groups. The data sets evaluated in the discussion have been obtained by using controlled-potential voltammetry and UV-vis-NIR spectroelectrochemistry combined with density functional theory calculations.

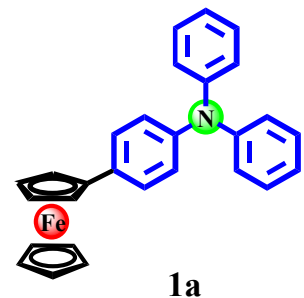

$1 \mathbf{a}$

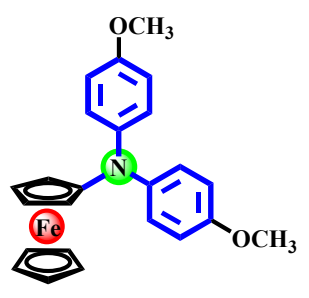

1d

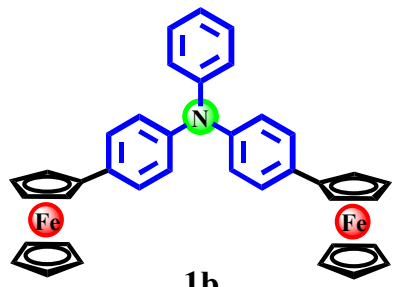

1b

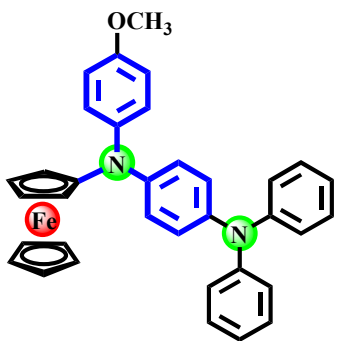

1e
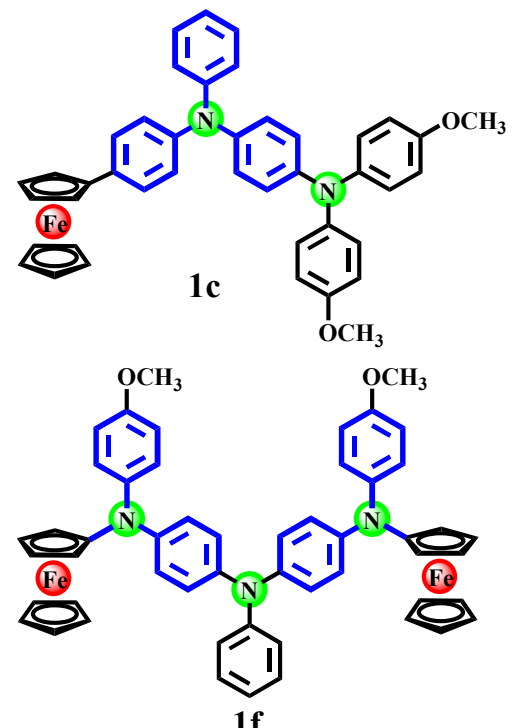

Chart 1. Studied 4-(diphenylamino)phenyl-ferrocene series with TPA (1a, 1b) and M2TPPD (1c), and diphenylaminoferrocene (DPA-Fc) derivatives (1d-1f). 


\section{Results and Discussion}

\section{Syntheses and Characterization}

The synthetic routes to complexes $\mathbf{1 a}-\mathbf{1 f}$ are outlined in Scheme 1. The precursors $2 \mathbf{c}, \mathbf{2 e}$ and $\mathbf{2 f}$ were obtained in moderate yields ranging from $40 \%$ to $70 \%$, by having exploited Pd-catalyzed Buchwald-Hartwig coupling reactions of 4-bromophenylaniline (2a) and 4-bromo- $N$-(4-bromophenyl)- $N$-phenylaniline (2b) with bis(4-methoxyphenyl)amine, and aminoferrocene (3d). Subsequently, bromo-substituted arylamine precursors $\mathbf{2 a - 2 c}$ were reacted with ferrocenylboronic acid by the Pd-catalyzed Suzuki-Miyaura coupling to obtain the corresponding target complexes, 1a-1c, respectively. The DPA-Fc series, 1d-1f, was synthesized using the Pd-catalyzed Buchwald-Hartwig coupling between the arylaminoferrocene precursors, 2d-2f, and 1-bromo-4-methoxybenzene. Notably, no apparent differences have been observed in comparative ${ }^{1} \mathrm{H}$ NMR spectra of complexes $\mathbf{1 a}-\mathbf{1 f}$, viz. the $-\mathrm{OCH}_{3}$ and Cp signals (see Supporting Information). 


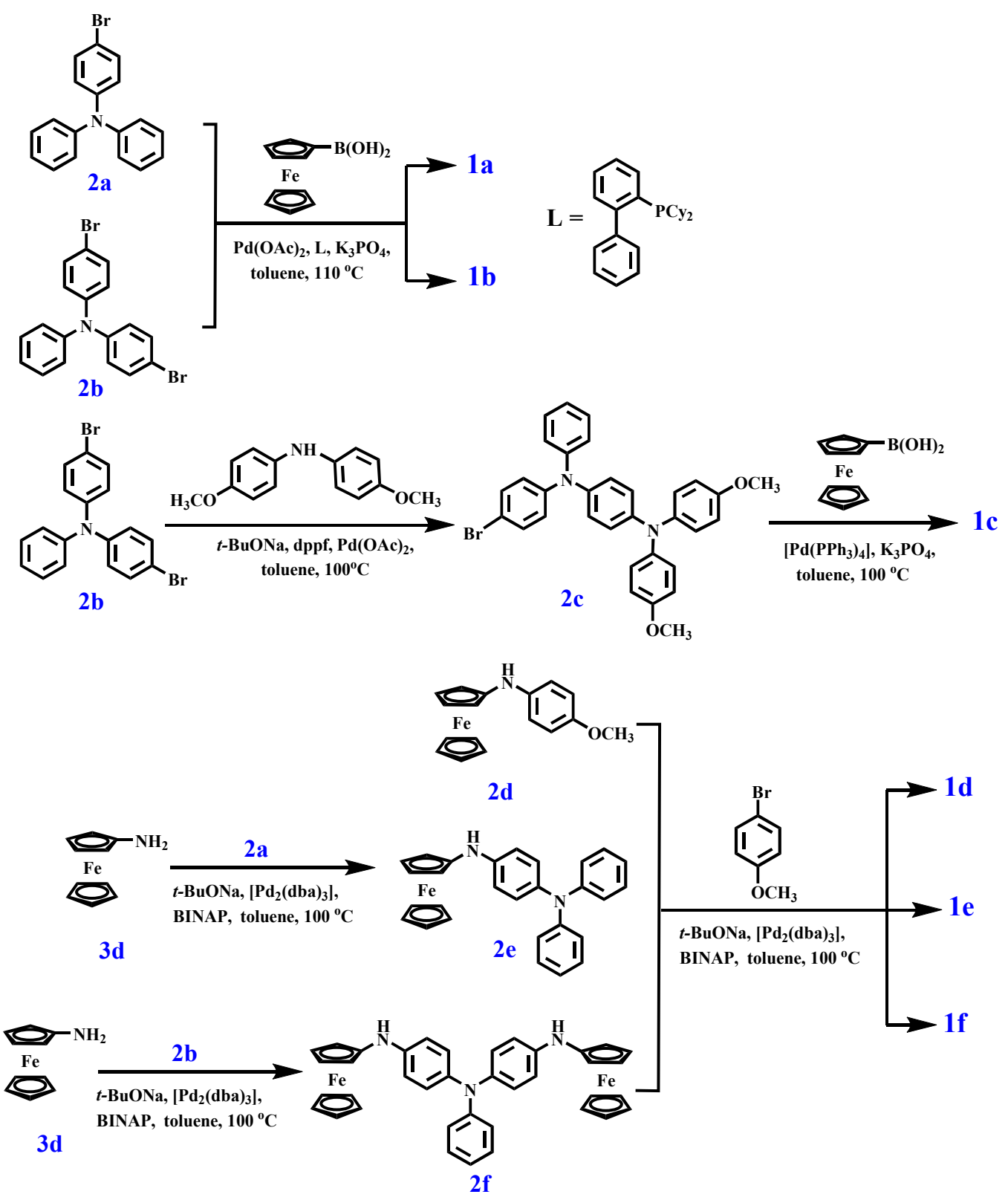

Scheme 1. Synthetic routes to complexes 1a-1f.

\section{X-ray Crystallography}

The molecular structure of solid complex 1d (Figure 1) has been resolved by single crystal X-ray diffraction. Suitable crystals of the complex were grown by slow evaporation of its dichloromethane solution at room temperature. Pertinent diffraction parameters are given in Tables 1 and S1 (see the Supporting Information). The pairs 
of C1(ferrocenyl)-N1-C18, C1(ferrocenyl)-N1-C11 and C11-N1-C18 angles are $124.0(2)^{\circ}, 114.3(2)^{\circ}$ and $117.4(2)^{\circ}$, respectively. Notably, some conjugation exists between the nitrogen atom and ferrocene, as indicated by the shorter $\mathrm{C} 1-\mathrm{N} 1$ bond of 1.411 (3) A compared to the N1-C11 and N1-C18 bonds of 1.439 (3), and 1.425 (3) $\AA$, respectively, as observed for other substituted triphenylamine systems. ${ }^{8 c, 10-13}$ The above trend and crystal data are consistent with the corresponding theoretical results obtained for the DFT (G09-B3LYP)-optimized structure presented in Table 1.

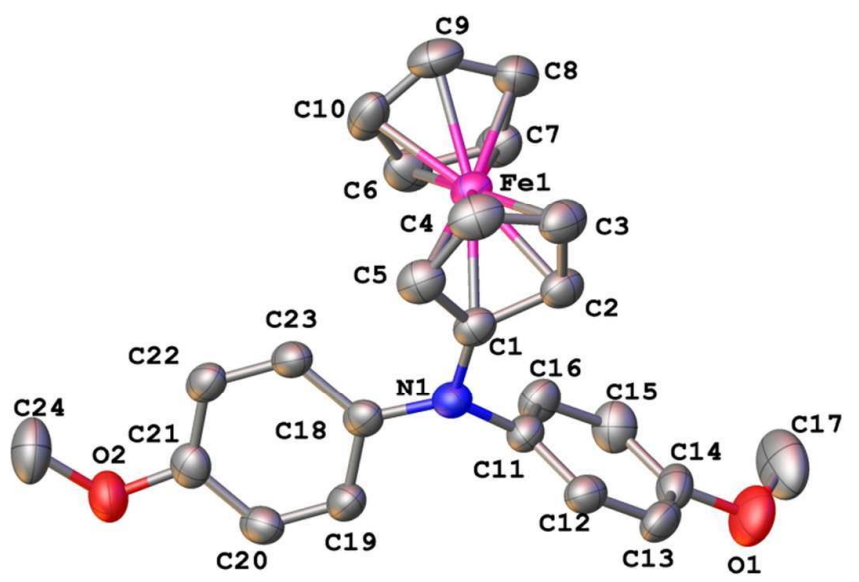

Figure 1. Thermal-ellipsoid plot of the X-ray structure of complex 1d (50\% probability). Hydrogen atoms have been omitted for clarity.

Table 1. Selected bond lengths $(\AA)$ and angles (deg) in the crystal structure and DFT (G09-B3LYP)-optimized structure of complex 1d.

\begin{tabular}{ccc}
\hline Parameter & Crystal & Calculated \\
\hline $\mathrm{C} 1-\mathrm{C} 2$ & $1.422(4)$ & 1.435 \\
$\mathrm{C} 2-\mathrm{C} 3$ & $1.416(4)$ & 1.430 \\
$\mathrm{C} 3-\mathrm{C} 4$ & $1.405(4)$ & 1.425 \\
$\mathrm{C} 4-\mathrm{C} 5$ & $1.421(4)$ & 1.430 \\
$\mathrm{C} 1-\mathrm{N} 1$ & $1.411(3)$ & 1.402 \\
$\mathrm{~N} 1-\mathrm{C} 11$ & $1.439(3)$ & 1.429 \\
$\mathrm{~N} 1-\mathrm{C} 18$ & $1.425(3)$ & 1.424 \\
$\mathrm{C} 11-\mathrm{C} 12$ & $1.383(3)$ & 1.398 \\
$\mathrm{C} 12-\mathrm{C} 13$ & $1.376(4)$ & 1.397 \\
$\mathrm{C} 13-\mathrm{C} 14$ & $1.378(4)$ & 1.399 \\
$\mathrm{C} 14-\mathrm{O} 1$ & $1.372(3)$ & 1.366 \\
$\mathrm{O} 1-\mathrm{C} 17$ & $1.408(4)$ & 1.417 \\
& 6 &
\end{tabular}




\begin{tabular}{ccc}
$\mathrm{C} 1-\mathrm{Fe} 1$ & $2.072(2)$ & 2.163 \\
$\mathrm{C} 1-\mathrm{N} 1-\mathrm{C} 11$ & $114.3(2)$ & 119.1 \\
$\mathrm{C} 1-\mathrm{N} 1-\mathrm{C} 18$ & $124.0(2)$ & 122.5 \\
\hline
\end{tabular}

\section{Electrochemical Properties}

The anodic behavior of complexes 1a-1f was investigated by cyclic voltammetry (CV) and square-wave voltammetry (SWV) in deaerated dichloromethane containing $10^{-1} \mathrm{M} n-\mathrm{Bu}_{4} \mathrm{NPF}_{6}$ as the supporting electrolyte (Figure 2). The relevant electrochemical data are summarized in Table 2.

The TPA-bridged bis(ferrocenyl) compound (1b) exhibits two reversible anodic waves, similarly to the voltammetric response of related monoferrocenyl-TPA (1a). However, the first anodic wave of $\mathbf{1 b}$ is relatively broad, consisting of two poorly resolved one-electron steps. The reference anodic potentials of free ferrocene and TPA (Figure S1, top) indicate that the initial oxidation process of both $\mathbf{1 a}$ and $\mathbf{1 b}$ is associated with the ferrocenyl units. The small separation of ca. $80 \mathrm{mV}$ between the two oxidations encompassed in the first anodic wave of $\mathbf{1} \mathbf{b}$ has been estimated as described in the literature. ${ }^{14}$ The two Fe(II) centers in $\mathbf{1 b}$ are oxidized nearly synchronously, reflecting a very weak electron communication between the ferrocenyl termini. This localized behavior closely resembles the initial two-electron oxidation reported for a TPA-bridged diethynyl diiron complex. ${ }^{4 a}$

The anodic voltammetric response of the M2TPPD-ferrocene complex, 1c, shows three reversible one-electron waves. We presume that only the first anodic step belongs to the oxidation of the ferrocenyl unit while the two subsequent oxidation processes are diamine-based, in agreement with outcomes of UV-vis-NIR spectroelectrochemistry and DFT calculations (vide infra). The second and third oxidation potentials of $\mathbf{1 c}$ are positively shifted compared to the symmetric methoxy-substituted TPPD (M4TPPD) ${ }^{4 \mathrm{~g}}$ reference (Figure S1, bottom), reflecting the presence of the oxidized ferrocenium unit in $[\mathbf{1 c}]^{+}$.

The DPA-Fc series, 1d-1f, is characterized by the first anodic process shifted negatively on the $\mathrm{Fc} / \mathrm{Fc}^{+}$potential scale to ca. $-0.30 \mathrm{~V}$, which corresponds to the 
oxidation of the $\mathrm{Fe}(\mathrm{II})$ centers as reported $^{8 \mathrm{c}}$ for (di-p-tolylamino)ferrocene. The negative potential shifts compared to 1a-1c reflect the donor capacity of the diphenylamino (DPA) substituent. Comparison with the literature ${ }^{8 \mathrm{c}}$ also facilitates the assignment of the irreversible anodic waves of complexes $\mathbf{1 d - 1 f}$ around $-0.8 \mathrm{~V}$ to the oxidation of DPA, generating a reactive $\mathrm{Fe}(\mathrm{III}) \mathrm{Cp}$-aminium diradical site in $[\mathbf{1 d}]^{2+}$. The preceding one-electron anodic steps seen in the voltammetric responses of $1 \mathbf{e}$ and 1f around $0.45 \mathrm{~V}$ correspond to the reversible oxidation of terminal and bridging TPA, respectively, being shifted less positively compared to $\mathbf{1 a}$ and $\mathbf{1 b}$ due to the donor DPA separating them from the pre-oxidized ferrocenium termini. This assignment is in line with the roughly $2: 1$ ratio of the anodic currents marking the initial ferrocene-based and subsequent TPA-based oxidations of dinuclear 1f (Figure 2). In summary, the anodic behavior of the ferrocenyl, DPA and TPA segments in 1d-1f can be classified as largely independent, with Cp-linked DPA acting as an effective donor substituent.

Table 2. Electrochemical data for complexes $\mathbf{1 a}-\mathbf{1 f}{ }^{a}$

\begin{tabular}{cccccc}
\hline \multirow{2}{*}{ Complex } & $E_{1 / 2}(1) / \mathrm{V}$ & $E_{1 / 2}(2) / \mathrm{V}$ & $E_{1 / 2}(3) / \mathrm{V}$ & $E_{1 / 2}(4) / \mathrm{V}$ & $E_{\mathrm{p}, \mathrm{a}}(5)(\mathrm{V})$ \\
& $\left(\Delta E_{\mathrm{p}}\right) / \mathrm{mV}$ & $\left(\Delta E_{\mathrm{p}}\right) / \mathrm{mV}$ & $\left(\Delta E_{\mathrm{p}}\right) / \mathrm{mV}$ & $\left(\Delta E_{\mathrm{p}}\right) / \mathrm{mV}$ & $b$ \\
\hline $\mathbf{1 a}$ & $-0.06(75)$ & -- & $0.60(80)$ & -- & -- \\
$\mathbf{1 b}$ & $-0.08^{c}$ & $-0.00^{c}$ & $0.67(70)$ & -- & -- \\
$\mathbf{1 c}$ & $0.06(60)$ & -- & $0.21(60)$ & $0.65(85)$ & -- \\
$\mathbf{1 d}$ & $-0.32(75)$ & -- & -- & -- & 0.77 \\
$\mathbf{1 e}$ & $-0.32(70)$ & -- & $0.45(70)$ & -- & 0.84 \\
$\mathbf{1 f}$ & $-0.33^{d}$ & $-0.33^{d}$ & $0.49(65)$ & -- & 0.83 \\
TPA & -- & -- & $0.54(90)$ & -- & -- \\
M4TPPD $^{4 \mathrm{~g}}$ & -- & -- & -0.06 & 0.45 & -- \\
\hline
\end{tabular}

${ }^{a}$ The anodic potentials and $\Delta E_{\mathrm{p}}$ values are referenced against the standard ferrocene/ferrocenium $\left(\mathrm{Fc} / \mathrm{Fc}^{+}\right)$redox couple. Under the experimental conditions used in this work, $E_{1 / 2}\left(\mathrm{Fc} / \mathrm{Fc}^{+}\right)=+0.49$ $\mathrm{V}$ vs $\mathrm{Ag} / \mathrm{Ag}^{+} .{ }^{b}$ Irreversible anodic wave. ${ }^{c}$ Based on the evaluation procedure described in ref. ${ }^{14}$ The measured $E_{\mathrm{p}}$ value (SWV, Figure 2 ) was $-0.8 \mathrm{~V}$ and the bandwidth was $130 \mathrm{mV}$. ${ }^{d}$ Unresolved two-electron anodic wave $\left(\Delta E_{1 / 2}<50 \mathrm{mV}\right)$. 


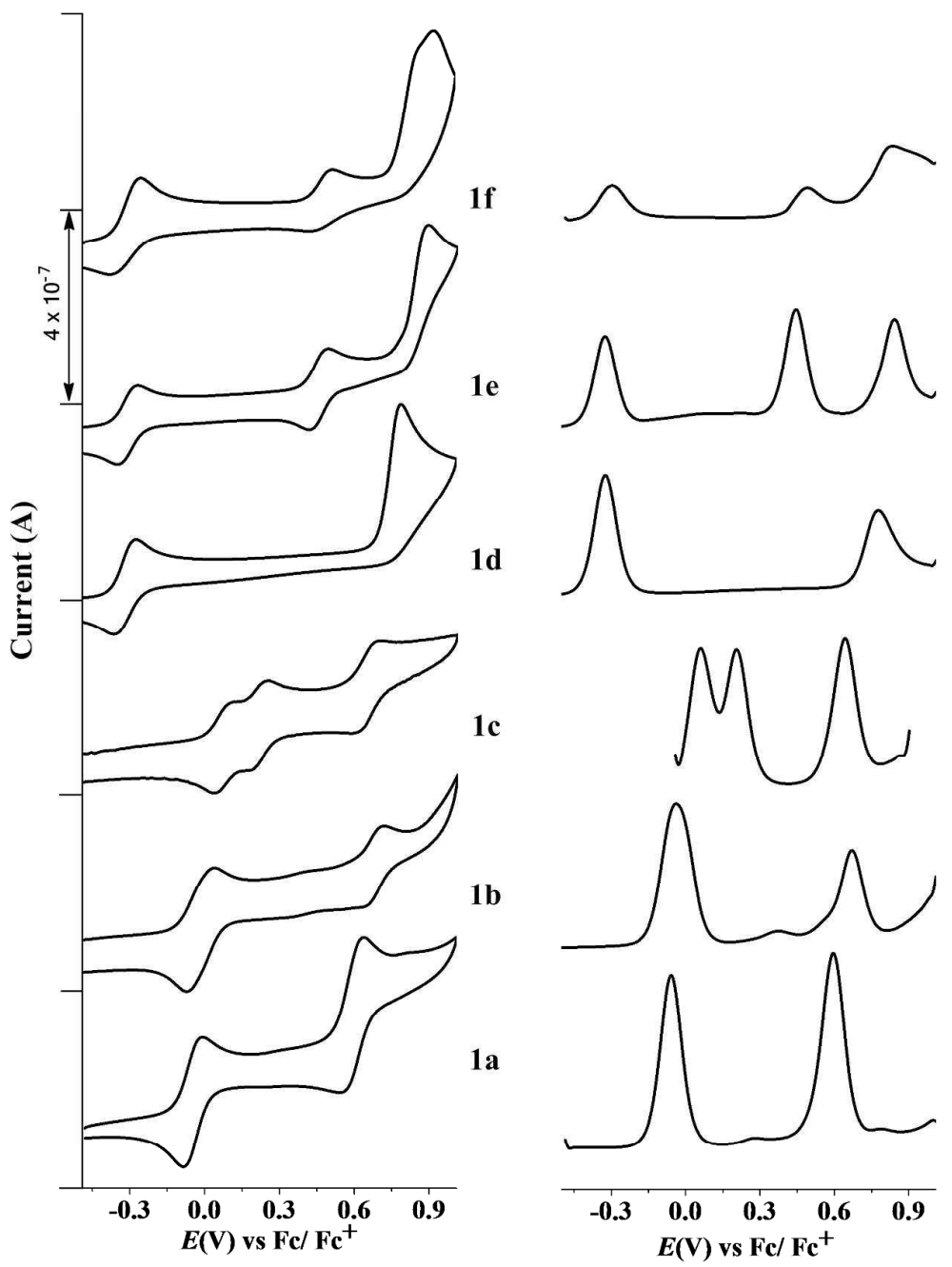

Figure 2. Left: cyclic voltammograms (CV) of complexes 1a-1f in $\mathrm{CH}_{2} \mathrm{Cl}_{2} / n-\mathrm{Bu}_{4} \mathrm{NPF}_{6}$ at $v=50$ $\mathrm{mV} \mathrm{s}^{-1}$. Right: corresponding square-wave voltammograms (SWV) of complexes 1a-1f at $f=10$ $\mathrm{Hz}$ and $t_{\mathrm{p}}=25 \mathrm{mV}$. The curtailed two-anodic-step CV of $\mathbf{1 f}$ is shown separately in Figure S2 (Supporting Information).

\section{UV-vis-NIR Spectroelectrochemistry}

UV-vis-NIR electronic absorption spectra of complexes 1a-1f in their different oxidation states were recorded by means of rapid in situ spectroelectrochemistry, as shown in Figures 3-5, and in Supporting Information, Figures S3-S6. The relevant wavenumbers and molar absorptivity at the absorption maxima are collected in Table 3. 
Smooth oxidation of (diphenylamino)phenylferrocene 1a to stable cationic species $[\mathbf{1 a}]^{+}$was accompanied by the appearance of two intense absorption bands between 25000 and $15000 \mathrm{~cm}^{-1}$ and a weaker NIR absorption around $7500 \mathrm{~cm}^{-1}$, along with a blue shift of the strong UV absorption (Figure 3, top). Not surprisingly, very similar changes in the electronic absorption were encountered during the initial two-electron oxidation of dinuclear $\mathbf{1 b}$ (Figure S3). The mixed-valence intermediate, $[\mathbf{1 b}]^{+}$, which is thermodynamically forced to disproportionate, appears in the potential-dependent spectral profile to absorb in the visible-NIR region at a slightly lower energy than the ultimate bis(ferrocenium) product, $[\mathbf{1 b}]^{2+}$. The subsequent oxidation of terminal TPA in $[\mathbf{1 a}]^{+}$(Figure 3 , bottom) and bridging TPA in $[\mathbf{1 b}]^{2+}$ was hard to compare due to poor solubility of $[\mathbf{1 b}]^{3+}$.

The products of the well-resolved stepwise one-electron oxidation of $1 \mathbf{c}$ to $[\mathbf{1 c}]^{3+}$ could be assigned straightforwardly with the aid of the spectrolectroelectrochemical monitoring. The second and third anodic steps (Figure 4, middle and bottom spectra, respectively) reside on the ancillary diamine group, as revealed by the very similar spectral changes accompanying oxidation of reference $\mathrm{M}_{4} \mathrm{TTPD}^{4 \mathrm{~g}}$ to the corresponding mono- and dianion (Figure S4). The initial anodic conversion of 1c to $[\mathbf{1 c}]^{+}$therefore involves the ferrocenyl Fe(II) center, similar to 1a. Accordingly, both $[\mathbf{1 a}]^{+}$and $[\mathbf{1 c}]^{+}$exhibit three pronounced absorption bands in the visible-NIR spectral region (Table 3), which can be assigned to the same kind of charge transfer electronic transitions (Table 4 in the following DFT section).

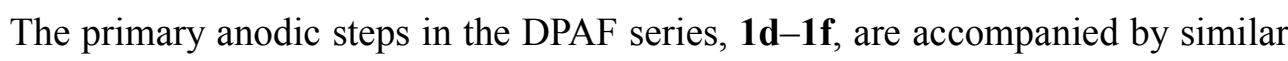
absorption changes in the visible-NIR region as encountered for the oxidation of $1 \mathrm{a}$ to $[\mathbf{1 a}]^{+}$, or dinuclear $\mathbf{1 b}$ to $[\mathbf{1 b}]^{2+}$. Thus, also $[\mathbf{1 d}]^{+}$(Figure S5), $[\mathbf{1 e}]^{+}$(Figure 5, top) and dinuclear $[\mathbf{1 f}]^{2+}$ (Figure S6) feature a low-lying weak absorption band between $10000-7000 \mathrm{~cm}^{-1}$ and a more intense one between $22000-20000 \mathrm{~cm}^{-1}$, in line with the generation of the aminoferrocenium moiety. The subsequent reversible oxidation of $[\mathbf{1 e}]^{+}$to $[\mathbf{1 e}]^{2+}$ (Figure 5 , bottom) involves admittedly the terminal TPA unit, the product resembling $[1 \mathbf{a}]^{2+}$ (Figure 3 , bottom) by the diminished NIR absorption and slightly blue-shifted absorption in the green spectral region. 
Table 3. UV-vis-NIR electronic absorption of complexes 1a-1f and their stable oxidized forms ${ }^{a}$ in dichloromethane $/ n-\mathrm{Bu}_{4} \mathrm{NPF}_{6}$.

\begin{tabular}{|c|c|}
\hline Complex & $v_{\max }\left(\mathrm{cm}^{-1}\right)\left(\varepsilon_{\max }\left(\mathrm{dm}^{3} \mathrm{~mol}^{-1} \mathrm{~cm}^{-1}\right)\right)$ \\
\hline $1 \mathbf{a}$ & $31330(20536)$ \\
\hline$[\mathbf{1} \mathbf{a}]^{+}$ & 33620 (20880), 23970 (5040), 19250 (7870), 7740 (3050) \\
\hline$[\mathbf{1 a}]^{2+}$ & $33690,19540,13680^{b}$ \\
\hline $1 \mathbf{b}$ & $30180(39220)$ \\
\hline$[\mathbf{1 b}]^{2+}$ & 33230 (38510), 24390 (11370), 19450 (17260), 8140 (7460) \\
\hline $1 \mathrm{c}$ & $30190(37800)$ \\
\hline$[\mathbf{1 c}]^{+}$ & $33790,23530,17280,10220^{c}, 6680$ \\
\hline$[\mathbf{1 c}]^{2+}$ & 23970 (21380), 16460 (7120), 9960 (26200) \\
\hline$[1 \mathrm{c}]^{3+}$ & $13800(37920)$ \\
\hline M4TPPD $^{d}$ & $32100(13420)$ \\
\hline$[\mathrm{M} 4 \mathrm{TPPD}]^{+d}$ & 24150 (7180), $16950(2210), 10360(8110)$ \\
\hline$[\mathrm{M} 4 \mathrm{TPPD}]^{2+d}$ & $14410(24160)$ \\
\hline $1 d$ & $35200(21360), 21700(5270)$ \\
\hline$[\mathbf{1 d}]^{+}$ & 35270 (23930), 27700 (8330), 21450 (7840), 19500 (sh), 9280 (2210) \\
\hline $1 \mathrm{e}$ & $33410(39360)$ \\
\hline$[1 \mathbf{e}]^{+}$ & 32790 (43130), 20310 (7050), $8510(2290)$ \\
\hline$[\mathbf{1 e}]^{2+}$ & 33340 (38510), 20990 (6910) \\
\hline 1f & $31140(21750)$ \\
\hline$[\mathbf{1 f}]^{2+}$ & 33750 (18880), 20920 (2980), 8840 (1090) \\
\hline
\end{tabular}

${ }^{a}$ The spectroelectrochemical results obtained for TPA-oxidized dinuclear species $[\mathbf{1 b}]^{3+}$ and $[\mathbf{1 f}]^{3+}$ were affected by low solubility of the trications in the electrolyte used, and, therefore, are not presented here. ${ }^{b}$ The molar absorptivity of $[\mathbf{1 a}]^{2+}$ was not determined due to low-solubility issues at the end of the anodic electrolysis. ${ }^{c}$ This absorption band most likely belongs to $[\mathbf{1} \mathbf{c}]^{2+}$ generated by partial redox disproportionation during the thin-layer electrolysis. The molar absorptivity of $[\mathbf{1 c}]^{+}$is not reported here. ${ }^{d}$ Ref. ${ }^{4 \mathrm{~g}}$. 

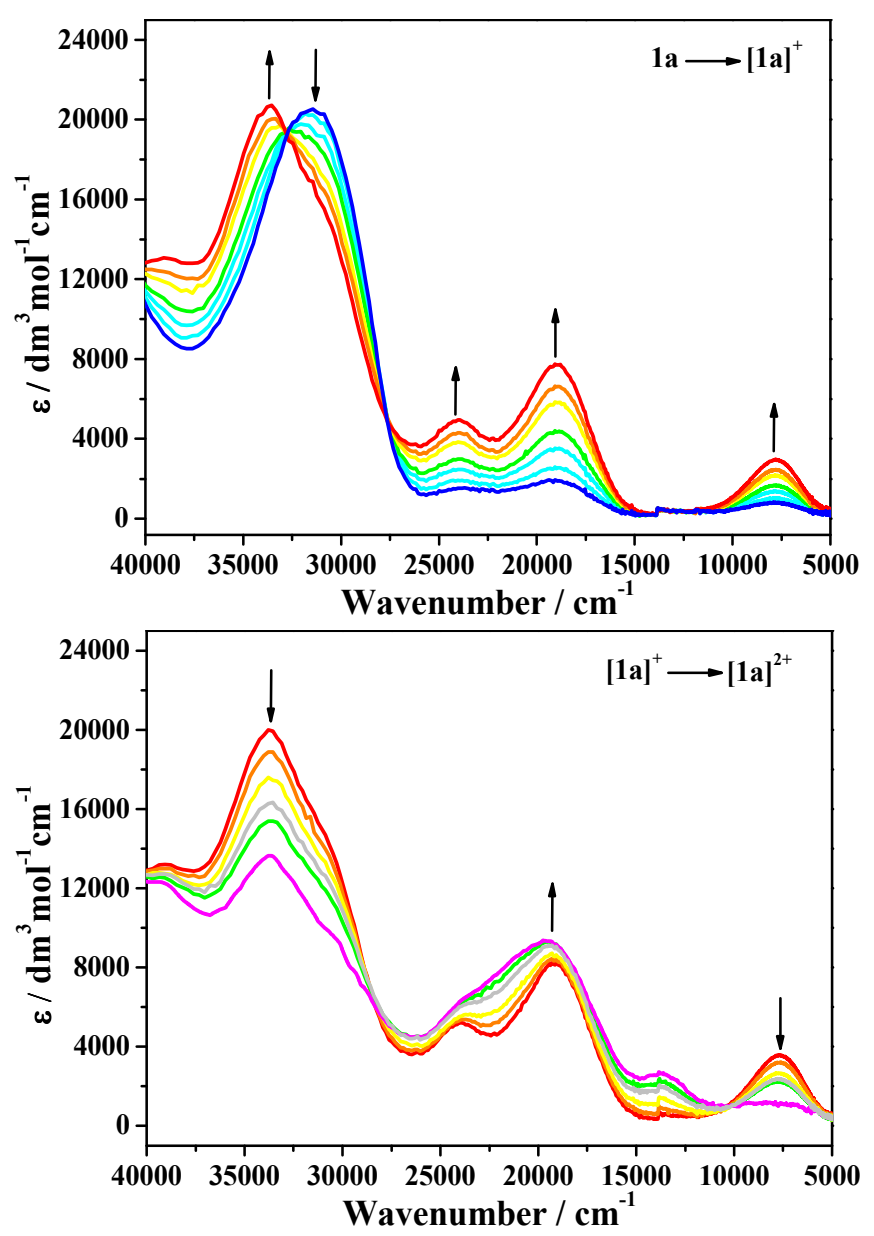

Figure 3. Changes in UV-vis-NIR absorption spectra recorded during the oxidation of complex 1a to $[\mathbf{1 a}]^{+}$(top) and $[\mathbf{1 a}]^{2+}$ (bottom) in $\mathrm{CH}_{2} \mathrm{Cl}_{2} / 10^{-1} \mathrm{M} n-\mathrm{Bu}_{4} \mathrm{NPF}_{6}$ at $298 \mathrm{~K}$ within an OTTLE cell. 

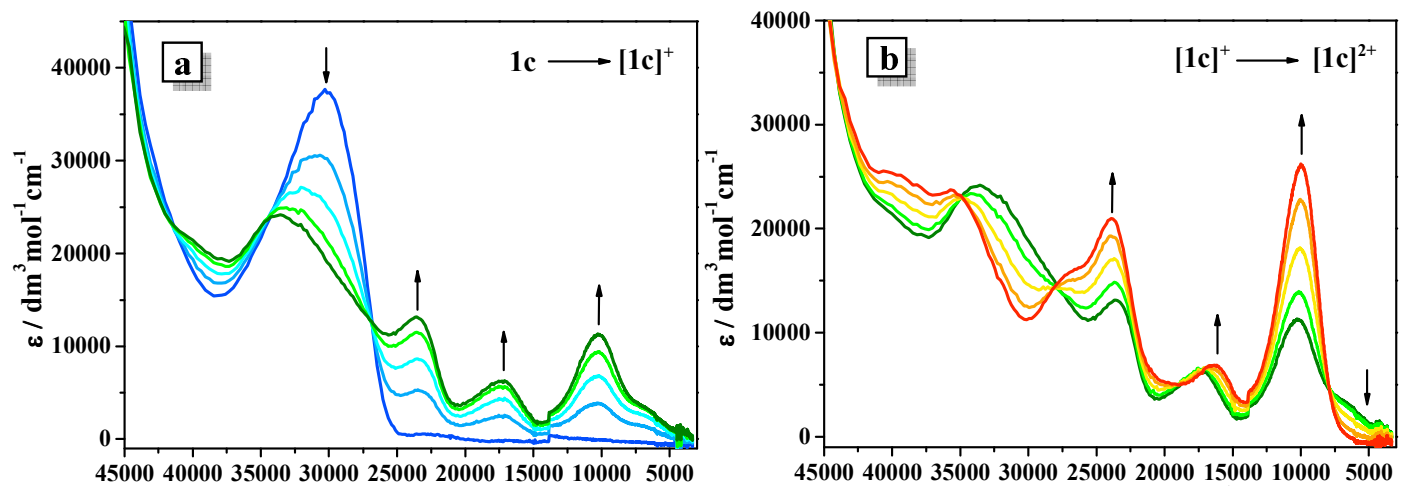

Wavenumber $/ \mathrm{cm}^{-1}$

Wavenumber $/ \mathrm{cm}^{-1}$

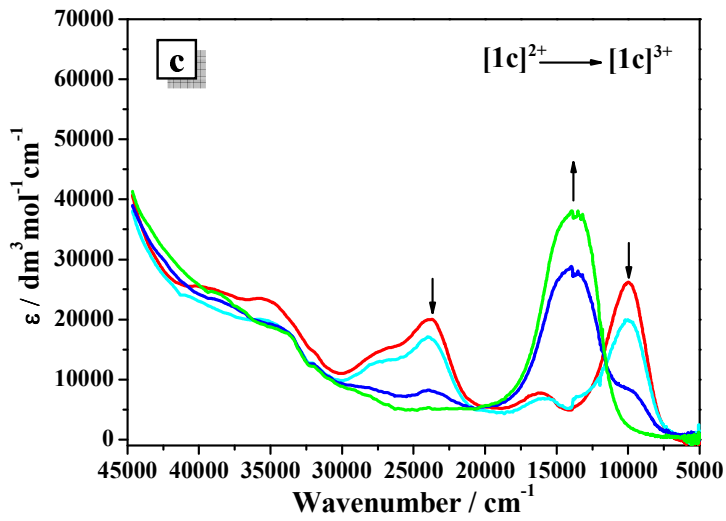

Figure 4. Changes in UV-vis-NIR absorption spectra recorded during the oxidation of complex 1c to $[\mathbf{1 c}]^{+}$(a), $[\mathbf{1 c}]^{2+}$ (b) and $[\mathbf{1 c}]^{3+}$ (c) in $\mathrm{CH}_{2} \mathrm{Cl}_{2} / 10^{-1} \mathrm{M} n-\mathrm{Bu}_{4} \mathrm{NPF}_{6}$ at $298 \mathrm{~K}$ within an OTTLE cell. 

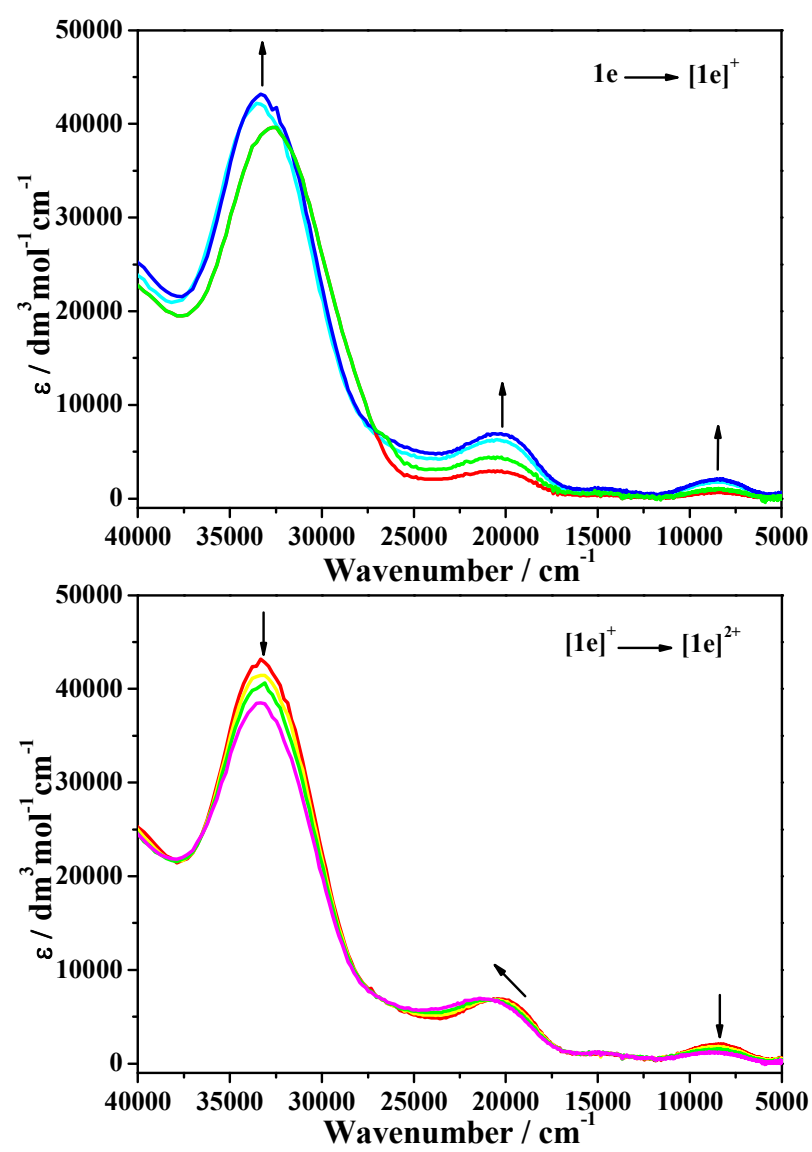

Figure 5. Changes in UV-vis-NIR absorption spectra recorded during the reversible oxidation of complex 1e to $[\mathbf{1 e}]^{+}$(top) and $[\mathbf{1 e}]^{2+}$ (bottom) in $\mathrm{CH}_{2} \mathrm{Cl}_{2} / 10^{-1} \mathrm{M} n-\mathrm{Bu}_{4} \mathrm{NPF}_{6}$ at $298 \mathrm{~K}$ within an OTTLE cell.

\section{Theoretical Calculations}

Density functional theory (DFT) calculations, using the B3LYP or CAM-B3LYP functionals, were performed to gain insight into the electronic structure of the one-electron-oxidized species $[\mathbf{1 a}]^{+}-[\mathbf{1 f}]^{+}$and selected mononuclear biradical dications $[\mathbf{1 a}]^{2+},[\mathbf{1 d}]^{2+}$ (unstable; Figure 2) and $[\mathbf{1 e}]^{2+}$. The basis set employed here is 6-31G* (Lanl2DZ for the Fe atom). To account for solvent effects, the conductor polarizable continuum model $(\mathrm{CPCM})$ in $\mathrm{CH}_{2} \mathrm{Cl}_{2}$ was employed for the ground-state structural optimization and analyses, as well as in the TD-DFT calculations of the electronic excitation energies. The pertinent data are presented in Figures 6-8 and Table 4, and in Supporting Information, Figures S7-S12.

The geometry-optimized DPAF derivatives, 1d-1f, (Figure S7) exhibit much 
shorter $\mathrm{N}-\mathrm{C}(\mathrm{Cp}$ ring) bonds (1.401-1.403 $\AA$ ) compared to the adjacent $\mathrm{N}-\mathrm{C}$ (phenyl) bonds $(1.424-1.429 \AA)$ and the normal N-C bonds $(1.421 \AA)$ in the TPA unit in 1e, in agreement with the crystal data for 1d (Table 1). These results indicate some conjugation between the redox-active ferrocenyl and DPA units, affecting the Fe(II) oxidation potential but not integrating them into one redox-active unit, in agreement with the preceding electrochemical section.

The spin density distribution in one-electron-oxidized $[\mathbf{1 a}]^{+}-[\mathbf{1 f}]^{+}$obtained with DFT is visualized in Figure 6. Importantly, in all these radical complexes, the spin density completely resides on (one of) the iron center(s), confirming the ferrocenyl-dominated initial oxidation steps, as indicated by the experimental voltammetric and spectroelectrochemical results. Regarding the dicationic dinuclear species, $\mathbf{1 b}]^{2+}$ and $[\mathbf{1 f}]^{2+}$, the symmetric bis(ferrocenium) biradical character is very clear from their electrochemical (Figure 2) and UV-vis-NIR absorption (Figure S3) characteristics.

The calculated distribution of the spin density in asymmetric mononuclear biradicals $[\mathbf{1 a}]^{2+},[\mathbf{1 d}]^{2+}$ and $[\mathbf{1 e}]^{2+}$ in their lowest-energy triplet ground states is shown in Figure 7. The data obtained for $[\mathbf{1} \mathbf{a}]^{2+}$ and $[\mathbf{1 e}]^{2+}$ prove the sequential ferrocenyl- and TAP-localized anodic steps deduced convincingly from the analysis of their voltammetric and spectroelectrochemical responses. The irreversible oxidation of $[\mathbf{1 d}]^{+}$to the reactive dication takes place, indeed, at the DPA site. Accordingly, the DPA site remains neutral in $[\mathbf{1 e}]^{2+}$, bridging between the energetically more accessible ferrocenium and $\mathrm{TAP}^{+}$sites. It becomes oxidized in the irreversible third anodic step, similar to the oxidation of $[\mathbf{1 d}]^{+}$(Figure 2 ). 


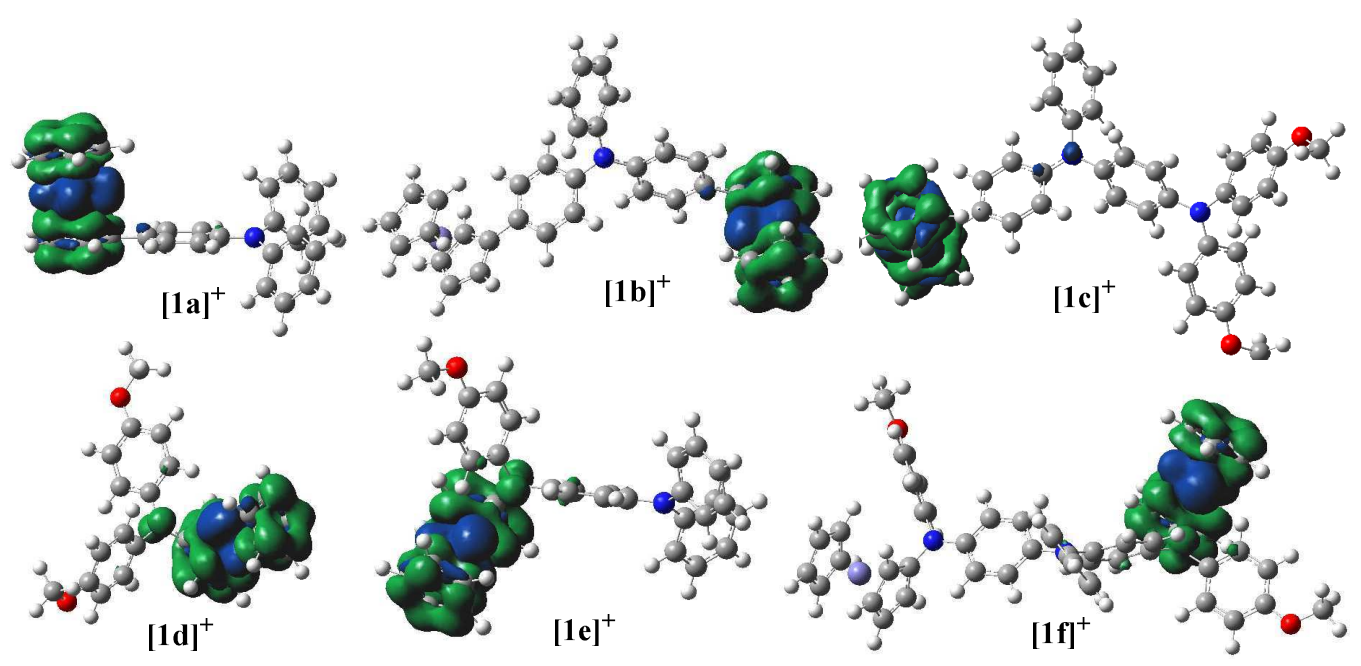

Figure 6. Calculated spin density distribution in $[\mathbf{1 a}]^{+}-[\mathbf{1 f}]^{+}$. Contour values: $\pm 0.02\left(\mathrm{e} / \mathrm{bohr}^{3}\right)^{1 / 2}$. B3LYP/6-31G*(Fe: Lan12DZ)/CPCM / $\mathrm{CH}_{2} \mathrm{Cl}_{2}$. CAM-B3LYP was used for [1 c $]^{+}$.

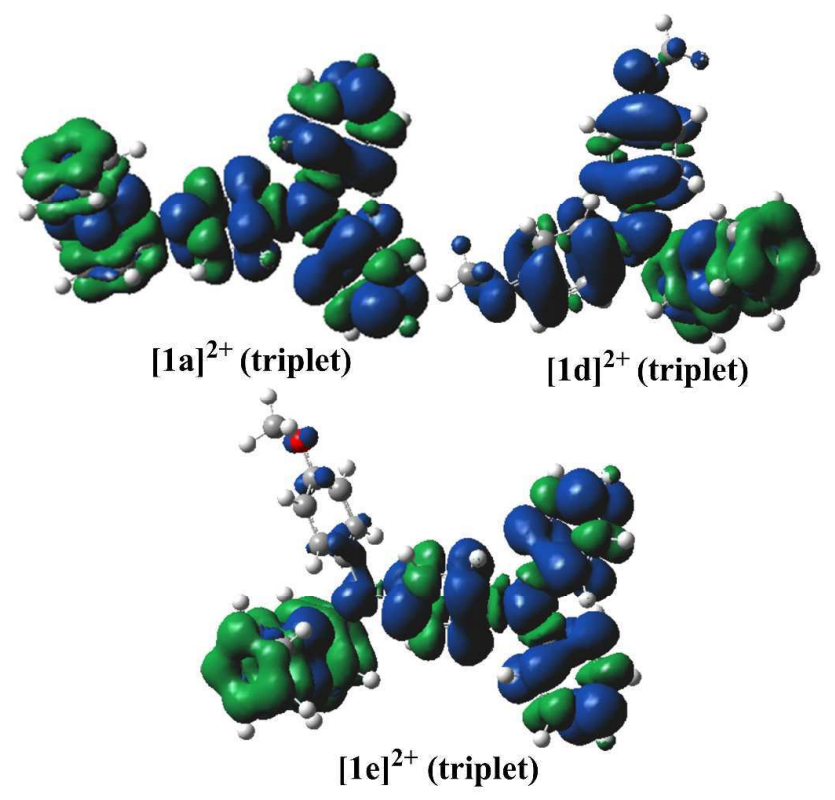

Figure 7. Calculated spin density distribution in biradicals $[\mathbf{1 a}]^{2+},[\mathbf{1 d}]^{2+}$ and $[\mathbf{1 e}]^{2+}$. Contour values: $\pm 0.02\left(\mathrm{e} / \mathrm{bohr}^{3}\right)^{1 / 2}$. B3LYP/6-31G*/CPCM $/ \mathrm{CH}_{2} \mathrm{Cl}_{2}$.

TD-DFT calculations were carried out to reproduce the low-energy absorption features in the experimental UV-vis-NIR spectra of the one- and two-electron-oxidized monoferrocenyl species, and to facilitate their assignment in 
support of the spin-localized bonding situation (Figures 6 and 7\}. The significant low-energy electronic transitions are presented in Table 4. According to the TD-DFT results, the characteristic absorption band of the monocationic species $[\mathbf{1 a}]^{+}-[\mathbf{1} \mathbf{f}]^{+}$ below $10000 \mathrm{~cm}^{-1}$ has been well reproduced, being consistently assigned to an electronic excitation within the amino-substituted ferrocenium site. ${ }^{15}$ This NIR band disappears upon further oxidation. The higher-energy visible absorptions of the monocations generally correspond to a charge transfer between the donor (di)amine (TPA, TPPD) and acceptor ferrocenium sites. The main B3LYP spin orbitals contributing to these electronic transitions in the stable mononuclear species are depicted in Figures S8 $\left([\mathbf{1 a}]^{+}\right)$and S9 $\left([\mathbf{1 d}]^{+}\right)$, and Figure 8 (right; $\left.[\mathbf{1 e}]^{+}\right)$. The $\beta$-HOSO is correctly localized on the TPA site in $[\mathbf{1} \mathbf{a}]^{+}$and $[\mathbf{1 e}]^{+}$, and the DPA site in $[\mathbf{1 d}]^{+}$. Notably, the B3LYP method indicated TPPD-dominated one-electron oxidation of 1c, which proved inconsistent with the spectro-electrochemical results. The alternative CAM-B3LYP method was applied successfully in this case. As a result, both the $\alpha$ - and $\beta$-LUSO of $[\mathbf{1 c}]^{+}$are ferrocenyl-localized whilst the $\beta$-HOSO resides on DTTP oxidizing in the following step to $[\mathbf{1 c}]^{2+}$. The spin orbitals participating in the low-energy optical excitation of $[\mathbf{1 c}]^{+}$are visualized in Figure 8 (left). The characteristic ferrocenium-based electronic transition around $7000 \mathrm{~cm}^{-1}$ (Table 4$)^{15}$ can be spotted in the experimental spectra in Figure $4(a, b)$ due to its disappearance upon the oxidation of $[\mathbf{1 c}]^{+}$to the corresponding dication. The absorption band at $10220 \mathrm{~cm}^{-1}$, not reproduced by the TD DFT calculations of $[\mathbf{1 c}]^{+}$, may reflect an early-stage partial redox disproportionation of the monocation to $[\mathbf{1} \mathbf{c}]^{2+}$ absorbing in this region (Figure 4b). The anodic potential difference between the initial two oxidations of 1c is indeed small (Figure 2), becoming less resolved at the higher concentration used for the spectroelectrochemical experiment.

The visible electronic excitation of stable triplet biradical $[\mathbf{1 a}]^{2+}$ involves occupied and empty frontier spin orbitals of $\mathrm{TPA}^{+}$with a variable subordinate contribution from phenylferrocenium; the excitation at ca $500 \mathrm{~nm}$ is exceptional, featuring a strong $\mathrm{TPA}^{+}$-to-phenylferrocenium charge transfer character (Figure S10). In contrast, the electronic absorption of $[\mathbf{1 e}]^{2+}$ in the visible region is dominated by 
the charge transfer from the non-oxidized donor (Cp)DPA bridge to the $\mathrm{TPA}^{+}$moiety. Importantly, also the $\beta$-HOSO of $[\mathbf{1} \mathbf{e}]^{2+}$ is dominantly DPA-localized (Figure S12), in agreement with the irreversible oxidation to $[\mathbf{1 e}]^{3+}$. Finally, unstable $[\mathbf{1 d}]^{2+}$ was also calculated to confirm the DPA-based (irreversible) oxidation of the cationic precursor (Figure S11). Its electronic excitation has been predicted (a) in the NIR region (ca 950 $\mathrm{nm}$ ), having a strong $\mathrm{DPA}^{+}$intra-ligand character, with a subordinate contribution from a charge transfer to the $\mathrm{N}-\mathrm{CpFe}^{+}$part, and (b) in the visible region (ca $600 \mathrm{~nm}$ ) featuring a mixed $\mathrm{DPA}^{+}$-to-ferrocenium charge transfer and $\mathrm{DPA}^{+}$intraligand absorption.

Table 4. Major electronic excitations in complexes $[\mathbf{1 a}]^{+}-[\mathbf{1} \mathbf{f}]^{+}$and $[\mathbf{1 a}]^{2+},[\mathbf{1 d d}]^{2+},[\mathbf{1 e}]^{2+}$ determined by the TD-DFT method. ${ }^{a}$

\begin{tabular}{|c|c|c|c|c|c|c|}
\hline Complex & $\begin{array}{l}\text { Excited } \\
\text { State }\end{array}$ & $\begin{array}{l}v\left(\mathrm{~cm}^{-1}\right) \\
{[\lambda(\mathrm{nm})]}\end{array}$ & $\begin{array}{c}\text { Osc. } \\
\text { Strength } \\
(f)\end{array}$ & Major Contributions & Assignment & $\begin{array}{c}v_{\exp } \\
\left(\mathrm{cm}^{-1}\right)^{b}\end{array}$ \\
\hline \multirow{3}{*}[\mathbf{1a}]{$^{+}$} & $D_{2}$ & $\begin{array}{c}8530 \\
{[1172]}\end{array}$ & 0.071 & $\begin{array}{c}\beta \text {-HOSO- } 6 \rightarrow \beta \text {-LUSO } \\
(84 \%)\end{array}$ & $\mathrm{Fe} \rightarrow \mathrm{Fc}^{+}-\mathrm{Ph}$ & 7740 \\
\hline & $D_{4}$ & $\begin{array}{l}14180 \\
{[705]}\end{array}$ & 0.2908 & $\begin{array}{c}\alpha-\mathrm{HOSO} \rightarrow \alpha \text {-LUSO } \\
(56 \%) \\
\beta-\mathrm{HOSO} \rightarrow \beta \text {-LUSO } \\
(26 \%)\end{array}$ & $\mathrm{TPA} \rightarrow \mathrm{Fc}^{+}-\mathrm{Ph}$ & 19250 \\
\hline & $D_{10}$ & $\begin{array}{l}21050 \\
{[475]} \\
\end{array}$ & 0.2707 & $\begin{array}{c}\beta \text {-HOSO } \rightarrow \beta \text {-LUSO }+1 \\
(70 \%)\end{array}$ & $\mathrm{TPA} \rightarrow \mathrm{Fc}^{+}-\mathrm{Ph}$ & 23970 \\
\hline \multirow{3}{*}{$\begin{array}{c}{[\mathbf{1} \mathbf{a}]^{2+}} \\
\text { (biradical) }\end{array}$} & $D_{3}$ & $\begin{array}{l}13990 \\
{[715]}\end{array}$ & 0.1024 & $\begin{array}{c}\beta \text {-HOSO } \rightarrow \beta \text {-LUSO } \\
(64 \%) \\
\beta \text {-HOSO- } 2 \rightarrow \beta \text {-LUSO } \\
(36 \%)\end{array}$ & $\begin{array}{c}\mathrm{Fc}^{+} / \mathrm{TPA}^{+} \rightarrow \mathrm{TPA}^{+} \\
\mathrm{TPA}^{+} \text {localized }\end{array}$ & 13680 \\
\hline & $D_{6}$ & $\begin{array}{l}17010 \\
{[588]}\end{array}$ & 0.1361 & $\begin{array}{c}\beta \text {-HOSO- } 3 \rightarrow \beta \text {-LUSO } \\
(67 \%)\end{array}$ & $\mathrm{TPA}^{+}$localized & $19540^{c}$ \\
\hline & $D_{12}$ & $\begin{array}{l}20160 \\
{[496]}\end{array}$ & 0.1375 & $\begin{array}{c}\alpha-\mathrm{HOSO} \rightarrow \alpha-\text {-LUSO } \\
(64 \%)\end{array}$ & $\mathrm{TPA}^{+} \rightarrow \mathrm{Fc}^{+}-\mathrm{Ph}$ & $19540^{c}$ \\
\hline \multirow[t]{2}{*}[\mathbf{1b}]{$^{+}$} & $D_{2}$ & $\begin{array}{c}8500 \\
{[1177]}\end{array}$ & 0.0108 & $\begin{array}{c}\beta \text {-HOSO- } 13 \rightarrow \beta \text {-LUSO } \\
(72 \%) \\
\beta \text {-HOSO- } 12 \rightarrow \beta \text {-LUSO } \\
(15 \%)\end{array}$ & $\begin{array}{c}\mathrm{Fe} \rightarrow \mathrm{Fc}^{+}-\mathrm{Ph} \\
\mathrm{Fc}-\mathrm{TPA} \rightarrow \mathrm{Fc}^{+}-\mathrm{Ph}\end{array}$ & $7450^{d}$ \\
\hline & $D_{8}$ & $\begin{array}{l}13530 \\
{[739]}\end{array}$ & 0.2971 & $\begin{array}{c}\alpha-\mathrm{HOSO} \rightarrow \alpha \text {-LUSO } \\
(48 \%)\end{array}$ & $\begin{array}{c}\mathrm{Fc}-\mathrm{TPA} \rightarrow \mathrm{Fc}^{+}-\mathrm{Ph} \\
\mathrm{LMCT} / \mathrm{ILCT}\end{array}$ & $18160^{d}$ \\
\hline
\end{tabular}


$\beta$-HOSO $\rightarrow \beta$-LUSO

$(29 \%)$

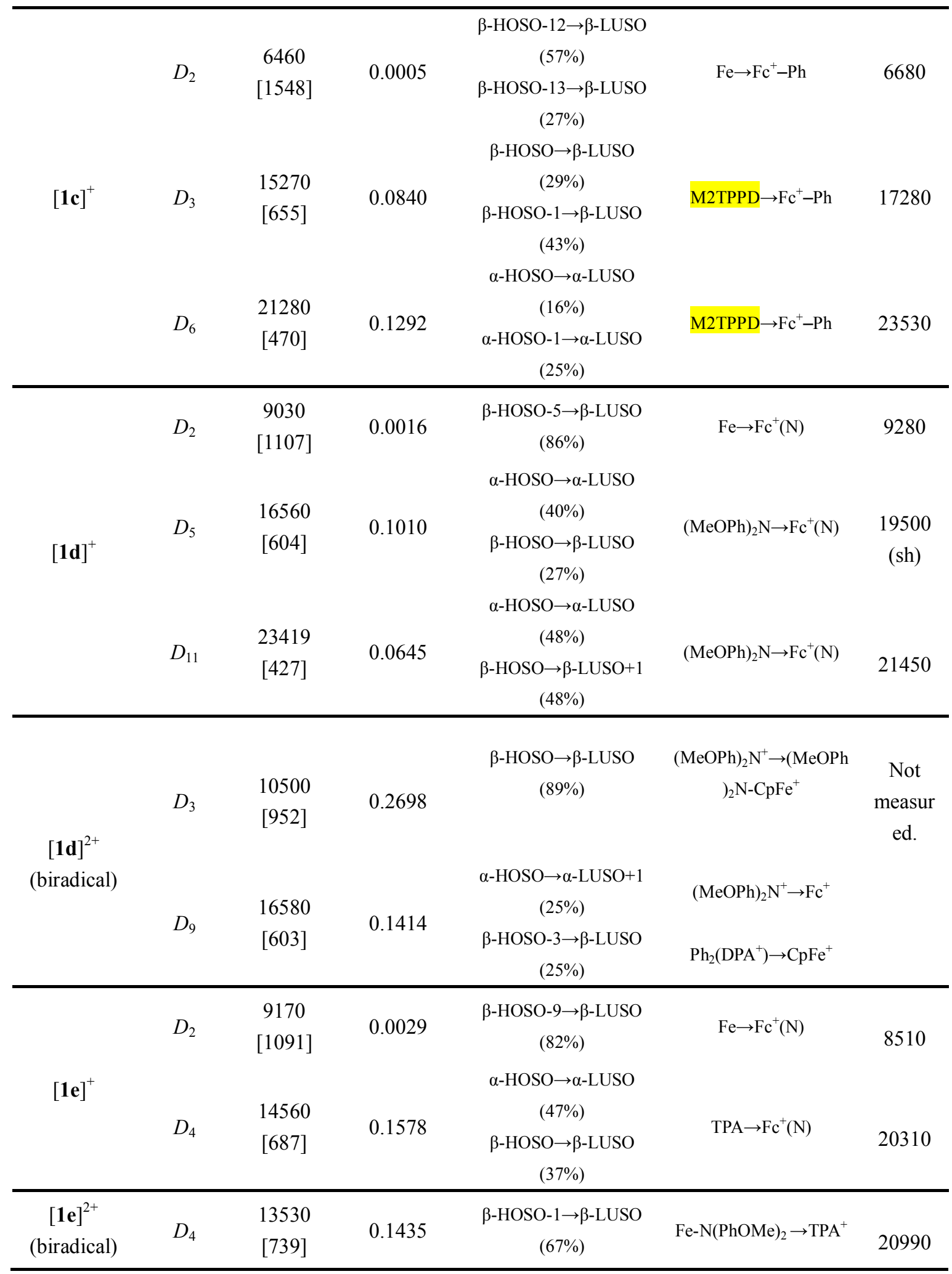

${ }^{a}$ B3LYP/6-31G*(Fe: Lanl2DZ)/CPCM / $\mathrm{CH}_{2} \mathrm{Cl}_{2}$. CAM-B3LYP was used for $[\mathbf{1 c}]^{+} .{ }^{b}$ Taken from

Table 3. ${ }^{c}$ Asymmetric broad band encompassing the two calculated electronic transitions. ${ }^{d}[\mathbf{1 b}]^{+}$ 
undergoes redox disproportionation (Table 2) and the absorption maxima listed in Table 4 correspond to the initial phase of the anodic electrolysis.

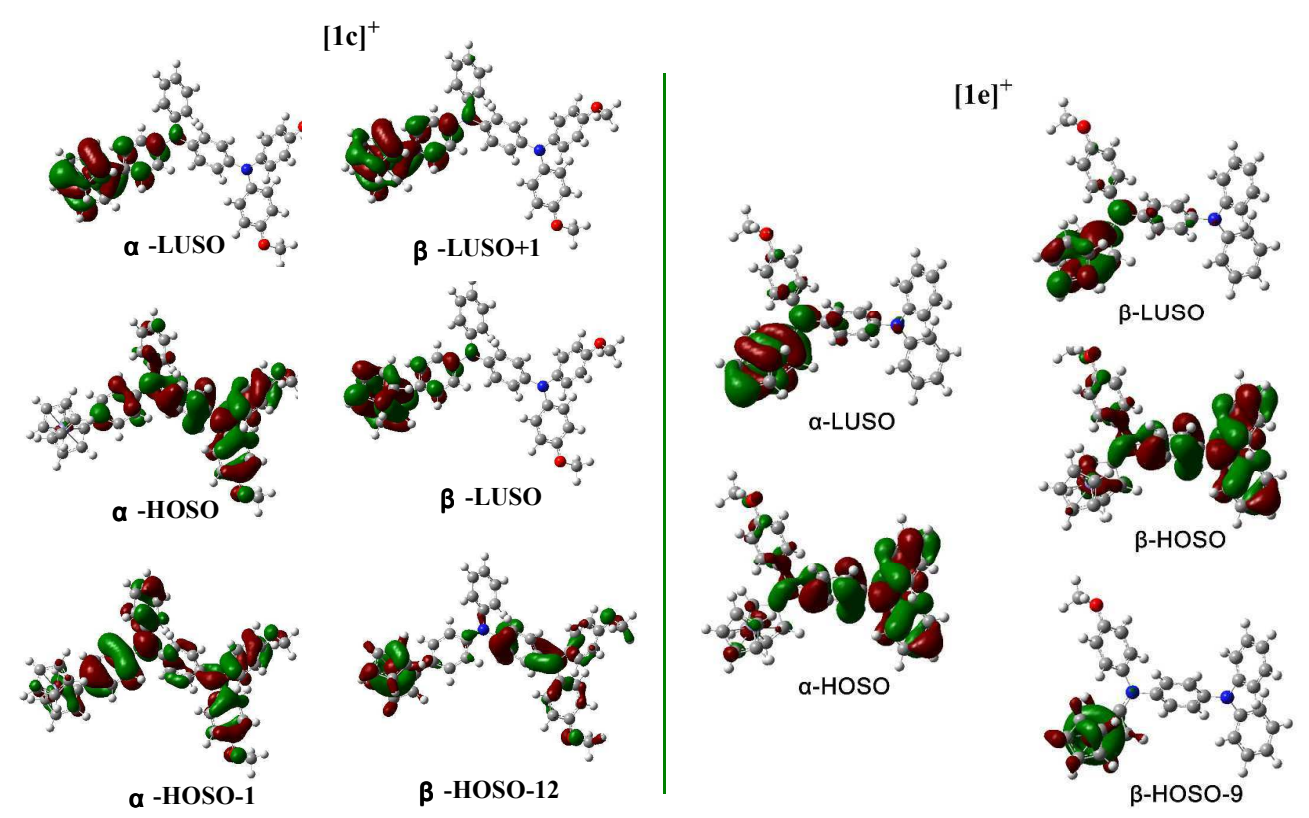

Figure 8. Spin orbitals involved in the major electronic excitations of $[\mathbf{1 c}]^{+}$(left) and $[\mathbf{1 e}]^{+}$(right) presented in Table 4. CAM-B3LYP $\quad\left([\mathbf{1 c}]^{+}\right)$or B3LYP $\left([\mathbf{1 e}]^{+}\right) / 6-31 \mathrm{G}^{*} \quad(\mathrm{Fe}$ : Lanl2DZ)/CPCM/ $/ \mathrm{CH}_{2} \mathrm{Cl}_{2}$.

\section{Conclusions}

This work presents a series of mono- and bis(ferrocenyl)-substituted TPA (1a, 1b), TPPD (1c), and Cp-DPA (1d-1f) derivatives depicted in Chart 1. The electrochemical and UV-vis-NIR spectroelectrochemical results have consistently revealed that the first anodic steps for $\mathbf{1 a}-\mathbf{1 f}$ is associated with one-electron oxidation of the ferrocenyl units, being followed by donor TPA substituents (absent in 1d) and, finally, Cp-bound DPA (or diphenylferrocenyl amine). The latter donor segments oxidize irreversibly and facilitate the preceding ferrocenyl oxidation. TD-DFT calculations at the B3LYP or CAM-B3LYP levels (successfully applied for reference phenylferrocenium) have disclosed that the characteristic absorption bands of the monocationic radical species $[\mathbf{1 a}]^{+}-[\mathbf{1 e}]^{+}$in the near-IR region involve excitation within the oxidized ferrocenium site; the anticipated amine-to-ferrocenium 
charge-transfer absorption has been encountered in the visible spectral region. Mononuclear biradicals $[\mathbf{1 a}]^{2+},[\mathbf{1 d}]^{2+}$ (unstable) and $[\mathbf{1 e}]^{2+}$ reside in a triplet ground state. The symmetric TPA-bridged diferrocenyl, $\mathbf{1 b}$, and bis(phenylaminoferrocenyl), 1f, complexes behave as localized redox systems with minimal interaction between the iron centres, undergoing facile redox disproportionation in the one-electron-oxidized state. We trust that new insights obtained from detailed studies of such systems containing multiple redox-responsive components will further advance rational design, understanding and exploration of new systems in materials chemistry based on electron-rich substituted ferrocenes.

\section{Experimental Section}

General Materials. All manipulations were carried out under a dry argon gas atmosphere by using standard Schlenk techniques, unless stated otherwise. Solvents were pre-dried and distilled under argon prior to use, except those used directly for spectroscopic measurements, which were of spectroscopic grade. The starting materials (4-bromophenyl)diphenylamine $(\mathbf{2 a})^{16}$, bis(4-bromophenyl)phenylamine (2b) ${ }^{16}, \quad$ bis(4-methoxyphenyl)amine $e^{17}, \quad N$-ferrocenyl-4-methoxyaniline $(\mathbf{2 d})^{18}$ and aminoferrocene (3d) ${ }^{19}$ were prepared by the procedures described in the literatures. Target complexes 1a-1f were prepared along the synthetic route presented in Scheme 1. Other reagents were purchased and used as received.

Syntheses. Intermediate $2 c$. Bis(4-methoxyphenyl)amine (200 mg, $0.87 \mathrm{mmol}$ ), bis(4-bromophenyl)phenylamine (1.06 g, $2.60 \mathrm{mmol}), t$-BuONa (126 mg, $1.30 \mathrm{mmol}$ ), $\mathrm{Pd}(\mathrm{OAc})_{2}$ (3.9 mg, $0.017 \mathrm{mmol}$ ), and 1,1'-bis(diphenylphosphino)ferrocene (dppf) (24 $\mathrm{mg}, 0.04 \mathrm{mmol}$ ) were suspended in $5 \mathrm{~mL}$ of toluene. The resulting reaction mixture was stirred at $100{ }^{\circ} \mathrm{C}$ under nitrogen atmosphere for $36 \mathrm{~h}$. After the reaction mixture was cooled to ambient temperature, the crude product was purified by column chromatography (eluent: petroleum ether/ethyl acetate, 20/1). After recrystallization from methanol, the product was obtained as light yellow solid. Yield: $336 \mathrm{mg}$ (70\%). ${ }^{1} \mathrm{H}$ NMR (400 MHz, $\left.\mathrm{CDCl}_{3}\right): \delta 3.75\left(\mathrm{~s}, 6 \mathrm{H}, \mathrm{OCH}_{3}-\mathrm{H}\right), 6.79-7.25(\mathrm{~m}, 21 \mathrm{H}, \mathrm{Ar}-\mathrm{H}) .{ }^{13} \mathrm{C}$ NMR $\left(100 \mathrm{MHz}, \mathrm{CDCl}_{3}\right): \delta 55.5\left(\mathrm{OCH}_{3}\right), 114.5,121.5-121.8,122.4,123.5-124.3$, 
126.2, 129.0, 131.7, 131.9, 139.7, 139.9, 147.0, 155.5 (Ar). Anal. Calcd for $\mathrm{C}_{32} \mathrm{H}_{27} \mathrm{BrN}_{2} \mathrm{O}_{2}: \mathrm{C}, 69.69 ; \mathrm{H}, 4.94 ; \mathrm{N}, 5.08$. Found: C, 69.85; H, 4.89; N, 5.13.

Intermediate $2 \boldsymbol{e}$. Aminoferrocene (173 $\mathrm{mg}, 0.90 \quad \mathrm{mmol})$, (4-bromophenyl)diphenylamine (279 mg, $0.90 \mathrm{mmol}$ ), $t$-BuONa (248 mg, $2.60 \mathrm{mmol}$ ), $\mathrm{Pd}_{2}(\mathrm{dba})_{3}(32 \mathrm{mg}, 0.030 \mathrm{mmol}$ ), and (+/-)-2,2'-bis(diphenylphosphino)-1,1'-binaphthyl (BINAP) (19 mg, $0.030 \mathrm{mmol}$ ) were suspended in $5 \mathrm{~mL}$ of toluene. The resulting reaction mixture was stirred at $100{ }^{\circ} \mathrm{C}$ under nitrogen atmosphere for $72 \mathrm{~h}$. After the reaction mixture was cooled to ambient temperature, the crude product was purified by column chromatography (eluent: petroleum ether/ethyl acetate, 60/1). The pure product was obtained as yellow solid. Yield: $172 \mathrm{mg}$ (45\%). ${ }^{1} \mathrm{H}$ NMR (400 MHz, $\left.\mathrm{CDCl}_{3}\right): \delta 4.13(\mathrm{~s}, 2 \mathrm{H}, \mathrm{Fc}-\mathrm{H}), 4.22(\mathrm{~s}, 5 \mathrm{H}, \mathrm{Fc}-\mathrm{H}), 4.31(\mathrm{~s}, 2 \mathrm{H}, \mathrm{Fc}-\mathrm{H}), 6.69(\mathrm{~s}, 1 \mathrm{H}$, $\mathrm{N}-\mathrm{H}), 6.87-6.90$ (t, $J=12 \mathrm{~Hz}, 2 \mathrm{H}, \operatorname{Ar}-\mathrm{H}), 7.00-7.02$ (d, $J=8 \mathrm{~Hz}, 6 \mathrm{H}, \operatorname{Ar}-\mathrm{H})$, 7.16-7.22 (m, 6H, Ar-H). ${ }^{13} \mathrm{C}$ NMR (100 MHz, $\left.\mathrm{CDCl}_{3}\right): \delta 61.7,64.5,68.8(\mathrm{Fc}), 100.6$, $115.6,121.4,122.5,127.0,128.8,138.8,142.2,147.9$ (Ar). Anal. Calcd for $\mathrm{C}_{28} \mathrm{H}_{24} \mathrm{FeN}_{2}$ : C, 75.68; H, 5.44; N, 6.30. Found: C, 75.43; H, 5.37; N, 6.22.

Intermediate $2 \boldsymbol{f}$. Aminoferrocene (201 $\mathrm{mg}, 1.00 \mathrm{mmol})$, bis(4-bromophenyl)phenylamine (202 mg, $0.50 \mathrm{mmol}), t$-BuONa (144 mg, 1.50 mmol), $\operatorname{Pd}_{2}(\mathrm{dba})_{3}(18 \mathrm{mg}, 0.02 \mathrm{mmol})$, and BINAP (13mg, $\left.0.02 \mathrm{mmol}\right)$ were suspended in $5 \mathrm{~mL}$ of toluene. The resulting reaction mixture was stirred at $100{ }^{\circ} \mathrm{C}$ under nitrogen atmosphere for $55 \mathrm{~h}$. After the reaction mixture was cooled to ambient temperature, the crude product was purified by column chromatography (eluent: petroleum ether/ethyl acetate, 10/1). After recrystallization from hexane, the product was obtained as yellow solid. Yield: $128 \mathrm{mg}(40 \%) .{ }^{1} \mathrm{H}$ NMR (600 MHz, $\left.\mathrm{CDCl}_{3}\right): \delta$ 4.07 (s, 4H, Fc-H), 4.20 (s, 10H, Fc-H), 4.26 (s, 4H, Fc-H), 4.45 (s, 2H, N-H), 6.97-7.16 (m, 13H, Ar-H). ${ }^{13} \mathrm{C}$ NMR (100 MHz, DMSO- $\left.d_{6}\right): \delta 59.3,63.4,68.3(\mathrm{Fc})$, 101.4, 115.1, 118.1, 126.3, 128.6, 137.2, 142.0, 148.7 (Ar). Anal. Calcd for $\mathrm{C}_{38} \mathrm{H}_{33} \mathrm{Fe}_{2} \mathrm{~N}_{3}$ : C, 70.94; H, 5.17; N, 6.53. Found: C, 70.65; H, 5.08; N, 6.58.

Target complexes 1a-1f were prepared along the synthetic route presented in Scheme 1.

Preparation of 4-(diphenylamino)phenylferrocene, $\mathbf{1 a}$. (4-Bromophenyl)diphenylamine (235 mg, $0.73 \mathrm{mmol})$, ferrocenylboronic acid (200 $\mathrm{mg}, 0.87 \mathrm{mmol}), \mathrm{K}_{3} \mathrm{PO}_{4}(462 \mathrm{mg}, 2.20 \mathrm{mmol}), \mathrm{Pd}(\mathrm{OAc})_{2}(1.6 \mathrm{mg}, 0.007 \mathrm{mmol})$, and 2-(dicyclohexylphosphino)biphenyl ( $5 \mathrm{mg}, 0.015 \mathrm{mmol})$ were suspended in $5 \mathrm{~mL}$ of 
toluene. The resulting reaction mixture was stirred at $110{ }^{\circ} \mathrm{C}$ under nitrogen atmosphere for $36 \mathrm{~h}$. After the reaction mixture was cooled to ambient temperature, the crude product was purified by column chromatography (eluent: dichloromethane/petroleum ether 3:10 (v/v)). After recrystallization from methanol, the product was obtained as yellow solid. Yield: $177 \mathrm{mg}(56 \%) .{ }^{1} \mathrm{H}$ NMR $(600 \mathrm{MHz}$, $\left.\mathrm{CDCl}_{3}\right): \delta 4.06(\mathrm{~s}, 5 \mathrm{H}, \mathrm{Fc}-\mathrm{H}), 4.28(\mathrm{~s}, 2 \mathrm{H}, \mathrm{Fc}-\mathrm{H}), 4.58(\mathrm{~s}, 2 \mathrm{H}, \mathrm{Fc}-\mathrm{H}), 7.01$ (t, $J=12$ Hz, 4H, Ar-H), 7.11 (d, $J=6$ Hz, 4H, Ar-H), 7.24-7.27 (m, 4H, Ar-H), 7.34-7.35 (d, $J$ $=6 \mathrm{~Hz}, 2 \mathrm{H}, \mathrm{Ar}-\mathrm{H}) .{ }^{13} \mathrm{C} \mathrm{NMR}\left(100 \mathrm{MHz}, \mathrm{CDCl}_{3}\right): \delta 66.2,68.6,69.5,85.5(\mathrm{Fc}), 122.4$, 123.9, 126.7, 127.0, 129.0, 133.2, 145.4, 147.5 (Ar). Anal. Calcd for $\mathrm{C}_{28} \mathrm{H}_{23} \mathrm{FeN}$ : C, 78.33; H, 5.40; N, 3.26. Found: C, 78.56; H, 5.29; N, 3.31.

Preparation of $\mathbf{1 b}$. 4,4'-(Dibromo)triphenylamine (353 $\mathrm{mg}, 0.88 \mathrm{mmol}$ ), ferrocenylboronic acid (483 mg, $2.00 \mathrm{mmol}$ ), $\mathrm{K}_{3} \mathrm{PO}_{4}$ (558 mg, $2.60 \mathrm{mmol}$ ), $\mathrm{Pd}(\mathrm{OAc})_{2}$ (4 mg, $0.018 \mathrm{mmol}$ ), and 2-(dicyclohexylphosphino)biphenyl (12 mg, $0.035 \mathrm{mmol})$ were suspended in $6 \mathrm{~mL}$ of toluene. The resulting reaction mixture was stirred at $110{ }^{\circ} \mathrm{C}$ under nitrogen atmosphere for $48 \mathrm{~h}$. After the reaction mixture was cooled to ambient temperature, the crude product was purified by column chromatography (eluent: dichloromethane/petroleum ether 1:4 (v/v)). After recrystallization from methanol, the product was obtained as yellow solid. Yield: $216 \mathrm{mg}(40 \%) .{ }^{1} \mathrm{H}$ NMR (400 MHz, $\left.\mathrm{CDCl}_{3}\right): \delta 4.05$ (s, 10H, Fc-H), 4.26 (s, 4H, Fc-H), 4.56 (s, 4H, Fc-H), 7.00 (d, $J=4 \mathrm{~Hz}, 4 \mathrm{H}, \operatorname{Ar}-\mathrm{H}), 7.10(\mathrm{~d}, J=4 \mathrm{~Hz}, 2 \mathrm{H}, \operatorname{Ar}-\mathrm{H}), 7.22(\mathrm{~d}, J=8 \mathrm{~Hz}, 2 \mathrm{H}$, Ar-H), 7.32 (d, $J=8 \mathrm{~Hz}, 4 \mathrm{H}, \mathrm{Ar}-\mathrm{H}), 7.42$ (d, $J=8 \mathrm{~Hz}, 1 \mathrm{H}, \mathrm{Ar}-\mathrm{H}) .{ }^{13} \mathrm{C}$ NMR $(100$ $\left.\mathrm{MHz}, \mathrm{CDCl}_{3}\right): \delta 66.1,68.6,69.4,85.4(\mathrm{Fc}), 122.3,123.7,126.6,127.0,128.9,133.1$, 145.3, 147.4 (Ar). Anal. Calcd for $\mathrm{C}_{38} \mathrm{H}_{31} \mathrm{Fe}_{2} \mathrm{~N}$ : C, 74.41; H, 5.09; N, 2.28. Found: C, 74.17; H, 4.98; N, 2.30 .

Preparation of 1c. 2c (108 mg, $0.20 \mathrm{mmol})$, ferrocenylboronic acid (54 mg, 0.24 $\mathrm{mmol}), \mathrm{K}_{2} \mathrm{CO}_{3}(82 \mathrm{mg}, 0.60 \mathrm{mmol}), \operatorname{Pd}(\mathrm{OAc})_{2}(0.9 \mathrm{mg}, 0.004 \mathrm{mmol})$, and 1,1'-bis(diphenylphosphino)ferrocene $(6 \mathrm{mg}, 0.01 \mathrm{mmol}$ ) were suspended in $5 \mathrm{~mL}$ of toluene. The resulting reaction mixture was stirred at $100{ }^{\circ} \mathrm{C}$ under nitrogen atmosphere for $48 \mathrm{~h}$. After the reaction mixture was cooled to ambient temperature, the crude product was purified by column chromatography (eluent: petroleum ether/ethyl acetate 32:3 (v/v)). After recrystallization from methanol, the product was obtained as yellow solid 78mg. Yield: $61 \%$. ${ }^{1} \mathrm{H}$ NMR (400 MHz, $\mathrm{CDCl}_{3}$ ): $\delta 3.78$ (s, 6H, OMe-H), 4.04 (s, 5H, Fc-H), 4.26 (s, 2H, Fc-H ), 4.55 (s, 2H, Fc-H ), 6.79-6.85 (m, 6H, Ar-H), 6.91-6.97 (m, 5H, Ar-H), 7.02-7.07 (m, 6H, Ar-H), 7.19-7.21 (d, $J=8$ 
$\mathrm{Hz}, 2 \mathrm{H}, \mathrm{Ar}-\mathrm{H}), 7.29-7.31(\mathrm{~d}, J=8 \mathrm{~Hz}, 2 \mathrm{H}, \mathrm{Ar}-\mathrm{H}) .{ }^{13} \mathrm{C} \mathrm{NMR}\left(100 \mathrm{MHz}, \mathrm{CDCl}_{3}\right): \delta$ 55.5 (OMe), 66.2, 68.6, $69.5(\mathrm{Fc}), 85.8,114.5,121.8,122.1,123.0,125.8,126.7$, $128.9,132.5,140.6,141.1,144.2,145.7,147.7,155.3$ (Ar). Anal. Calcd for $\mathrm{C}_{42} \mathrm{H}_{36} \mathrm{FeN}_{2} \mathrm{O}_{2}$ : C, 76.83; H, 5.53; N, 4.27;. Found: C, 76.97; H, 5.48; N, 4.18.

Preparation of bis(4-methoxylphenyl)aminoferrocene, $\mathbf{l d}$. $N$-Ferrocenyl-4-methoxyaniline $(87 \mathrm{mg}, 0.28 \mathrm{mmol})$, 4-bromoanisole $(0.07 \mathrm{ml}, 0.57$ mmol), $t$-BuONa (81 mg, $0.84 \mathrm{mmol}), \mathrm{Pd}_{2}(\mathrm{dba})_{3}(10 \mathrm{mg}, 0.01 \mathrm{mmol})$, and BINAP (7 $\mathrm{mg}, 0.01 \mathrm{mmol}$ ) were suspended in $4 \mathrm{~mL}$ of toluene. The resulting reaction mixture was stirred at $100{ }^{\circ} \mathrm{C}$ for under nitrogen atmosphere $60 \mathrm{~h}$. After the reaction mixture was cooled to ambient temperature, the crude product was purified by column chromatography (eluent: petroleum ether/ethyl acetate 300:1 (v/v)). The pure product was obtained as yellow solid. Yield: $60 \mathrm{mg}(52 \%) .{ }^{1} \mathrm{H}$ NMR (400 $\left.\mathrm{MHz}, \mathrm{CDCl}_{3}\right): \delta$ 3.79 (s, 5H, Fc-H), 3.88 (s, 2H, Fc-H), 3.94 (s, 2H, Fc-H), 4.17 (s, 6H, OMe-H), 6.83-6.85 (d, $J=8 \mathrm{~Hz}, 4 \mathrm{H}, \mathrm{Ar}-\mathrm{H}), 7.20-7.22(\mathrm{~d}, J=8 \mathrm{~Hz}, 4 \mathrm{H}, \mathrm{Ar}-\mathrm{H}) .{ }^{13} \mathrm{C}$ NMR $(100$ $\mathrm{MHz}, \mathrm{CDCl}_{3}$ ): $\delta 55.5$ (OMe), 58.1, 63.4, $68.63(\mathrm{Fc}), 109.0,114.2,125.9,140.7,155.3$ (Ar). Anal. Calcd for $\mathrm{C}_{24} \mathrm{H}_{23} \mathrm{FeNO}_{2}: \mathrm{C}, 69.75 ; \mathrm{H}, 5.61 ; \mathrm{N}, 3.39$. Found: C, 69.58; H, $5.43 ; \mathrm{N}, 3.43$.

Preparation of 1e. 2e (163 mg, $0.40 \mathrm{mmol})$, 4-bromoanisole $(0.09 \mathrm{ml}, 0.80$ mmol), $t$-BuONa (115 mg, $1.20 \mathrm{mmol}), \mathrm{Pd}_{2}(\mathrm{dba})_{3}(18 \mathrm{mg}, 0.02 \mathrm{mmol})$, and BINAP (12 $\mathrm{mg}, 0.02 \mathrm{mmol}$ ) were suspended in $5 \mathrm{~mL}$ of toluene. The resulting reaction mixture was stirred at $100{ }^{\circ} \mathrm{C}$ under nitrogen atmosphere for $50 \mathrm{~h}$. After the reaction mixture was cooled to ambient temperature, the crude product was purified by column chromatography (eluent: petroleum ether/ethyl acetate 100:1 (v/v)). After recrystallization from methanol, the product was obtained as yellow solid. Yield: 90 mg (45\%). ${ }^{1} \mathrm{H}$ NMR (400 MHz, $\mathrm{CDCl}_{3}$ ): $\delta 3.82$ (s, 3H, OMe-H), 3.96 (s, 4H, Fc-H), 4.14 (s, 5H, Fc-H), 6.89-6.97 (m, 6H, Ar-H), 7.04-7.11 (m, 6H, Ar-H), 7.18-7.23 (m, 6H, Ar-H). $\left.{ }^{13} \mathrm{C} \mathrm{NMR} \mathrm{(100} \mathrm{MHz,} \mathrm{CDCl}_{3}\right): \delta 55.5(\mathrm{OMe}), 59.4,63.7,68.7(\mathrm{Fc}), 107.9$, $114.4,121.9,122.4,123.2,125.3,127.9,128.9,140.2,141.0,143.3,147.7,156.3$ (Ar). Anal. Calcd for $\mathrm{C}_{35} \mathrm{H}_{30} \mathrm{FeN}_{2} \mathrm{O}$ : C, 76.37; H, 5.49; N, 5.09. Found: C, 76.11; H, 5.44; N, 5.07 .

Preparation of $\mathbf{1 f}$. Compound $\mathbf{2 f}$ (94 $\mathrm{mg}, 0.15 \mathrm{mmol})$, 4-bromoanisole $(0.08 \mathrm{ml}$, $0.60 \mathrm{mmol}), t$-BuONa (43 mg, $0.45 \mathrm{mmol}), \mathrm{Pd}_{2}(\mathrm{dba})_{3}(6 \mathrm{mg}, 0.006 \mathrm{mmol})$, and BINAP (4 mg, $0.006 \mathrm{mmol}$ ) were suspended in $5 \mathrm{~mL}$ of toluene. The resulting reaction mixture was stirred at $100{ }^{\circ} \mathrm{C}$ under nitrogen atmosphere for $72 \mathrm{~h}$. After the 
reaction mixture was cooled to ambient temperature, the crude product was purified by column chromatography (eluent: petroleum ether/ethyl acetate 40:1 (v/v)). The pure product was obtained as yellow solid. Yield: $58 \mathrm{mg}$ (45\%). ${ }^{1} \mathrm{H}$ NMR (400 MHz, $\mathrm{CDCl}_{3}$ ): $\delta 3.79$ (s, 6H, OMe-H), 3.95 (s, 8H, Fc-H), 4.13 (s, 10H, Fc-H), 6.87-6.89 (d, $J=8 \mathrm{~Hz}, 4 \mathrm{H}, \mathrm{Ar}-\mathrm{H}), 6.95-6.97$ (d, $J=8 \mathrm{~Hz}, 4 \mathrm{H}, \mathrm{Ar}-\mathrm{H}), 7.02-7.10$ (m, 8H, Ar-H), 7.15-7.22 (m, 5H, Ar-H). ${ }^{13} \mathrm{C}$ NMR (100 MHz, $\left.\mathrm{CDCl}_{3}\right): \delta 55.5(\mathrm{OMe}), 59.2,63.7$, 68.7 (Fc), 108.0, 114.4, 121.3, 122.3, 122.7, 124.0, 127.8, 128.8, 140.2, 141.3, 142.9, 148.0, 156.3 (Ar). Anal. Calcd for $\mathrm{C}_{52} \mathrm{H}_{45} \mathrm{Fe}_{2} \mathrm{~N}_{3} \mathrm{O}_{2}$ : C, 72.99; H, 5.30; N, 4.91. Found: C, 72.75; H, 5.41; N, 4.95 .

\section{X-ray Crystallography}

Single crystals of complex 1d suitable for X-ray analysis were grown from a solution in dichloromethane by slow solvent evaporation at room temperature. A selected crystal with approximate dimensions of $0.20 \times 0.10 \times 0.10 \mathrm{~mm}^{3}$ was mounted on a glass fiber for diffraction experiments. Intensity data were collected on a Nonius Kappa CCD diffractometer with Mo K $\alpha$ radiation (0.71073 $\AA$ ) at room temperature. The crystal structure was determined by a combination of direct methods $\left(\right.$ SHELXS-97) ${ }^{20}$ and Fourier difference techniques and refined by full matrix least squares (SHELXL-97) ${ }^{21}$. All non-H atoms were refined anisotropically. The hydrogen atoms were placed in ideal positions and refined as riding atoms. The partial solvent molecules have been omitted. Selected bond distances and angles are given in Table 1. Further crystal data and details of the data collection are summarized in Table S1. Crystallographic data for the structure have been deposited with the Cambridge Crystallographic Data Centre as supplementary publication CCDC 1564068.

\section{Physical Measurements}

${ }^{1} \mathrm{H}$ and ${ }^{13} \mathrm{C}$ NMR spectra (Figures S13 - S30, Supporting Information) were collected on a Varian Mercury Plus 400 spectrometer $(400 \mathrm{MHz}) .{ }^{1} \mathrm{H}$ and ${ }^{13} \mathrm{C}$ NMR chemical shifts are given relative to $\mathrm{Si}\left(\mathrm{CH}_{3}\right)_{4}$. Elemental analyses $(\mathrm{C}, \mathrm{H}, \mathrm{N})$ were performed with a Vario ElIII Chnso instrument. The electrochemical measurements were performed on a $\mathrm{CHI} 660 \mathrm{C}$ potentiostat. A three-electrode single-compartment 
cell was used for the solution of complexes and supporting electrolyte in dry $\mathrm{CH}_{2} \mathrm{Cl}_{2}$. The solution was deaerated by bubbling with dry argon on a frit for about $10 \mathrm{~min}$ before the measurement. The analyte (complex, ligand) and electrolyte $\left(n-\mathrm{Bu}_{4} \mathrm{NPF}_{6}\right)$ concentrations were typically $10^{-3}$ and $10^{-1} \mathrm{~mol} \mathrm{dm}^{-3}$, respectively. A pre-polished $500-\mu \mathrm{m}$ diameter platinum disk working electrode, a platinum wire counter electrode, and an Ag wire pseudoreference electrode were used. Ferrocene was used as the internal potential reference. Spectroelectrochemical experiments at room temperature were performed with an airtight optically transparent thin-layer electrochemical (OTTLE) cell (optical path length of ca. $200 \mu \mathrm{m}$ ) equipped with a Pt minigrid working electrode and $\mathrm{CaF}_{2}$ windows. ${ }^{22}$ The cell was positioned in the sample compartment of a Shimadzu UV-3600 UV-vis-NIR spectrophotometer. The controlled-potential electrolyses were carried out with a $\mathrm{CHI} 660 \mathrm{C}$ potentiostat. The concentration of analyte samples was ca $2 \times 10^{-3} \mathrm{~mol} \mathrm{dm}^{-3}$. Dry $3 \times 10^{-1} \mathrm{M} n-\mathrm{Bu}_{4} \mathrm{NPF}_{6}$ was used as the supporting electrolyte.

\section{Computational Details}

DFT calculations were performed with the Gaussian $09 \operatorname{program}^{23}$, at the ${\mathrm{B} 3 \mathrm{LYP}^{24} \text { or CAM-B3LYP }}^{25} / 6-31 \mathrm{G}^{* 26}$ level of theory. The basis set employed was 6-31G* (Lanl2DZ for Fe atom). Geometry optimization was performed without any symmetry constraints. Electronic transitions were calculated by the time-dependent DFT (TD-DFT) method. The MO contributions were generated using the Multiwfn package and plotted using GaussView 5.0. The solvation effects in dichloromethane are included for a part of the calculations with the conductor-like polarizable continuum model (CPCM). ${ }^{27}$

\section{Acknowledgements}

The authors gratefully acknowledge financial support from the National Natural Science Foundation of China (21472059), the Overseas Talent Plan 111 Project 
B17019, the self-determined research funds of CCNU from the colleges' basic research and the operation of MOE (CCNU14A05009, CCNU14F01003).

\section{Author Information}

${ }^{a}$ Key Laboratory of Pesticide \& Chemical Biology, Ministry of Education, College of Chemistry, Central China Normal University, 152 Luoyu Road, Wuhan, Hubei 430079 (China)

E-mail: chshliu@mail.ccnu.edu.cn (S.H.Liu); f.hartl@reading.ac.uk (F.Hartl)

\section{Notes}

The authors declare no competing financial interest.

$\dagger$ Electronic supplementary information (ESI) available: Crystallographic information, Electrochemistry, UV-vis-NIR spectroelectrochemistry, DFT/TD-DFT, and NMR data.

\section{References and Notes}

1 (a) A. Hildebrandt and H. Lang, Organometallics, 2013, 32, 5640; (b) M. Lohan, F. Justaud, T. Roisnel, P. Ecorchard, H. Lang, and C. Lapinte, Organometallics, 2010, 29, 4804; (c) U. Pfaff, A. Hildebrandt, M. Korb, D. Schaarschmidt, M. Rosenkranz, A. Popov and H. Lang, Organometallics, 2015, 34, 2826; (d) D. Miesel, A. Hildebrandt, M. Korb, D. A. Wild, P. J. Low and H. Lang, Chem.- Eur. J., 2015, 21, 11545; (e) A. Hildebrandt and H. Lang, Dalton Trans., 2011, 40, 11831; (f) S. Chandra, C. Gäbler, C. Schliebe, H. Lang and D. Bahadur, New J. Chem., 2016, 40, 9046; (g) M. S. Inkpen, S. Scheerer, M. Linseis, A. J. P. White, R. F. Winter, T. Albrecht and N. J. Long, Nat. Chem., 2016, 8, 825.

2 (a) J. P. Lewtak, M. Landman, I. Fernández and J. C. Swarts, Inorg. Chem., 2016, 55, 2584; (b) F. Barrière, N. Camire, W. E. Geiger, U. T. Mueller-Westerhoff and R. Sanders, J. Am. Chem. Soc., 2002, 124, 7262; (c) J. Casado, S. R. González, M. C. R. Delgado, M. M. Oliva, J. T. L. Navarrete, R. Caballero, P. Cruz and F. Langa, Chem. 
Eur. J., 2009, 15, 2548; (d) A. K. Diallo, J.-C. Daran, F. Varret, J. Ruiz and D. Astruc, Angew. Chem. Int. Ed., 2009, 48, 3141; (e) S. J. Dammer, P. V. Solntsev, J. R. Sabin and V. N. Nemykin, Inorg. Chem., 2013, 52, 9496; (f) R. Breuer and M. Schmittel, Organometallics, 2012, 31, 1870; (g) W. R. Goetsch, P. V. Solntsev, C. V. Stappen, A. A. Purchel, S. V. Dudkin and V. N. Nemykin, Organometallics, 2014, 33, 145; (h) A. Hildebrandt, K. A. Khalyfeh, J. F. Nawroth and R. Jordan, Organometallics, 2016, 35, 3713 ; (i) K. Ventura, M. B. Smith, J. R. Prat, L. E. Echegoyen and D. Villagrán, J. Chem. Educ., 2017, 94, 526.

3 (a) G. Zhou, M. Baumgarten and K. Müllen, J. Am. Chem. Soc., 2007, 129, 12211; (b) C. Lambert, C. Risko, V. Coropceanu, J. Schelter, S. Amthor, N. E. Gruhn, J. C. Durivage and J.-L. Brédas, J. Am. Chem. Soc., 2005, 127, 8508; (c) K. Lancaster, S. A. Odom, S. C. Jones, S. Thayumanavan, S. R. Marder, J.-L. Brédas, V. Coropceanu and S. Barlow, J. Am. Chem. Soc., 2009, 131, 1717; (d) E. T. Seo, R. F. Nelson, J. M. Fritsch, L. S. Marcoux, D. W. Leedy and R. N. Adams, J. Am. Chem. Soc., 1966, 88, 3498; (e) H.-C. Cheng, K. Y. Chiu, S. H. Lu, C.-C. Chen, Y. W. Lee, T.-F. Yang, M. Y. Kuo, P. P.-Y. Chen and Y. O. Su, J. Phys. Chem. A., 2015, 119, 1933; (f) J. Hankache and O. S. Wenger, Chem Rev., 2011, 111, 5138.

4 (a) J. Zhang, S.-Z. Guo, Y.-B. Dong, L. Rao, J. Yin, G.-A. Yu, F. Hartl and S.-H. Liu, Inorg. Chem., 2017, 56, 1001; (b) M. Parthey, K. B. Vincent, M. Renz, P. A. Schauer, D. S. Yufit, J. A. K. Howard, M. Kaupp and P. J. Low, Inorg. Chem., 2014, 53, 1544; (c) A. Heckmann and C. Lambert, Angew. Chem. Int. Ed., 2012, 51, 326; (d) C. Lambert, G. Nöll and J. Schelter, Nat Mater., 2002, 1, 69; (e) C.-J. Yao, Y.-W. Zhong and J.-N. Yao, Inorg. Chem., 2013, 52, 10000; (f) S. Barlow, C. Risko, S. A. Odom, S. Zheng, V. Coropceanu, L. Beverina, J.-L. Brédas and S. R. Marder, J. Am. Chem. Soc., 2012, 134, 10146; (g) J. Zhang, G.-T. Liu, X.-Y. Wang, G.-A. Yu, J. Yin and S.-H. Liu, Dyes Pigments, 2017, 143, 416.

5 (a) M. A. Fox , R. L. Roberts, T. E. Baines, B. Le Guennic, J.-F. Halet, F. Hartl, D. S. Yufit, D. Albesa-Jové, J. A. K. Howard and P. J. Low, J. Am. Chem. Soc., 2008, 130, 3566; (b) J. Zhang, Z. Chen, L. Yang, F.-F. Pan, G.-A. Yu, J. Yin and S.-H. Liu, Sci. Rep., 2016, 6, 36310; (c) P. J. Low, Coord. Chem. Rev., 2013, 257, 1507; (d) L.-B. 
Gao, J. Kan, Y. Fan, L.-Y. Zhang, S.-H. Liu and Z.-N. Chen, Inorg. Chem., 2007, 46, 5651; (e) P. J. Low, Dalton Trans., 2005, 2821; (f) M. Akita and T. Koike, Dalton Trans., 2008, 3523; (g) J. Zhang, M.-X. Zhang, C.-F. Sun, M. Xu, F. Hartl, J. Yin, G.-A. Yu, L. Rao and S.-H. Liu, Organometallics, 2015, 34, 3967; (h) J.-W. Ying, I. P.-C. Liu, B. Xi, Y. Song, C. Campana, J.-L. Zuo and T. Ren, Angew. Chem. Int. Ed., $2010,49,954$.

6 (a) S. Roué, H. Sahnoune, L. Toupet, J.-F. Halet and C. Lapinte, Organometallics, 2016, 35, 2057; (b) Y. Li, O. Blacque, T. Fox, S. Luber, W. Polit, R. F. Winter, K. Venkatesana and H. Berke, Dalton Trans., 2016, 45, 5783; (c) Y.-W. Zhong, Z.-L. Gong, J.-Y. Shao and J.-N. Yao, Coord. Chem. Rev., 2016, 312, 22; (d) L.-B. Gao, L.-Y. Zhang, L.-X. Shi and Z.-N. Chen, Organometallics, 2005, 24, 1678; (e) H. Lei, X. Xiao, M. Meng, T. Cheng, Y. Shu, Y. N. Tan and C. Y. Liu, Inorg. Chimi. Acta., 2015, 424, 63; (f) Z. Cao, B. Xi, D. S. Jodoin, L. Zhang, S. P. Cummings, Y. Gao, S. F. Tyler, P. E. Fanwick, R. J. Crutchley and T. Ren, J. Am. Chem. Soc., 2014, 136, 12174.

7 (a) G. Grelaud, O. Cador, T. Roisnel, G. Argouarch, M. P. Cifuentes, M. G. Humphrey and F. Paul, Organometallics, 2012, 31, 1635; (b) B.-B. Cui, J.-H. Tang, J.-N. Yao and Y.-W. Zhong, Angew. Chem. Int. Ed., 2015, 54, 9192; (c) D. Fink, B. Weibert and R. F. Winter, Chem. Commun., 2016, 52, 6103; (d) W. Polit, T. Exner, E. Wuttke and R. F. Winter, BioInorg. React. Mech., 2012, 8, 85; (e) J.-H. Tang, J.-Y. Shao,Y.-Q. He, S.-H. Wu, J.-N. Yao and Y.-W. Zhong, Chem. -Eur. J., 2016, 22, 10341; (f) H.-C. Cheng, K. Y..Chiu, S. H. Lu, C.-C. Chen, Y. W. Lee, T.-F. Yang, M.Y. Kuo, P. P.-Y.Chen and Y. O. Su, J. Phys. Chem. A., 2015, 119, 1933; (g) K. Onitsuka, N. Ohara, F. Takei and S. Takahashi, Dalton Trans., 2006, 3693; (h) G. Grelaud, M. P. Cifuentes, T. Schwich, G. Argouarch, S. Petrie, R. Stranger, F. Paul and M. G. Humphrey, Eur. J. Inorg. Chem., 2012, 65; (i) K. Onitsuka, N. Ohara, F. Takei and S. Takahashi, Organometallics, 2008, 27, 25.

8 (a) J. A. Lee, B. N. Williams, K. R. Ogilby, K. L. Miller and P. L. Diaconescu, J. Organomet. Chem., 2011, 696, 4090; (b) Y.-W. Chang, M.-J. Huang, C.-C. Lai, C.-C. Chang, M.-P. Huang, C.-Y. Liao and C.-H. Cheng, Chem. Commun., 2016, 52, 14294; 
(c) A. Mendiratta, S. Barlow, M. W. Day and S. R. Marder, Organometallics, 1999, 18, 454. (d) S. Sethi, P. K. Das and N. Behera. J. Organomet. Chem., 2016, 824, 140. (e) C. C. Chiang, H. C. Chen, C. S. Lee, M. K. Leung, K. R. Lin and K. H. Hsieh. Chem. Mat., 2007, 20, 540. (f) Y. Shirota. J. Mater. Chem., 2000, $10,1$.

9 (a) Ö. Salih, S. Ellen, L. Annika and B. Carsten, Synthesis, 2007, 3, 389; (b) A. Houlton, P. T. Bishop, R. M. G. Roberts and J. S. M. Herberhold, J. Organomet. Chem., 1989, 364, 381; (c) W. E. Britton, R. Kashyap, M. El-Hashash, M. El-Kady and M. Herberhold, Organometallics, 1986, 5, 1029; (d) S.-X. Lu, V. V. Strelets, M. F. Ryan, W. J. Pietro and A. B. P. Lever, Inorg. Chem., 1996, 35, 1013.

10 W. Polit, P. Mücke, E. Wuttke, T. Exner and R. F. Winter, Organometallics, 2013, 32, 5461 .

11 D. Lionetti, A. J. Medvecz, V. Ugrinova, M. Quiroz-Guzman, B. C. Noll and S. N. Brown, Inorg. Chem., 2010, 49, 4687.

12 H. Murata and P. M. Lahti, J. Org. Chem., 2007, 72, 4974.

13 M. Parthey, K. B. Vincent, M. Renz, P. A. Schauer, D. S. Yufit, J. A. K. Howard, M. Kaupp and P. J. Low, Inorg. Chem., 2014, 53, 1544.

14 D. E. Richardson and H. Taube, Inorg. Chem., 1981, 20, 1278.

15 The reliability of the B3LYP and CAM-B3LYP methods employed for the TD DFT calculations of the low-lying electronic transitions exhibited by the studied singly oxidized TAP-ferrocenium and DPA-ferrocenium complexes, $[\mathbf{1 a}]^{+}-[\mathbf{1 e}]^{+}$(Table 4), was tested for phenylferrocenium, $[\mathrm{Ph}-\mathrm{Fc}]^{+}$, as the suited reference complex lacking the NIR absorption band. The results are presented in the Supporting Information, in a dedicated section preceding the depicted set of experimental NMR spectra (see Figures S13-S17 and the corresponding explanatory Figure captions).

16 L.-Q. Shi, C. He, D.-F. Zhu, Q.-G He, Y. Li, Y. Chen, Y.-X. Sun, Y.-Y. Fu, D. Wen, H.-M. Cao and J.-G. Cheng, J. Mater. Chem., 2012, 22, 11629.

17 K. Zhang, L. Wang, Y.-L. Liang, S.-Q. Yang, J. Liang, F.-Y. Cheng and J. Chen, Synth. Met., 2012, 162, 490.

18 C. A. Fleckenstein and H. Plenio, Organometallics, 2007, 26, 2758.

19 D. C. D. Butler and C. J. Richards, Organometallics, 2002, 21, 5433. 
20 G. M. Sheldrick, SHELXS-97, a Program for Crystal Structure Solution; University of Göttingen: Göttingen, Germany, 1997.

21 G. M. Sheldrick, SHELXL-97, a Program for Crystal Structure Refinement; University of Göttingen, Göttingen, Germany, 1997.

22 M. Krejčík, M. Daněk and F. Hart1, J. Electroanal. Chem. Interfacial Electrochem., 1991, 317, 179.

23 Gaussian 09, Revision D.01, M. J. Frisch, G. W. Trucks, H. B. Schlegel, G. E. Scuseria, M. A. Robb, J. R. Cheeseman, G. Scalmani, V. Barone, B. Mennucci, G. A. Petersson, H. Nakatsuji, M. Caricato, X. Li, H. P. Hratchian, A. F. Izmaylov, J. Bloino, G. Zheng, J. L. Sonnenberg, M. Hada, M. Ehara, K. Toyota, R. Fukuda, J. Hasegawa, M. Ishida, T. Nakajima, Y. Honda, O. Kitao, H. Nakai, T. Vreven, J. A. Montgomery, Jr., J. E. Peralta, F. Ogliaro, M. Bearpark, J. J. Heyd, E. Brothers, K. N. Kudin, V. N. Staroverov, R. Kobayashi, J. Normand, K. Raghavachari, A. Rendell, J. C. Burant, S. S. Iyengar, J. Tomasi, M. Cossi, N. Rega, J. M. Millam, M. Klene, J. E. Knox, J. B. Cross, V. Bakken, C. Adamo, J. Jaramillo, R. Gomperts, R. E. Stratmann, O. Yazyev, A. J. Austin, R. Cammi, C. Pomelli, J. W. Ochterski, R. L. Martin, K. Morokuma, V. G. Zakrzewski, G. A. Voth, P. Salvador, J. J. Dannenberg, S. Dapprich, A. D. Daniels, Ö. Farkas, J. B. Foresman, J. V. Ortiz, J. Cioslowski, and D. J. Fox, Gaussian, Inc., Wallingford CT, 2009.

24 (a) A. D. Becke, J. Chem. Phys., 1993, 98, 5648; (b) C. Lee, W. Yang and R. G. Parr, Phys. Rev. B., 1988, 37, 785.

25. T. Yanai, D. P.Tew and N. C. Handy, Chem. Phys. Lett., 2004, 393, 51-57.

26 T. H. Dunning, P. J. Hay in Modern Theoretical Chemistry, Vol. 3 (Ed.: H. F. Schaefer), Plenum, New York, 1976, p.1.

27 (a) V. Barone and M. Cossi, J. Phys. Chem. A., 1998, 102, 1995; (b) M. Cossi, N. Rega, G. Scalmani and V. Barone, J. Comput. Chem., 2003, 24, 669. 


\section{TOC and Graphical Abstract}

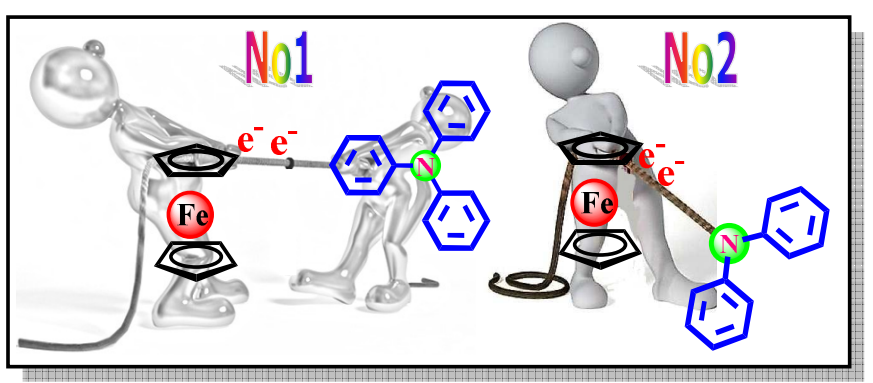

The multistep anodic behavior of two series of nonlinear (di)aminophenylferrocene, and diphenylaminoferrocene complexes is reported. The influence of the integration of diverse redox-active components on the sequential oxidation of these complexes has been explored. The first anodic steps all take place uniformly on the ferrocenyl units, followed by oxidation of the triphenylamine and $\mathrm{Cp}$-diphenylamine moieties. The assignment of the anodic steps has been supported by DFT calculations.
Ming-Xing Zhang, Jing Zhang, Jun Yin, František Hartl, * Sheng Hua $\mathrm{Liu}^{*}$

Page No. - Page No.

Title: Anodic Electrochemistry of Mono- and Dinuclear Aminophenylferrocene and Diphenylaminoferrocene Complexes 


\title{
Anodic Electrochemistry of Mono- and Dinuclear Aminophenylferrocene and Diphenylaminoferrocene Complexes
}

\author{
Ming-Xing Zhang, ${ }^{\dagger, \S}$ Jing Zhang, ${ }^{\dagger}, \pi, \S$ Jun Yin, ${ }^{\dagger}$ František Hartl, ${ }^{*}{ }^{\star}$ Sheng-Hua Liu* ${ }^{*}$ \\ ${ }^{\dagger}$ Key Laboratory of Pesticide and Chemical Biology, Ministry of Education, College \\ of Chemistry, Central China Normal University, Wuhan 430079, P.R. China \\ " College of Chemistry, The Hong Kong University of Science and Technology, Clear \\ Water Bay, Kowloon, Hong Kong \\ ${ }^{\ddagger}$ Department of Chemistry, University of Reading, Whiteknights, Reading RG6 6AD, \\ $U K$ \\ ${ }^{\S}$ These authors contributed equally to this work.
}


Table S1. Crystal data and parameters of data collection and refinement for complex 1d.

\begin{tabular}{|c|c|}
\hline Complex & 1d \\
\hline Formula & $\mathrm{C}_{24} \mathrm{H}_{23} \mathrm{FeNO}_{2}$ \\
\hline Formula weight & 413.28 \\
\hline Temperature (K) & $296(2)$ \\
\hline Crystal system & Monoclinic \\
\hline Space group & $P 2(1) / c$ \\
\hline$a(\AA)$ & $17.7696(18)$ \\
\hline$b(\AA)$ & $9.6825(10)$ \\
\hline$c(\AA)$ & $22.947(2)$ \\
\hline$\alpha\left(^{\circ}\right)$ & 90 \\
\hline$\beta\left(^{\circ}\right)$ & $92.595(2)$ \\
\hline$\gamma\left({ }^{\circ}\right)$ & 90 \\
\hline$V\left(\AA^{3}\right)$ & $3944.1(7)$ \\
\hline$Z$ & 8 \\
\hline Density (calculated) $\left(\mathrm{Mg} / \mathrm{m}^{3}\right)$ & 1.392 \\
\hline Absorption coefficient $\left(\mathrm{mm}^{-1}\right)$ & 0.784 \\
\hline$F(000)$ & 1728 \\
\hline Crystal size $\left(\mathrm{mm}^{3}\right)$ & $0.20 \times 0.10 \times 0.10$ \\
\hline Theta range for data collection $\left(^{\circ}\right)$ & 1.78 to 27.45 \\
\hline Index ranges & $-23 \leq h \leq 23,-12 \leq k \leq 12,-29 \leq l \leq 29$ \\
\hline Reflections collected & 32836 \\
\hline Independent reflections & $8967[R($ int $)=0.0562]$ \\
\hline Max. and min. transmission & 0.9257 and 0.9118 \\
\hline Data / restraints / parameters & $8967 / 0$ / 510 \\
\hline Goodness-of-fit on $F^{2}$ & 0.997 \\
\hline Final $R$ indices $[I>2 \sigma(I)]$ & $R 1=0.0443, w R 2=0.1093$ \\
\hline$R$ indices (all data) & $R 1=0.0826, w R 2=0.1266$ \\
\hline Largest diff. peak and hole $\left(\mathrm{e}^{-3}\right)$ & 0.279 and -0.336 \\
\hline
\end{tabular}


Table S2. Bond lengths $[\AA]$ and angles [deg] for complex 1d.

\begin{tabular}{|c|c|c|c|}
\hline \multicolumn{4}{|c|}{ Bond lengths $[\AA]]$} \\
\hline $\mathrm{Fe} 1-\mathrm{C} 3$ & $2.028(3)$ & $\mathrm{C} 7-\mathrm{C} 8$ & $1.410(4)$ \\
\hline $\mathrm{Fe} 1-\mathrm{C} 2$ & $2.034(2)$ & $\mathrm{C} 11-\mathrm{C} 16$ & $1.369(4)$ \\
\hline $\mathrm{Fe} 1-\mathrm{C} 10$ & $2.036(3)$ & $\mathrm{C} 11-\mathrm{C} 12$ & $1.383(3)$ \\
\hline $\mathrm{Fe} 1-\mathrm{C} 4$ & $2.038(3)$ & $\mathrm{O} 1-\mathrm{C} 14$ & $1.372(3)$ \\
\hline $\mathrm{Fe} 1-\mathrm{C} 9$ & $2.038(3)$ & $\mathrm{O} 1-\mathrm{C} 17$ & $1.408(4)$ \\
\hline $\mathrm{Fe} 1-\mathrm{C} 7$ & $2.040(3)$ & $\mathrm{C} 19-\mathrm{C} 20$ & $1.369(4)$ \\
\hline $\mathrm{Fe} 1-\mathrm{C} 6$ & $2.040(3)$ & $\mathrm{C} 2-\mathrm{C} 3$ & $1.416(4)$ \\
\hline $\mathrm{Fe} 1-\mathrm{C} 8$ & $2.044(3)$ & $\mathrm{C} 21-\mathrm{C} 22$ & $1.382(4)$ \\
\hline $\mathrm{Fe} 1-\mathrm{C} 5$ & $2.061(3)$ & $\mathrm{C} 21-\mathrm{C} 20$ & $1.386(4)$ \\
\hline $\mathrm{Fe} 1-\mathrm{C} 1$ & $2.072(2)$ & $\mathrm{C} 9-\mathrm{C} 8$ & $1.403(4)$ \\
\hline $\mathrm{N} 1-\mathrm{C} 1$ & $1.411(3)$ & $\mathrm{C} 9-\mathrm{C} 10$ & $1.408(4)$ \\
\hline $\mathrm{N} 1-\mathrm{C} 18$ & $1.425(3)$ & $\mathrm{C} 10-\mathrm{C} 6$ & $1.415(4)$ \\
\hline $\mathrm{N} 1-\mathrm{C} 11$ & $1.439(3)$ & $\mathrm{C} 13-\mathrm{C} 12$ & $1.376(4)$ \\
\hline $\mathrm{O} 2-\mathrm{C} 21$ & $1.373(3)$ & $\mathrm{C} 13-\mathrm{C} 14$ & $1.378(4)$ \\
\hline $\mathrm{O} 2-\mathrm{C} 24$ & $1.421(3)$ & $\mathrm{C} 22-\mathrm{C} 23$ & $1.383(4)$ \\
\hline $\mathrm{C} 18-\mathrm{C} 23$ & $1.387(3)$ & $\mathrm{C} 16-\mathrm{C} 15$ & $1.387(4)$ \\
\hline $\mathrm{C} 18-\mathrm{C} 19$ & $1.394(3)$ & $\mathrm{C} 15-\mathrm{C} 14$ & $1.379(4)$ \\
\hline $\mathrm{C} 1-\mathrm{C} 2$ & $1.422(4)$ & $\mathrm{C} 4-\mathrm{C} 3$ & $1.405(4)$ \\
\hline $\mathrm{C} 1-\mathrm{C} 5$ & $1.425(4)$ & $\mathrm{C} 4-\mathrm{C} 5$ & $1.421(4)$ \\
\hline $\mathrm{C} 7-\mathrm{C} 6$ & $1.403(4)$ & $\mathrm{C} 7-\mathrm{C} 8$ & $1.410(4)$ \\
\hline \multicolumn{4}{|c|}{ Bond angles $[\mathrm{deg}]$} \\
\hline $\mathrm{C} 3-\mathrm{Fe} 1-\mathrm{C} 2$ & $40.79(10)$ & $\mathrm{C} 8-\mathrm{Fe} 1-\mathrm{C} 1$ & $152.56(11)$ \\
\hline $\mathrm{C} 3-\mathrm{Fe} 1-\mathrm{C} 10$ & $153.66(13)$ & $\mathrm{C} 5-\mathrm{Fe} 1-\mathrm{C} 1$ & $40.34(10)$ \\
\hline $\mathrm{C} 2-\mathrm{Fe} 1-\mathrm{C} 10$ & $164.75(12)$ & $\mathrm{C} 1-\mathrm{N} 1-\mathrm{C} 18$ & $124.0(2)$ \\
\hline $\mathrm{C} 3-\mathrm{Fe} 1-\mathrm{C} 4$ & $40.45(12)$ & $\mathrm{C} 1-\mathrm{N} 1-\mathrm{C} 11$ & $114.3(2)$ \\
\hline $\mathrm{C} 2-\mathrm{Fe} 1-\mathrm{C} 4$ & $68.27(11)$ & $\mathrm{C} 18-\mathrm{N} 1-\mathrm{C} 11$ & $117.4(2)$ \\
\hline $\mathrm{C} 10-\mathrm{Fe} 1-\mathrm{C} 4$ & $120.30(13)$ & $\mathrm{C} 21-\mathrm{O} 2-\mathrm{C} 24$ & $117.2(2)$ \\
\hline $\mathrm{C} 3-\mathrm{Fe} 1-\mathrm{C} 9$ & $119.25(12)$ & $\mathrm{C} 23-\mathrm{C} 18-\mathrm{C} 19$ & $117.4(2)$ \\
\hline $\mathrm{C} 2-\mathrm{Fe} 1-\mathrm{C} 9$ & $152.74(13)$ & $\mathrm{C} 23-\mathrm{C} 18-\mathrm{N} 1$ & $124.1(2)$ \\
\hline
\end{tabular}




\begin{tabular}{|c|c|c|c|}
\hline $\mathrm{C} 10-\mathrm{Fe} 1-\mathrm{C} 9$ & $40.45(13)$ & $\mathrm{C} 19-\mathrm{C} 18-\mathrm{N} 1$ & $118.5(2)$ \\
\hline $\mathrm{C} 4-\mathrm{Fe} 1-\mathrm{C} 9$ & $109.02(12)$ & $\mathrm{N} 1-\mathrm{C} 1-\mathrm{C} 2$ & $123.4(2)$ \\
\hline $\mathrm{C} 3-\mathrm{Fe} 1-\mathrm{C} 7$ & $126.54(12)$ & $\mathrm{N} 1-\mathrm{C} 1-\mathrm{C} 5$ & $129.1(2)$ \\
\hline $\mathrm{C} 2-\mathrm{Fe} 1-\mathrm{C} 7$ & $107.12(11)$ & $\mathrm{C} 2-\mathrm{C} 1-\mathrm{C} 5$ & $107.4(2)$ \\
\hline $\mathrm{C} 10-\mathrm{Fe} 1-\mathrm{C} 7$ & $67.95(12)$ & $\mathrm{N} 1-\mathrm{C} 1-\mathrm{Fe} 1$ & $130.19(17)$ \\
\hline $\mathrm{C} 4-\mathrm{Fe} 1-\mathrm{C} 7$ & $164.45(13)$ & $\mathrm{C} 2-\mathrm{C} 1-\mathrm{Fe} 1$ & $68.32(14)$ \\
\hline $\mathrm{C} 9-\mathrm{Fe} 1-\mathrm{C} 7$ & $67.84(12)$ & $\mathrm{C} 5-\mathrm{C} 1-\mathrm{Fe} 1$ & $69.40(15)$ \\
\hline $\mathrm{C} 3-\mathrm{Fe} 1-\mathrm{C} 6$ & $163.97(12)$ & $\mathrm{C} 6-\mathrm{C} 7-\mathrm{C} 8$ & $108.2(3)$ \\
\hline $\mathrm{C} 2-\mathrm{Fe} 1-\mathrm{C} 6$ & $126.45(11)$ & $\mathrm{C} 6-\mathrm{C} 7-\mathrm{Fe} 1$ & $69.89(16)$ \\
\hline $\mathrm{C} 10-\mathrm{Fe} 1-\mathrm{C} 6$ & $40.64(12)$ & $\mathrm{C} 8-\mathrm{C} 7-\mathrm{Fe} 1$ & $69.96(17)$ \\
\hline $\mathrm{C} 4-\mathrm{Fe} 1-\mathrm{C} 6$ & $154.30(13)$ & $\mathrm{C} 16-\mathrm{C} 11-\mathrm{C} 12$ & $119.5(2)$ \\
\hline $\mathrm{C} 9-\mathrm{Fe} 1-\mathrm{C} 6$ & $68.03(12)$ & $\mathrm{C} 16-\mathrm{C} 11-\mathrm{N} 1$ & $120.4(2)$ \\
\hline $\mathrm{C} 7-\mathrm{Fe} 1-\mathrm{C} 6$ & $40.23(11)$ & $\mathrm{C} 12-\mathrm{C} 11-\mathrm{N} 1$ & $119.9(2)$ \\
\hline $\mathrm{C} 3-\mathrm{Fe} 1-\mathrm{C} 8$ & $107.69(13)$ & $\mathrm{C} 14-\mathrm{O} 1-\mathrm{C} 17$ & $116.8(3)$ \\
\hline $\mathrm{C} 2-\mathrm{Fe} 1-\mathrm{C} 8$ & $118.47(11)$ & $\mathrm{C} 9-\mathrm{C} 10-\mathrm{Fe} 1$ & $69.86(17)$ \\
\hline $\mathrm{C} 10-\mathrm{Fe} 1-\mathrm{C} 8$ & $67.85(12)$ & $\mathrm{C} 6-\mathrm{C} 10-\mathrm{Fe} 1$ & $69.82(16)$ \\
\hline $\mathrm{C} 4-\mathrm{Fe} 1-\mathrm{C} 8$ & $127.47(12)$ & $\mathrm{C} 12-\mathrm{C} 13-\mathrm{C} 14$ & $119.6(2)$ \\
\hline $\mathrm{C} 9-\mathrm{Fe} 1-\mathrm{C} 8$ & $40.20(12)$ & $\mathrm{C} 19-\mathrm{C} 20-\mathrm{C} 21$ & $120.9(3)$ \\
\hline $\mathrm{C} 7-\mathrm{Fe} 1-\mathrm{C} 8$ & $40.41(11)$ & $\mathrm{C} 13-\mathrm{C} 12-\mathrm{C} 11$ & $120.5(3)$ \\
\hline $\mathrm{C} 6-\mathrm{Fe} 1-\mathrm{C} 8$ & $67.84(12)$ & $\mathrm{C} 21-\mathrm{C} 22-\mathrm{C} 23$ & $120.4(2)$ \\
\hline $\mathrm{C} 3-\mathrm{Fe} 1-\mathrm{C} 5$ & $68.16(12)$ & $\mathrm{C} 9-\mathrm{C} 8-\mathrm{C} 7$ & $108.0(3)$ \\
\hline $\mathrm{C} 2-\mathrm{Fe} 1-\mathrm{C} 5$ & $68.13(11)$ & $\mathrm{C} 9-\mathrm{C} 8-\mathrm{Fe} 1$ & $69.68(17)$ \\
\hline $\mathrm{C} 10-\mathrm{Fe} 1-\mathrm{C} 5$ & $109.30(12)$ & $\mathrm{C} 7-\mathrm{C} 8-\mathrm{Fe} 1$ & $69.63(16)$ \\
\hline $\mathrm{C} 4-\mathrm{Fe} 1-\mathrm{C} 5$ & $40.57(11)$ & $\mathrm{C} 11-\mathrm{C} 16-\mathrm{C} 15$ & $120.6(3)$ \\
\hline $\mathrm{C} 9-\mathrm{Fe} 1-\mathrm{C} 5$ & $128.55(12)$ & $\mathrm{C} 14-\mathrm{C} 15-\mathrm{C} 16$ & $119.3(3)$ \\
\hline $\mathrm{C} 7-\mathrm{Fe} 1-\mathrm{C} 5$ & $153.13(12)$ & $\mathrm{C} 3-\mathrm{C} 4-\mathrm{C} 5$ & $108.3(2)$ \\
\hline $\mathrm{C} 6-\mathrm{Fe} 1-\mathrm{C} 5$ & $119.96(12)$ & $\mathrm{C} 3-\mathrm{C} 4-\mathrm{Fe} 1$ & $69.41(16)$ \\
\hline $\mathrm{C} 8-\mathrm{Fe} 1-\mathrm{C} 5$ & $165.55(12)$ & $\mathrm{C} 5-\mathrm{C} 4-\mathrm{Fe} 1$ & $70.59(15)$ \\
\hline $\mathrm{C} 3-\mathrm{Fe} 1-\mathrm{C} 1$ & $68.23(11)$ & $\mathrm{C} 22-\mathrm{C} 23-\mathrm{C} 18$ & $121.3(2)$ \\
\hline $\mathrm{C} 2-\mathrm{Fe} 1-\mathrm{C} 1$ & $40.51(10)$ & $\mathrm{O} 1-\mathrm{C} 14-\mathrm{C} 13$ & $115.3(3)$ \\
\hline $\mathrm{C} 10-\mathrm{Fe} 1-\mathrm{C} 1$ & $127.92(12)$ & $\mathrm{C} 8-\mathrm{Fe} 1-\mathrm{C} 1$ & $152.56(11)$ \\
\hline $\mathrm{C} 4-\mathrm{Fe} 1-\mathrm{C} 1$ & $68.06(11)$ & $\mathrm{C} 5-\mathrm{Fe} 1-\mathrm{C} 1$ & $40.34(10)$ \\
\hline $\mathrm{C} 9-\mathrm{Fe} 1-\mathrm{C} 1$ & $165.82(12)$ & $\mathrm{C} 1-\mathrm{N} 1-\mathrm{C} 18$ & $124.0(2)$ \\
\hline
\end{tabular}


$\mathrm{C} 7-\mathrm{Fe} 1-\mathrm{C} 1$

$118.78(11)$

$\mathrm{C} 1-\mathrm{N} 1-\mathrm{C} 11$

$114.3(2)$

$\mathrm{C} 6-\mathrm{Fe} 1-\mathrm{C} 1$

$108.18(11)$
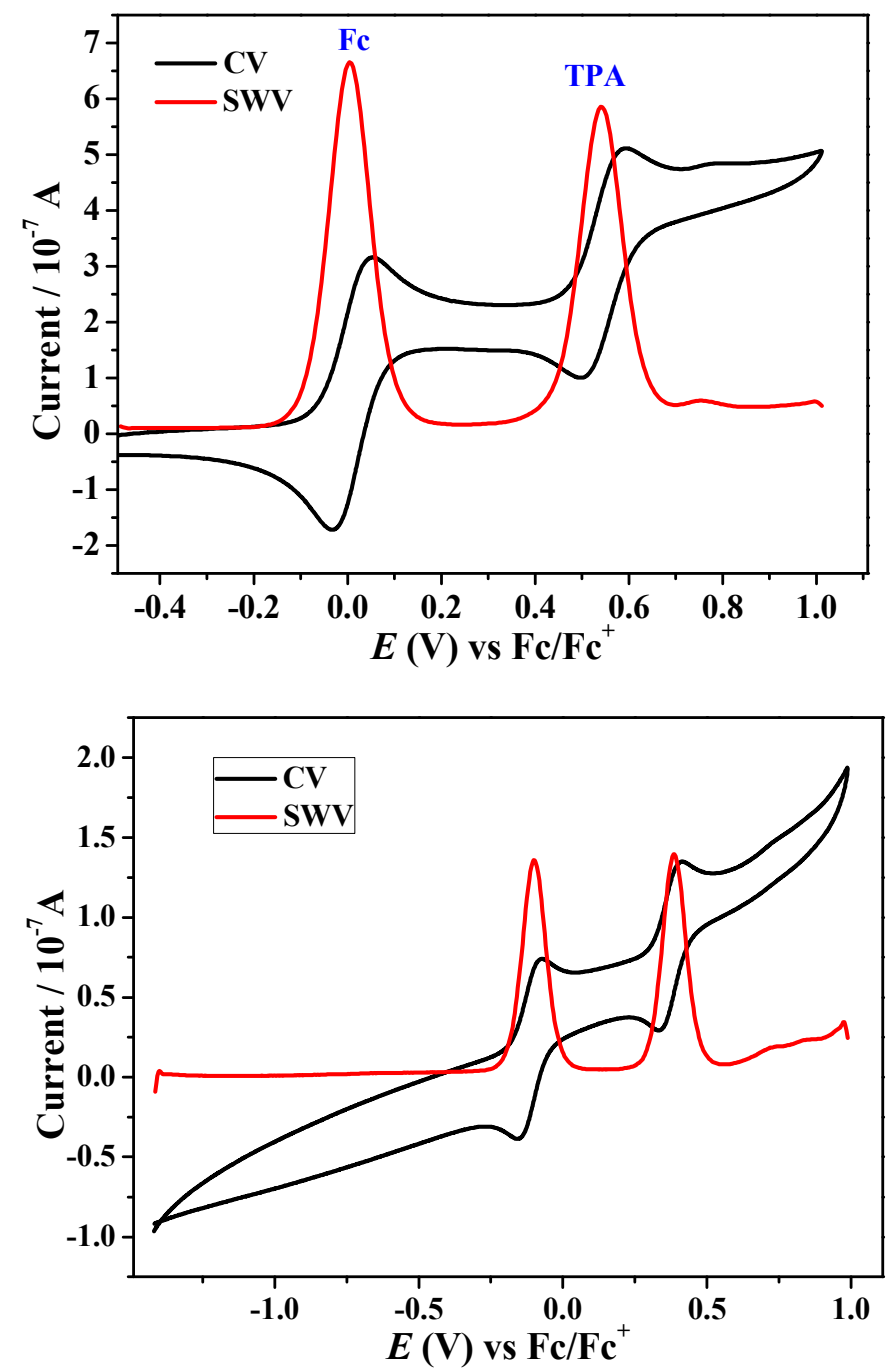

Figure S1. Cyclic voltammograms (CV, at $v=50 \mathrm{mV} \mathrm{s}^{-1}$; black line) and corresponding square-wave voltammograms ( $\mathrm{SWV}$, at $f=10 \mathrm{~Hz}$ and $t_{\mathrm{p}}=25 \mathrm{mV}$; red line) of TPA (top, with ferrocene present as the internal standard), and M4TPPD (bottom) in $\mathrm{CH}_{2} \mathrm{Cl}_{2} / n-\mathrm{Bu}_{4} \mathrm{NPF} 6$. 


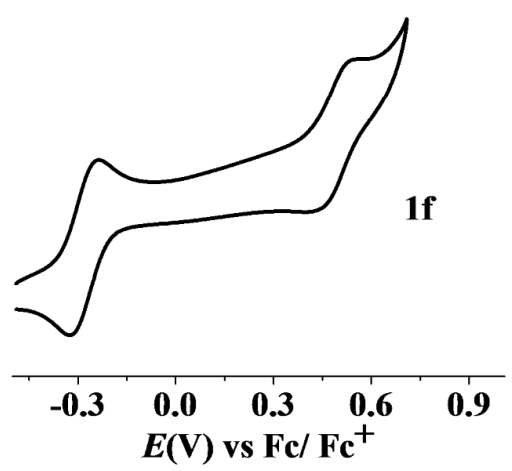

Figure S2. The curtailed two-anodic-step cyclic voltammogram (CV) of $\mathbf{1 f}$ in $\mathrm{CH}_{2} \mathrm{Cl}_{2} / n$ - $\mathrm{Bu}_{4} \mathrm{NPF}_{6}$ at $v=50 \mathrm{mV} \mathrm{s}^{-1}$.

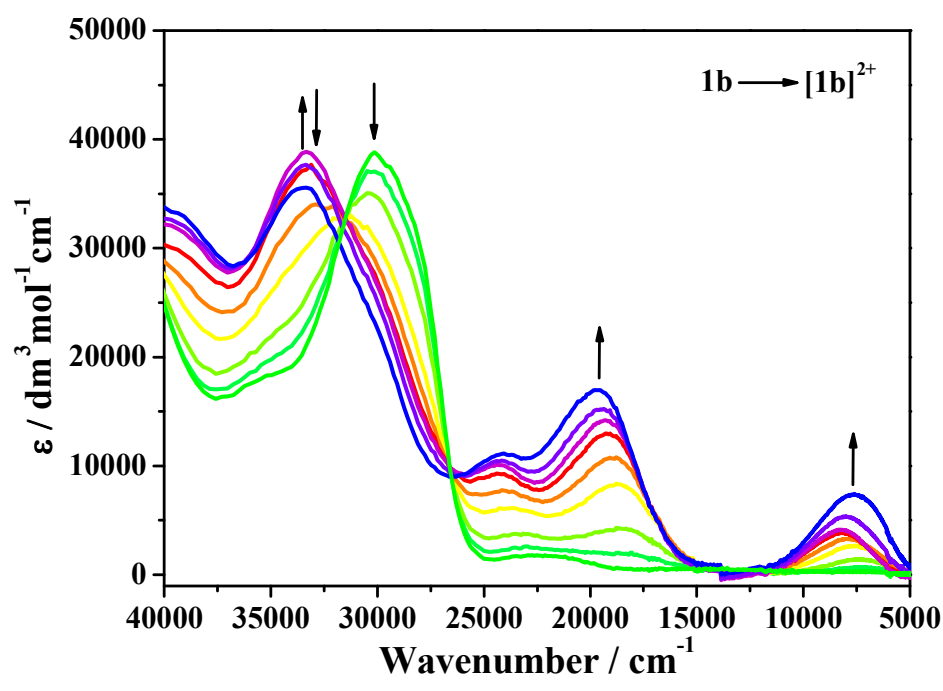

Figure S3. Changes in UV-vis-NIR absorption spectra recorded during the oxidation of complex 1b to $[\mathbf{1 b}]^{2+}$ in $\mathrm{CH}_{2} \mathrm{Cl}_{2} / 10^{-1} \mathrm{M} n-\mathrm{Bu}_{4} \mathrm{NPF}_{6}$ at $298 \mathrm{~K}$ within an OTTLE cell. The intermediate absorption of $[\mathbf{1 b}]^{+}$is poorly resolved due to pronounced redox disproportionation of the monocation. 

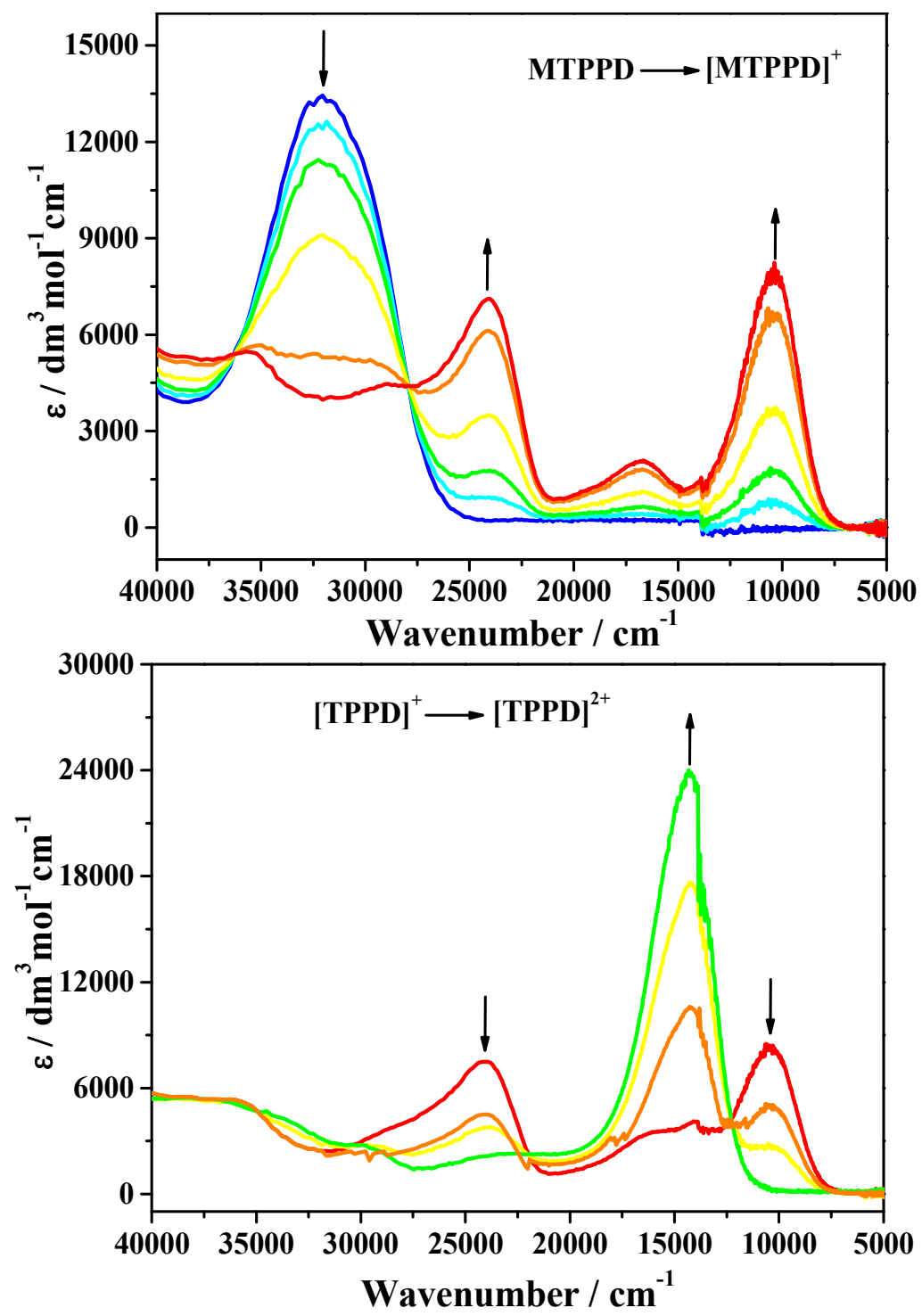

Figure S4. Changes in UV-vis-NIR absorption spectra recorded during the oxidation of reference compound MTPPD to [MTPPD] $]^{+}$(top) and [MTPPD $]^{2+}$ (bottom) in $\mathrm{CH}_{2} \mathrm{Cl}_{2} / 10^{-1} \mathrm{M} n$ - $\mathrm{Bu}_{4} \mathrm{NPF}_{6}$ at $298 \mathrm{~K}$ within an OTTLE cell. 


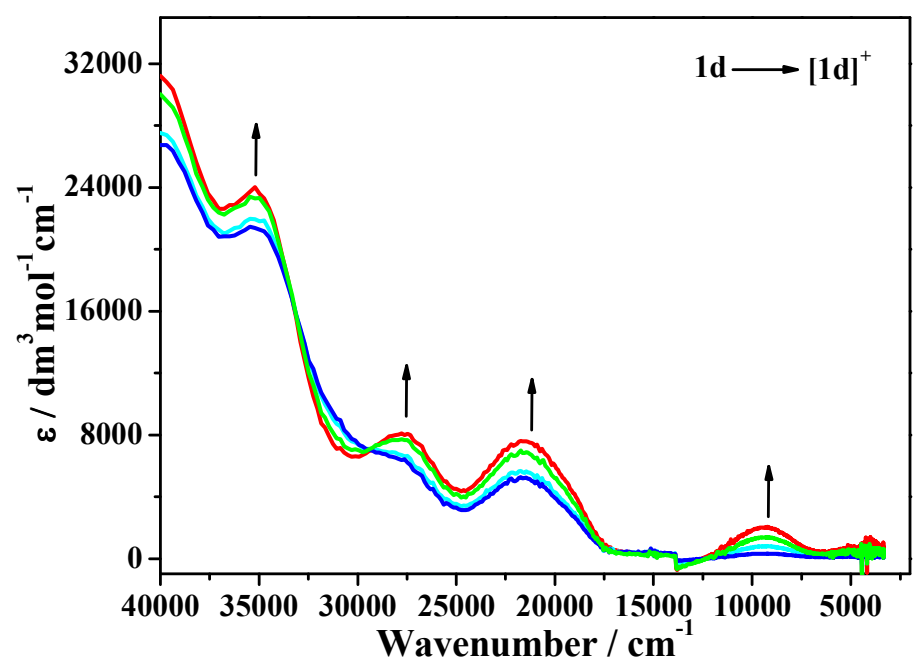

Figure S5. UV-vis-NIR spectral changes recorded during the reversible Fc-localized oxidation of complex 1d to $[\mathbf{1 d}]^{+}$in $\mathrm{CH}_{2} \mathrm{Cl}_{2} / 10^{-1} \mathrm{M} n-\mathrm{Bu}_{4} \mathrm{NPF}_{6}$ at $298 \mathrm{~K}$ within an OTTLE cell.

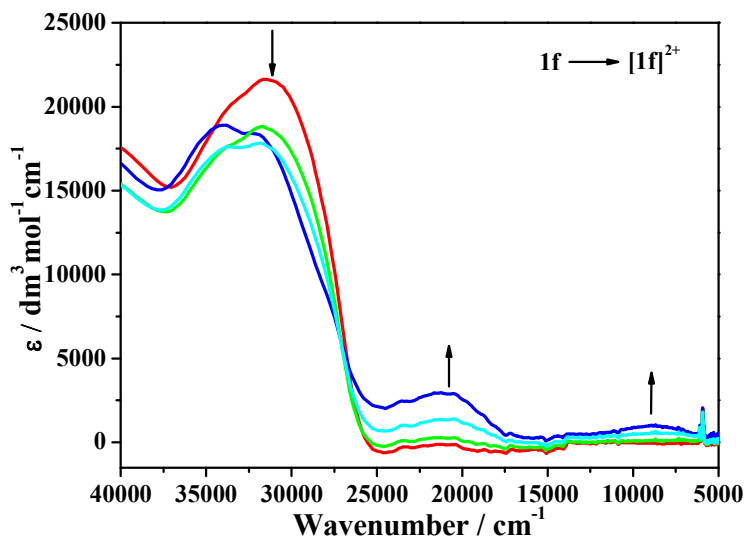

Figure S6. Changes in UV-vis-NIR absorption recorded during the unresolved bielectronic oxidation of dinuclear complex $\mathbf{1 f}$ to $[\mathbf{1 f}]^{2+}$ in $\mathrm{CH}_{2} \mathrm{Cl}_{2} / 10^{-1} \mathrm{M} n-\mathrm{Bu}_{4} \mathrm{NPF}_{6}$ at $298 \mathrm{~K}$ within an OTTLE cell. The subsequent oxidation to $[\mathbf{1} \mathbf{f}]^{3+}$ was complicated by low solubility of the ultimate product. 


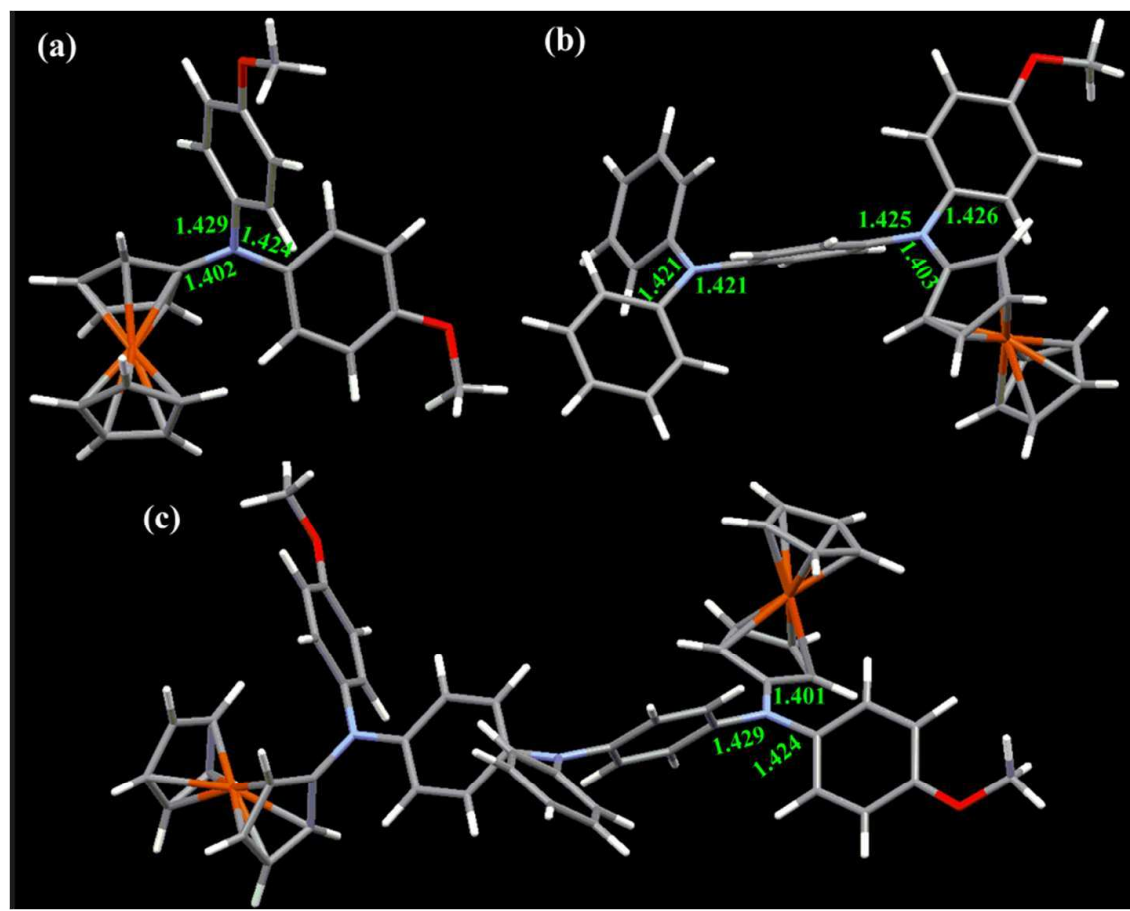

Figure S7. The DFT-optimized geometric structures of $\mathbf{1 d}(\mathrm{a}), \mathbf{1 e}(\mathrm{b})$ and $\mathbf{1 f}(\mathrm{c})$.

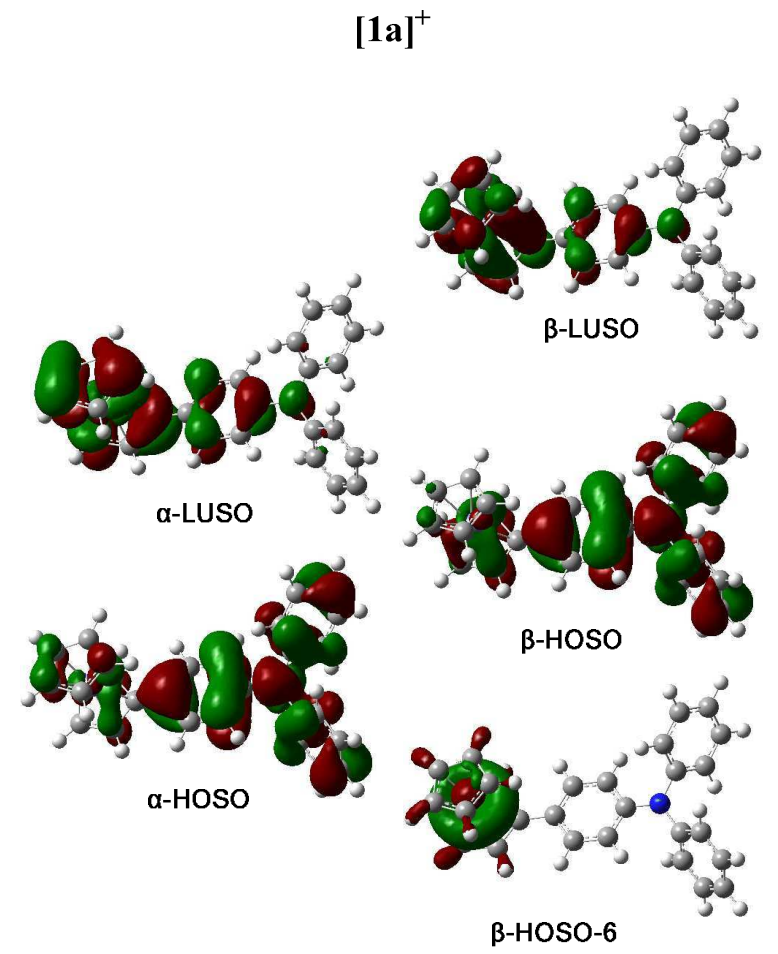

Figure S8. Spin orbitals involved in the major electronic excitations of [1a] $]^{+}$. B3LYP /6-31G* $(\mathrm{Fe}$ : Lanl2DZ) /CPCM $/ \mathrm{CH}_{2} \mathrm{Cl}_{2}$. 


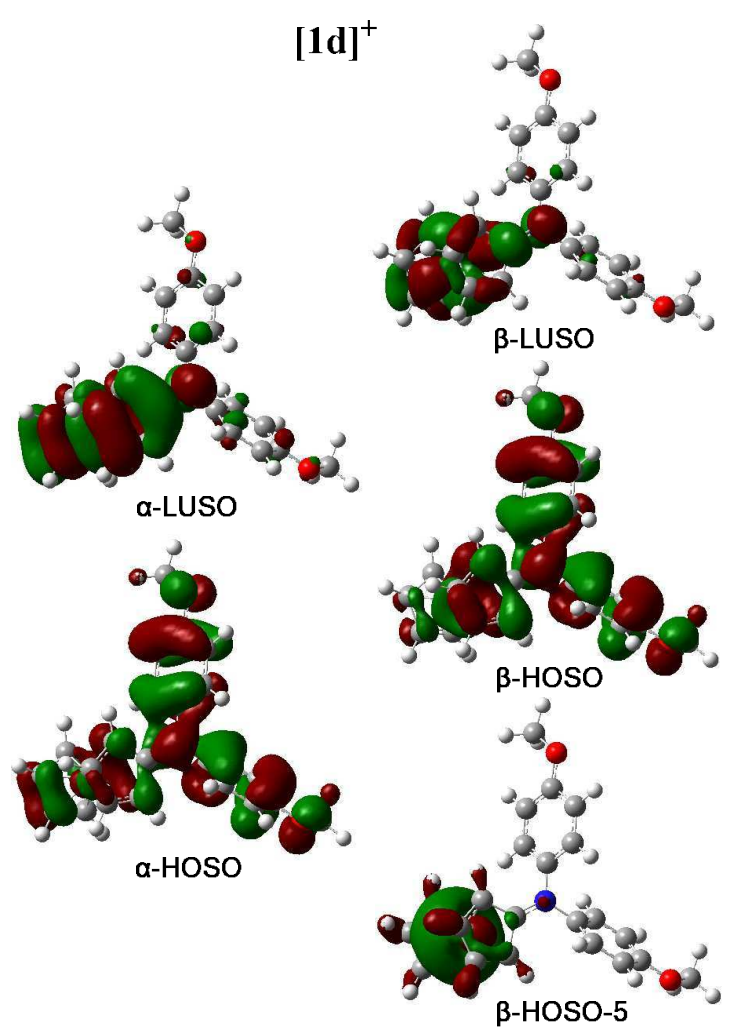

Figure S9. Spin orbitals involved in the major electronic excitations of [1d $]^{+}$. B3LYP /6-31G* (Fe: Lanl2DZ) /CPCM $/ \mathrm{CH}_{2} \mathrm{Cl}_{2}$. 

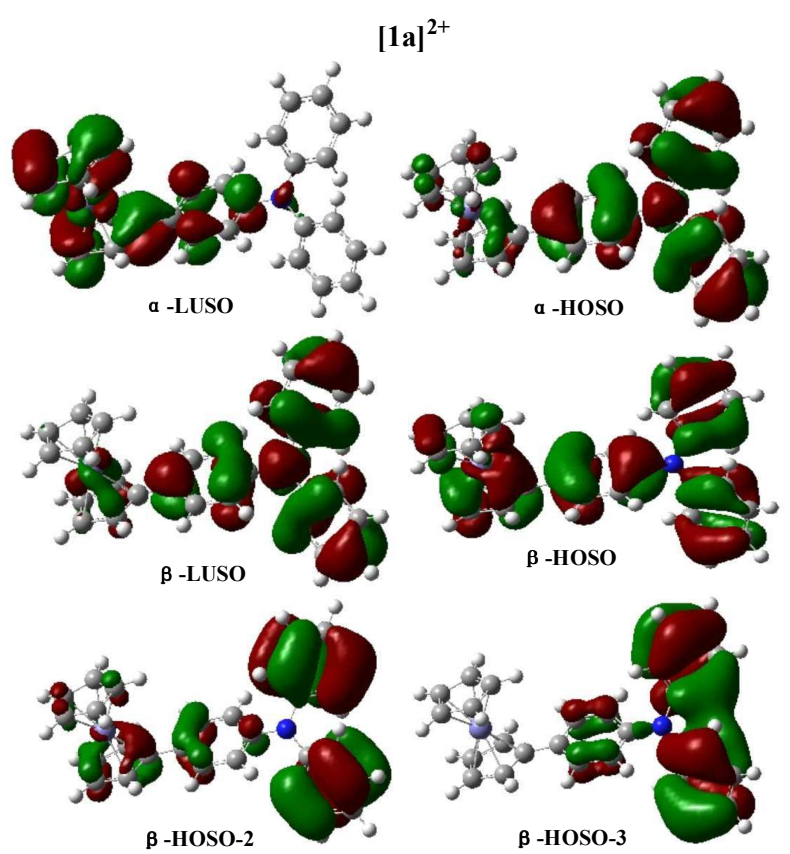

Figure S10. Spin orbitals involved in the major electronic excitations of $[\mathbf{1 a}]^{2+}$ (biradical state). B3LYP /6-31G* (Fe: Lanl2DZ) /CPCM / $\mathrm{CH}_{2} \mathrm{Cl}_{2}$.

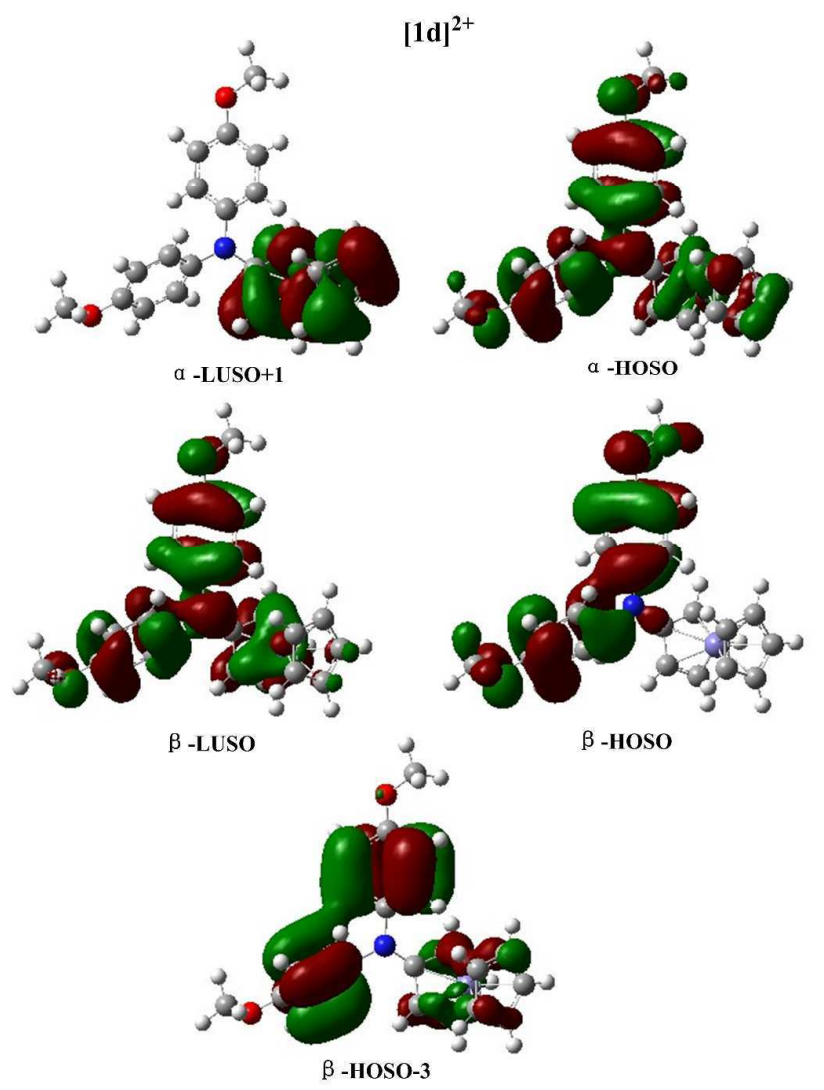

Figure S11. Spin orbitals involved in the major electronic excitations of $[\mathbf{1 d}]^{2+}$ (biradical state). 
B3LYP /6-31G* (Fe: Lanl2DZ) /CPCM / $\mathrm{CH}_{2} \mathrm{Cl}_{2}$.
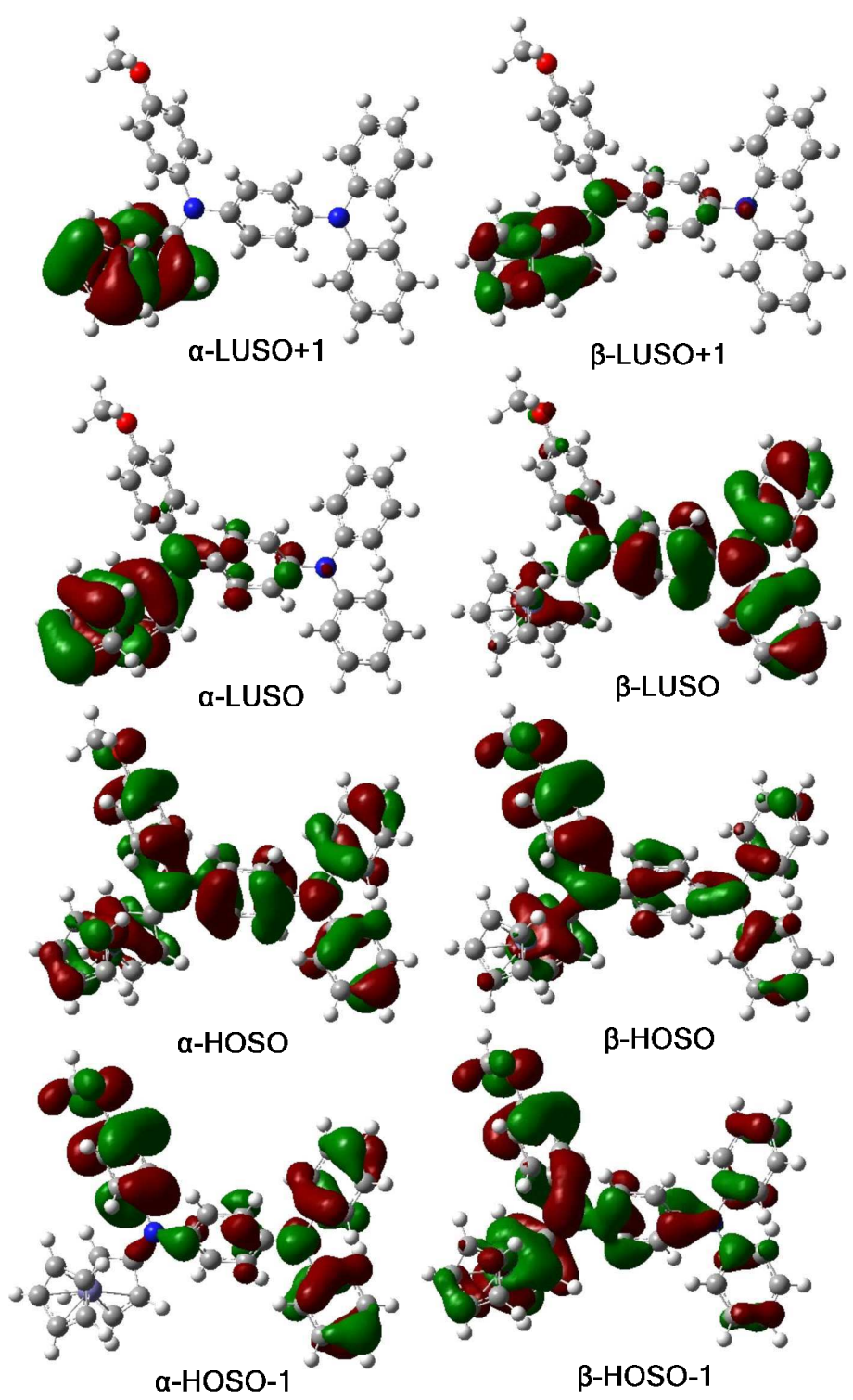

Figure S12. Frontier spin orbitals of $[1 \mathbf{e}]^{2+}$ (biradical state). B3LYP /6-31G* (Fe: Lanl2DZ) $/ \mathrm{CPCM} / \mathrm{CH}_{2} \mathrm{Cl}_{2}$. 


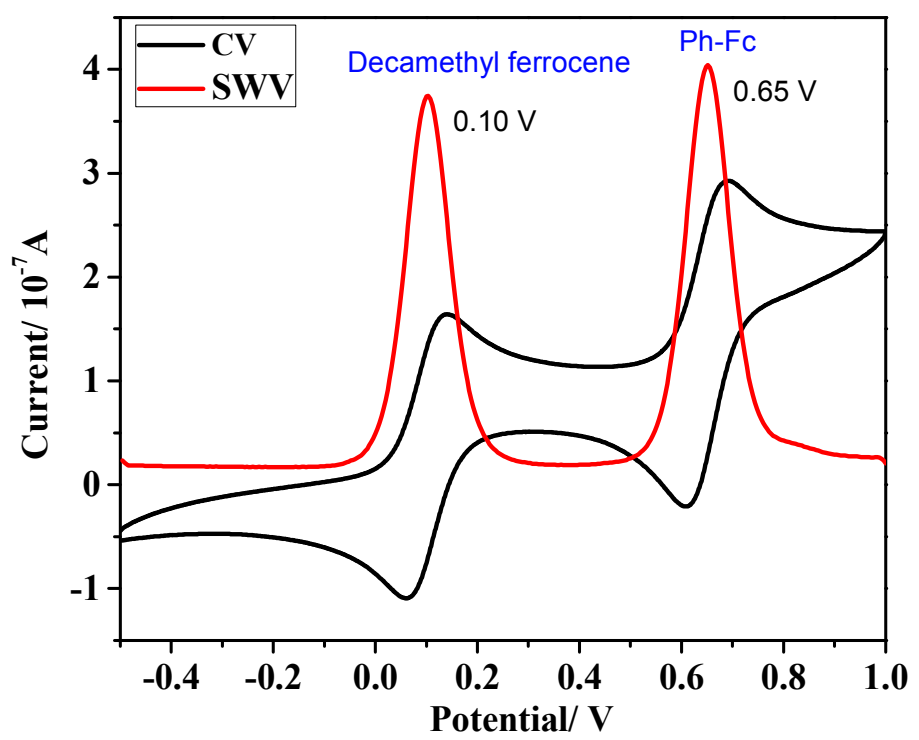

Figure S13. The cyclic voltammogram $\left(\mathrm{CV}\right.$, black line; $\left.v=50 \mathrm{mV} \mathrm{s}^{-1}\right)$ and the corresponding square-wave voltammogram ( $\mathrm{SWV}$, red line; at $f=10 \mathrm{~Hz}$ and $t_{\mathrm{p}}=25 \mathrm{mV}$ ) of reference phenylferrocene, $\mathrm{Ph}-\mathrm{Fc}$, in $\mathrm{CH}_{2} \mathrm{Cl}_{2} / n-\mathrm{Bu}_{4} \mathrm{NPF}_{6}$. The oxidation potential of $\mathrm{Ph}-\mathrm{Fc}$ is $E_{1 / 2}=+0.04 \mathrm{~V}$ vs ferrocene/ferrocenium $\left(\mathrm{Fc} / \mathrm{Fc}^{+}\right)$. The electronic absorption of $[\mathrm{Ph}-\mathrm{Fc}]^{+}$is presented in Figure S14.

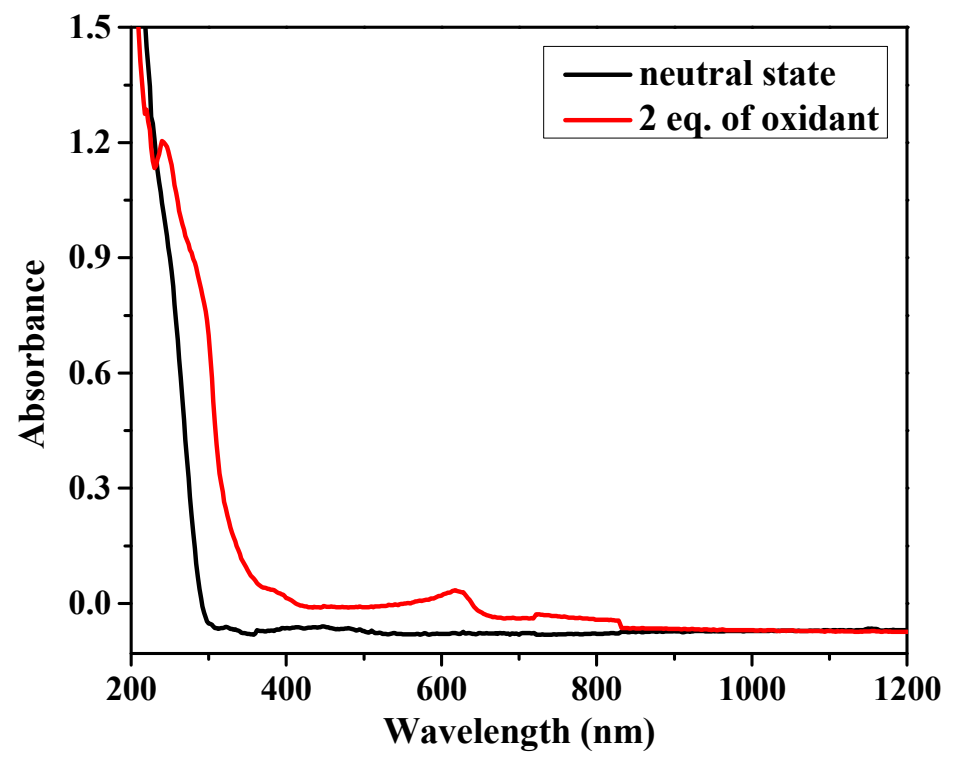

Figure S14. Electronic absorption spectra of $10^{-2} \mathrm{M} \mathrm{Ph}-\mathrm{Fc}$ (black line) and $[\mathrm{Ph}-\mathrm{Fc}]^{+}$(red line) obtained by chemical oxidation with $\mathrm{AgPF}_{6}$ in $\mathrm{CH}_{2} \mathrm{Cl}_{2}$ at $298 \mathrm{~K}$. The simulated spectra of $[\mathrm{Ph}-\mathrm{Fc}]^{+}$ and corresponding electronic transitions obtained with TD-DFT methods are depicted in Figures S15-S17. 


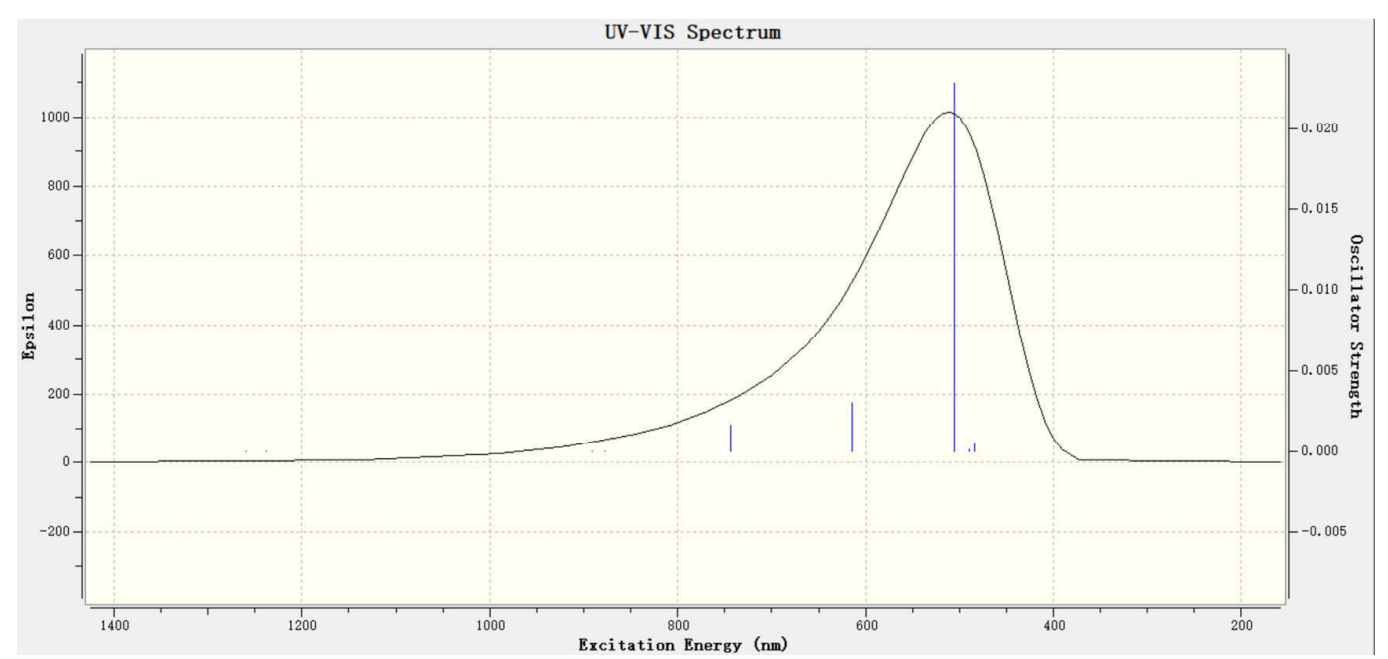

Figure S15. Simulated electronic absorption of $[\mathrm{Ph}-\mathrm{Fc}]^{+}$. B3LYP/6-31G*/CPCM $/ \mathrm{CH}_{2} \mathrm{Cl}_{2}$.

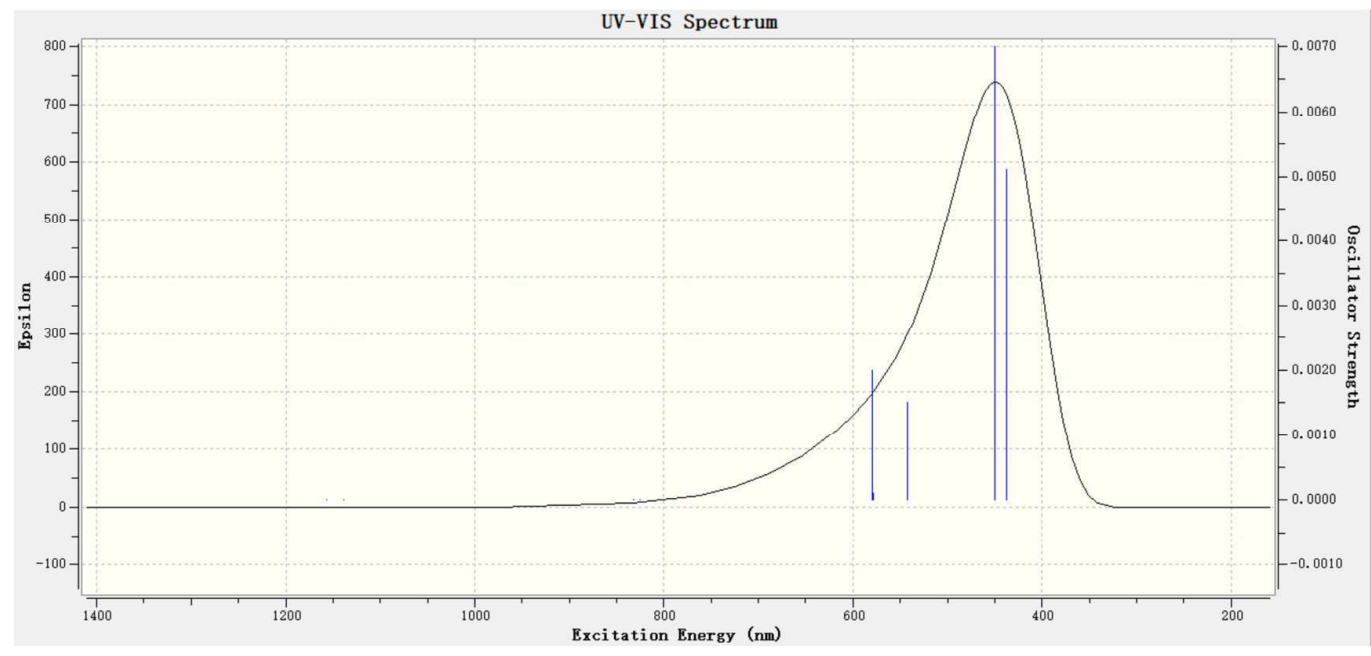

Figure S16. Simulated electronic absorption of $[\mathrm{Ph}-\mathrm{Fc}]^{+}$; CAM-B3LYP/6-31G*/CPCM / $\mathrm{CH}_{2} \mathrm{Cl}_{2}$. 


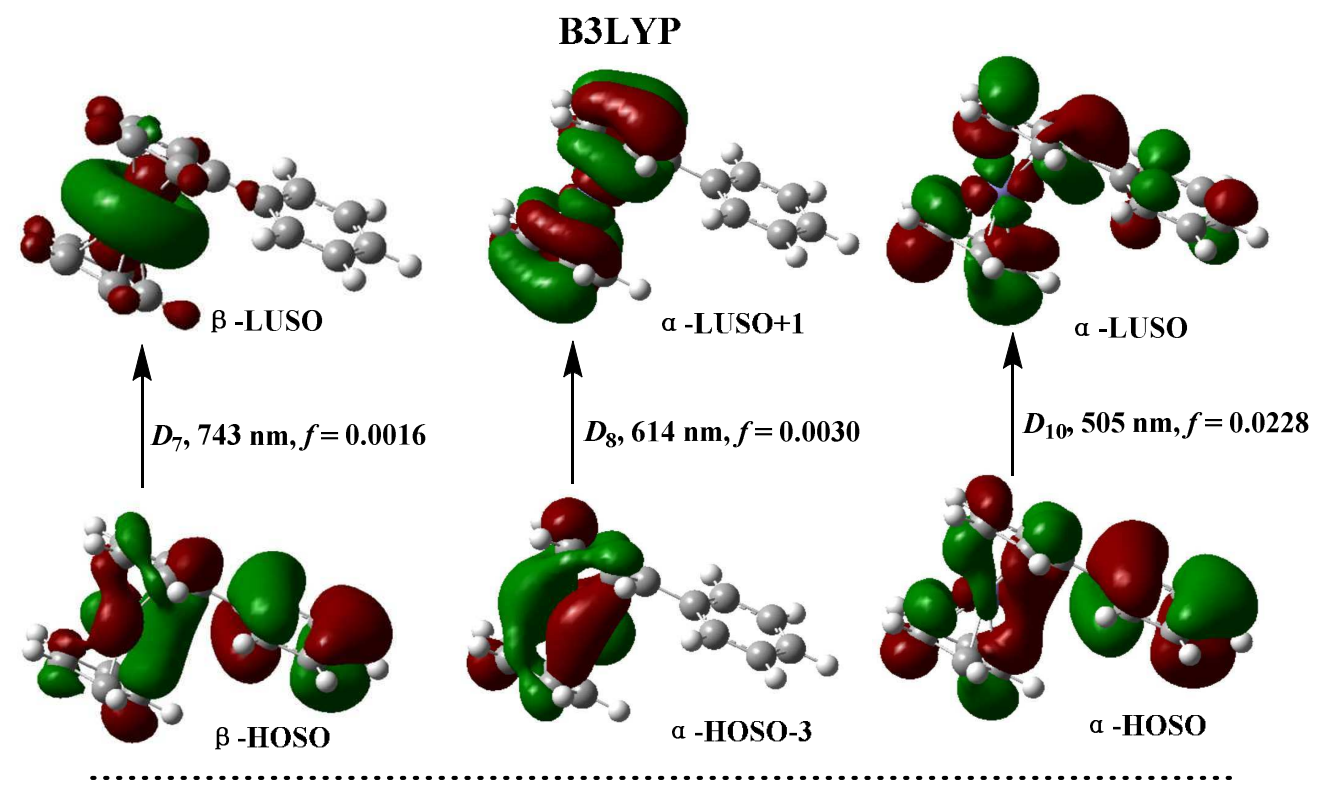

CAM-B3LYP

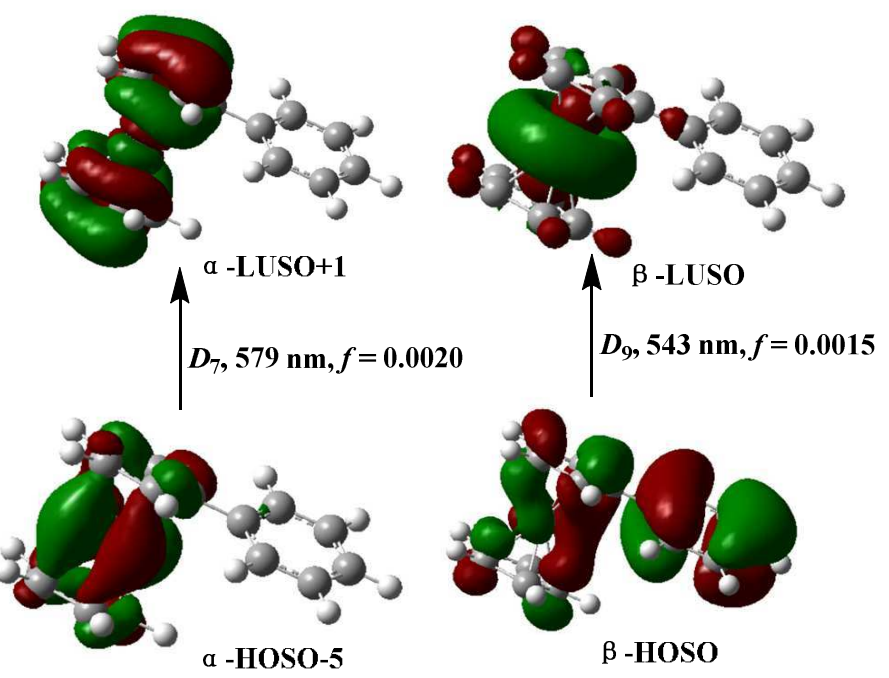

Figure S17. Spin orbitals involved in the plausible calculated visible electronic excitations of $[\mathrm{Ph}-\mathrm{Fc}]^{+}$(see Figures S15 and S16). A better agreement with the experimental visible absorption of the cationic complex has been reached with the B3LYP method.

\section{NMR Spectra}



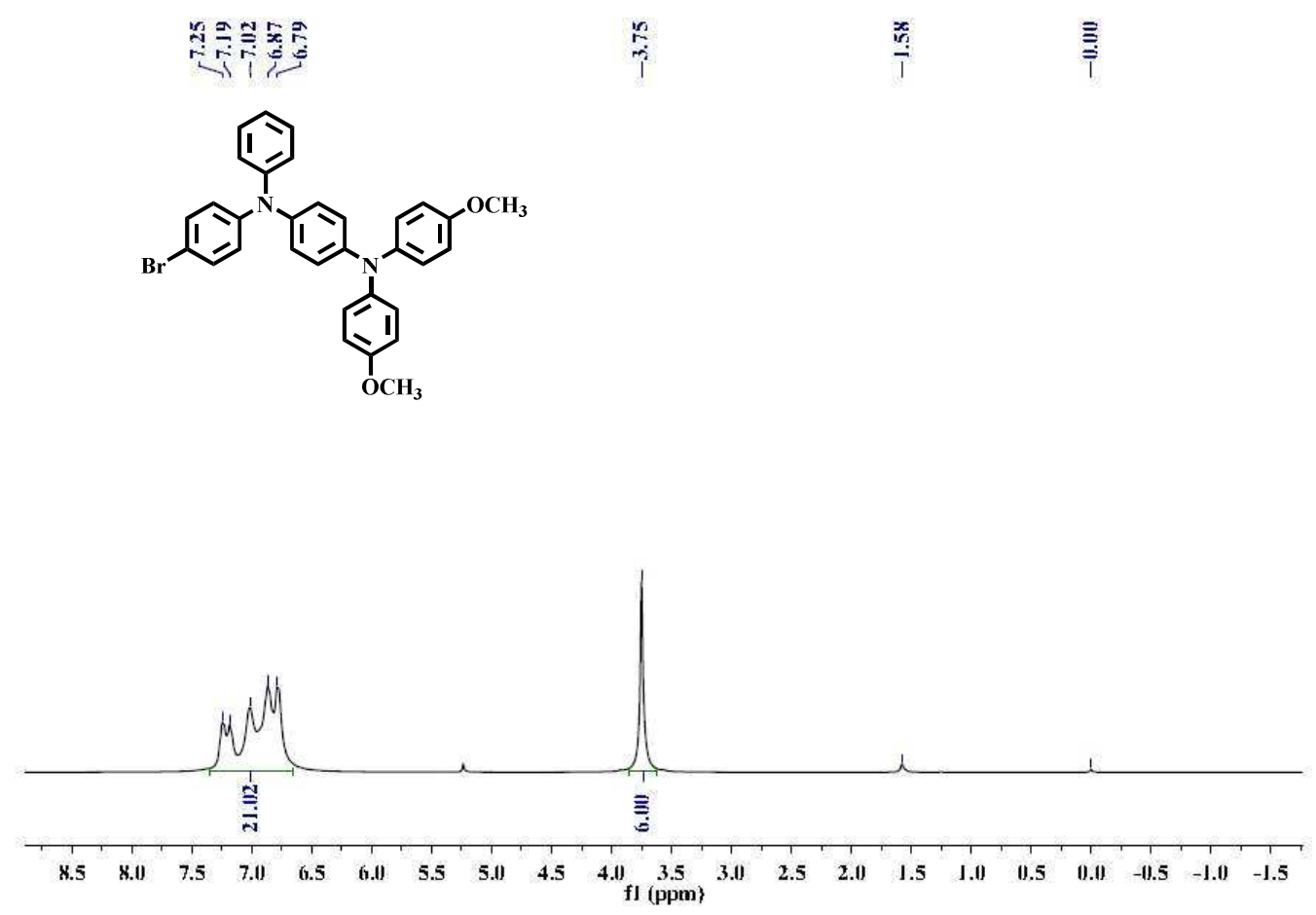

Figure S18. ${ }^{1} \mathrm{H}$ NMR spectrum $\left(400 \mathrm{MHz}, \mathrm{CDCl}_{3}\right)$ of $\mathbf{2 c}$.

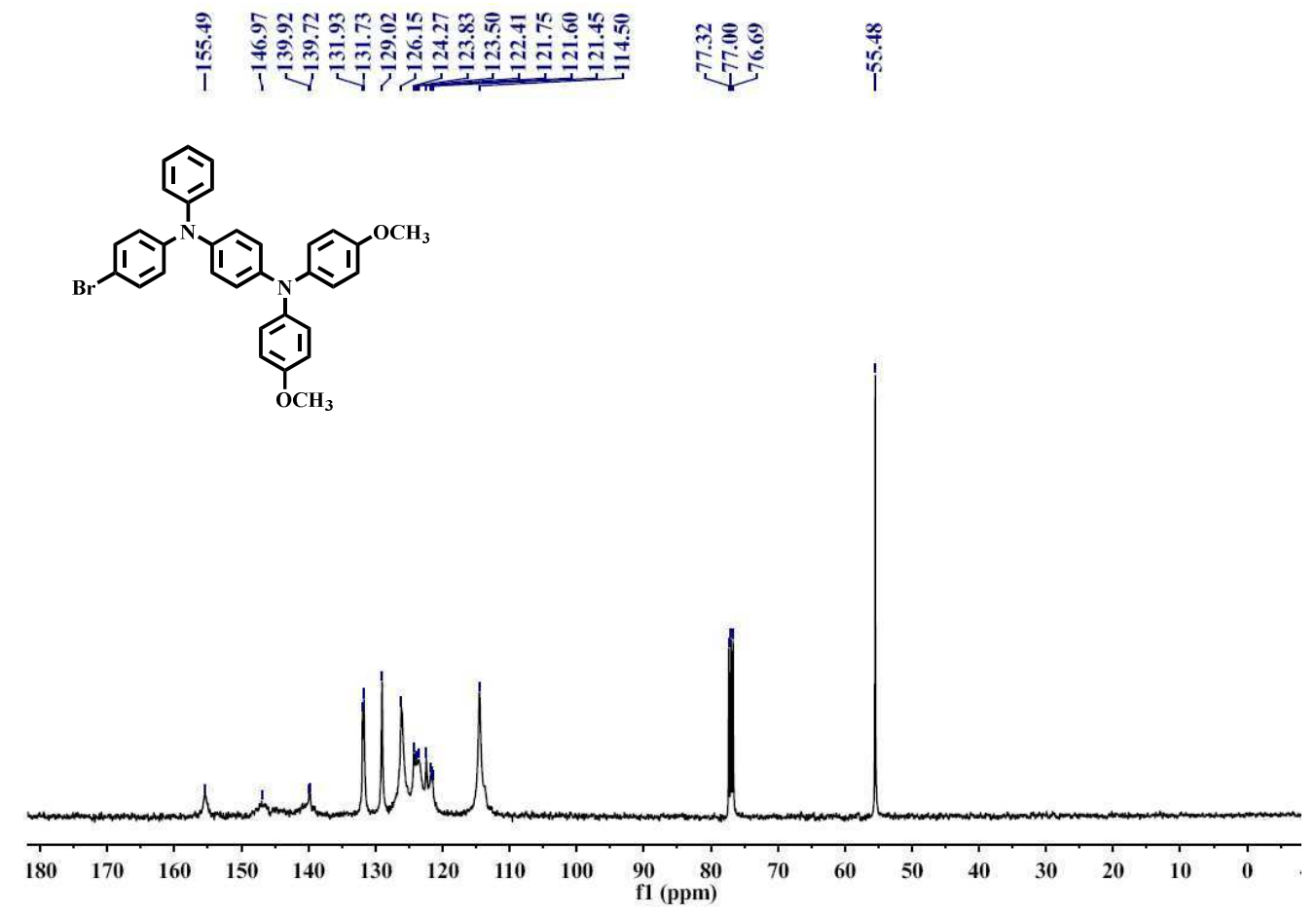

Figure S19. ${ }^{13} \mathrm{C}$ NMR spectrum $\left(100 \mathrm{MHz}, \mathrm{CDCl}_{3}\right)$ of $\mathbf{2 c}$. 


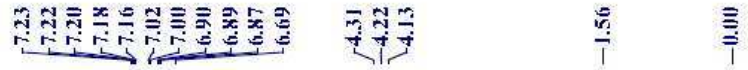<smiles></smiles>

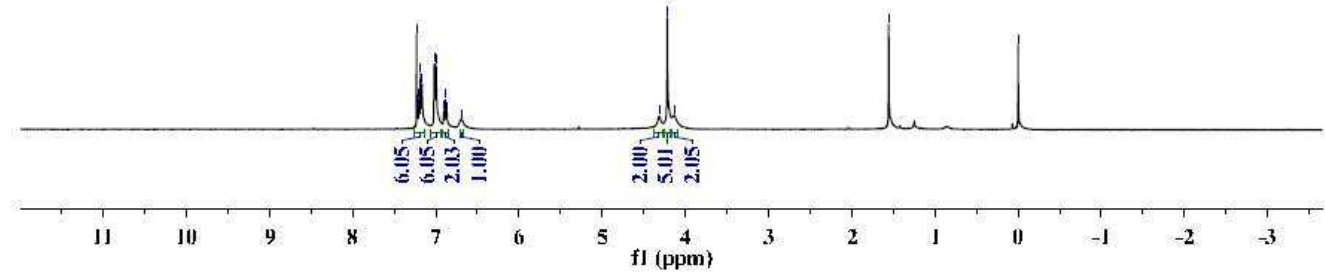

Figure S20. ${ }^{1} \mathrm{H}$ NMR spectrum $\left(400 \mathrm{MHz}, \mathrm{CDCl}_{3}\right)$ of $\mathbf{2 e}$.
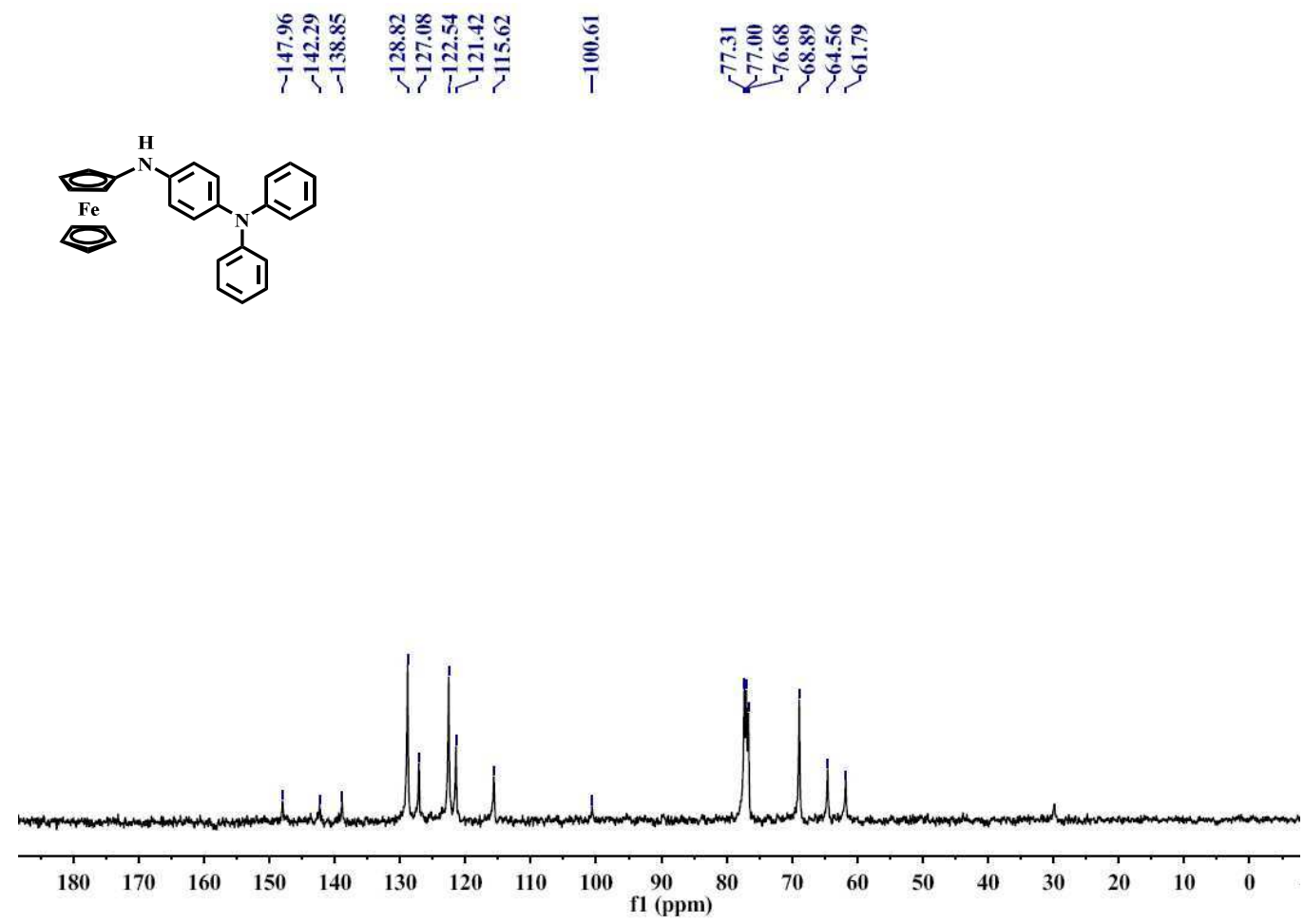

Figure S21. ${ }^{13} \mathrm{C}$ NMR spectrum $\left(100 \mathrm{MHz}, \mathrm{CDCl}_{3}\right)$ of $\mathbf{2 e}$. 


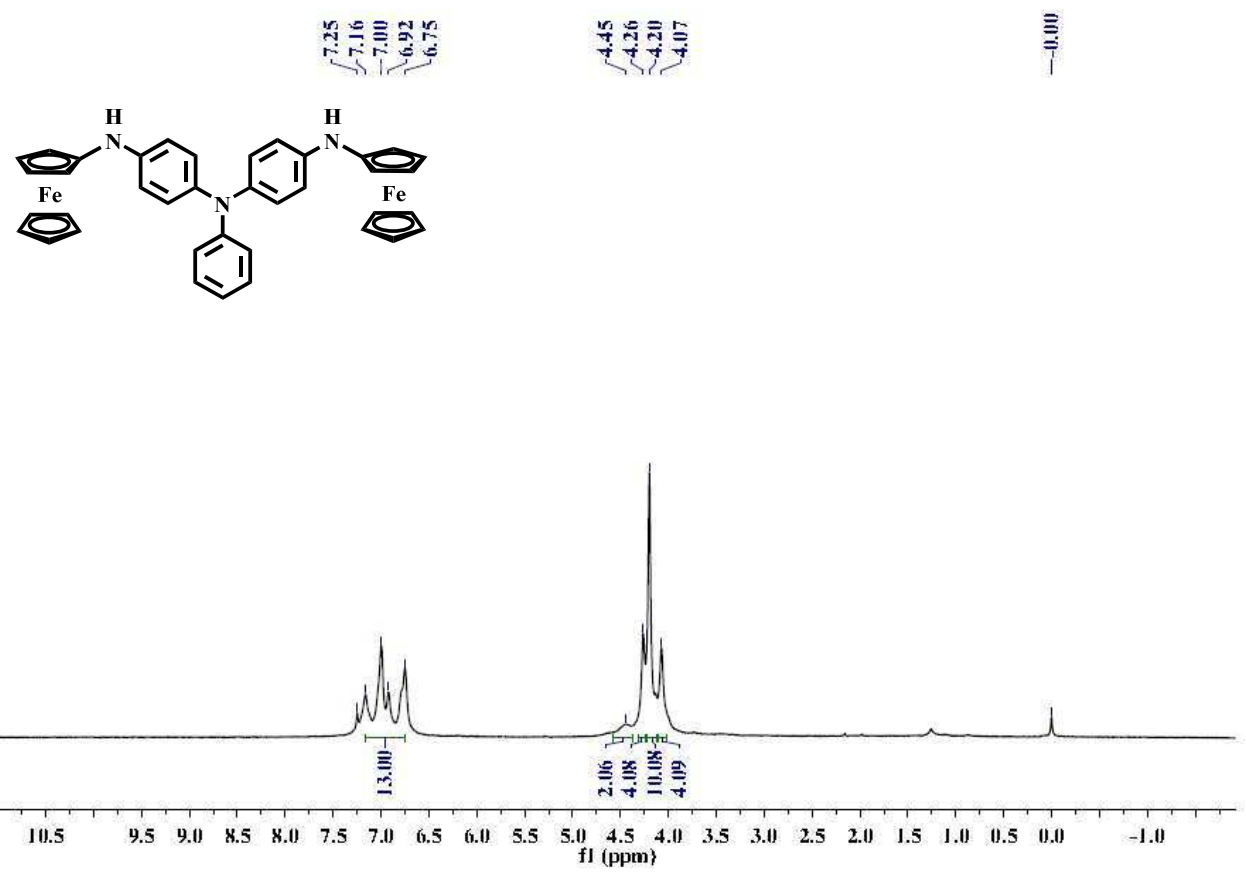

Figure S22. ${ }^{1} \mathrm{H}$ NMR spectrum $\left(600 \mathrm{MHz}, \mathrm{CDCl}_{3}\right)$ of $\mathbf{2 f}$.

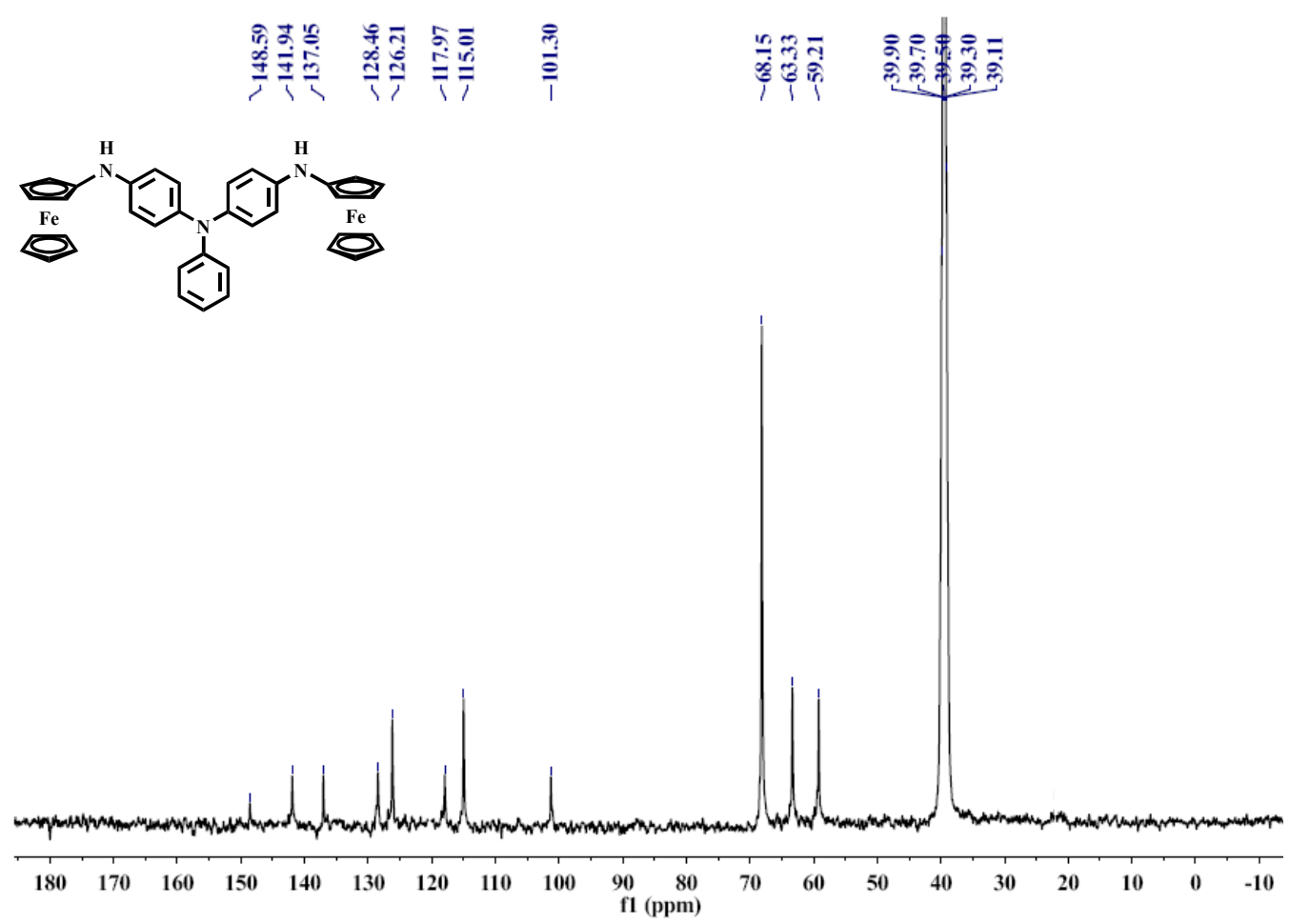

Figure S23. ${ }^{13} \mathrm{C}$ NMR spectrum $\left(100 \mathrm{MHz}\right.$, DMSO-d $\left.\mathrm{d}_{6}\right)$ of $\mathbf{2 f}$. 
Dalton Transactions

Page 114 of 119
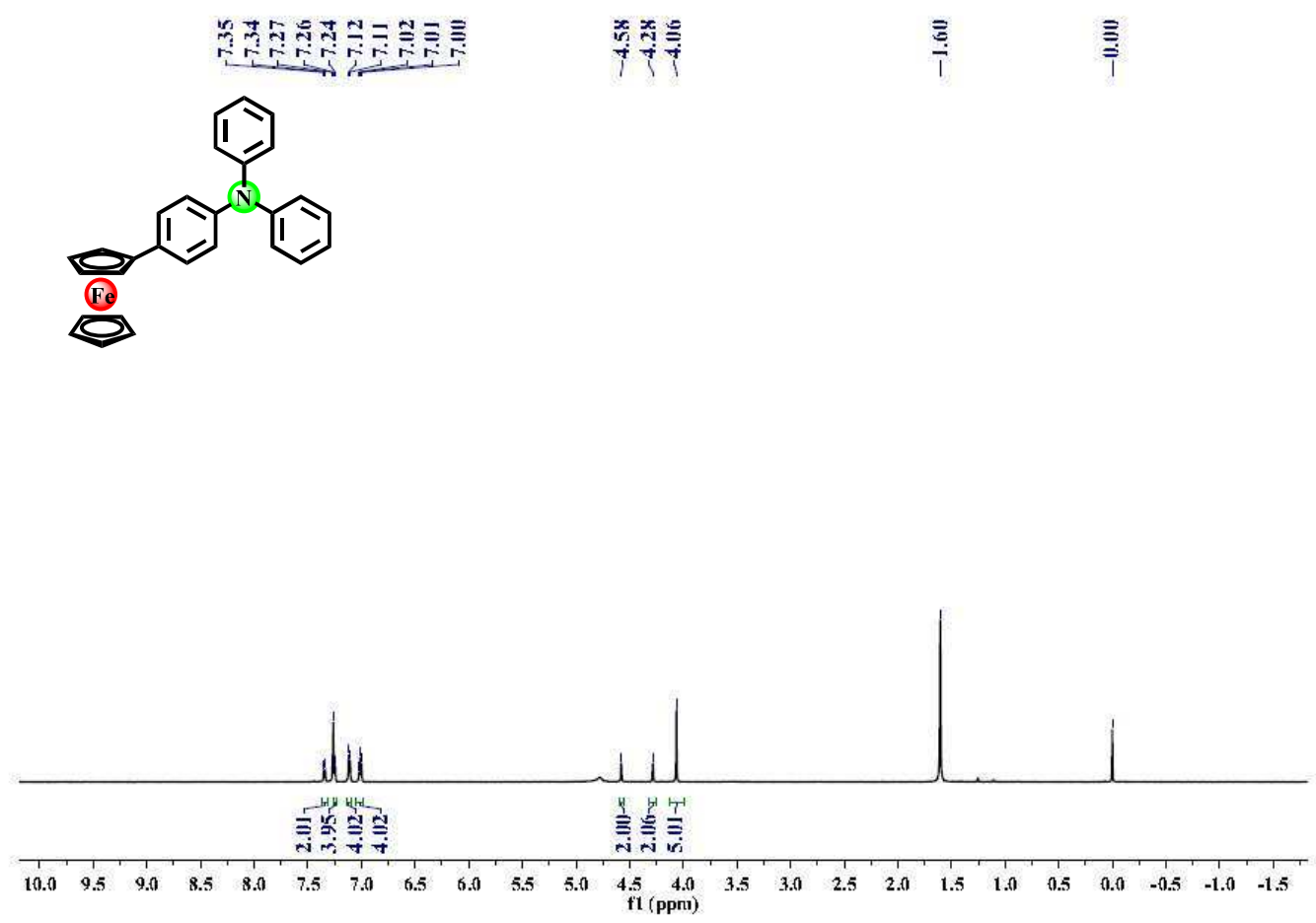

Figure S24. ${ }^{1} \mathrm{H}$ NMR spectrum $\left(400 \mathrm{MHz}, \mathrm{CDCl}_{3}\right)$ of $\mathbf{1 a}$.

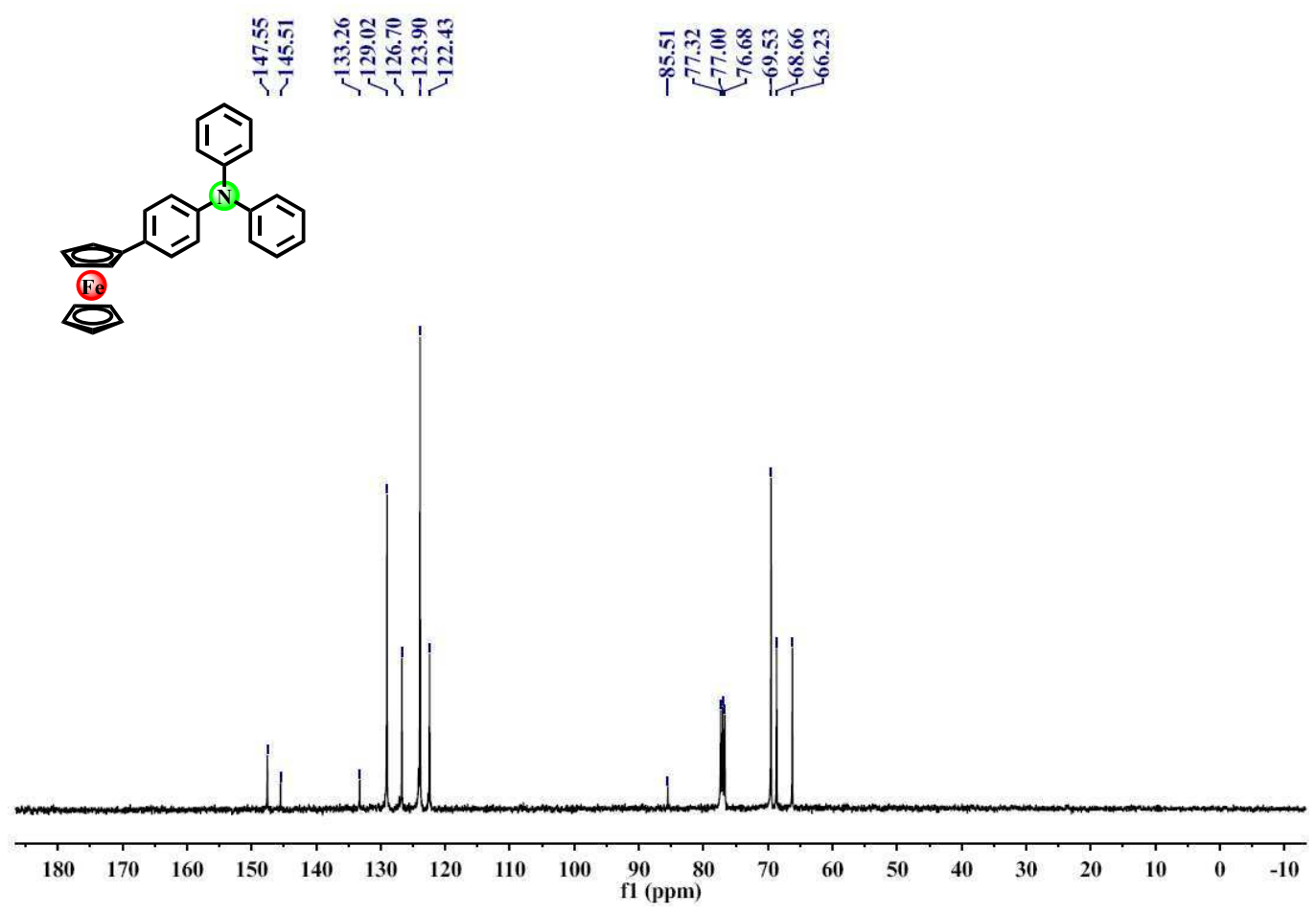

Figure S25. ${ }^{13} \mathrm{C}$ NMR spectrum $\left(100 \mathrm{MHz}, \mathrm{CDCl}_{3}\right)$ of $\mathbf{1 a}$. 


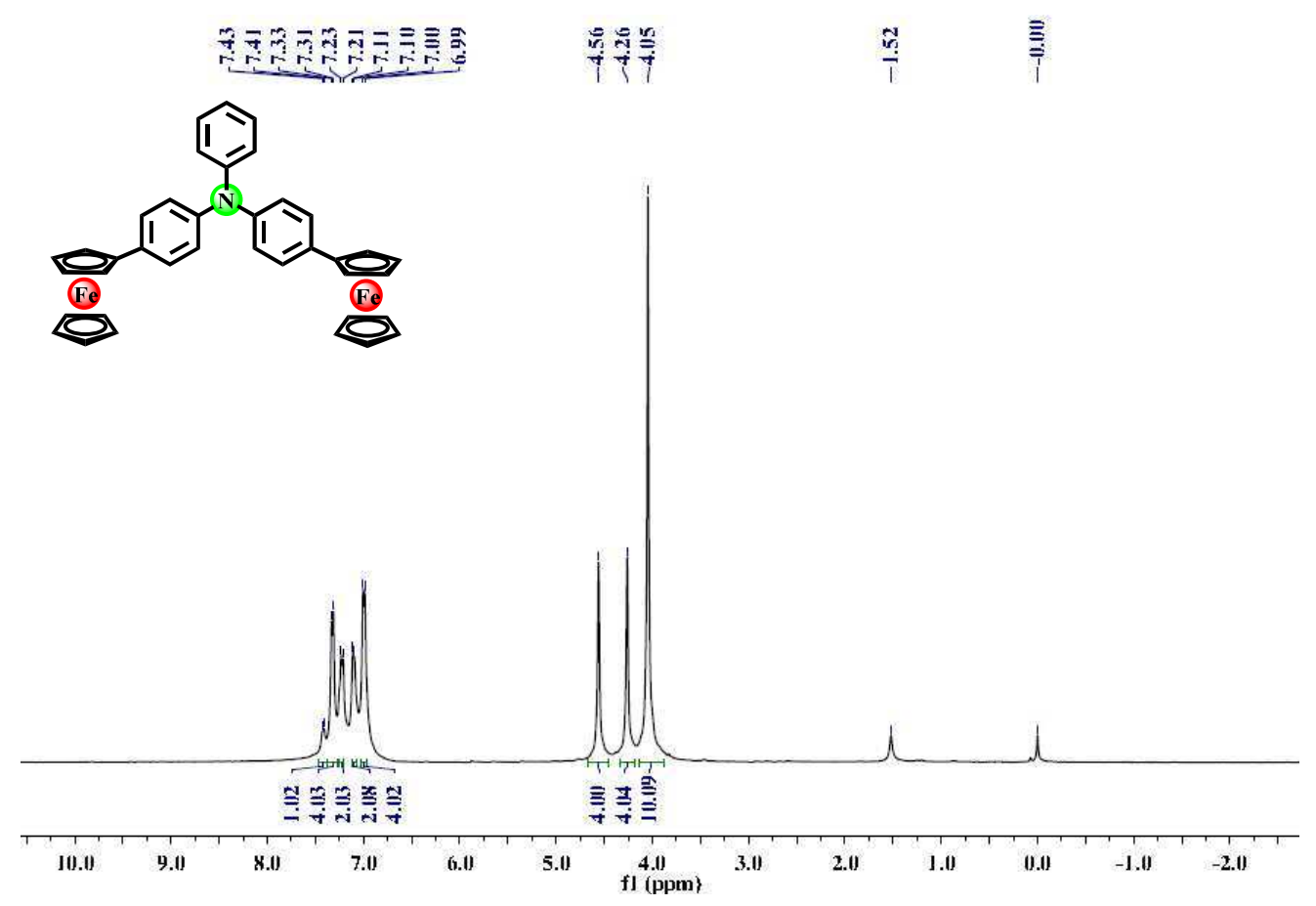

Figure S26. ${ }^{1} \mathrm{H}$ NMR spectrum $\left(400 \mathrm{MHz}, \mathrm{CDCl}_{3}\right)$ of $\mathbf{1 b}$.

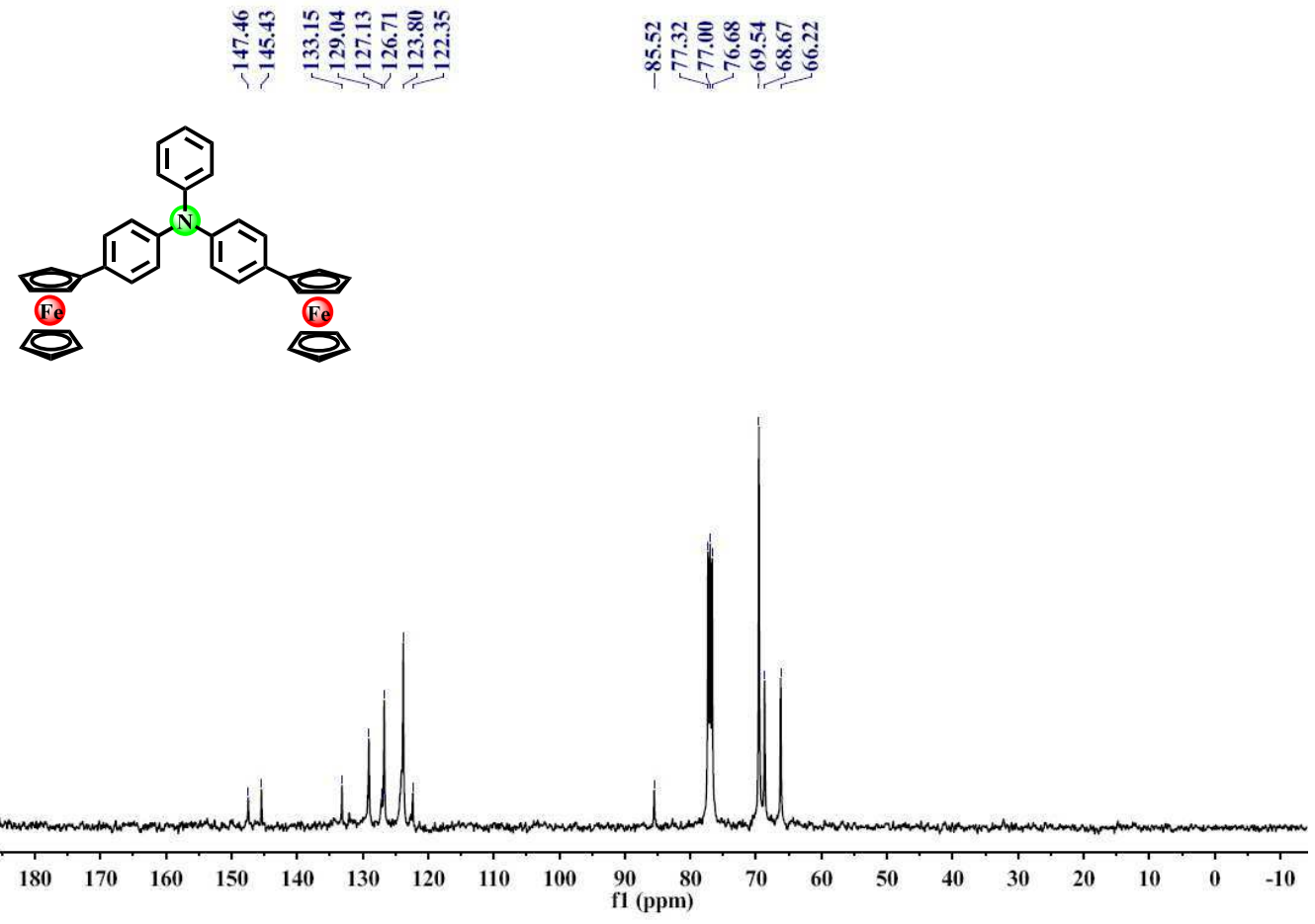

Figure S27. ${ }^{13} \mathrm{C}$ NMR spectrum $\left(100 \mathrm{MHz}, \mathrm{CDCl}_{3}\right)$ of $\mathbf{1 b}$. 

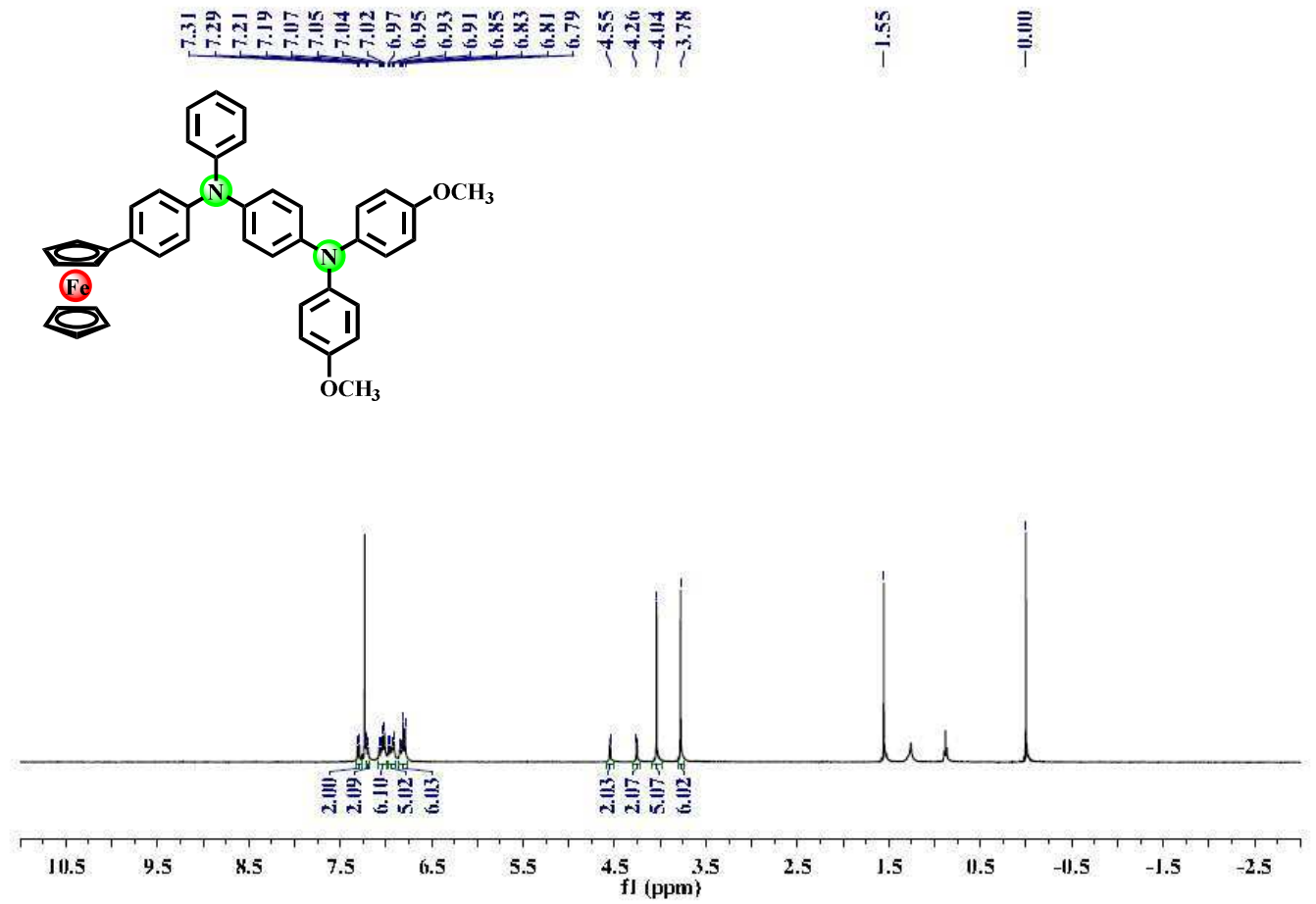

Figure S28. ${ }^{1} \mathrm{H}$ NMR spectrum $\left(400 \mathrm{MHz}, \mathrm{CDCl}_{3}\right)$ of $\mathbf{1 c}$.
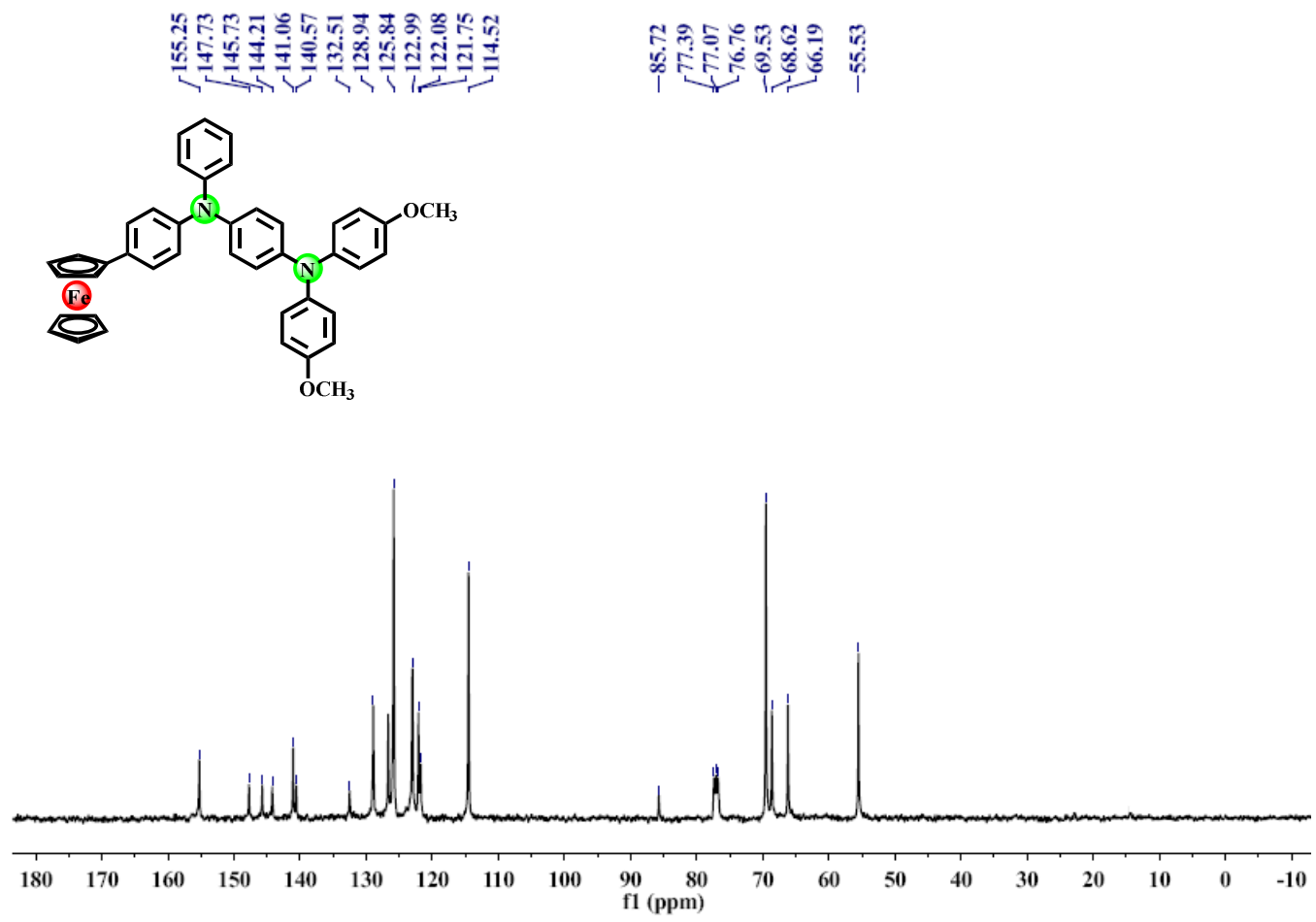

Figure S29. ${ }^{13} \mathrm{C}$ NMR spectrum $\left(100 \mathrm{MHz}, \mathrm{CDCl}_{3}\right)$ of $\mathbf{1 c}$. 
Page 117 of 119

Dalton Transactions

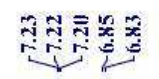

䑶瑟

$\frac{5}{1}$

$\stackrel{\equiv}{\overline{1}}$
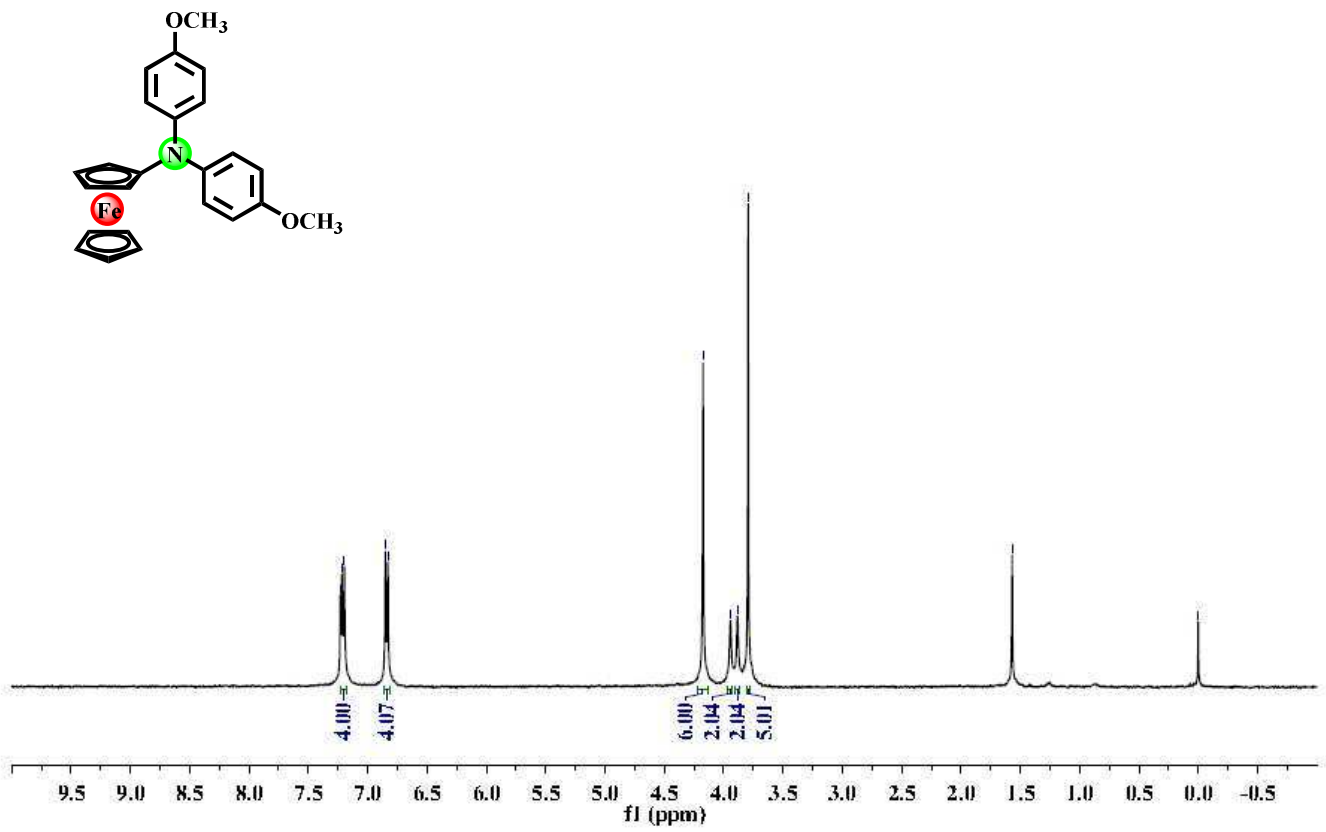

Figure S30. ${ }^{1} \mathrm{H}$ NMR spectrum $\left(400 \mathrm{MHz}, \mathrm{CDCl}_{3}\right)$ of $\mathbf{1 d}$.
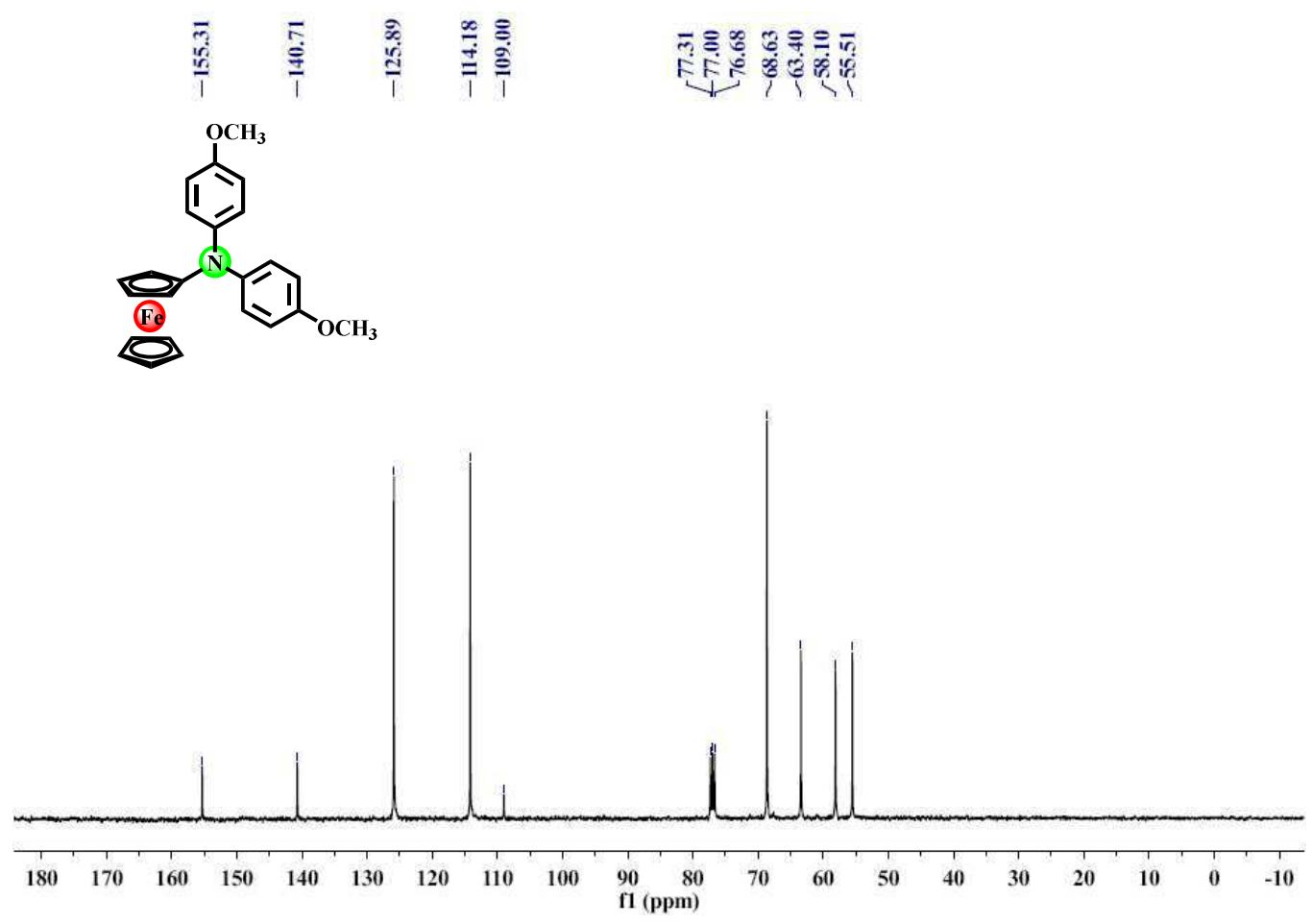

Figure S31. ${ }^{13} \mathrm{C}$ NMR spectrum $\left(100 \mathrm{MHz}, \mathrm{CDCl}_{3}\right)$ of $\mathbf{1 d}$. 


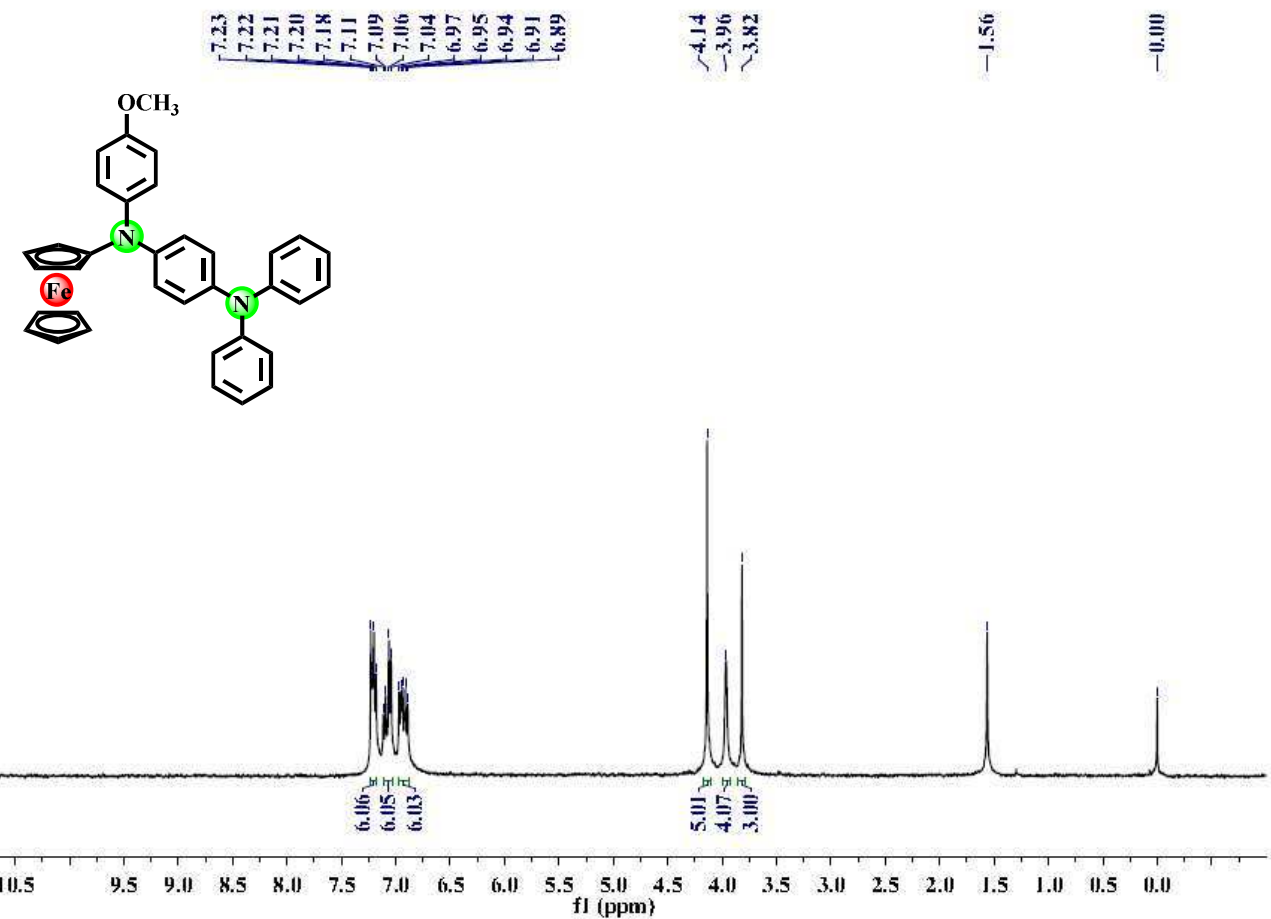

Figure S32. ${ }^{1} \mathrm{H}$ NMR spectrum $\left(400 \mathrm{MHz}, \mathrm{CDCl}_{3}\right)$ of $\mathbf{1 e}$.
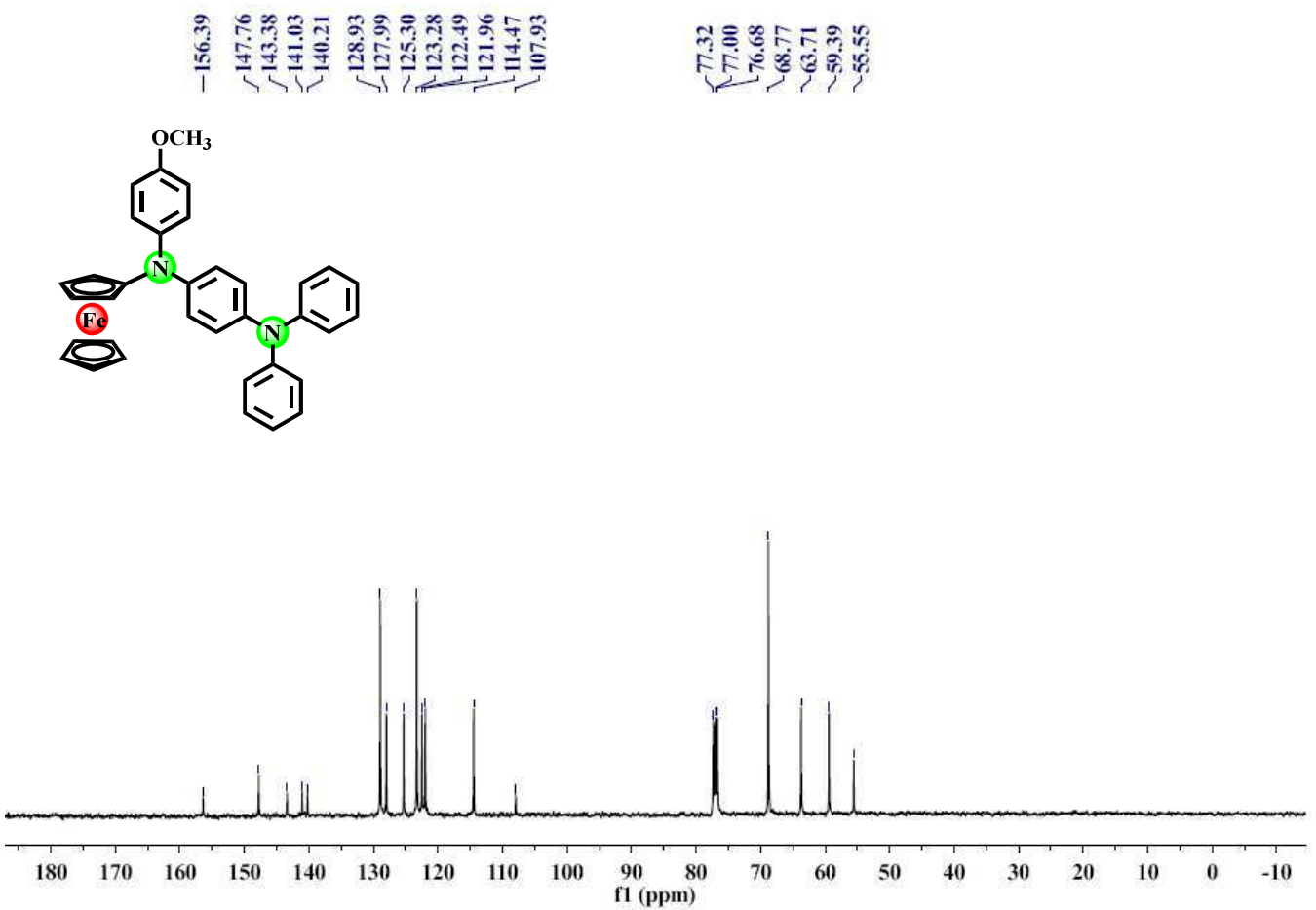

Figure S33. ${ }^{13} \mathrm{C}$ NMR spectrum $\left(100 \mathrm{MHz}, \mathrm{CDCl}_{3}\right)$ of $\mathbf{1 e .}$ 


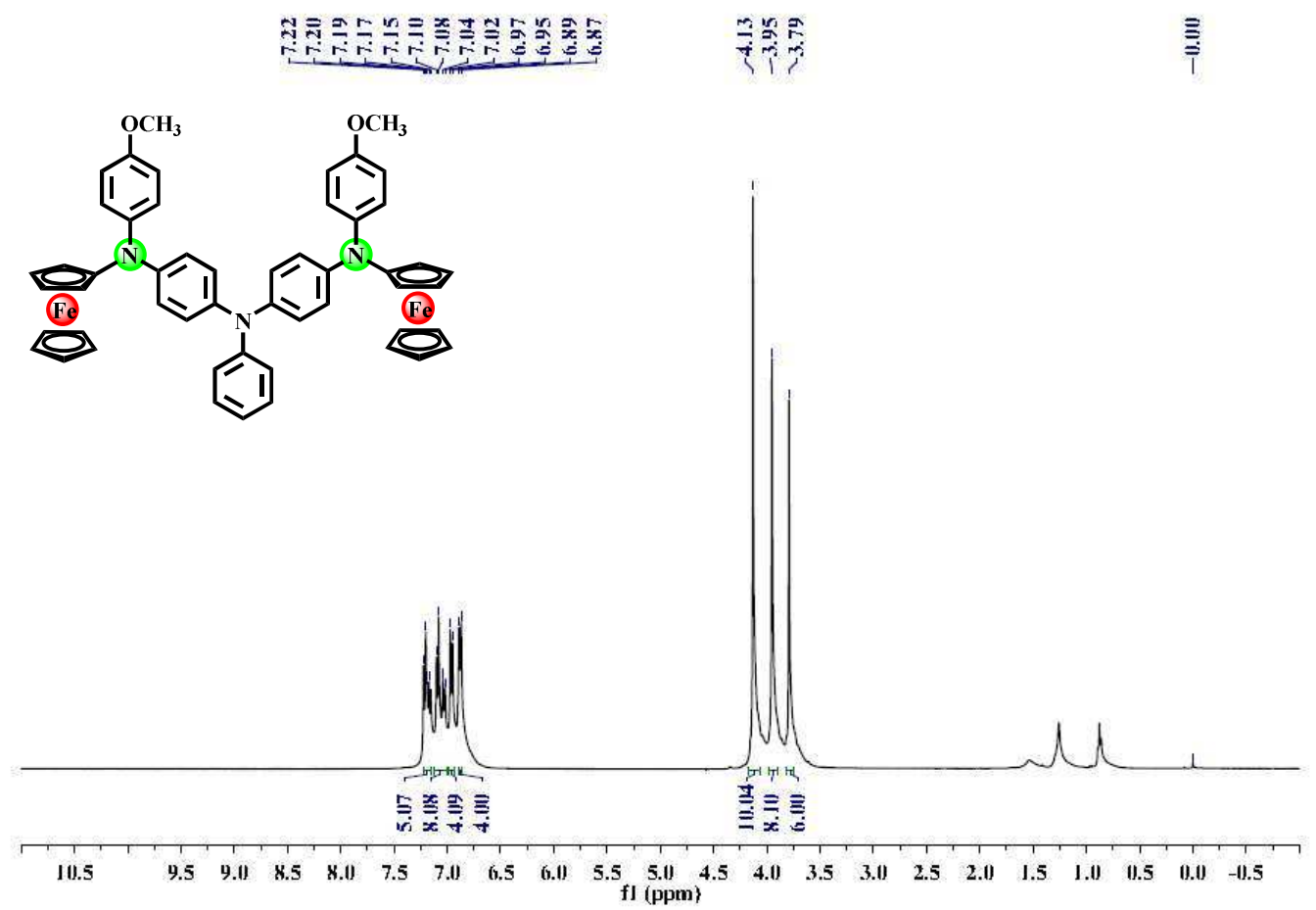

Figure S34. ${ }^{1} \mathrm{H}$ NMR spectrum $\left(400 \mathrm{MHz}, \mathrm{CDCl}_{3}\right)$ of $\mathbf{1 f}$.
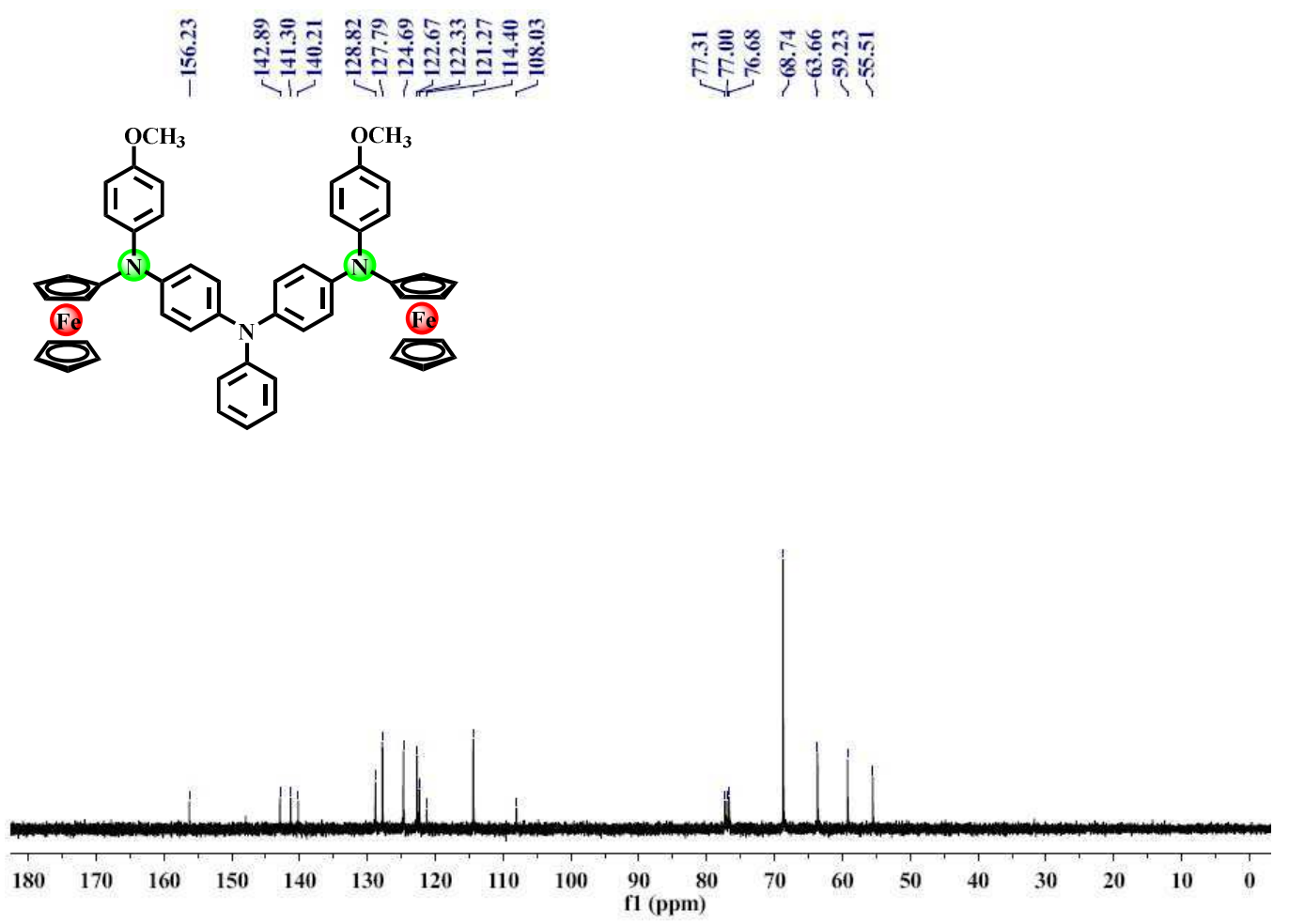

Figure S35. ${ }^{13} \mathrm{C}$ NMR spectrum $\left(100 \mathrm{MHz}, \mathrm{CDCl}_{3}\right)$ of $\mathbf{1 f}$. 